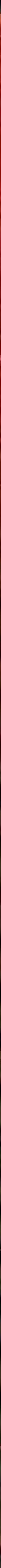




$$
9040861601
$$








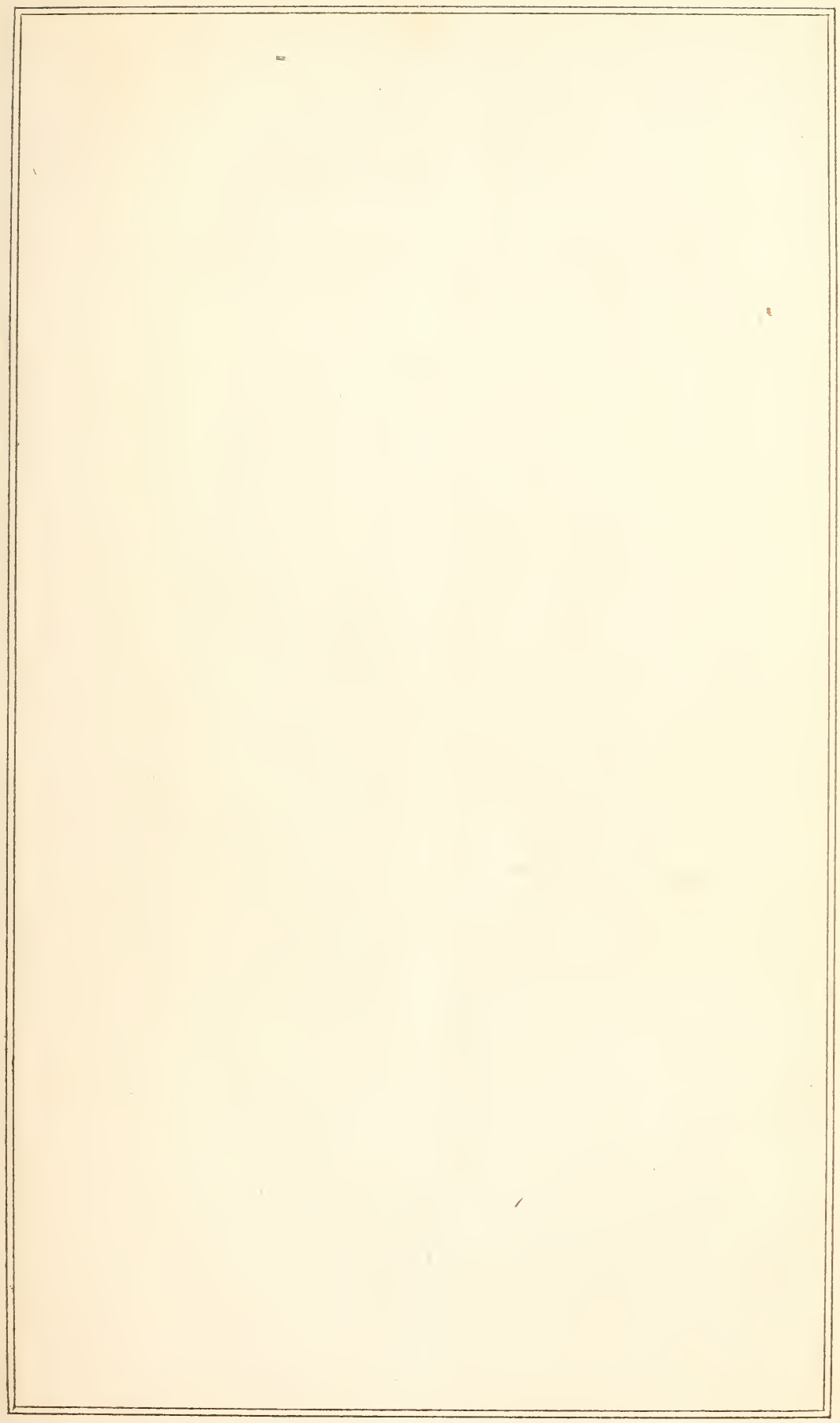




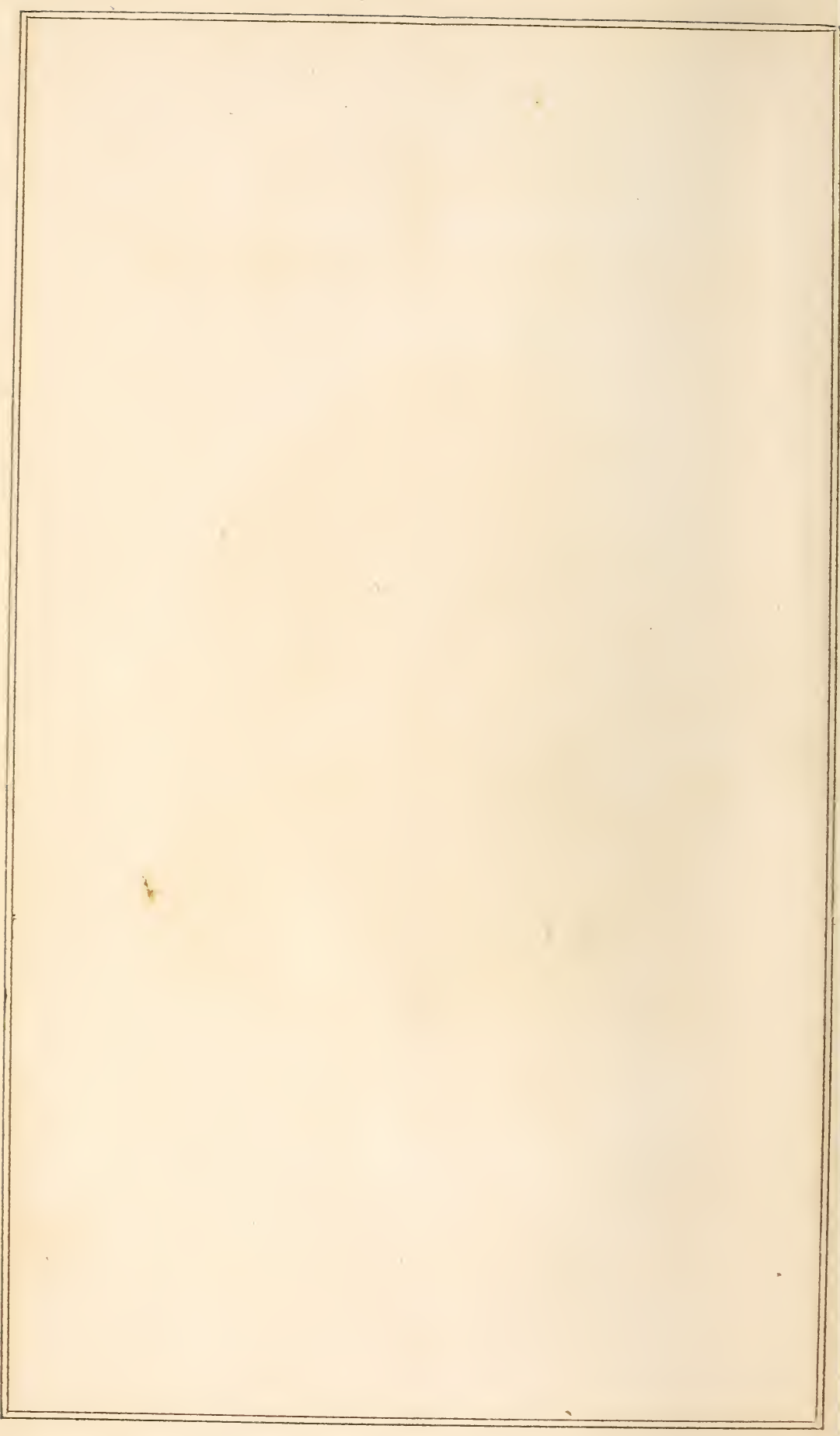




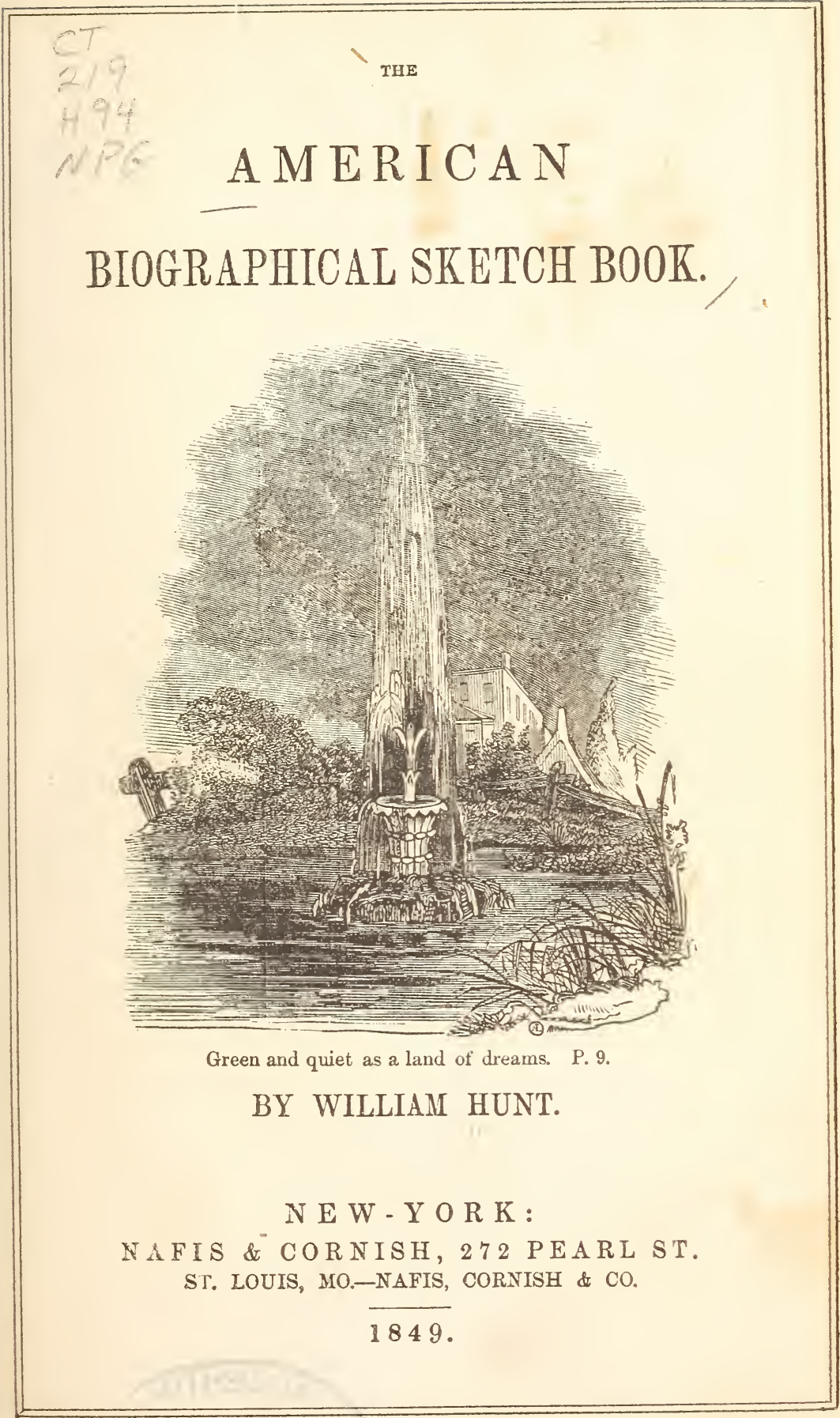


Entered according to Act of Congress, in the year 1848, by WILLIAM HUNT,

in the Clerk's Office for the Northern District of New York. 


\section{ZADOCK PRATT,}

THE FRIEND OF THE MECHANIC,

A N D THE

PATRON OF ALL THAT IS USEFUL,

địt

IS RESPECTFULLY DEDICATED. 


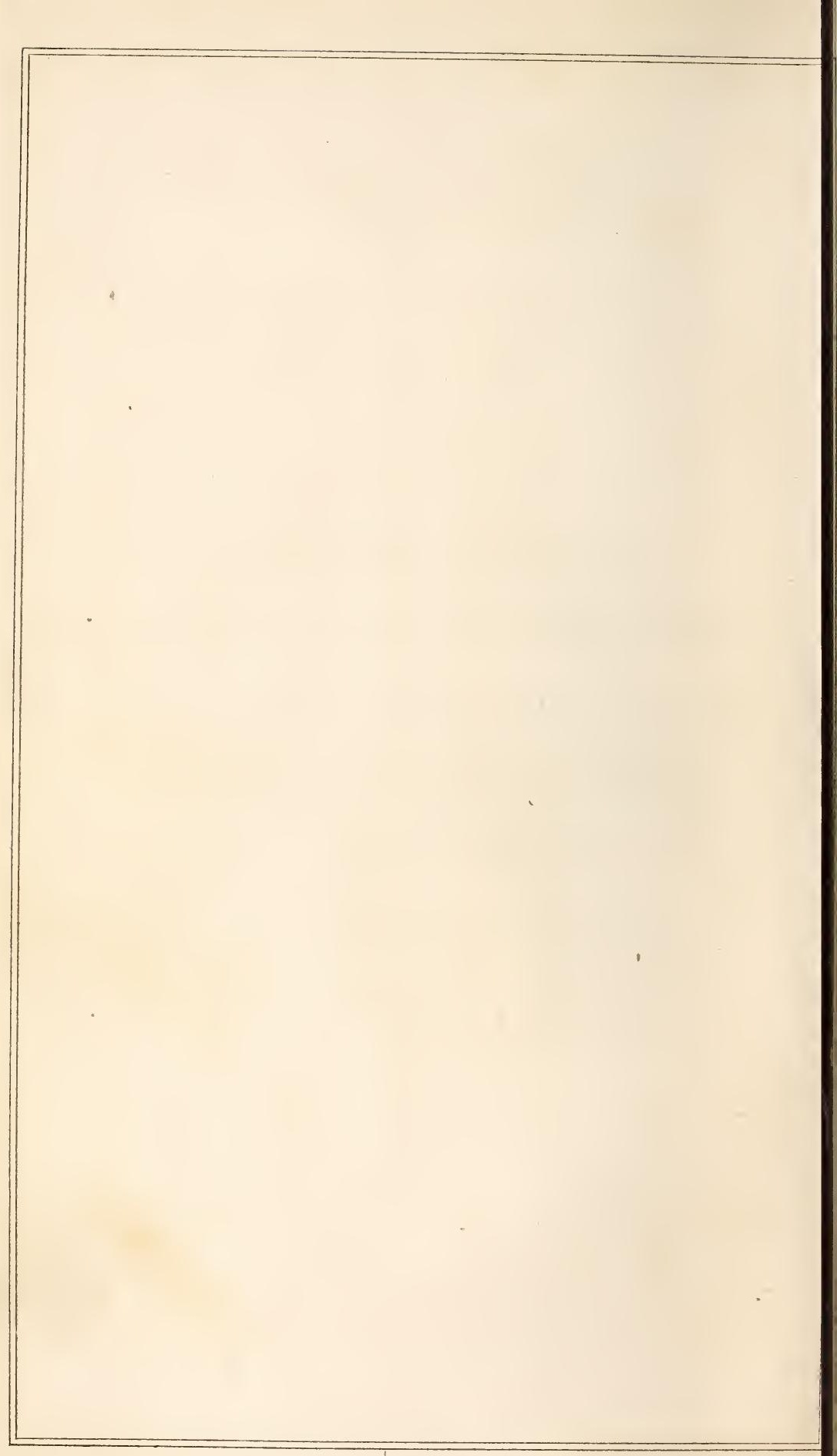




\section{CONTENTS.}

Adams, John Quincy

Allen, Stephen . . . . . . 210

Angel, William G. . . . 86

Anthon, Charles . . . . . 141

Astor, John Jacob . . 272

Banvard, John . . . . . . 385

Bailey, Mrs. . . . . . . 253

Bayly, Thomas H. . . . . . 405

Barclay, Anthony . . . . 308

Beck, Theodoric Romeyn . . 122

Beach, Moses Y. . . . . . 289

Beers, Cyrus . . . . . . . . 263

Beers, George D. . . . . . 349

Brooks, Erastus . . . . . 132

Brooks, James . . . . 309

Bryant, William Cullen. . . . 269

Brittan, Samuel B. . . . . 270

Burritt, Elihu . . . . . 39

Butler, Benjamin Franklin . 208

Burke, Edmund . . . . . 211

Bush, George . . . . . . 263

Buel, Jesse . . . . . . . . 311

Bullard, Otis A. . . . . 344

Cambreleng, C. C. . . . . . 276

Campbell, William W. . . 108

Carlin, John . . . . . . . 352

Cass, Lewis . . . . . 408

Clifford, Nathan . . . . . 127

Clay, Cassius M. . . . . . 355

Clay, Henry . . . . . . . .

Cooper, James Fennimore . 293

Conner, James . . . . . . . 897

Croswell, Edwin . . . . . 285

Danforth, M. J. . . . . . . 347

Dean, Amos . . . . . 168

Delavan, Edward C. . . . . . 83
PAGE.

Dewey, Orville . . . . 300

Edmonds, John W. . . . 340

Evans, Oliver . . . . . 406

Fish, Preserved . . . . . 197

Fisher, Alansun. . . . . . 401

Folger, Walter . . . . . 67

Folsom, George . . . . 251

French, Benjamin B. . . . . 320

Francis, John W. . . . . . . 125

Gallatin, Albert . . . . . 134

Gallatin, James . . . . 138

Gales, Joseph . . . . . . 337

Gordon, Samuel . . . . 159

Greeley, Horace . . . . . 281

Gridley, Abraham . . . . 219

Grinnell, Zelotis . . . . . 266

Griffin, Orrin . . . . . . 303

Harper, James . . . . 56

Harris, Jra . . . . . . . 91

Hale, David . . . . . 296

Hall, Samuel H. P. . . . . 151

Hamilton, Mrs. Alexander . 326

Hathaway, Charles . . . . 130

Hoffman, Ogden . . . . . 195

Hone, Philip . . . . . . . 93

Howard, Leland . . . . . . 233

Howard, Calvin . . . . . 238

Holmes, Isaac E. . . . . . 400

Hughes, John . . . . . 126

Hunt, Freeman . . . . . 174

Irving, Washington . . . . 188

Jefferson, Thomas . . . . 348

Jennings, Chester . . . . . 317

Johnson, Richard M. . . . .408 
Ritchie, Thomas Judson, Mrs. Emily . . . . . 202

Kemble, Governeur . . . . 89

Kent, James ․ . . . 340

Kettell, Thomas Prentice . . . 166

Knapp, Shepherd . . . . .

Knapp, Jacob . . . . . . 328

Lewis, Dixon H. . . . . . 88

Loomis, Arphaxad . . . . 355

Madison, Mrs. . . . . . 339

March, Alden . . . . . .255

Mickle, Andrew H. . . . . 142

Morris, Robert H. . . . . . . 214

Morris, George P. . . . . 102

Morse, Samuel F. B. . . . . 179

Mott, Valentine . . . . . 129

Noah, Mordecai M. . . . . 402

Ogden, David B. . . . . . 81

Olcott, Thomas W. . . . . 157

Parker, Amasa J. . . . . 116

Paulding, James K. . . . . . 143

Perry, John L. . . . . . . 336

Pratt, Zadock . . . . . . 9

Purdy, Elijah F. . . . . . . 198

Rathbone, Samuel ․ . . 398

Richards, T. Addison . . . . 403

Ridgway, Jacob . . . . . . 299

Root, Erastus . . . . . . 247

Rowe, Van Rensselaer . . 155

Sanford, Edward . . . . . 140

Sawyer, William . . . 384

Sears, Robert . . . . . 62

Spofford, Paul . . . . . . 252

Southwick, Solomon . . . . 365

Staats, Barent P. . . . . 163

Stanton, Benjamin . . . 200

Street, Alfred B. . . . . . . 97

Story, Joseph . . . . . . 302

Tallmadge, Frederick A. . . 124

Thurburn, Grant . . . . 181

Van Buren, Martin . . . - 49

Van Buren, John . . . . . . 51

Walworth, Reuben Hyde . 68

Ward, Elijah . . . . . . 294

Ward, Aaron . . . . . 144

Warner, Thomas . . . . 190

Watson, Malböne . . . . 313

Webster, Daniel . . . . . 275

Weed, Thurlow . . . . 359

White, Edwin . . . . . . 325

Whiting, James R. . . . . 231

Whitney, Eli . . . . . 407

Willard, Emma . . . . . 224

Woodhull, Caleb S. . . . 367

Wright, Silas . . . . . 172 


\section{PREFACE.}

Andrew Fuller once remarked that "he would rather be like the moon, which, although full of spots and imperfections, lends a useful light to men, than a meteor, with its dazzling but transient glare, exciting only the wonder of mankind." It was in the spirit of this sentiment that we compiled the following pages, embracing brief sketches, for the most part, of the lives of men who, by unwearied perseverance, have triumphed over difficulties. Born in an humble sphere, which precluded the advantages of a liberal education, we resolved, that although unable to write a learned work, we would attempt to produce a useful one. Hence, the fastidious critic who shall search for faults, will be rewarded with an abundant harvest. If, however, this volume shall serve as a hint to those so well able to write a better, a valuable end will have been attained. But, in the absence of such, we flatter ourself that the Biographical Sкетch Book, with all its defects, will not be entirely unacceptable to a discerning public. The "needle," although unpolished, may yet serve to point the way to the "pole;" and if the examples set forth shall cheer but one sufferer, and enable him to wait with patience for the bright dawning of to-morrow, the labor will not have been in vain. 
It is hoped that the work will prove especially interesting to the young, inasmuch as it will furnish numerous illustrations of the fact, that " untiring industry will accomplish wonders;" and that with this for his motto, the poor clerk has become the rich merchant-the plow boy a legislator-the errand boy a minister plenipotentiary-the mechanic has exchanged his hammer for the speaker's mace-and a poor friendless youth has filled with honor the presidential chair.

From the eventful lives of the subjects of these sketches, it will be seen, that as in the inorganic, so in the living and moral world, there is a succession of changes; and that although many of the bright hopes which may have been sent forth to meet the future, have returned, like the dove to the ark, having found no resting place in the weary world; yet, as has been beautifully observed, it is in the darkest thunder cloud that the most brilliant lightning sleeps, and the tear which has flowed even in the anguish of despair, must, by the laws of nature, sooner or later reappear in the rainbow. And as the telescope has resolved the golden mists of the milky way into suns and systems, so one day shall the clouds of our existence be converted into stars. Repeated troubles are sent, not as lightning on the scathed tree, blasting it yet more, but as the strokes of the sculptor on the marble block, hewing it to the image of life and moral loveliness. $\mathrm{HE}_{\mathrm{E}}$ at whose voice primeval darkness vanished, and

The startled seas and mountains cold, Shone forth all bright in blue and gold, And cried, 'Tis day, 'tis day!

does not, in the course of His providence, permit affliction to continue but for a season, when he hangs out his "bow in the cloud." "Sweet are the uses of adversity." How many transcendent talents would have been lost to the world, but for reverses. 
Rills o'er rocky beds are borne,

Ere they gush in whiteness:

Pebbles are wave-chased, and worn,

Ere they show their brightness.

Sweelest gleam the morning flowers,

When in tears they waken;

Earth enjoys refreshing shotvers,

When the boughs are shaken.

It will also be seen, that although there are many thorns in the pathway of life, yet there are "corals, and pearls, and roses," which may be gathered by those whose hearts are attuned aright.

Earth is not all fair, yet it is not all gloom.

And the voice of the grateful will tell,

That He, who allotted Pain, Death, and the Tomb,

Gave Hope, Health, and the Bridal as well.

O hopelessly rare is the portion that's ours,

And strange is the path that we take,

If there spring not beside us a few precious flowers,

To soften tive thorn and the brake.

The narratives will also furnish evidence of the fact, that most of those who have successfully battled with difficulties, are married men. Indeed, it will readily be granted, that as to efficiency in life, the bachelor cannot be compared with the married man. To provide for a wife. and children is one of the greatest of all possible spurs to exertion. Many a man, says Cobbett, naturally prone to idleness, has become active and industrious, when he saw children growing up about him; and many a dull sluggard has become a bright man when roused to exertion by his love. To a young man, especially, nothing is so important as an attachment to some virtuous and amiable woman. whose image may occupy his heart, and guard it from the 
pollutior which besets it on all sides. With justice ought we to lay at her feet the laurels which, without her, would never have been gained. It is her image that strings the lyre of the poet, that animates the voice of the orator, and which urges on the hero to deeds of noble daring; and whatever may be the harsher feelings that life may develope, there is no one, however callous and constrained he may have become, whose brow will not grow pensive at the memory of FIRST LOVE.

"Bless thee, O woman! for dark were this world without thee; cold and wintry without the sunlight of thy smiles; dry and withering even, without thy tears; harsh and perfumeless without the incense of thy sighs; dull and echoless without the music of thy voice!" 
, 


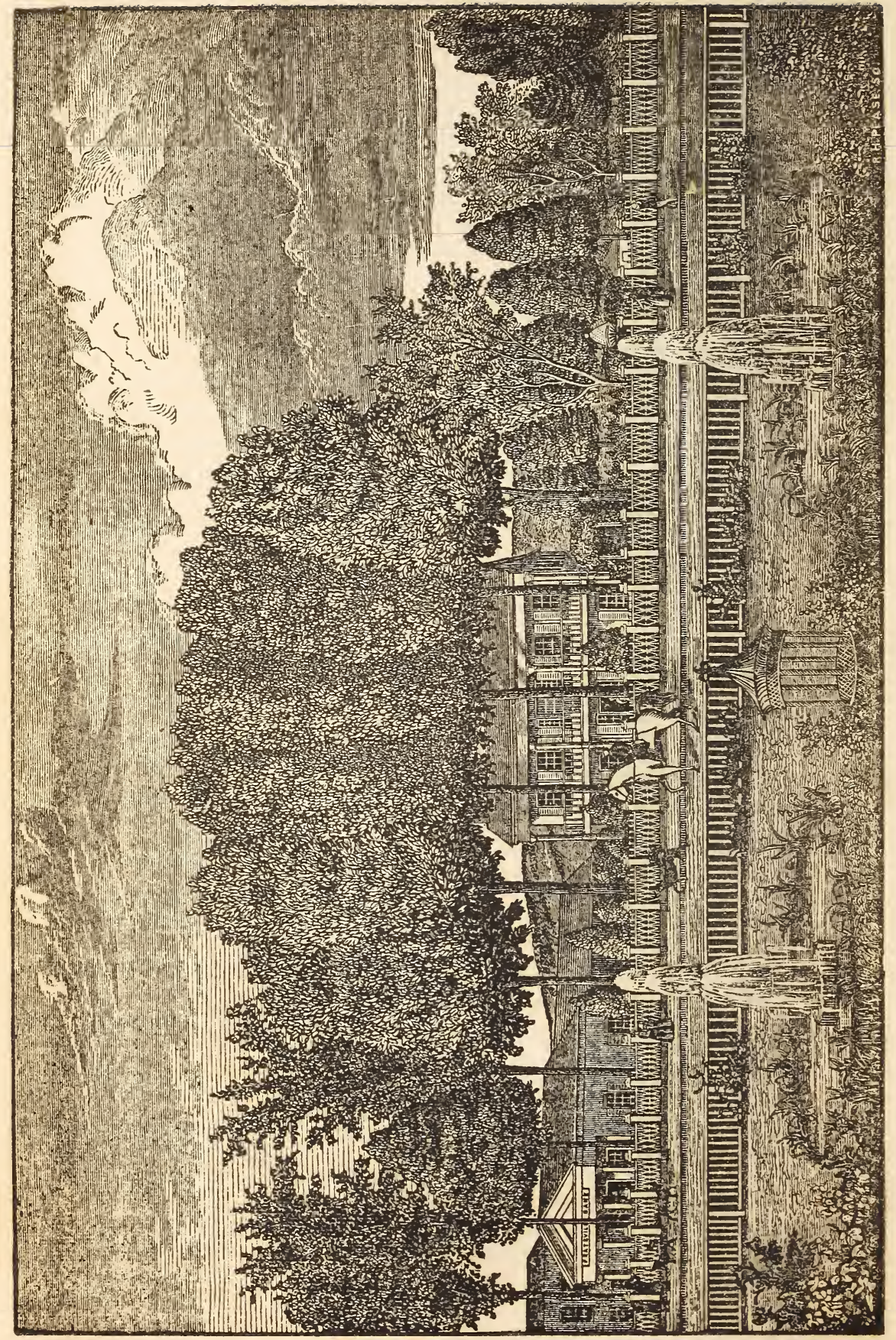




\section{A M E R I C A N \\ BIOGRAPHICAL SKETCII BOOK.}

\section{ZADOCK PRATT.}

Ho! all who labor, all who strive!

Ve wield a lofty power;

Do with your might, do with your strength,

Fill every golden hour.

The glorious privilege то Do

Is man's most noble dower.

Autumn was upon us with its "dyed garments of glory," and low purple clouds hung in festoons around the steeps, when by the crimson light of a setting sun, which transmuted every feature of the landscape into living gold, the writer first caught a glimpse of the beautiful village of Prattsville, as it lay nestled among the mountains, with its waterfalls and fountains, elegant dwellings, churches and burial grounds, "green and quiet as a land of dreams." The extreme neatness of the place, and the good taste everywhere apparent, naturally led to inquiries as to the origin of this "gem of the wilderness." With what success these investigations have been attended, will appear from the following notice of the worthy founder.

The great interest manifested in the remarkable career of the Hon. Zadock Pratt, and the strong desire of his numerous friends in all parts of the country, to obtain additional memorials of his life and character, have induced the writer to devote a 
much larger space to this gentleman than was originally intended. The fame of his industry and perseverance, and of his extensive and successful enterprises, is widely spread; and thousands of intelligent young men who have read of his wealth and liberality, are anxious to obtain further particulars of his life, that they may imitate his example. The numerous individuals whom he has aided, especially those of the laboring classes, and the various communities and societies who have experienced the beneficial effects of his philanthropic spirit, will welcome this tribute to his character and public services. The compiler has not aimed at display, but has endeavored to give a succinct and connected narrative of an unassuming and patriotic citizen, who, by the force of his native genius, has risen from obscurity to distinction, from poverty to wealth, and from the workshop to the halls of Congress; and who, in whatever situation he has been, whether as the humble laborious tanner, the opulent banker, or the industrious and fearless legislator, has ever maintained the character of a straight forward, honest man. His life administers a strong rebuke to the many young persons of romantic temperament, who look forward to the attainment of the highest ends of human life without dreaming of the price that must be paid for them. It affords an additional illustration of the truth, that it is impossible "to get something for nothing," and that the Divine declaration "thou shalt eat thy bread by the sweat of thy brow" has lost none of its force.

Man must labor; nought is sleeping In the dimmest, brightest zone,

From the worm of painful creeping

To the seraph on the throne.

From the brief but interesting memoir recently published in the Democratic Review, it appears 
that Zadock Pratt was born on the 30th of October, 1790, at Stephentown, Rensselaer county, New York, and that his family is descended from the noble band of pilgrims, who first broke ground on the shores of New England-the first persons of the name in this country being Joshua and Phineas Pratt, who came over in the autumn of 1623. Ephraim, a grandson of Joshua Pratt, lived to the great age of 116 years, and died at East Sudbury, Massachusetts, in May, 1804. Phineas Pratt removed from Plymouth to Charleston. John, another of the family, came over in 1633, in company with the celebrated Puritan divines, John Cotton, and Thomas Hooker; and when the church, which had been formed at Newtown, Massachusetts, by the latter, concluded to remove to Connecticut, Mr. Pratt was one of their number. They commenced their exodus in the month of June, 1636. It was to be through a dreary and trackless wilderness of more than a hundred miles. They had no guide but their compass; no covering but the heavens. There were about one hundred persons, men, women, and children. They drove along with them one hundred and sixty head of cattle, subsisting on their march through the wilderness, upon the wild fruits which they found, and the milk of their cows. The females who were ill, or too feeble to endure the journey on foot, were borne in litters upon the shoulders of the young athletic men. The whole journey occupied nearly a fortnight, during which they had no shelter but such as they formed of the branches of the trees. From the worthy Puritan here mentioned, the families of Pratt, in Connecticut, are mostly descended.

The father of the principal subject of this notice (Zadock Pratt, senior,) was a native of Saybrook, Connecticut; he was a tanner and shoemaker, and when the revolutionary ${ }_{6}$ war broke out, he shouldered his musket, and repaired to his country's standard 
He was engaged in several hard fought battleswas twice taken prisoner, and suffered much on board the prison ships at New York. After the close of the war, he removed to the state of New York, and died at Lexington, Greene county, in 1829 , at the age of seventy-four.

Mrs. Pratt survived her husband but about three years. She died in 1832, in the seventy-fourth year of her age. She was a woman of superior intellect and of high moral worth; and her son, even at this late period, never speaks of her without strong emotion, as to the excellent principles instilled by her into his youthful mind, he justly attributes his subsequent success.

Zadock Pratt the younger, had no education other than that afforded by a common school. Out of school hours he worked hard to pay his board, and at a very early period he had to encounter many difficulties. The first money he ever earned was by gathering huckleberries, which he sold for a few cents per quart. From this humble beginning he went on, adding to his little store as opportunities permitted; and being well aware that industry without frugality is comparatively useless, he husbanded all he earned with unceasing care. Pursuing this course with steadiness and resolution, and occupying all his leisure hours in making leather mittens and whip lashes, for which he found a ready market, he soon became possessed of thirty dollars, a large sum for a working boy, and which he looked upon as the seed of future riches. Having early been taught the value of economy, he found as great a pleasure in saving his little earnings as did his thoughtless companions in spending theirs. While they earned only for present gratification, he was looking forward to the period when these trifles would enable him to lay the foundation of a prosperous business. He was subsequently apprenticed to a saddler, named Luther Hayes, of Durham 
Greene county. Here he frequently worked until after nine o'clock at night, and very soon, as a reward for his great industry, received from his employer the materials for a saddle, which with the same persevering toil, while the other apprentices slept, he succeeded in finishing before the close of the first season. He then exchanged the saddle for, a watch, the first he ever possessed.

Having completed the term of his apprenticeship, he for some time worked as a journeyman saddler for his father and brother at Lexington Heights, for two dollars and fifty cents per week, and then commenced business for himself. His shop was in one end of an old "bark house," separated from the mill by a slight partition only, and through which whenever the door was opened, the bark dust entered in clouds. Here he labored from fifteen to sixteen hours per day, kept an accurate account of all his business operations, and yearly took a complete inventory of his little property, a custom which he has ever since continued. Here he bought the first one horse waggon that had ever been seen in that wild country; and not having at hand the assortment of articles required in exchange, he sat up all one night and made a saddle, which supplied the deficiency. This judicious system placed him at once on the road to fortune. The first year, his profits were over five hundred dollars: the next year still more, and they continued to increase. Feeling now quite rich, he built a little red shop, where in the following year his work amounted to twelve hundred dollars, and the next year to fourteen hundred dollars. His grand secret was "living on little." His surplus earnings were devoted to the purchase of an assortment of goods with which he furnished one end of his shop, thus turning it into a country store. He still carried on his work at the other end, and slept under the counter upon the rags which the thrifty housewives of the neigh 
borhood exchanged with him for goods. It was often convenient for him to take produce in the way of trade; and in the season for it, he received a great deal of butter, most of which was packed down by him after nine o'clock at night. On one occasion, having taken a quantity of produce to New York, he arrived at Catskill on his return, between four and five o'clock P. M., and walked home, a distance of thirty miles, the same night. Fearless and hardy, he could, when circumstances required, pass the whole night in the woods with impunity, and say, with the bold ranger of Sherwood,

My fortress is the good green wood,

My shade the "hemlock" tree;

And [ know the forest round me

As sailors know the sea.

Among the rules which it may be said formed the business creed of his life, were the trite and homely, but expressive maxims, which he used to post up in his workshop and store, and mark upon his account books-"Do one thing at a time""Be just and fear not"- "Mind your own business." Blessed with an excellent constitution, and an iron frame; with an indomitable resolution and perseverance, which no difficulty could daunt, no exertion weary-labor was to him the salt of his existence, seasoning his daily bread, and stimulating him to further and higher exertions. From this time his course has been uniformly onward and upward.

In $1815 \mathrm{Mr}$. Pratt sold his store, just in time to escape the commercial revulsion, which shortly afterward followed, and which ruined the firm which had purchased from him. He continued, however, to work at his trade, and also entered into a partnership with his brothers, in the business of tanning. The eldest, who had a wife and four 
children, boarded the others; and all the expenses of the joint family, including doctor's bills and schooling, were paid out of the partnership funds. $O$ that the bachelors of the present day were equally just!

During the last war with England, Mr. Pratt, inheriting the patriotic spirit of his father, rallied with others in his vicinity, to the defence of New York, and the company to which he was attached made him their steward. Then, as now, there was corruption in office, and which needed bold, honest men to expose it. In the disbursement of the public money, great frauds were perpetrated by the commissioners and paymasters of the army. Mr. Pratt soon discovered that not a company received the full amount of rations provided by law. So far as his company was concerned, he was determined to check the iniquity at once. Accordingly, on his next visit to the commissary, he took with him a few choice men, on whom he could rely in case of difficulty. After receiving the usual allowance of provisions, he demanded numerous other articles to complete the rations which he was entitled to draw. The commissary was utterly astounded at such assurance, and his astonishment was fully equal to that of the tyrants of the poorhouse, when Oliver Twist, in the simplicity of his heart presented his little porringer and "asked for more."

"I'll tell you what!" thundered the commissary, with a scowl; "take what you have and be off!"

But he had to deal with a man not accustomed to "be off" without justice, and who was firm as a piece of his well-tanned sole leather.

"All or none!" said Mr. Pratt; "no cheating soldiers, sir!"

The commissary trembled with rage, and if looks could have done it, the subject of this memoir 
would long ago have slept quietly in his mother earth-

At his head a green grass turf,

And at his feet a stone.

But finally the peculating officer concluded to do justice, and the proper supply continued to be furnished as long as Mr. Pratt was steward, although his successor was unable to obtain it.

In $1821 \mathrm{Mr}$. Pratt received a commission as captain in the 5th regiment of artillery, which in 1823 he resigned, on receiving the appointment of colonel in the 116th regiment of infantry of the state of New York. In this position he was prompt, energetic, and liberal-a good disciplinarian, and contributed much to the improvement of the corps to which he was attached. When in command of his company, he furnished a uniform for the whole, and being in want of a suitable field piece, he applied to the governor, and succeeded in obtaining one of the twelve remaining to be disposed of, though there were thirty applicants before him. He proposed to Governor Clinton, that he would mount the cannon at his own expense. "No, no, young man," said the governor, "you have already done enough without that." He provided the regiment under his command with all their music, at an expense of some $\$ 250$.

In 1826 he resigned this latter commission, having no great predilection for a military life, although whilst engaged in it he displayed his usual energy, doing nothing by halves.

At the close of his military career, in order to gratify his regiment, he gave one hundred and twentyfive pounds of powder for the purpose of re-enacting the memorable battle of Lodi, he himself taking an active part in it. The place selected was a bridge. at Windham, admirably calculated for the manouvres. The "battle" went off with great eclat, 
to the great satisfaction of the soldiers, and the delight of the thousands of spectators who had assembled from all parts of the county. On another occasion, when a sham battle was fought at Lexington Helghts, Col. Pratt ordered a captain of infantry to march round the meeting house and open a fire upon the artillery.

"But, Colonel," said the latter, "shall I not be in danger?"

"O no," replied the Colonel, "if you are, you can jump up behind me."

With this assurance of safety, the captain drew his sword, sprang like a tiger from his jungle, and giving the word to his men, a more murderous fire was opened upon the unfortunate artillery, than has ever been recorded in the annals of "infantry." Nothing but the most devoted patriotism could have enabled the "enemy" to withstand it.

In the winter of $1839, \mathrm{Col}$. Pratt and his elder brother, planned an adventure to Canada, of which the Colonel took charge. He was accompanied by three of his neighbors, with an equal number of teams, laden with leather, harness, and dried apples. They went to Kingston, and from thence to Bellville, where they remained until spring. While at Kingston, their landlord picked a quarrel with them, and one of the party, who had drank too much, was determined to fight him. A crowd of town loafers, who had gathered round, showed by their conduct that the first blow would be the signal for a general attack, in which case the small company of Americans would have been overpowered by numbers, and plundered of their goods, besides risking their lives. Col. Pratt saw at once the danger of their situation, and, entrusting their belligerent comrade with the trunk which contained all their money in silver, busied himself in getting the teams ready for a start. As was anticipated, the trunk of specie kept the peace, for the 
holder could not fight without letting it go, which he dared not do, lest it should be stolen. By this quick sighted manouvre of the Colonel, the threatened collision was prevented and the property secured. When will nations remember that they cannot fight without endangering the safety of the "trunk of specie?"

After disposing of his goods at Bellville, Colonel Pratt went with a couple of traders to Rice Lake, for the purpose of buying furs from the Indians. His companions took the usual Yankee notions, whilst he carried a knapsack well stored with bread, butter, and salted raw pork, a mitten full of silver dollars, and a bag of gold, sewed in a pocket inside his shirt, together with $\$ 2000$ in bills.

"At noon," said he in a letter to a friend, "we mounted on an old oak of enormous size, which had been lying there for many years, and which seemed like a patriarch of the forest. I made a dinner on raw pork, and bread and butter, and a good dinner it was, after having traveled through the snow since very early in the morning. After dinner we went due north, but towards evening we lost our way, and wandered about till night. We now struck up a fire in an old maple top, and supped upon a piece of pork, cooked upon the end of a stick, and washed down with cold tea. $\mathrm{W}^{\mathrm{T}} \mathrm{e}$ next looked about for a lodging. Above was a clear cold sky, beneath was the clean white snow. I would willingly have given some of my gold eagles for a barn to sleep in. Making a virtue of necessity, I got together some pieces of bark, and laid them down upon the snow. I next broke up some bunches of maple twigs, (as there were none of my favorite hemlock boughs to keep off the wind and cold,) and laid them round the bark. Then taking my silver dollars for a pillow, drawing on my fur cap, and pulling the bearskin cape of my coat over my head, I went to sleep, and slept 
soundly until morning, suffering no inconvenience whatever. The next day we pursued our journey, wandering first one way and then another, until about one in the afternoon, when we discovered the Indian track, and the same night reached a hut. The squaw was making sugar, while John Snake, the Indian, was off after beaver. My companions, however, succeeded in purchasing some skins of the squaw. Their keg of whiskey was hid away, and they took only a small quantity with them, which was largely diluted with water. This they said was a necessary practice, for the squaw would sell but a few of the skins at a time, and required to be treated at each bargain; so that notwithstanding the weakness of the liquor, she soon became very drunk. This trading was all they were able to accomplish at that place, for when John Snake returned, having been unsuccessful in his hunt, he brought no furs."

This expedition, although upon the whole successful, effectually cured Col. Pratt of any desire for further trade with the Indians. On his return he came by the way of Utica, having on his old bearskin great coat, the remainder of his apparel being equally shabby, and very much worn. His money, in gold and silver, was enclosed in a bag, and made up like a knapsack. On the arrival of the stage at the principal hotel in Albany, the landlord came out, and to the passengers generally, was extremely polite, asking them "how they did?""what he could do for them?" - "what they would have?" etc. But when our rough looking traveler alighted, "mine host" eyed him askance. There was no "how d'ye do?" for a poorly clad customer. So Col. Pratt took his bag of money under his arm, and, uninvited, proceeded to the bar room, whilst the landlord was waiting upon the gentlemen into the parlor. On his reäppearance, the Colonel inquired if he could be accommodated with lodging, 
as he was desirous of going down the river by the boat in the morning.

"I suppose you can," was the gruff reply, the speaker no doubt wondering at the presumption of such a meanly dressed man, in thus daring to obtrude himself among "his betters," at the "first hotel," or perhaps thinking of the wise regulations of a certain eating house in London, where the knives and forks are chained to the table.

"Can I have supper?" was the next question.

In a low growl, the answer came, "I suppose you can."

Col. Pratt having previously placed his knapsack in the bar, called the attention of the landlord to it, and requested that it might be placed out of sight.

"Where is it, and what is it?" was the snappish reply.

This was very soon explained, and the landlord, on lifting the heavy bag of money, became suddenly transformed into Chesterfield himself, and so burdened the Colonel with his politeness, that the next morning he found it very difficult to get away. This anecdote has been frequently related by the Colonel, with perfect good feeling toward the landlord, as he did what many others, who believe that "the coat makes the man," would have done under similar circumstances. "But," says the Colonel, " it taught me that if I had money I had friends."

Arriving at Catskill, on his way home, he was asked by Mr. Hall, the cashier of the bank, if he had heard from home. "No," was the reply.

"Your tannery is burnt to the ground," said the former.

This was a heavy loss, and one which would have effectually discouraged a less energetic man; but Col. Pratt observed, "Well, thank God, with industry, economy, and good health, we can build another;" which he and his brother accordingly did, on a much more approved plan. How many 


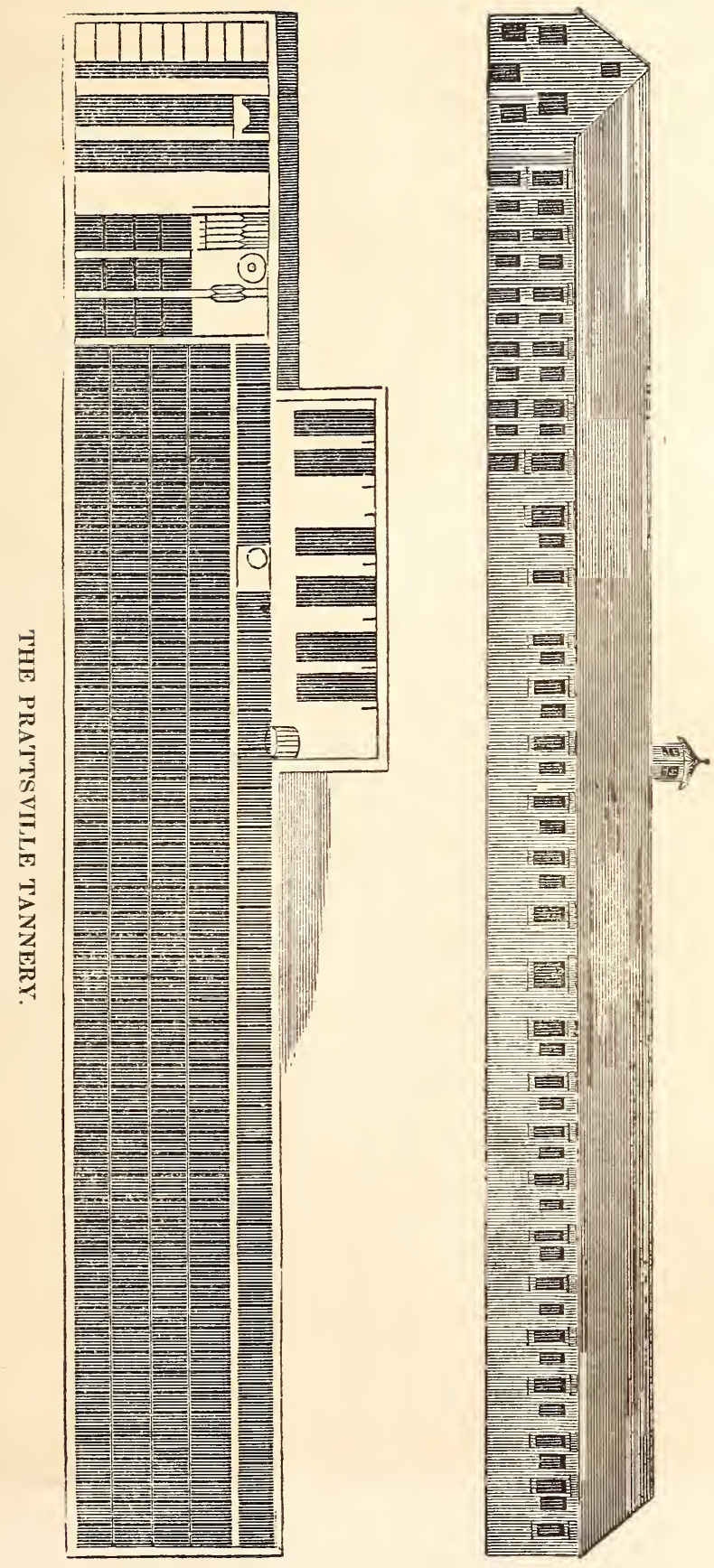

would have sat down in despair, saying, "it is of no use striving for I am born to bad luck" - instead of adopting the motto which solves the problem of heroes-_"Press on."

Col. Pratt, in connection with his brother, carried on his business at Lexington, until 1824, when, determining upon seeking a larger field of operations in manufacturing, he closed his business at that place, purchased the tract and water power now included in the village which bears his name, and commenced his operations. The forest on either hand, to the very tops of mountains, was a dense growth of hemlock, adapted to his purposes; communication was easy with New York, and he at once saw that here was the spot for him to establish a mammoth tannery. He lost no time in conmencing operations, and his labors were crowned with the most complete success. His establishment soon gave employment in various ways to more than 200 men, to all of whom he gave encouragement to settle around him. His tannery was 500 feet long, containing over 300 vats, or about 46,000 cubic feet of room for tanning operations; requiring a consumption annually of 1,500 cords of wood, and 6,000 cords of hemlock bark, in the manufacture of 60,000 sides of sole leather, which he annually sent to market-or, say more than a million of sides in the last twenty years-employing a capital of over $\$ 250,000$ a year, without a single litigated lawsuit.

The plan he adopted to avoid litigation, deserves general imitation. It was as follows:

For many years it has been the practice of the best newspapers of the principal cities to publish brief notices of the decisions of the courts. These notices Col. Pratt has always been careful to preserve, and he has a large book filled with them, and so arranged that he can easily refer to them. By daily reading, he thus acquired a sufficient 
knowledge of the law, to enable him to steer clear of the shoals and quicksands upon which so many have been wrecked. From these memoranda he discovered one fact, which if duly considered, would tend much to deter young men from encountering the glorious uncertainty of the law. It is "that of the whole number of reported cases which had been affirmed or reversed by the Supreme Court of the United States, up to 1830, four hundred and twenty-five had been affirmed, and three hundred and twenty-nine reversed-the affirmations being little more than one-half.

As the tide of prosperous business poured in upon him, his friends and neighbors also flourished. The town was rapidly settled and improved; streets were laid out, and ornamental trees planted by his own hands; schools were established, churches built, and houses and stores multiplied, until the village has become one of the most pleasant and flourishing settlements in the region of the Catskills. More than one hundred of the houses were erected by Col. Pratt himself; and his munificence is seen in all the churches and public buildings in the place, of which more than one-third the cost was defrayed from his own pocket.

In the disposal of his lands he never speculated upon the wants of the poor, having always sold his spare lots at a reasonable price; and he has furnished many with a house which their unaided exertions could never have procured. He was, however, always careful to dispose of no lot, but on the express condition, that no ardent spirits should be sold on the premises.

The excellent quality of the manufacture of Col. Pratt-a result which he attained by the adoption of every useful improvement in the art of tanning leather-secured him a never failing market. In 1337, he and his partner (Col. Watson) received the Silver Medal, of the New York Institute, for the 



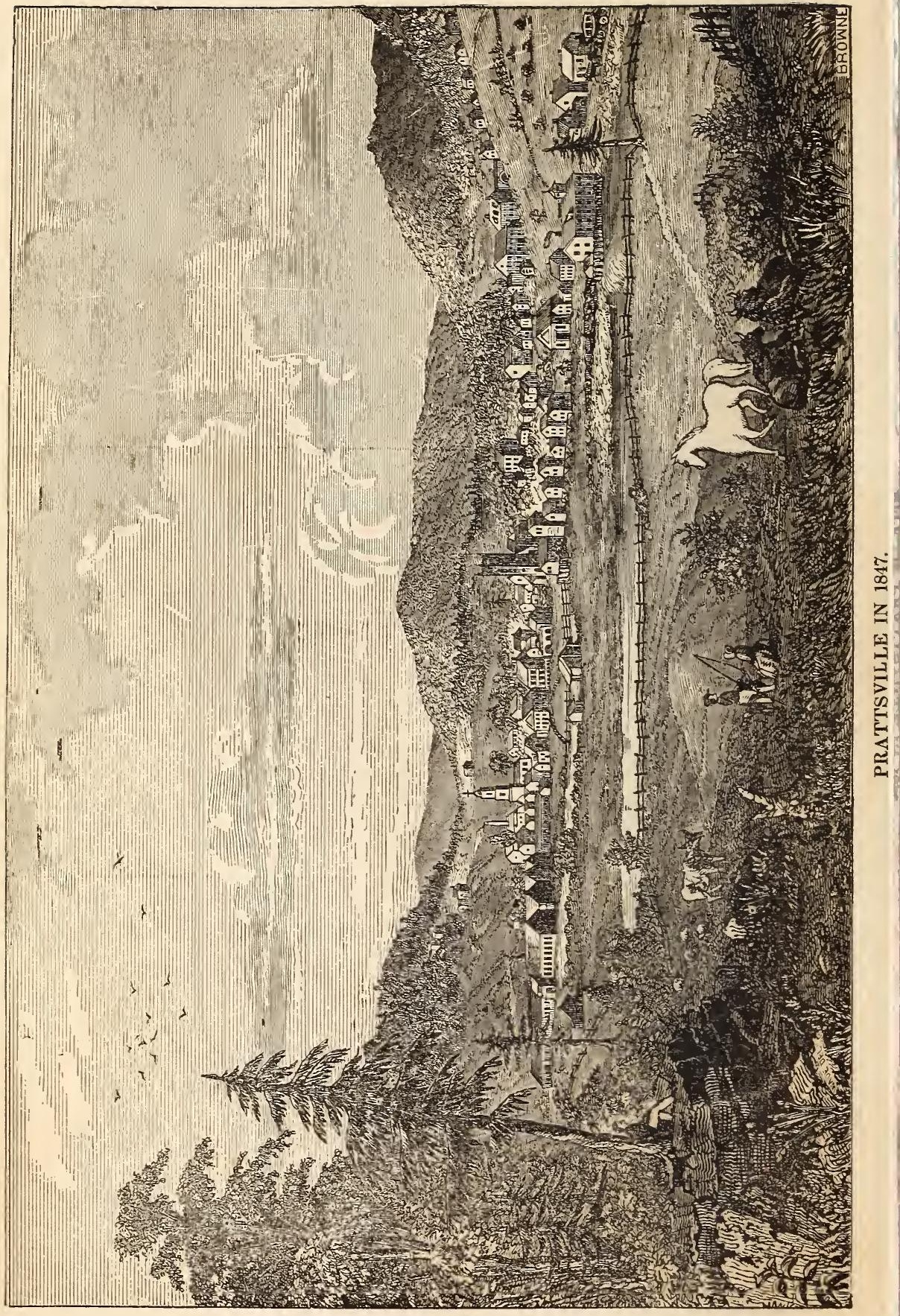



best specimen of hemlock tanned sole leather-the first medal ever awarded for that manufacture. In 1839, he was elected a member of the American Institute; and in 1845, at the New York State Fair, he was awarded the first premium in a Diploma. He glories in the name of a mechanic, and is proud to acknowledge the quiet and laborious occupation, in the diligent pursuit of which he has been eminently successful, and has earned a name and station among his countrymen.

In 1840, retiring in part from the more active business of his manufactory, $\mathrm{Mr}$. Pratt employed a portion of his capital in the establishment of a bank at Prattsville, under the free banking law of the State of New York. A capital of $\$ 100,000$, secured in six per cent. stocks of the United States, and of the State of New York, is thus employed, and has been found extremely useful in that mountainous region, its business averaging nearly $\$ 1,000,000$ annually. It is one of the few institutions, the bills of which are kept actually at par by redemption in New York city.

Col. Pratt's first step in public life may be said to have been his election on the democratic ticket, for the State of New York, as an elector of President and Vice-President of the United States, in November, 1836. He recorded his vote, with those of his brother State electors, for his neighbor and friend, Mr. Van Buren.

In November, 1836, he was elected one of the Representatives in Congress for the eighth Congressional district, in the State of New York. He succeeded in this election, by a majority of twentyseven hundred votes, the largest majority, we believe, that was ever given in that district. He received very nearly the unanimous vote of the town of Prattsville.

Of his services in Congress, says the Review, it is sufficient to say that, in that body, he earned 
the character of a Working Man; that he gained the respect of all parties in Washington; and in his case was demonstrated the advantages which arise from sending men of practical knowledge and business habits to Congress; and how much that is really important to the people, may be performed by one such man, who is more desirous to act than to speak, and who cares less for the reputation of perfecting a useful measure, than the solid satisfaction of feeling that he has been instrumental in its accomplishment.

In July, 1738, Col. Pratt published an address to his constituents, declining a reëlection to Congress. In 1842, he yielded to their request, and was chosen to represent the eleventh Congressional district, composed of the counties of Greene and Columbia. On resuming his seat in Congress, his inquiry was not, "How can I make the most noise, or gain the greatest eclat?"--but, "How can I do the most work?" He never undertook to "define his position," or to make a speech for Buncombe. He made, indeed, few speeches, and they were commonly brief and plain statements of facts, which he knew could be relied upon. The value in any public body of men, who are patient and laborious in their search after truth, is beyond all estimate. In the words of one of our ablest political journals, it may truly be said, that "Colonel Pratt devoted himself to the utility of legislation. He has given his attention to political objects designed to advance science, the arts, commercial intercourse, the dissemination of useful knowledge, and to facilitate the practicable labors of the departments. Few men have accomplished as much in these important respects as he has done in the course of four years congressional service; and he has laid the foundations of good that will mature gradually hereafter, as views and suggestions, truly enlightened, and worthy a truly republican people and 
government, shall be brought to the popular consideration and action of Congress."

Representing a portion of the great agricultural State of New York-from his youth taught to look xpon the farming interest as the paramount pursuit in this country, and coming from a district where a very large proportion of the inhabitants find their profession, their pleasures and their profits in the noble employment of cultivating the soil, it must be supposed that the practical and utilitarian mind of Col. Pratt would dedicate a due share of its attention to the interests of agriculture. He originated the proposition, which was finally adopted by Congress, providing for the introduction, through our consuls and national vessels, of foreign seeds and plants, and for their gratuitous distribution to all portions of the country, through the medium of the patent office. The beneficial effects of this measure have already begun to be appreciated.

In 1842, Col. Pratt delivered an address before the Mechanics' Institute at Catskill, replete with excellent sentiments; and in 18.45, at the great fair of the Greene County Agricultural Society, at Cairo, he delivered a sound, practical address, which was extensively copied by the press. Few productions of the kind ever received more general commendation, or a wider circulation.

The personal habits of Col. Pratt, his attachment to the pleasures of home, and to the enjoyment of the natural delights of the family fireside, may be learned from the following particulars of his domestic life.

His first wife was Miss Beda Dickerman, of Hampden, Ct., to whom he was united Oct. 18th, 1818. She was a lovely woman, of amiable temper and true piety; but, the winter proving too severe for her constitution, she died of consumption, on the 19th of April, 1819. 


\section{Oh! mighty death-in such}

We must not build our hopes-in form of clay

We treasure up too much;

For 'tis a fearful thing to love what thou may'st touch.

After four years of mourning, he solaced his grief by taking the hand of her sister, who had won his affection by the resemblance she bore, in her virtues and beauty, to the deceased. But again was his dwelling turned into mourning by the entrance of the insidious prime minister of death, consumption, and his second wife died, at Lexington, Greene county, on the 22d of April, 1826, in the 31st year of her age.

Col. Pratt was united to his third wife, Miss Abigail P. Watson, daughter of Wheeler Watson, Esq., on the 12th of October, 1827. He now looked forward to an old age, solaced by the wife of his youth; but a voice from the invisible world whispered "come away," and his companion entered the blessed land, where sorrow is unknown. Although bowed to the earth with this heavy trial, which he bore with Christian resignation, he felt grateful for the possession of children, upon whom he could rally and concentrate his affections-toward whom he had duties to perform-and for whom it was a pleasure to live, and to exercise the energies of his mind. They furnished motives for continued industry and perseverance; rendered life still a blessing, and the hopes of the father cast a ray of sunlight into the future. One of his promising children, however, followed her mother to the grave a few months afterwards. The survivors, a son and an amiable daughter, are still spared, and furnish every hope that the latter years of their parent may be crowned with the supreme joy of a father's heart, viz: the knowledge that his example, his care, and his anxieties, have not been wasted. May his fond wishes be fulfilled to the utmost. 
Col. Pratt entered into wedlock a fourth time, on the 16th of March, 1835, when he married Miss Mary E. Watson, a sister of his third wife.

Alluding to his married life, in a letter to a friend, he says: "It has rarely fallen to the lot of man to say that he has had three of the best women for his wives, and that he is now living with the fourth, equally good. It may be most truly said of my deceased wives, that they were Christian companions, with whom I lived in the greatest conjugal happiness; and of my present most amiable consort, that she is in every way worthy to succeed them in the affections of a devoted husband, and every way calculated to promote his happiness."

From his youth to the present time, Col. Pratt has adhered to the good old rule, "early to bed and early to rise," always retiring by nine o'clock, and rising with the sun. The writer once heard him remark, that he never lost a single night's sleep in the course of his life. How many dreaming aspirants for wealth and honor are there, who can only speak of sunrise as an historical fact, never attested by their own observation!

The following incidents, selected from many others equally interesting, will serve to exhibit the character of the subject of our notice:

When the destructive fire occurred at Hudson, in 1844, reducing many families to great destitution and suffering, Col. Pratt immediately sent $\$ 200$ for their relief. It was the first money received, and afforded another illustration of the maxim, that "he who gives soon, gives twice."

In 1845, the Bible Society of Greene County fur nished a Bible to every family which did not pos sess one. The expense of this distribution, in his own town, was defrayed by Col. Pratt, who also gave a large and handsome copy for the pulpit of each church.

In the fall of 1845 , as he was passing up the road 
from Prattsville to visit a neighbor, he was accosted by a lad who said he had traveled on foot from New York city, having gone there to assist a drover with a flock of sheep-that on reaching the city, his employer having made an unfortunate speculation, cruelly turned him adrift without a cent, to find his way home at Oneonta. The poor fellow said "he felt rather bad about it; but, upon the whole, as he had got along so far, he thought it was of no use to despond." Col. Pratt, desirous of encouraging the boy's resolution never to yield to despondency at any ill luck or injustice, gave him a check on his bank, for a sum of money. Having with him neither pen nor ink, the Colonel picked up a flat stone and scratched the check upon its surface. This being presented, was paid at the counter of the bank.

He has often remarked, that although sometimes imposed upon by his acquaintances, he could generally determine the trust-worthiness of a stranger at first sight.

In 1843 , soon after the establishment of his bank, a drover came along with about two hundred cattle. He entered the bank and asked for Col. Pratt. "There he is," replied the cashier. The drover then stated that he was short of money, and desired, although a stranger, to borrow $\$ 100$, until he could drive his cattle to Westchester county, when he would remit the amount.

"Let him have it, cashier," said Col. Pratt, "the man has a good countenance."

"But," said the stranger, "you do not know my name"

"We shall soon see that, when you sign the receipt," was the reply, as Col. P. walked out to at-. tend to other business.

The honorable drover was Mr. Oscar Brown, of Westchester, who faithfully kept his word.

It was always the custom of Col. Pratt to say to 
his workmen, "come on," instead of "go on;" invariably taking upon himself those parts of the labor which were most disagreeable, and which required the greatest exposure. He has thus frequently stood in water all day, even in very severe weather. His temperate habits and hardy frame preserved his health unimpaired, amidst hardships which could have been borne but by few. At one time, during the building of a dam, a new hand, who had not yet entered into the spirit of the establishment, exhibited so much indolence as to attract the Colonel's especial attention. After dinner the latter took a coffee pot, and with a most commiserative look, said:

"Here, my friend; perhaps you would like to take this coffee pot and catch grasshoppers, to feed my fish in the artificial pond yonder, rather than to work with the rest?"'

"Certainly, sir," said the drone, as he took the coffee pot, and, with the agility of a grasshopper, threw himself over the fence into an adjoining meadow, no doubt wondering why he had so soon become a favorite.

Grasshopper No. 1 was soon caught and deposited in the coffee pot, "for safe keeping, and other purposes." Grasshopper No. 2 soon followed; but, as No. 2 went in, No. 1 jumped out; thus mimicking office holders under different administrations. But, nothing daunted, our hero performed wonderful feats of agility in seizing his prey, exhibiting the most surprising presence of mind in shutting down the lid of the pot just at the critical moment, catching his prisoners "on the hip." He was not, however alwars successful; and, after several consecutive vexatious mishaps, he sat down to repose on the laurels previously won. But, observing a very peculiar expression upon the faces of the workmen, a new idea entered his brain, and he quickly comprehended the joke. In a great rage, he immediately 
arose, dashed the coffee pot to the ground, strode away with disdain, and made tracks to parts unknown. To "work or catch grasshoppers," has now become a proverb in the tannery.

While in Congress, Col. Pratt having made some motion relative to the removal of the unsightly building in which the statue of Washington was immured, Mr. C. J. Ingersoll, in a vein of pleasantry, observed, "that the honorable chairman of the committee on public buildings would do well first to enclose the statue of the Indian lady, adjoining that of Columbus, the extreme scantiness of whose drapery had been severely commented upon by the press.

Col. Pratt instantly replied, that so delicate a duty could with peculiar fitness be assigned to the gentleman himself, who, if rumor spoke correctly, was a great adept at "enclosing" the fair sex.

At this happy retort, the house was convulsed with laughter, it being well known that the head of the committee on foreign affairs held it as a sacred duty to his country, and to himsclf, never to run away from the ladies, but on the contrary, when opportunity offered,

\section{To draw}

In one long kiss, their whole soul through Their lips, as sunlight drinketh dew.

On the face of the high rocks at the entrance of Prattsville, the eye of the stranger is attracted by several carved figures. Their origin is as follows:

A stone cutter, seeking employment, called upon Col. Pratt, and proposed to cut upon the rock, a bust of the Colonel, together with views of the tannery, etc. Struck with the novelty of the idea, and being ever ready to encourage men willing to labor, the proposition was assented to, and how well the artist has succeeded is evident to every beholder. Some, ignorant of the peculiar circumstances of the 
case, have attributed vanity as the motive; but Col. Pratt had a more elevated object in view. He looked forward to the time when, from the rapid consumption of timber, the whole region will be left without a tree, and when the traveler, a century hence, will gaze with wonder upon an inscription that, in the middle of the nineteenth century, a million of hides of sole leather were tanned from bark gathered on the spot, by Zadock Pratt, in twenty years.

Col. Pratt's services in Congress were eminently practical. He was one of the earliest advocates of the cheap postage reform, moving a resolution to that effect in 1838; and the information and statistics which he brought to bear upon the question, contributed in no small degree to the ultimate success of the measure. He submitted a valuable report on the improvement of the public grounds at Washington, together with a beautiful design, by himself, for a national monument to Washington. He also advocated, with hearty zeal, the remission of the fine, paid by the late President Jackson. In both congresses of which he was a member, he was an earnest advocate of, and introduced the bill for the establishment of a branch mint in New York.

The funds arising from the fees for patents, having accumulated to nearly $\$ 150,000$, Col. Pratt introduced a resolution to provide for the publication and engraving of all the important inventions patented at Washington, for the purpose of having copies of those works distributed to every town throughout the country, for the information of the people. Another resolution of great practical importance, introduced by Col. Pratt, and adopted by Congress, was that which requires an inventory of the public property in the hands of the public agents, to be made out once in two years, and reported to Congress. 
But the great measure to which he directed his attention, and urged upon that of Congress, was the establishment of a bureau of statistics. In January, 1844, he moved the preparatory inquiry, through a select committee, and on the 8th of March, he presented a luminous report in favor of the establishment of the bureau, with a bill prescribing its organization and duties. The report was accompanied by several elaborate statistical tables, illustrating the plan of the proposed bureau, and the mode of rendering efficient and serviceable its operations. The public press throughout the Union was unanimous in favor of the plan, but the only step which Col. Pratt could induce Congress to take, was the transfer of three clerks for this service in connection with one of the bureaux of the treasury department. It is to be hoped, however, that his plan will be filled up in every particular, as its adoption would be the means of saving millions to the country.

In 1839, he presented a report upon the quality of the different materials used in the construction of the public buildings at Washington-urging the policy and eventual economy of substituting marble or granite for the fragile and porous sandstone hitherto used. He demonstrated the propriety of the change with such force as to break down the opposition to the white marble, of which he proposed that the new General Post Office building should be constructed. "It is to the untiring perseverance of this gentleman," said the Washington Globe, "that we are mainly indebted for this beautiful specimen of the mechanic arts." And it may truly be said that this beautiful edifice, unsurpassed by any thing of the kind in the world, is his monument.

He presented the memorial of Asa Whitney, for aid in the construction of a national rail road, connecting the Atlantic and Pacific. Col. Pratt be- 
lieved the plan, though a stupendous one, was feasible, and that, once completed and properly managed, the road would become the great highway of nations. (In a recent address to the people of the United States, on this subject, he has presented an array of facts in favor of the project, which cannot easily be controverted.)

In February, 1845, he made a report on the extension of American commerce to Japan and Corea. This interesting document was extensively copied by the press. He proposed that measures should be taken to effect commercial arrangements similar to those with China, with the empire of Japan, containing a population of $50,000,000$, and the kingdom of Corea, having nearly 20,000,000 of inhabitants-believing that it would result in great and permanent advantages to this country.

He introduced the bill, which has since become a law, providing for the appropriation of the Smithsonian fund for improvement in agriculture, mechanics and literature, so as to benefit the people of all the states. He was also one of the most efficient advocates of the bill providing for a dry dock at Brooklyn, New York.

Many other important propositions were submitted by him, from time to time, which we have not space to enumerate. To do so, and justice to him, would require a volume. Some idea, however, of his indefatigable industry, while in Congress, may be formed from the fact, that the reports he made to the 2sth Congress, cover more than a THousand PAGES.

As an illustration of the perseverance of Colonel Pratt, when he has any useful object in view, it may be mentioned, that when he urged his proposition for building anew the war and nary departments, a southern member of distinguished ability and influence, who was opposed to the kill, objected, because, he said, the committee had not sub- 
mitted with their report the necessary plans and estimaies. Col. Pratt reminded the gentleman, that his objection must fall to the ground, as the plan and estimates were before the House; and taking them from the clerk's desk, he exhibited them to the objecting member; and the House, laughing at his objections, immediately passed the bill.

Before the inauguration of Mr. Polk, Col. Pratt urged the House for an appropriation to provide new furniture for the President's mansion. The old curtains and furniture were worn and shabby. The House seemed reluctant to respond, when Col. Pratt took the responsibility of ordering a new suit of curtains to be furnished, telling the upholsterer that if Congress did not pay the bill he would. The thing was done. A few days after, a southern member complained of Col. Pratt, that he had acted without authority. The Colonel promptly replied that he had ordered the curtains on his own authority, and if objections were made from any quarter, he should pay for them from his own funds. And he would respectfully ask the objecting member if he had ever done as much for his country as that? The laugh was turned upon the member, and the appropriation asked for was passed.

At the close of the twenty-eighth Congress, Col. Pratt declined a reëlection, in a very able address to his constituents, rendering a faithful account of his stewardship, and he is now engaged in the business of a banker, at Prattsville. He is still in the prime of life, enjoying unbroken health, and full of mental and bodily vigor, and has every prospect of living to achieve much good, as he possesses both the power and the will so to do. It may be said of him, that the great object of his life has been practical usefulness. He desired to leave the world something better than he found it. He has been eminently successful in all his enterprises-has preserved a character spotless for integrity and honor- 
and in the relations of a neighbor and friend, has no superior. As a citizen, he has done much for the public good; and, as a sound, practical, unswerving advocate of the interests of the working classes, has never been found wanting.

Adopting the language of the Review, we will add, that in selecting the founder of Prattsville as the subject of this memoir, we have been actuated by a desire to do merited honor to that noble and enterprising spirit, which marks the characteristic of the man, and to spread before the rising generation of our great and happy country, the benefits of his example. He stands out in bold relief, first making his fortune in active business, and then aiding in the councils of his country; and of him it was said, none more useful. History is said to be philosophy teaching by example, and history, after all, is but the record of the deeds of men. The life of the hero, who has led conquering armies, may be written, and while every one may honor his bravery, not one in a million can hope to benefit from his example. The lives of statesmen, of poets and philosophers, what are they, unless they show something practical to the world, something true and tangible, adapted to the feelings and pursuits of the masses? The life of one practical man like Franklin, Whitney, Slater, or Fulton, is worth more than all the Greek and Roman heroes that ever existed. These men became world-renowned, because they possessed, in an eminent degree, true energy, which, after all, is one of the chief elements of greatness. Their characters were self-formed-they rose from the masses, and as you follow them step by step, you see how they rose gradually to distinction; how the benefits they at last conferred on mankind grew up to perfection in the school of early trial, self-reliance, and neverfailing energy. We have the best of authority for saying, that "Faith without Works is dead." If 
this be true in spiritual things, it is equally true in temporal. The world is full of visionaries, and accounts of visionary men; but how little is written of the useful, practical, energetic, common-sense man.

We regard the career of Zadock Pratt as in many respects a remarkable one, and therefore we have chosen him for the subject of this memoir. If it be asked, what has he done? we might almost be disposed to answer by asking, what has he not done that the young men of the country should emulate? If we look back to his youth, we see him toiling to aid his parents, then the faithful apprentice to a saddler, always diligent, trusty and true. We see him as he approached manhood, exhibiting the energy and perseverance which have marked his character through life. As the business man, we see with what sterling integrity, admirable judgment and sagacity, alvays successful, from little to much, his affairs were conducted; how he breasted himself to every emergency, relying upon his own resolute heart and never idle hand, and the blessing of Grod, who has promised to help those who help themselves. We have seen him toiling for a competence, that he might do good, aiding others as he went along. We have seen with what courage he could endure the severest labors and exposures, even sleeping upon the snow, in pursuit of objects which he deemed essential to his prosperity and future usefulness. Conceiving the plan of establishing a great tannery, we see him plunging into the deep forests on the Catskill, and choosing with admirable judgment, a location for his works which is unrivalled, and can never again be equalled. This great establishment, under his auspices and persevering energy, we have seen grow up to be the largest of the kind in the world. Not only so, but we have seen this humble, pains-taking, laboring mechanic, almost with a magician's wand, 
erect a beautiful and prosperous town, in every public building and religious institution of which are seen the marks of his liberality. We have seen him building his hundred houses-the poor boy, whose first money was earned in picking huckleberries upon the Catskill mountains. When he came to settle in the little valley where the village now stands, he told the few inhabitants that he came to live among them, not upon them. He has kept good his word. He has accumulated a large fortune, never by impeding, but rather aiding the course of others-never pulling down any man, and without ever making a single enemy of any honorable man.

It has been said, that one of the best governors who ever ruled in Massachusetts, was an uneducated man. He was practical and sound in his views; knew the rights of the people, and respected them; knew their wants, and as far as possible provided for them. To him belongs the glory of first introducing free schools into that colony.

Colonel Pratt, though enjoying no advantages of early education, is not insensible to its importance, and has always been the fast friend and liberal patron of schools and institutions of learning, morality and religion. As a military man, we have seen him ever the friend of the soldier, and standing up nobly for the soldier's rights, and always the favorite of his company or regiment. We have seen him as the magistrate and supervisor, respected and honored, as the choice of the people for elector of President and Vice-President, and twice elected, with uncommon unanimity, to the Congress of the United States. In that great body, we have seen him nobly sustain his character of the wORKING MAN, earning the respect of all parties, and having the most entire confidence of his own. In short, we have seen him fill with distinguished ability the three positions of Farmer, Banker, and L gislator 
Well, then, may it be said of him, that no man did more for the good of the people; and when the judgment of the country shall be pronounced on his labors, it will be shown that no man originated so many great and important measures, whether we regard them in the light of economy, or of their ultimate effect upon the interests of legislation and of the people. We have seen that he labored in this great field, as he has always done, for the true interests of the farmer and mechanic, and for the working classes generally-proving himself equal to his business, and never above it, here or elsewhere. As the light and vivifying rays of the sun bring forth the early blossoms and rich fruits of the earth, scattering plenty and blessings around-so may it truly be said, that the HONEST MAN, who determines to be useful, and perseveres against whatever obstacle, giving employment to, and aiding the efforts of those around him, is the almoner of God's bounty to his fellow men. And it is no deterioration of the merits of the hero, the statesman, or the politician, to say, that the straight-forward USEFUL MAN, upright, energetic, and liberal, is the noblest of them all"an honest man's the noblest work of God." Such a man is Zadock Pratt; and his examples of industry and fidelity, perseverance and public spirit, as well as generosity, we would recommend to the observation of the youth of our land. Of him it may be truly said, when we review his plain, unostentatious and honorable career-marked by liberality in thought and deed-that he is one of "Nature's Noblemen"- an architect of his own fortunesand truly a Man of the People. 


\section{A BRIEF CHRONOLOGY}

OF THE

\section{LIFE OF HON. ZADOCK PRATT, A. M.}

1790, Oct. 30. Born at Stephentown, Rensselaer county, New York, and in his early days worked with his father at tanning, at Middleburgh, Scoharie county, N. Y.

1799. Was at the funeral of Gen. Washington.

1802. Removed to Windham, now Lexington, Greene county, N. Y.

1810. Apprenticed to Luther Hays, a saddler, in Durham.

1811. Worked at his trade a year as a journeyman saddler, at $\$ 10$ a month.

1812. Commenced business on his own account in Lexington, as a saddler, working from fourteen to sixteen hours a day. Here he commenced keeping an inventory, which he ever practiced afterwards during life, making over $\$ 500$ the first year, and never less a single year afterwards.

1814. Adds merchandizing to his saddling, and, by diligence and the strictest economy, is successful.

1814. Went as a soldier for the defence of New York city, then menaced by the fleets of the enemy; while there, he resists the corruption of the commissary, and forces him to do justice to the soldiers.

1815. Sells out his stock in trade, and is fortunate in escaping loss from the commercial revulsion which followed the peace ; forms a partnership with his two brothers in tanning.

1818, Oct. 18. Is married to Miss Beda Dickerman, of Hampden, Conn., who died 19th April, 1819.

1818, Dec. Makes a voyage by sea to Charleston, S. C. ; sea-sick going, and sea-sick coming; learnt enough of seafaring life.

1821, April 21. Unanimously chosen captain in the fifth regiment of New York State Artillery, and uniforms the company at his own expense. 
1821. In the winter of this vear makes an excursion to Canada, with leather, for the purchase of furs, during which he encamps in the woods upon the snow. Returning, is taken by a landlord at Albany to be a wanderer, not entitled to hospitality, on account of his worn and soiled garments, but who, on finding him possessed of a heavy bag of dollars, suddenly becomes the pink of politeness to our traveller.

1822, July 12. Is unanimously elected Colonel of the 116th regiment of infantry of the State of New York.

1823. Is married to his second wife, Miss Esther Dickerman, sister to his first wife ; she died 22d April, 1826.

1824. Is appointed Justice of the Peace for the county of Greene.

1824, Oct. 6. Received a vote of thanks from the Presbytery at Lexington, for a donation of $\$ 100$ in aid of the missionary cause.

1825. Built his great tannery in the woods of Windham, where has since grown up under his auspices the flourishing village of Prattsville, now numbering 2000 inhabitants, as industrious, prosperous and happy as any in the State-having now three churches, to the expense of each he contributed onethird, and one-half to the Academy.

1825. Escorts Gen. Lafayette into Catskill.

1826, Sept. 4. Resigns his commission as Colonel of Militia to the Governor of the State.

1827, Oct. 12. Is married to his third wife, Miss Abigail P. Watson, daughter of Wheeler Watson, Esq., of Rensselaer. She died Feb. 5, 1834.

1827. Is elected Supervisor of the town of Windham.

1825-1835. This was the busy scene of life-from 35 to 45 years of age-during which he accumulated a large portion of his wealth.

1832. The town of Windham divided, and the westerly portion called Prattsville, after the name of the founder.

1835, March 16. Married his fourth wife, Miss Mary E. Watson, sister of his third consort.

1835. Receives the thanks of the Delaware Circuit for the donation of a lot of ground for the use of the Elder of that Circuit.

1836, March. Builds a bridge over Scoharie kill, 130 fect long, the snow three feet deep in the woods, in eleven days; without the use of ardent spirits.

1836, Nov. Is elected a Representative in Congress from 
the Eighth Congressional District of New York. At the same election was chosen one of the Electors of President and Vice President from New York, and gave his vote for Van Buren and Johnson.

1837, Sept. 4. Takes his seat in Congress at the extra session, called by Mr. Van Buren.

1837, Sept. 4. Is appointed one of the standing committee on the militia.

1837, Oct. Receives the silver medal of the New York Ins:itute, being the first ever granted to a tanner, for the best specimen of hemlock-tanned sole leather.

1837, Dec. 11. Is appointed one of the standing committee on public buildings and grounds.

1838, March 11. Moved a resolution in favor of the reduction of postage, thus originating a great and favorite measure, which he rejoiced to see accomplished, and which has proved of such vast benefit to the whole United States.

1838, Märch 12. Presented the resolution of the State of New York, and submitted a resolution providing for procuring foreign seeds and plants, to be distributed gratuitously to the farmers of the United States, through the medium of the Patent Office, to benefit the farming interests.

1838, July 4th. Publishes an address to his constituents, partially reviewing the proceedings in Congress, and declining a re-election.

1839, Jan. 28. Moved a resolution of inquiry respecting the material of which the public buildings at Washington are constructed.

1839, Feb. 25. Presented a report on the quality of the materials used in constructing the public buildings at Washington, concluding with a resolution that the material hereafter used for that purpose, shall be of the hardest and most durable kind, either marble or granite. At the same time he submitted a plan and estimates for the new General Post-Office, and that building, the finest in Washington, has since been erected of marble, according to his plan, and is said to be the finest building in the world.

1839, March 1. Delivers a speech in the House of Representatives, on the subject of constructing a Dry Dock at Brooklyn, full of valuable statistics, on commerce, navigation, imports, exports and bullion, for ten years.

1839. Moved the bill for establishing a Branch Mint in the city of New York. 
1839, July 4. Delivers an oration at Prattsville.

1839, Sept. Was elected a member of the American Institute.

1839, Oct. 25. Offers five thousand dollars to endow an Academy in Prattsville, on condition that the like sum be raised by any Christian denomination.

1842, Nov. Is chosen a Representative in Congress from the Eleventh Congressional District of New York.

1842, Dec. 29. Delivers an address before the Mechanics' Scciety at Catskill, of which he was a member.

1843. Establishes a Bank at Prattsville, with $\$ 100,000$ capital, wholly secured by 6 and 7 per cent. stocks of the United States and State of New York-its bills kept at par in the city of New York.

1844, Jan. 3. Offers resolution providing for uniform annual returns of banks, suitable forms to be furnished by the Secretary of the Treasury, in order that a more perfect system might be adopted for the benefit of the community. He offered a similar resolution 11 th Jan., 1839.

1844, Jan. 8. Moved an amendment to the resolution in favor of the remission of the fine upon Gen. Jackson, to place on record the fact, that fifteen out of seventeen millions of the inhabitants of the United States had so instructed their delegations in Congress.

1844, Jan. 12. Gives notice of offering a bill for establishing a Branch Mint at New York; same day, gave notice for bill amending naturalization laws, which were afterwards presented.

1844, Jan. 17. Presented the resolutions of the Legislature of the State of New York to remit the fine of Gen. Jackson.

1844, Jan. 29. Moved the appointment of a select committee to inquire into the expediersy of establishing a Bureau of Statistics and Commerce, in connection with the Secretary of the Treasury. Is appointed chairman of said committee.

1844, Jan. Elected President of the Greene County Agricultural Society.

1844, Feb. Was on board the Princeton at the time of the explosion of its great gun, when Messrs. Upshur, Gilmer, and others were killed-and was the first man who had nerve, and was collected enough to attend at once to the care of the unfortunate killed and wounded.

1844, March 7. Makes a report on the application of the citizens of Washington to have a clock furnished at the public expense. 
1844, March 7. Makes a report on the situation, cost, \&c., of the public buildings and grounds, and expenditures of the Presidential Mansion.

1844, March 8. Submits a report as chairman of the select committee on the Bureau of Statistics and Commerce, with valuable tables, showing the loans and discounts of the banks, imports and exports, and balance of trade, for a series of years, of our government with other nations, illustrating the importance of the proposed measure, and concluding with a bill to wrovide for the collection of national statistics.

1844, March 18. Moved resolution respecting care and management of the furnaces used to heat the halls and rooms of the Capitol.

1844, April 12. Offers a joint resolution for the appropriation of the public ground for a National Monument.

1844, April 12. Reported bill for an addition of a wing to the Patent Office.

1844, April 12. Makes additional report on the plan submitted by him for fire-proof buildings for the War and Navy Departments.

1844, May 15. Moved joint resolution authorizing the transfer of certain clerks in the treasury department to perform the duties of the bureau of statistics, agreeably to the report of the select committee on that subject, which resolution was adopted.

1844, May 24. Makes report, with plan and estimates, on the proposed change of the Hall and Library of the House of Representatives.

1844, May 25. Makes report on the expenditures in the District of Columbia, from the foundation of the government, showing an expenditure exceeding ten millions of dollars.

1844, May 25. Makes report on the Monument Square, submitting a plan, diagram, and drawing for a National Monument to Washington.

1844, May 25. Moved joint resolution requiring an inventory once in two years, of all public property to be returned from all persons having any in charge, in order that public officers and legislators might have a more perfect knowledge of the property in charge of the govermment.

1844, May 25. Made report, accompanied with a joint resolution providing for the laying out and fencing the Monument Square.

1844, June 5. Offers joint resolution providing for the mode 
of making returns of public property in possession of officers of the government.

1844, June 7. Moved a joint resolution for the preparing and distribution of the national medals to the state libraries, colleges and academies.

1844, June 7. Moved resolution providing that monuments hereafter erected to deceased members of Congress, should be constructed of marble instead of sandstone, heretofore used.

1844, June 7. Moved a resolution directing topographical bureau to cause a plan of the city of Washington, and views of the capitol and public buildings to be engraved, and copies to be sent as presents by ministers and consuls, to foreign courts, translated into their languages.

1844, June 15. Resolution adopted on his motion, providing for the collection of statistics, on the plan of the bureau submitted in his report of the 8 th of March.

1844, June 17. Makes report on the errors in the sixth census.

1844, August 29. The democratic convention in Greene county passed a vote of thanks to Col. Pratt for his eminent public services, and untiring devotion to the business of the present session of Congress, and especially in placing on record the fact that more than 14,000,000 of American freemen had instructed their representatives to vote for refunding to Gen. Jackson the fine imposed upon him while fighting for his country at New Orleans. In establishing a Bureau of Statistics, which is of incalculable benefit to Legislation-to government in all its departments, and to the business men of the country. In causing a resolution to be passed, by which the inventions of our mechanics which are patented are to be lithographed and furnished to each town free of expense. For his admirable taste in the construction of public buildings, in the laying out and disposition of the public grounds, and in the surpassingly beautiful monument to the memory of Washington. In the various and able reports from time to time submitted by him to that body, and finally in causing government like individuals to take and keep an inventory of the property of the nation.

1844, December 4. Moved a resolution authorizing the sec retary of war.to loan marquees and tents to state agricultural societies for their fairs.

1844, December 26. Introduced joint resolution providing for periodical renewals and greater security of bonds of public officers. 
1844, December 31. Moved joint resolution providing for the selection of a site for the National Washington Monument.

1844, Dec. 31. Makes report on the necessity of providing additional buildings for the accommodation of the War and Navy Departments.

1845, January 10. Reports bill providing for the painting, repairing, \&c., of the Presidential Mansion, and other public buildings.

1845, Jan. 11. Received vote of thanks from the Washington Monument Society, for his untiring exertions in their behalf, and for the plan and map by him submitted.

1845, January 28. Offers joint resolution for the preservation of flags, and other trophies taken in battle.

1845, January 28. Makes report on national trophies, accompanied with the above resolution.

1845, January 28. Makes report with plans and drawings, and estimates for the War and Navy Department, accompanied with bill.

1845, January 28. With introductory remarks, presents the memorial of Asa Whitney, on the importance of a National Railroad to the Pacific.

1845, January 28. Submits reports on the ventilation of the Representatives' Hall, and to prevent the echo so much complained of by speakers.

1845, February 7. Submits additional report on the importance of a statistical bureau, accompanied with a joint resolution for the establishment of the same.

1845, February 15. Submits proposition for the extension of American commerce, and proposing a mission to Corea and Japan, a people of over seventy millions, with whom we have no communication, and whose ports our ships are not allowed to enter.

1845, February 19. Presents a memorial from forty-seven editors and authors in favor of placing magazines and periodicals on the same footing with newspapers as respects mail privileges, in furtherance of his plan of providing for a cheap and uniform postage.

1845, February 21. Moved resolution for the appointment of three commissioners to investigate the public departments and bureaux at Washington, with a view to a better organization, and an equalization of duties and salaries of public officers.

1845. Moved estimates and plan for erecting dwellings for the five heads of departments, opposite the Presidential Mansion. 
1845, February 25. Makes report on the statistics of the United States, the population, revenue, production, and showing the relative condition of the northern and southern states.

1845, February 25. Makes a report on the national edifices at Washington.

1845, February. That three Commissioners be appointed whose duty it shall be, during the recess of Congress, to examine into all the departments in the various offices of government, with the view of remodelling said departments, for the purpose of equalizing salaries and duties.

1845, February 26. Reports a bill for amendment of the naturalization laws.

1845, February 27. Moved an amendment to the general appropriation bill, providing for the survey, under direction of the Secretary of War, of a rail road route from Lake Michigan to the South Pass of the Rocky Mountains, to Oregon.

1845, February 28. Moved a bill respecting the Smithsonian Institute, the substance of which has since become a law, providing that a portion of the income of the Smithsonian fund should be appropriated for the improvement of agriculture and the mechanic arts.

1845, March 3. Makes report on the salaries of all the officers employed at Washington, showing the amount received by each, and the states from which they were appointed.

1845, March 3. Makes report on the duties upon imports and tonnage and revenue, by states, showing the amount collected each year, from the foundation of the government.

1845, March 3. Makes report on a proposed new mode of taking the yeas and nays in the House, by machinery connected with the Speaker's table.

1845, March 5. In an address to his constituents, reviewing his acts while in Congress, and giving an account of his stewardship, he declines a re-election to Congress.

1845, June. Receives thanks of the Greene County Agricultural Society for a donation of $\$ 250$, for the promotion of agriculture and the mechanic arts.

1845, July 1. Is elected an honorary member of the Franklin Institute of the State of Pennsylvania, (in the city of Philadelphia,) for the promotion of the mechanic arts.

1845, September 25. Delivers an address before the Greene County Agricultural Society, of which he was President.

1845. Offers resolution providing for the engraving of 
patents, and their distribution to every town and county and public library in the United States, for the benefit of mechanics, to whom those inestimable plans are now like a sealed book.

1845. Offers a resolution providing for the execution of busts, by native artists, of all the Presidents, to be placed in the Capitol.

1845. Moves a bill providing for the establishment of the free banking system in the District of Columbia, similar to the free banking law of New York.

1845. Offers a resolution calling on the secretary of state to furnish the statistics of Texas, pending her admission into the Union.

1845. Is elected an honorary member of the Peithessophian Society of Rutgers College, New Jersey.

1846. Received a similar honor from Middletown College, Connecticut.

1846. Closed the concerns of his tannery at Prattsville, after tanning over a million sides of sole leather, using one hundred and fifty thousand cords of bark, from ten square miles of bark land, and clearing over five thousand acres, one thousand years of labor, and some $\$ 6,000,000$ of money, without a litigated law-suit, or having a single side stolen.

1846. Elected honorary member of the Louisiana State Agricultural and Mechanics' Association.

1846. Is elected a corresponding member of the American Agricultural Association.

1847, March. With a view of acquiring, from personal observation, a practical knowledge of the peculiar institutions of the south, as compared with those of the north, makes a tour with his son, then a lad of eighteen, through the whole of the southern and south-western states.

1847, August 28. Addresses a letter to the people of the United States, on the importance of a railroad across the continent to the Pacific ocean.

1847, September 23. Delivers an address at the dedication of the Spencertown Academy.

1847, November 22. Receives thanks from Spencertown Academy, for a liberal donation.

1847, November 27. Communication in answer to an inquiry of the American Institute, explaining the system of the Pratts- 
ville tannery, of its management, and the extent of its operations.

1848, January 4. Delivers a lecture before the Mercantile Library Association of the city of Hudson. Subject : Mind your business.

1848, January 4. At the annual meeting of the Greene County Agricultural Society, held at Cairo, it was-Resolved, That the thanks of the Greene Co. Agricultural Society be tendered to the Hon. Zadock Pratt, late President, for his valuable services and able superintendence of the affairs of the said society; and also-Resolved, That the thanks of the said society be presented to Hon. Zadock Pratt for his liberal donations in sustaining and carrying out the measures and objects of said society.

1848, January 14. Received the thanks of the Greene Co. Baptist Missionary Society, for donation.

1848. The American Biographical Sketch Book, containing the lives of 130 eminent citizens, with portraits, was dedicated by the Editor, Wm. Hunt, Esq., "To Zadock Pratt, the Friend of the Mechanic, and the Patron of all that is useful." This same year, "Scientific Agriculture, or the Elements of Chemistry, Botany, and Meteorology, applied to Practical Agriculture, by M. M. Rodgers, M. D.," was dedicated to Hon. Zadock Pratt.

1848. Makes the third annual report to the N. Y. State Agricultural society, as president of the Greene County Agricultural Society, giving the geological, agricultural and commercial statistics of the county of Greene.

1848, March 7. Is elected a corresponding member of the New York Historical Society.

1848, July 23. Received the honorary degree of Master of Arts from Union College; the first instance in this state of a similar honor conferred upon a self-taught mechanic.

1849, January 2. Elected President of the Mechanics Institute of the city of New York.

1849, January 16. Delivers an address on his inauguration as President of the Mechanics Institute, City Hall, N. York. 



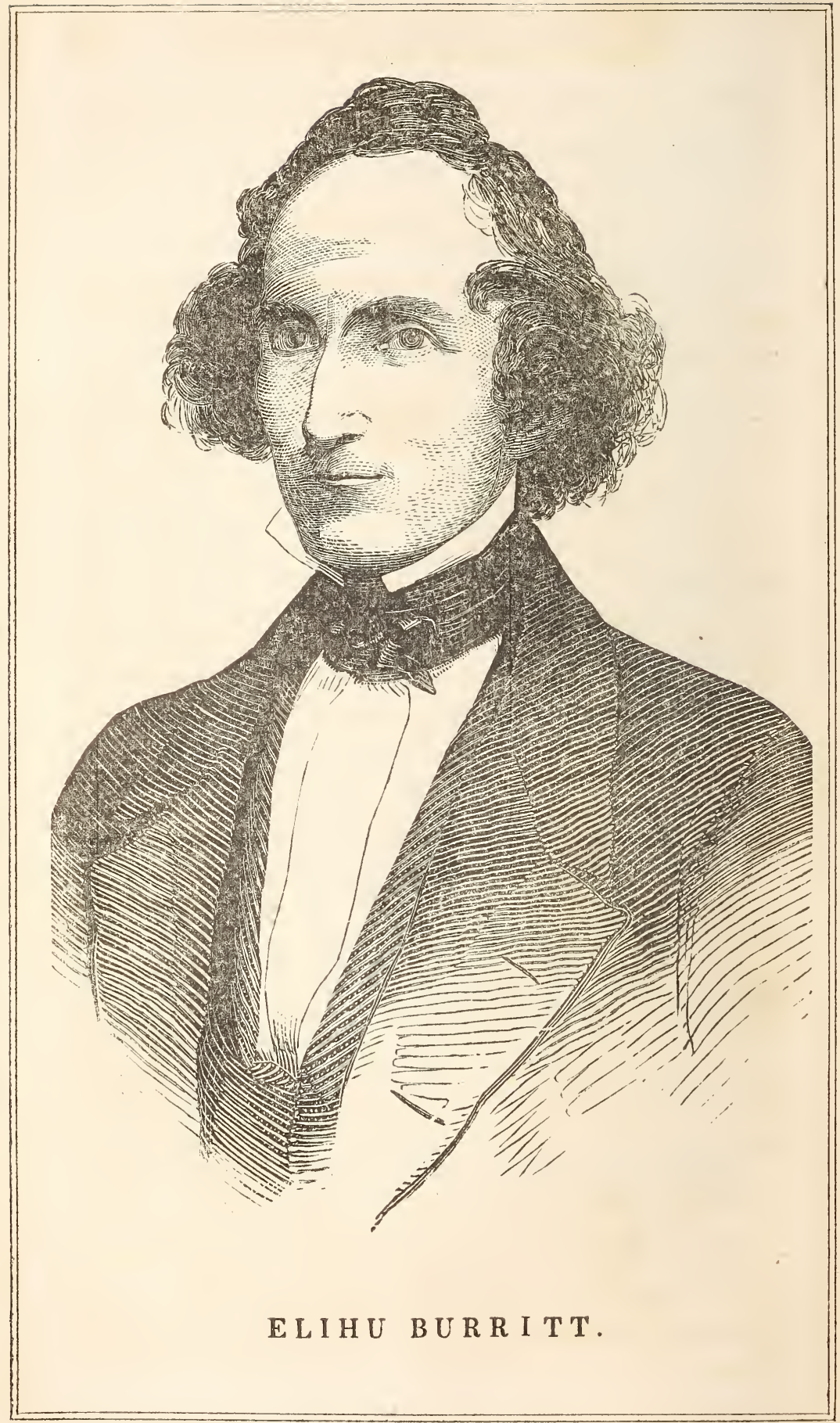




\section{EITHU BURRITT.}

Among the many remarkable men of this remark able age, no one seems to us more worthy of notice than the "Learned Blacksmith."

Elihu Burritt, says Mary Howitt, is not merely remarkable for his knowledge of languages - a knowledge which is perfectly stupendous, and which having been acquired under circumstances which, at first sight, would seem to present insuperable barriers to anything beyond the most ordinary acquirements, may naturally excite our surprise and admiration - but he is remarkable in a high moral degree; and this it is, combined with his great learning, which entitles him to our love and reverence. His many-languaged head is wedded to a large and benevolent heart, every throb of which is a sentiment of brotherhood to all mankind. Like an apostle of peace and good-will, he has come among us, with the clasped hands as his cognizance, as a teacher and promulgator of Christ's own doctrine of love. He has not read Homer and Virgil, and the Sagas of the North, and the Vedas of the East, to admire only, and to teach others to admire the strong-handed warrior, cutting his way to glory through prostrate and bleeding thousands: he has read only to learn more emphatically, that God made all men to be brethren; and that Christ gave, as the sum total of his doctrines, that they should love one another. This is the end of all his reading and learning; and better, by far, to have learned thus, with hard hands and a swarthy brow, over the labors of his forge and hammer, than to have studied in easy universities, to have worn lawn and ermine, yet have garnered no expansive benevolence while he became a prodigy of learning. 
His family are describcd as possessing his virtues. If any one in the town met with a misfortune, lost a limb, or became halt, or blind, or dumb, he became to this good family an uncle or an aunt. What a sermon might be preached from this text.

Being the youngest of the five sons, it was the privilege of Elihu to remain at home with his parents, and contribute to the support and comfort of their old age. Among the pleasantest reminiscences of his earlier life are the exertions he made for this purpose. At sixteen he had arrived at the full stature and strength of man. He now united himself with the congregational church in New Britain, under the pastoral charge of the Rev. Henry Jones; and is at the present time a member, in regular standing, of the same church, whose articles of faith are the same as those of the Independents in England. At this time his father's first and last illness commenced, which lasted for almost a year. During the whole of this time, this excellent son labored through the day in the field or forest, and then watched through half the night at the bedside of his father, that his mother might be enabled to take necessary rest.

After his father's death he apprenticed himself to a blacksmith of the town; the only school education he had as yet received, being three months at a district school during the winter, before he was fifteen. Of far greater importance, however, than this scanty tuition, was the keen appetite for reading which kept his mind awake; and which was doubtless stimulated by the difficulty he had in procuring books.

Soon after the age of sixteen, and while working at his trade, he took up his residence with his brother Elijah, who had opened a school. By Elijah's advice, however, when his term of apprenticeship had expired, and he was one and twenty, he 
laid aside his hammer, and became a student with his brother for one half-year.

After this half year of study, in the spring, he found himself well versed in mathematics; he had gone through Virgil in Latin, and had read several French works; he was, therefore, well satisfied with himself, and returned again to the forge, determined to make up for lost time. To accomplish this thoroughly, he engaged himself to do the work of two men, and thus received double wages. Severe as this labor was, and requiring fourteen hours of each day, he still found time to read a little of Virgil, and a few pages of French morning or evening. $\mathrm{He}$ at this time also first began to look into the Spanish, which, to his delight, he found he could read without much difficulty. During this summer he conceived the idea of making himself acquainted with Greek.

With autumn came self-dissatisfaction. He saw again the intellectual world lying before him, like an undiscovered land; and again he resolved to sacrifice a whole winter to extend that knowledge which was so necessary to him. He left his furnaces, therefore, and went to New Haven, ; not, as our readers may imagine, with the intention of entering Yale College, but with a vague sort of notion that the very atmosphere of that seat of learning would facilitate his progress. If, however, this did not much assist, it certainly did not retard him, for the intellectual labor of this winter seems perfectly miraculous. On arriving in the town he took lodgings at an inn, and commenced a course of study on the following plan, which we will give in his own words.

"As soon as the man who attended to the fires had made one in the common sitting-room, which was at about half-past four in the morning, I arose, and studied German till breakfast, which was served at half-past seven. When the boarders 
were gone to their places of business I sat down to Homer's Illiad, without a note or comment to assist me, and with a Greek and Latin lexicon. A few minutes before the people came in to their dinners, I put away all my Greek and Latin, and began reading Italian, which was less calculated to attract the notice of the noisy men who at that hour thronged the room. After dinner I took a short walk, and then again sat down to Homer's Illiad, with a determination to master it without a master. The proudest moment of my life was when I had first possessed myself of the full meaning of the first fifteen lines of that noble work. I took a triumphal walk in celebration of that exploit. In the evening I read in the Spanish language until bed-time. I followed this course for two or three months, at the end of which time I had read about the whole of the Illiad in Greek, and made considerable progress in French, Italian, German and Spanish."

When winter was over he returned to New Britain to his trade. The fame of his learning had preceded him, and he was induced to undertake the management of a grammar school in a neighboring town. Afier a year his health suffered from confinement, and he was induced to give up his school.

He then engaged himself as travelling agent to a manufacturing company in New Britain. This mode of life continued for twelve months, during which he made his first essay in original authorship, in a story called "My Brother's Grave." Thus a new faculty was discovered, and ever after, the pen became a medium of communication between him and the public.

His next change was to commence business on his own account in New Britain; but unfortunately, this was just before the great commercial revulsion, which was felt not only in America, but also in 
England; and Burritt, like many another trader, was an unsuccessful man.

His mind was now turned to the study of the oriental languages, but a difficulty soon arose from the want of books. To overcome this difficulty, he resolved to make a voyage to Europe, working his way across the Atlantic as a common sailor, or in any other capacity in which he could receive wages for the work of his hands. Boston was the nearest port, at the distance of a hundred and twenty miles, and to Boston he set out on foot. All his worldly wealth went with him; his change of linen tied in a handkerchief, three dollars and an old silver watch in his pocket, which watch was of no use to him, as it did not go, and he could not afford to have it mended. His mother furnished him with gingerbread, and other light provision for the journey.

Footsore and weary, after a travel of a hundred and twenty miles, he arrived at Boston to find that no vessel was sailing from that port. He learned, however, to his comfort, that an antiquarian library existed in the town of Worcester, which was forty miles distance; and to that place he now resolved on going, determined to take work as a journeyman, and to gain access to the library. A feeling, however, of unwonted depression lay heavily on his mind; he was exhausted by bodily fatigue, lame, and reduced in finance to one dollar and the old watch. He limped along the streets of this city as he was about to leave it, feeling himself poor and weak, and mean, in comparison with the very walls of the houses, which, as he glanced up to them, looked to him, as he himself has been heard to say, like the walls of the New Jerusalem. When he reached Boston bridge on his way to Worcester, he was overtaken by a wagon which a boy was driving. On inquiry, he found that the boy was going to Worcester, and was willing to take him there as he 
requested. This was a great god-send to his weary frame, for it was forty miles to that town.

Burritt very soon engaged himself as a journeyman blacksmith, at the low rate of twelve dollars a month, with board. A very short time sufficed to show him, that the antiquarian library of Worcester could be of little or no use to him; and this discovery filled him with deep sorrow. The library was open to the public but a certain number of hours in the day, and these were the very hours when his duty as a journeyman smith confined him to the anvil. He continued, therefore, his Hebrew studies unassisted, as he best was able. Every moment which he could steal out of the twenty-four hours, was devoted to study. This severe labor of mind, as might be expected, produced serious effects on his health; he suffered much from head aches, the characteristic remedy for which were two or three additional hours of hard forging, and a little less study. We will copy from his diary of this date, one week's work, as a specimen of the whole, and our readers may then judge of the gigantic labors of this Titan of learning.

"Mondxy, June 13.-Headache ; 40 pages Cuvier's Theory of the Earth; 64 pages of French; 11 hours forging.

"T'uesday.-65 lines Hebrew; 30 pages French; 10 pages Cuvier's Theory; 8 lines Syriac; 10 lines Danish; 10 lines Bohemian; 9) lines Polish; 15 names stars, 10 hours forging.

"Wednesday.—25 lines Hebrew; 50 pages of astronomy; 11 hours forging.

6. Thursday. - 55 lines Hebrew; 8 lines Syriac ; 11 hours forging.

"Friday.-Unwell; 12 hours forging.

"Saturday.-Unwell; 50 pages Natural Philosophy; 10 hours forging.

"Sunday.-Lesson for Bible class." 
So wore on the year of 1837 . The next year he engaged himself to work by the piece, and was thus able to arrange his time so as to make the library of use to him. Burritt had already studied the Celtic tongue, and with this an interesting circumstance is connected; he found in the library a grammar and dictionary of the Celto-Breton tongue, which had been presented by the Royal Antiquarian Society of Paris. Suddenly it occurred to him that it would be a fine thing to write a letter in that language to the president of that society. In three months the language was mastered, and the letter duly forwarded to Paris, in August, 1838.

About a year afterwards, a gentleman residing in Worcester, presented himself before him, as he was at work at the anvil, bearing in his hand a large packet addressed to him. This was from the Royal Antiquarian Society of Paris, containing a letter from the secretary, acknowledging, with honorable mention, his communication in the Celto-Breton tongue; and forwarding to him the Transactions of the Society, and many other interesting documents. Burritt declares this to be the most gratifying incident that ever occurred to him connected with his studies. About the time of this remarkable letter, he commenced his studies of the various languages of the Scandinavian and Sclavonic field.

He had begun to communicate, as we have already said, with the public through his pen, and he now conceived that he might add to his small earnings by translations from various tongues, particularly the German. He wrote, therefore, to a gentleman whom he thought could be helpful in this way, giving him a short history of his life and of his present views. This letter was sent to Governor Everett. Governor Everett read his letter at a public meeting. A great deal was said on the subject, and all at once he found himself, as he says, "laboring under notoriety." 
A few days afterwards, he received an invitation to go to Boston on a visit to his excellency. To this city, accordingly, he once more came. How different this time to the last; then poor and footsore, and oppressed by a sense of his own nothingness - now on a visit to Governor Everett, by his own express desire!

Nothing could exceed the kindness with which he was received; every offer was made him which could facilitate his studies; he was requested even to enter Harvard College; many were the persons who generously came forward to assist him, and offer him every advantage in the prosecution of his studies; but he preferred the old course; there was a pleasure to him in it; he loved to feel that he was still of the ranks of the working man. Hear this, working men of America, and honor him for it. He was happy, he was proud to labor with his hands as you do! He courteously declined the help proffered to him by the great and the wealthy, and stated that he thought he could make better progress by pursuing his own course.

He returned again to Worcester, applied to labor harder than ever, and commenced, in 1839, a monthly periodical called the Literary Gemini, in English and French, designed principally for the students of the latter language. This was not a successful speculation to him, and after a year it was discontinued. His fame, however, by this time, had spread far and wide; and during the winter of 1840, he received invitations to lecture in various cities, which he accepted. In 1s41, finding his journeyman's wages inadequate to his requirings, he began to trade a little on his own account. He hired an anvil, which he set up in one corner of the shop, and worked here at over-time, in the making of gardentools, which brought in a little extra money. All went to assist in his favorite studies, and his life was happy. 
As may naturally be supposed, the press was anxious to obtain his aid, or the advantage of his name. He wrote accordingly; more particularly for the American Eclectic Review, which was intended to contain the literature of the world. For this work he translated several of the Icelandic Sagas, as well as a series of papers from the Samaritan, Arakic, and Hebrew. During the winter of 1842 , he again lectured, among other places, at New Iork, Philadelphia, Baltimore, Albany, \&c., where the fame of his acquirements, as well as admiration of his character, drew together large audiences. In the course of this season he lectured no less than sixty-eight times. In the spring he returned to his trade in Worcester, where he commenced the study of the Ethiopic, Persian, and Turkish languages.

Thus passed his time for the next two years; in the winter lecturing - in the summer working and studying. After that time, in 1844, having saved a few hundred dollars, he commenced his paper, called The Christian Citizen; a paper portioned out in a systematic manner, and devoted to religion, peace, anti-slavery advocacy, education, and general information. With regard to the subject of peace, we must state that, shortly before this time, his mind had taken a decided bent. Naturally there was a tendency in him, as every one must beliere, to an admiration of the heroic. The vanquisher of difficulties, the victor in any sense, was to his feeling an object of respect and admiration.

On the 16th of June, 1845, Burritt left America for England. He went out in the Hibernia, the same ressel which carried the news of the settlement of the Oregon question. At the very moment when he stepped on board, he heard the joyful tidings announced that there should be no war.

For a year or two he had been agitating in his mind the scheme of a grand Peace League, which should be, to all questions of peace and free trade 
what the Anti-Corn-Law League had already been to that question. He wished that every one, of any land, who was willing to coöperate, should be members of it; that it should embrace all nations; that the very world should be its platform. The scheme is a grand one; and it seems to him, on coming to England, that a conjuncture of favorable circumstances at that moment was propitious to its commencement. The idea was never absent from his mind, but even more suddenly than he expected did he bring it into operation. He was on his way to London, alone and on foot, when he came to the small town of Pershore, nine miles from Worcester, on the evening of July 29th. It was his intention to stay here for a day or two to write. Here he drew up the pledge which he intended to be signed by the members of the future League of Peace; he bought a little note book, into which he entered it. The same evening, a Mr. Conn invited him to drink tea with him and his friends. Therc were about twenty in number; he spoke of the pledge, and read it to them, having first signed his own name to it; at once were added, as he himself has chronicled in this same little book, "the names of seventeen men of Pershore-gnod men and true." Thus commenced the league of universal brotherhood-may it gather the whole world in one fraternal embrace!

Burritt has traveled already through many parts of England, meeting everywhere with a cordial welcome. At the same time the League of Peace progresses rapidly in America; its numbers increase daily on both sides of the Atlantic, and thus shall two great countries be knit together.

Mr. Burritt was born at New Britain, Connecticrit. Dec. 8, 1811. He is in his 37th year. 


\section{MARTIN VAN BUREN.}

Although the history of this eminently self-made man is familiar to all, a synopsis of it cannot be omitted in a work of this character.

Martin Van Buren was born at Kinderhook, Columbia county, New York, on the 5th of December, 1782. He was the eldest son of Abraham Van Buren, a farmer of moderate means, and who was descended from one of those families "who at an early period in the history of this country, emigrated from Holland, and settled in the ancient town of Kinderhook." He was a man of strong common sense, and distinguished for his pacific disposition. His wife, whose maiden name was Hoes, is said to have been a woman of amiable disposition, exemplary piety, and more than ordinary sagacity.

Martin, their son, at a very early age, exhibited signs of a superior understanding, but owing to the moderate property of his father, his opportunities for early instruction were few. Even at that period he gave indications of what he afterwards became, as the following incident, related to the writer some years ago, by an aged relative of the family, will show.

"Martin and I," said our informant, "when quite young lads, were accustomed to play together in a barn near our dwelling. On one occasion he lay on his back upon the barn floor for a considerable time, as if in deep study. What ails you, Martin? said I; whereupon he sat up, and slapping his thigh, said: 'I'll tell you what-from this time I'm determined to be something or nothing.'"

It appears that he was remarkably fond of mischief, generally taking the lead in any boyish frolic. The writer has seen the tears roll down 
the cheeks of an old Dutchman named Younghans, as he would laughingly relate how "he used to chase that young Martin out of his orchard," and that how, "without shoes or stockings, the mischievous youngster would scamper over the fence like a squirrel."

At the age of fourteen, with but very slender acquisitions, he commenced the study of law in the office of Francis Sylvester Esq., a respectable lawyer of Kinderhook, where he soon gave indications of no ordinary ability as a speaker and a reasoner. The last year of his preparatory studies was passed in the city of New York, under the superintendence of Mr. William P. Van Ness, a distinguished member of the bar. In November, 1803, in his twenty-first year, Mr. Van Buren was admitted an attorney of the Supreme Court of the State of New York; after which he commenced the practice of his profession in his native village. Here he continued until his removal to Hudson, in 1808, in which place he remained until his final withdrawal from the bar, in 1828.

In the thirtieth year of his age he became a state senator. In 1815 he was appointed attorney-general. In the spring of 1816 he was reëlected to the state senate for a further period of four years. In 18:1 he took his seat in the United States senate. On the 1st of January, 1829, he became governor of the state of New York. In March, of the same year, he was appointed by President Jackson, secretary of state of the United States. In 1831, he went as minister to England; but in January, 1832, his nomination was rejected in the senate by the casting vote of the vice-president. On the 4 th of March, 1833, he was inaugurated as vice-president, and on the 4th of March, 1837, the boy who, when lying on the barn floor, declared that "from that time he would be something or nothing," became President of the United States! 
What an encouraging example does his success present to the young men of the country! Few are denied advantages of education fully equal to those which he possessed. But let them bear in mind that

Not without toil is Fame's bright palace won;

Or glory's race, with faltering footsteps won.

\section{JOHN VAN BUREN.}

This distinguished gentleman, the son of Martin Van Buren, ex-president of the United States, was born at Hudson, Columbia county, New York, on the 18th of February, 1810. He graduated with honor at Yale College, New Haven, in September, 1828. He studied law with the Hon. Benjamin F. Butler, first at Albany, and afterwards at Washington city. He concluded his legal studies with the Hon. Aaron Vanderpoel. $\mathrm{He}$ is represented as having devoted himself with untiring zeal to his profession, and like his father, frequently in the stillness of the night "burying his whole soul in the researches of science, and at that propitious season, kneeling at the shrine of that jealous mistress which knows no rival." In July, 1831, he was admitted to the bar. In August of the same year, as one of the legation, he accompanied his father to London; the latter going as Minister to England. During a few years absence, the subject of this notice embraced every opportunity of indulging his love of the sublime and beautifulrambling among the ancient ruins of baronical grandeur, and visiting the feudal castles, venerable abbeys, and old English churches: 
As beautiful they stand,

Those ancient aliars of our father land!

Amid the pasture fields and dark green woods,

Amid the mountains, clouds, and solitudes;

$\mathrm{By}$ rivers broad, that rush into the sea,

By little brooks, that with a lisping sound, Like playful children, run by copse and lea!

Each in its little spot of holy ground, How beautiful they stand,

Those old gray churches of our father land !

He also visited France, Switzerland, and Italy, traveling among the "fallen columns, crumbling walls, and ivied arches, and all the sad relics of the mighty race which once thronged upon the banks of the Tiber, and sported upon its golden waves."

On the rejection of his father by the Senate, in 1832, Mr. Van Buren returned with him to the United States.

On the 22d of June, 1841, Mr. Van Buren was united in marriage with Miss Elizabeth Vanderpoel, eldest daughter of the late James Vanderpoel, judge of the third circuit. But in this life shade and sunshine alternately follow. Shortly after their marriage, his lady's health began to decline, and in the fall of 1843, with a view of restoring it, they visited the island of Madeira. The air was balmy, and the spirit of man glowed as if a new effusion of the elements of health had issued from the gates of heaven; but the breeze, pure, delicious, and invigorating as it was, freshening to all the pulses of nature, came not to her with "healing power." After spending the winter there, they returned by the way of the West Indies, passing sometime in several of the West India Islands, particularly in Santa Croix, that isle of undying verdure, with its purple hills, and sky of purest azure. The destroyer however could not be eluded. He followed her over the deep blue ocean, over the lofty mountain, by the thundering cataract, and through forest, glade and glen; and shortly after her return, in November, 
1844, the fatal dart was sped, and Mrs. Van Buren left the perishing things of earth for that "better land."

Life is full of instruction. "If sorrow never visited man, he would spend his days in delicious dreams, until startled by the cold hand of death. The Creator seems to have designed that fallen humanity should be marked by vicissitude. The stream is broken by obstacles that make music, and keep its waters pure; the crushed flower yields sweetest fragrance, and the rock rent discloses its gems."

In May, 1838, Mr. Van Buren visited England on professional business. The coronation of Queen Victoria in that year, drew to London a great concourse of English people, and foreigners of distinction, and was the occasion of much festivity. As the son of the President of the United States he was invited very generally to the public and private parties; and the marked attention which he received from the nobility, and from the Queen herself, the particulars of which may be found in the papers of the day, were of a most flattering character. In October of that year, he started for America in the Liverpool, a new steamer on her first trip. The greatest confidence was placed in this vessel, as

With foam before, and wind behind

She rent the clinging sea,

That flew before the roaring wind,

Beneath her hissing lee.

And for some days she went like a winged thing through the waters. But a tremendous gale was soon encountered; and the ocean, rolling in all its vastness, appeared as if mocking the puny inventions of man. To proceed was impossible; and on the next day, having made but five hundred miles, and consumed half their fuel, they were compelled to put back and land in the Cove of Cork. 
The far advance of the season, and the unsatisfactory experiment of the steamer, together with a great desire to see Ireland, induced Mr. Van Buren to defer his return till the following spring. He spent the next two months in traveling over Ireland, visiting Killarny, Dublin, the Giant's Causeway, Dunluce Castle, and almost every other place of note. The merchants of Belfast tendered him the honor of a public dinner, and every body in Ireland treated him with the warm hearted hospitality peculiar to the "Gem of the Sea." From Coleraine in Ireland, he passed over to Glasgow, and spent a month or more in Scotland, visiting Fingal's Cave, the "banks and braes" of her bonnie rivers, sundry places "famed in storie," and remaining a week or ten days in Edinburgh. Returning to London, he went fiom thence to Paris, where he passed a month with our then minister, General Cass; thence through France, Belgium and Holland, and back to London, from whence he returned to New York, by the Great Western, in May, 1839 , having passed a very agreeable twelve-month, and accomplished the business which carried him out. While in Europe, he had the good fortune to form the acquaintance, and enjoy the society, of most of the eminent men of the countries through which he passed.

On the first Monday of February, 1845, Mr. Van Buren was appointed attorney-general of the state of New York, for the term of three years. In this capacity he has been engaged in several important and laborious trials, such as that of Dr. Boughton, at Hudson, O'Conner and others, at Delhi, and when he had opposed to him some of the ablest counsel which could be procured. On those occasions the public press of both parties, gave him credit not only for his ability, but for his liberality towards the accused. In December, 1845, Mr. Van Buren argued a very important case in the supreme court, 
at Washington, having for his opponents Messrs. Webster and Ogden. In this instance, he by no means lessened his reputation as a sound lawyer. $\mathrm{He}$ is not one of those who, from vanity, injure the cause they advocate, by an ill-timed show of eloquence. So far as the writer has had an opportunity of judging, he appears to act upon the advice of an eminent jurist:

Whene'er you'speak, remember every cause

Stands not on eloquence, but stands on laws;

Begin with dignity, expound with grace,

Each ground of reasoning in its proper place;

Let order reign throughout-each topic touch,

Nor urge its power too little nor too much;

Give each strong thought its most attractive view,

In diction clear, and yet severely true.

And as the arguments in splendor grow,

Let each reflect its light on all below;

When to the close arrived, make no delays,

By petty flourishes or verbal plays,

But sum the whole, in one deep, solemn strain,

Like a strong current hastening to the main.

In 1845, Mr. Van Buren delivered, at Albany, an address upon the death of the late President Jackson, and which was published, among others of a similar character.

From 1840 to the present time, Mr. Van Buren has always been an active politician, frequently addressing public meetings. On such occasions, where the powers of an orator have full scope, he has shown himself a ready debater, skilfully seizing the strong points of his adversary, and disarming them of their force by keen satirical strokes. He speaks fluently and cogently, and his style is clear and classical. And although he has yet to acquire that remarkable control of himself for which his father is so distinguished, and which few other men possess, the political opponents of Mr. Van Buren will readily admit, that he is a man of decided talent and handsome acquisitions. 
AMERICAN BIOGRAPHICAL SKETCH BOOK.

\section{JAMES HARPER.}

It is four hundred years since John Faust and Peter Schœffer commenced, in the famous city of Mentz upon the Rhine, the first edition of the Bible that was made with types.' The book was finished in 1450; and soon afterward, copies of it were sold in the market of Paris at six hundred crowns each. Doubtless, if it could be compared with the Illustrated Bible of Harper \& Brothers, it would be found as much below it in accuracy and beauty of manufacture, as it was superior to it in costliness; and six hundred crowns would now purchase at their establishment a better library than the richest princes could afford in the fifteenth century. Ars artium preservatrix is engraved upon the monument to the koster of St. Bavans at Haerlem; but printing is more than the preserver of arts; it is the handmaiden of universal progress, to which we owe all the light and liberty of our time and country; and it has so improved with the ages as to supply the demands it has created. When James Harper and Thurlow Weed worked together in the office of Jonathan Seymour, some thirty years ago, two hundred and fifty impressions only could be produced in an hour; but the Adams press, in a few years, made it possible to reach a thousand; the double cylinder Napier in 1830, three thousand; and the splendid invention of Mr. Hoe in 1847, full twelve thousand sheets in the same time, each four times the size of those printed by Messrs. Weed and Harper in the first quarter of this nineteenth century. It was a great accomplishment for the laborious monk of 1447 to produce a missal in fair characters in a month; but every day there are made in Cliff street more books than the world then 


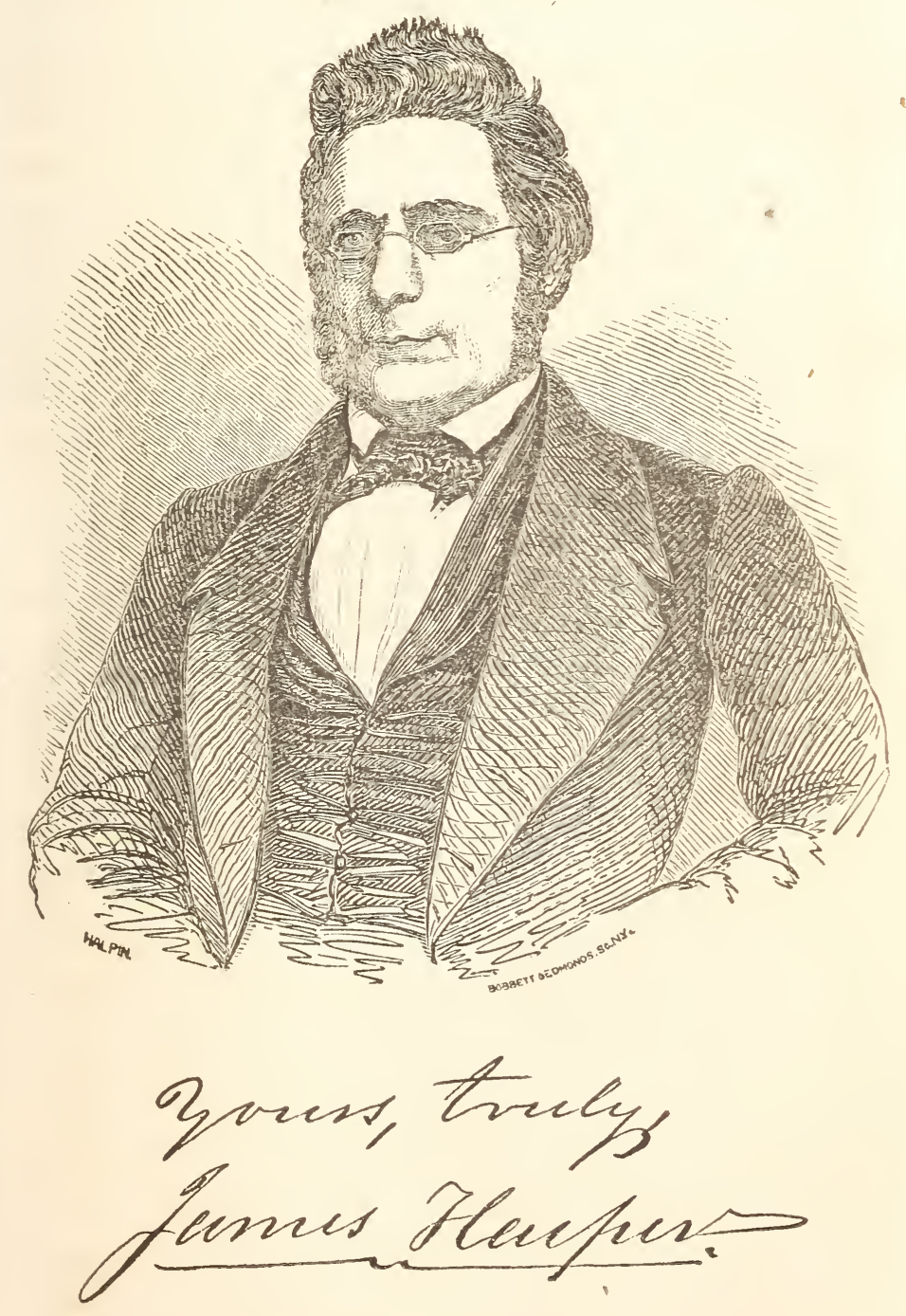



produced in a year. This advance and activity in the CIVILIZING ART has been mainly caused by the application of the first order of practical understandings to the business of publishing. JaMEs HARPER is the head of the largest publishing house in America, perhaps the largest in the world. To the reading part of men, by the Ganges and the Amazon, as well as by the Mississippi and the Hudson, the style of his house is familiar. The brothers, of whom he is the eldest, have made themselves rich, but it is a law of Providence, that whoso worketh for himself wisely, worketh for mankind; and by their energetic and intelligent devotion to business, they have helped on the race with their own fortunes. James Harper has been honored by his fellow citizens; but it is at least questionable whether any other individual of the state, if good accomplished were the measure of popular favor, would stand higher than the late mayor of our great metropolis.

The family of Mr. Harper was eminently respectable in England. His grandfather, a man of education, strong sense, and integrity, came to this country before the revolution, and after passing some time in the business of teaching, settled as a farmer at Newtown, on Long Island, where both the parents of the subject of this notice were born. His father, a fine-looking old gentleman, with a ruddy face, and an eye full of intelligence, who has never been ill a day in his life, is now more than eighty years of age, and lives on his farm near the city, constantly visiting and visited by his children, none of whom ever cost him a blush or a regret.

James Harper was born in 1795, and when about fifteen years of age commenced his apprenticeship at the printing business in the house of Paul \& Thomas, at the corner of Water street and Burling slip, in the city of New York, where he remained six years, in the diligent performance of his duties; acquiring a perfect mastery of his art, and the re- 
spect and confidence of all with whom he became acquainted, by his industry, intelligence, and upright character. A buoyancy of spirit, a natural humor, free from the asperities common to the professed wit, made him a favorite with the young, while his practical understanding and unostentatious piety caused the middle-aged and old to regard him as a youth of promise; and those who have had the pleasure of his acquaintance later in life, will long remember his many pointed yet goodnatured inuendoes, which show that he retains still all his original characteristics.

The example of James led his younger brother, John, to learn the same business; and in 1816 they determined, with some assistance from their father, to establish a printing house on their own account. With two Ramage presses and a few fonts of type, they commenced their career as master printers, in Dover street; and although there was for some time but slight prospect of success, their known industry, skill, and force of character-as in the case of their illustrious exemplar, Franklin-attracted attention. The first book they printed was Seneca's Morals, for Evart Duyckinck, then a leading publisher of the city; and their business so increased, that in 1817 they removed to a larger establishment in Fulton street, where they took as apprentices their two younger brothers, and commenced publishing for themselves, by issuing an edition of Locke on the Human Understanding. The rapid enlargement of their business next led them to 189 Pearl street; then to 230 Pearl street, and in 1825 to 82 Cliff street, where they erected a large printing house, to which they have from time to time made great additions, and where they have now remained nearly a quarter of a century. Previous to their last removal, they took their brothers into partnership, Joseph Wesley in 1820, and Fletcher in 1823. They have since added to printing and publishing, type- 
founding, stereotyping, and binding; so that now they carry on under their own roofs all the branches of the book manufacture.

The limits of this sketch will not admit of any detailed account of their operations. We have mentioned the fact of their being the largest of contemporary publishers; and it will need little confirmation beyond a glance at the descriptive catalogue of their publications, compiled by Mr. Saunders in 1847, which makes a closely printed octavo volume of 160 pages. The cost of their pictorial edition of the Bible was not less than $\$ 500,000$; of their illustrated Shakspeare, $\$ 100,000$; and the publication of either of the great Encyclopedias of Anthon, Brande, Cooper, Copeland, McCulloch, Smith, or Webster, would alone have exhausted the energies of a common house; but they have issued not only all of these, but the complete works of nearly all the great classical authors of our language-Shakspeare, Massinger, Addison, Dryden, Johnson, and Burke; the historians, Plutarch, Livy, Rollin, Gibbon, Robertson, Hallam, Russell, Mosheim, Alison, Thirlwall; and, indeed, the master works of genius, reflection, and observation, in nearly every department of letters that has been invaded by the human mind.

It has sometimes been said that this great house is a manufacturing rather than a publishing onemeaning that they have done comparatively little in original literature-but the opinion is most erroneous; no house on this continent has paid so much to authors, as will be evident when it is remembered that they are the publishers of Prescott and Sparks, of Webster and Anthon, of Stephens and Olin, of Mrs. Sigourney and Mrs. Sedgwick, of Durbin, Fisk, Upham, Paulding, Simms, and, to a greater or less extent, of almost every writer in science, or historical, metaphysical, romantic, or general literature, that has been contemporary with them in America. 
The enormous extent of their business may te judged of by the fact, that their issues have amounted in a single year to between two and three millions of volumes of various works-their weekly expenditures to from four to five thousand dollarsand the number of their employees to from four to five hundred persons.

We have spoken of the history of the house, because James Harper's life has been in so eminent a degree identified with it as the senior and most active partner.

But James Harper is a man of original, strongly marked, and elevated character. His quick apprehension and close observation; his travels in foreign countries, (in which his wife and son accompanied him, as well as his intimate friend, the lamented and distinguished President Fisk, of the Wesleyan university,) and his long and familiar acquaintance with the most distinguished men of letters, with whom he has beèn brought in contact in the course of his business experience, added to his life-long, high morality, and consistent piety, render him one of the strong pillars and conservators in society. And it is a happy illustration of that prescience of the popular mind, which detects moral and intellectual worth by a sort of intuition, that the great qualities of a person so unobtrusive, who never mingled at all in the storms of public controversies, should have been felt and acknowledged in so signal a manner as Mr. Harper's were by the citizens of New York in 1844.

The mayoralty of New York is an office in importance equal to that of the chief magistracy of most of the states, and superior, perhaps, to that of any other city in the world, as most of the great cities of Europe are divided into comparatively small municipalities, with distinct governments. The affairs of New York had been managed in turn by the leaders of the two great rival parties, 
and the people grew anxious for the selection of a magistrate unconnected with the old organizations, whose personal character should be an assurance to them of ability and fidelity. The lax administration of the laws connected with foreign emigration, led to the formation of the American party; and in the year referred to, that party nominated for this office, with great unanimity, Mr. James Harper. We have been particular in stating the circumstances, because the nomination and election were in an extraordinary degree tributes of PERSONAL RESPECT AND CONFIDENCE, bestowed upon a citizen who had never mingled in political affairs, and known to the electors only for his abilities and honorable private life. Mr. Harper conferred with his brothers upon receiving the nomination, and would have declined, having no ambition for such distinctions, and but little confidence in the favorable auguries of his friends; but his scruples were overcome, and, in the face of the most energetic action on the part of the old parties, thoroughly organized and with popular candidates, he was triumphantly returned by a majority of from five to six thousand votes.

NoтE.-We have another fact to add to this brief history, and in writing it we may invade more than is fitting the sacred privacy of domestic life. The successful and happy career of Mr. Harper has recently been interrupted by an irreparable loss, in the death of one of the most admirable wives that ever made an earthly home a type of the heavenly. Mrs. Harper, formerly Miss Arcularius, of a family distinguished in the history of our great metropolis, died after a painful illness, borne with Christian resignation, on the 4th of March, 1847; and after an appropriate funeral discourse, by her pastor, the Rev. Mr. Crawford, of the John street Methodist church, was buried in the Greenwood Cemetery. Her memory is cherished by many who had been relieved from suffering by her judicious munificence, or been guided and encouraged in the pleasant ways of piety by her beautiful instructions and example. Her character presents a rare combination of moral and intellectual excellencies; and no felicities which the world can bestow can renew to her husband and children the happiness which with her has passed from earth to heaven. 


\section{ROBERT SEARS.}

The following notice of this worthy man, is condensed from a memoir by George Lippard, Esq.:

The glories of this world are not altogether found upon the kattle-field, amid the bones and skulls of carnage. There is one spectacle, upon which the angels may look with reverence. It is not the warrior, crowned with the laurels of slaughter, guiding his war-horse over heaps of dead; nor the statesman, convulsing nations from the tribune of the senate, so that he may reap his harvest of fame and gold, from the very baseness of political strife; nor is it the merely rich man, whose only religion is to accumulate and gather fresh stores of gold, to sink him the deeper in a forgotten grave.

It is none of these. It is a solitary man, toiling from the shadows of obscure life into an eminence of usefulness; from the darkness of hardship and the work-shop of toil, into the sunshine of a great and benevolent enterprize.

We will look upon a man of this class.

It was in New York, in the time of the cholera, when the school-houses were turned into hospitals, and the grave-yards could not hold the dead, when the plague, and the panic born of the plague, smote its thousands every day, and summed up its tens of thousands every week, that a young man was toiling steadily, in the shadows of a printing office.

Were we to look upon him in his toil-while the hot air of the pestilence came like a furnace blast through the unclosed windows of the work-shopwe should not so much regard his plain dress, his humble position, his long days and nights of labor, as look with interest upon that manly though meek face, enlivened by an eye that already flashed with 


great enterprize, and mellowed by the glow of a soul full of good to the whole human race.

The history of the young mechanic would fill us with strong interest for his fate.

Born in St. Johns, New Brunswick, on the 2sth of June, 1810, he had struggled up, through the laborious scenes of seven years' apprenticeship, and, with a mind strengthened by a solid English education, always kept in view the great end of his life. That hope, to convert the gloomy press into an engine of immense good, to make it a messenger of knowledge to many hundred thousand homes, and have the chlldren of a future age say of him, this was not the Hero of the Sword, but the Apostle of the Printing Press.

How did he accomplish it? In the spring of the year 1832, he started in business, and supported his family by printing cards and circulars. The cholera came, and with it the universal panic and the tottering of all public confidence. He was forced to close his shop, and take to his journevman life again.

Still in this time of unobtrusive toil, a great vision of usefulness opened upon him. While working at the press and case, he determined to become a publisher. Without capital, without the praise of pompous reviewers, without friends-save the generous few attracted by his unyielding virtues-he made up his mind to be the publisher of useful books.

He calmly laid his plan, and in the silence of the night, after the day's work was over, matured it into shape. He determined to pursue the only legitimate method of publication-to advertise his works, place them thoroughly before the people, and leave the people alone to decide on their merits.

The cholera passed, and he resorted to his press and types once more. In the short intervals snatch- 
ed from severe labor, he compiled a chart, entitled, " The world at one view," placed it in type, published it in one broad sheet, advertised it for twelve and a half cents, and was rewarded by a sale of about 20,000 copies.

This was a good beginning. The Family Receipt Book was next published, met with a rapid sale, and the young publisher began to widen his plans, and concentrate his resources for greater efforts.

Undismayed by the sneers of the idle and thoughtless, the cold approbation of doubtful friends, he then projected a work in three large volumes, copiously adorned with engravings, and entitled, Pictorial Illustrations of the Bible. This required immense labor, and, more than capital, the confidence of the public. The young publisher had it. For pressing steadily onward, after an interva. of several years, he issued this work in the fall of 1810 -risked his all on it, staked every cent in advertising it to the whole union, and sold 25,000 copies. Decidedly a triumph for the journeyman printer of yesterday!

Then he began his grand mission of teaching to nations and to man, by the medium of books, intended to be useful and popular, and made to speak through the eye to the heart, by appropriate and vivid pictorial illustrations.

It is that branch of art known as wood engraving, which, by its peculiar qualities, especially presents itself as a great medium of pictured thought. It is cheap, available, effective. It can be printed with the pages of a book, and with the same press. It is capable of rich lights, and deep shadows, far beyond the power of copper or steel. Robert Sears has called to his aid this branch. of art, and showed its powers in his Pictorial Illustrations of the Bible.

The name of Robert Sears began to grow in the minds of the people, and the homes of the land learned it by heart in his numerous works. 
We might draw large deductions from the life of Robert Sears, but that life speaks for itself. It says to every young man in the Union, behold the fruits of unswerving integrity, unstained morals, unyielding enterprize. It shows, conclusively, that one man, aided by his own hand, may emerge from a printing office, and gather the harvest of his long years of toil, in the approbation of a whole people. It asserts, that with no capital, but a common school education, a firm heart, and an honest pair of hands, a young man may carve himself a glorious way to usefulness and fame.

Mr. Sears published several months ago his greatest work, The Pictorial Domestic Bible. We cannot but wish him success in it, for his whole heart is engaged in the enterprize; he has brought the honestly acquired wealth of years to the task, and nerved his soul to its successful issue. It is a book for the pulpit, the home, the closet. In it we behold the Bible of our faith, glowing with pictures that reveal to us, at a glance, the life, the history, the poetry of the Bible. It is a glorious field - a holy task:

Chance may produce a notorious, but never yet did chance produce a gREat man. No man can be wise or good without labor. Robert Sears is a firm believer in this stern truth, and upon this basis, he has arisen to usefulness and fame. He is above all sect or party. His creed is simple - it can be understood at a glance, for it is Love.

We must confess that this Robert Sears is no ordinary man. His books have become household treasures in the towns and farms of New England. The printed results of his research and industry, have enlightened the log cabins of the west, and penetrated with benevolent light, the rude homes of Texas. Throughout Canada, Nova Scotia, New Brunświck, and the British possessions in North America, he is widely and favorably known as the 
pioneer of a better age, in this home literature, adapted for the sanctities of the fireside.

Even the queen of Great Britain has welcomed his labors with royal applause, and stamped his books with more than royal approbation - with the good wishes and the smile of a woman and a mother.

It must be gratifying to Mr. Sears to reflect that the intelligence of the kind wishes and deserved approval of Victoria, was conveyed to him in an official letter, written by her request.

Ane effective contrast might be drawn between Robert Sears and his granduncle, the Rienzi of the revolution, and who was by his opponents nick-named King Sears. The latter is seen in the dawn of the revolution at all points, now breasting his soldiers on New York battery, now scattering into atoms the infamous tory press of Rivington, now boldly advocating the assembling of a continental congress. A sturdy man, nursed into familiarity with danger on the broad ocean, he gathers the people, becomes their oracle, prepares the way for Washington and the signers. Altogether, such a man as the Almighty sends to do a great work, and then retires from the stage.

The descendant, Robert Sears, emerges from the shadows of a printing office, becomes the publisher of a people, and sends copies of all his works to Queen Victoria, grand-daughter of George the III, whom King Sears successfully resisted on all occasions. The sovereign of the same nation, which opposed our entrance into the family of nations, is happy to receive American books from a descendant of a revolutionary hero. 


\section{WALTER FOLGER.}

This remarkable man was born at Nantucket, Massachusetts, June 12th, 1765, and is now in his eighty-third year. His paternal ancestor, John Folger, came from England, in 1636, and settled at Martha's Vineyard. In 164t, Peter married Mary Morrell, a waiting maid, by whom he had eight children. In 1662 , he removed to Nantucket, where he had another child, named Abiah, who was the mother of Benjamin Franklin.

Walter, the subject of this sketch, during the brief schooling he received before the revolution, never even saw a dictionary, but heard of a grammar book. In 1783, without any instructor, he made considerable proficiency in algebra. He was also a self-taught French scholar. Having acquired a knowledge of astronomy, in 1790, he completed and set in operation one of the most wonderful pieces of mechanism of the age. It is an astronomical clock, which, from that period to the present hour, has kept time according to astronomical calculations. It is made of brass and steel. It keeps the date of the year, and the moon's nodes round the ecliptic. The sun and moon rise and set precisely in accordance with those in the heavens, and it shows the sun's place in the ecliptic. The wheel that keeps the date of the year, revolves once in one hundred years, remaining still ten years, and at the expiration of each ten years, it starts regularly one notch. No other clock of this kind has ever been heard of. In 1817, Mr. Folger made, entirely himself, a large telescope, which, for its size, was of much greater power than Herschell's. A self-taught lawyer, he practised in Massachusetts for many years. 


\section{REUBEN HYDE WALWORTH.}

Chancellor Walworth is the man who more than twenty years ago, prophesied that "the time would come when men would as soon be found engaged in poisoning their neighbors' wells, as to be found in making or vending intoxicating liquors, to be used as a beverage in health." His exertions in the glorious cause of temperance alone, have entitled him to a fadeless wreath, that will hold its greenness in the lapse of ages, and freshen through eternity. His efforts to crush the serpent which was converting the bloom of Eden into a wilderness of woe, have caused his name to be wafted abroad on every breeze that fans the cheek of the philanthropist.

William Walworth of Groton, in Connecticut, his paternal ancestor, was the head of the family in this country. He was a farmer, and came from the neighborhood of London shortly before the close of the seventeenth century, with Governor Fitzjohn Winthrop, and went on to Fisher's Island, to take charge of the governor's farm there. He married Abigail Seaton, who came over from England at the same time. While Kidd and his associates were carrying on their piratical operations on the coast, William Walworth and his family were driven from the island. He then purchased a farm at Groton, but died soon afterwards, and before he had paid for his land, leaving three sons and two daughters, all minors. But his widow, a woman of great energy of character, and who had received a good education before she had left England, was enabled, with the assistance of her children, to pay for the farm, and to bring up her family comfortably upon it.

John Walworth, the youngest son of William, 
also a farmer, was the grandfather of the subject of this sketch. He married Sarah Dunn of Newport, Rhode Island. He died about 1750. He left nine children, of whom Benjamin Walworth, the father of $R$. Hyde, was the youngest, he being under five years of age at the time of his parent's death. John resided for a time on Gardiner's island, afterwards at Horseneck, and finally settled in his native town. In 1774 he received a commission trom Gov. Law, appointing him an officer of cavalry. He died at Groton, without much property, and leaving his children dependent on their own exertions for a support.

Benjamin Walworth was born at Groton in 1746. He learned the trade of a hatter, and worked for several years at the business, during the early part of his life. At the commencement of the revolution, he was adjutant of Col. Stevens's regiment, and was at the battle of Thite Plains. He was afterwards at Minisink, at the time it was destroyed by the Indians under Brant, and narrowly escaped the massacre which followed. He was quarter-master of the detachment which pursued the Indians, and was sent back to procure ammunition, only about an hour before the detachment fell into the ambuscade. His light fowling piece, which he gave to one of his companions in arms when he left the detachment, and which saved the life of its temporary possessor, is still preserved by the family. Soon after the close of the revolution, Benjamin was engaged in merchandize in Dutchess county, with Philip Hart, and he subsequently established another store at Schaghticoke, in Rensselaer county. After the final cessation of hostilities in 1782 , he returned to Connecticut, was married, and two or three years afterwards relinquished his business as a merchant. He then took a farm at Bosworth, New London county, where he resided until 1793. He afterwards purchased a farm at Hoosick, New York, and carried 
on the business of farming in that town until his death in 1812.

The maiden name of the mother of R. Hyde, was Apphia Hyde. She was a daughter of the Rev. Jedediah Hyde, a seperatist clergyman of Norwich, Connecticut. He was a great-grandson of William Hyde, (one of the thirty-five original proprietors of Norwich,) who came from England, and who was one of the first settlers of Hartford. Her mother was Jerusha Tracy, granddaughter of John Tracy, another of the original proprietors of Norwich, and a granddaughter of Mary Chilton, who came over in the May Flower, and married John Winslow of the Plymouth Colony. (Lieut.-Gov. John Tracy of Chenango county, and Albert H. Tracy of Buffalo, are of the branch of the Tracy family.) John Walworth, the oldest brother of the chancellor, was a major in the army of the United States, during the last war with Great Britain, and distinguished himself at the taking of Little York and Fort George. At the former place he led the advance, and was by the side of Gen. Pike when that brave officer was killed. He was himself wounded at the same time. At the close of the war he settled at Plattsburg, and was afterwards elected clerk of Clinton county. This office he held until his appointment as assistant register of the court of chancery, and which he retained until his death in 1839 .

James Clinton Walworth, the second brother, a farmer, resides in Otsego county, where he has been county judge for many years. The third brother, Jedediah H., was a lawyer, and died about twenty years ago. The fourth brother, Benjamin, is a physician of eminence, at Fredonia, in the county of Chautauque, and was also a county judge for many years. The younger brother, Hiram, the late assistant register, is now living at Plattsburg. The youngest sister married Capt. C. T. Platt, of the United States navy. There are also three other sisters who 
are married, and who reside in the county of Chautauque.

R. Hyde Walworth, the chancellor, was born at Bozrah, a part of the old town of Norwich, in Connecticut, on the 26th of October, 1789, and, with his parents, removed to Hoosick, Rensselaer county, New York, in 1793. He was brought up to the business of farming. He had no advantages of education, except what he obtained at a common village school. He has repeatedly said, that he has all his life felt the loss of a liberal education, and that he could have been a much more useful member of the community, had he enjoyed the advantages in this respect, which are possessed by so many of the young men of the present day. So anxious was he to get an education, that at the age of twelve he went from home, and worked through the winter, mornings and evenings, for his board; that he might have the advantage of a better common school than that in the vicinity of his father's residence. At the age of sixteen he was himself a teacher in a village school, during the winter months. He was also engaged in the same employment during the following winter.

In the summer of his eighteenth year, he met with an accident which incapacitated him for farming, and changed the whole course of his life. In drawing a load of grain, he overturned it down a precipice. Being on the top of the load, be fell with it; by which means one of his ancles was so much injured, as to make him lame for several months. In consequence of this accident he was obliged to quit farming. He then went into a store for a short time, as clerk. While there, he commenced the study of law, with a lawyer residing near the store. He afterwards entered the of fice of the late John Russel, of Troy, who was an excellent jurist and a most worthy man. At the age of twenty, Mr. Walworth was admitted an at- 
torney of the court of common pleas. He then formed a copartnership with the late Judge Palmer who was an attorney of the supreme court, and went into practice with him at Plattsburg, in 1810.

In the spring of 1811 he was appointed a justice of the peace for Clinton county. About the same time, Governor Tompkins appointed him a master in chancery. He was also admitted to the supreme court during the same year.

In January, 1812, he was married to Miss Maria Ketchum Averill, of Plattsburg, she being then a few days over sixteen years of age. They have had six children-two sons and four daughters-all of whom are still living, except one daughter, who died at the age of five years.

A week after the birth of his first child, in December, 1812, he had the misfortune, by an accidental fire, to lose his house, which he had built the preceding year, and from which he himself narrowly escaped with his life. Being engaged in throwing from the upper window the trunks of some officers, who had gone on a furlough, and left their baggage with hirn for safety; he remained until the fire broke in upon him, by which he was considerably burnt. He succeeded, however, in making his way through the flames to the foot of the lower stairs, when he fainted, and was carried out by some friends who happened to be there. By this fire, he lost about the whole of the avails of his previous professional labor, which he had invested in the house. But as a quaint writer has remarked, "as it would be harmful to the earth, if it was ever summer and sunshine, so would it be prejudicial to man if fortune was ever smiling. It is necessary for our contentation that we should now and then be reminded by a fire or a blast, that all we possess is precarious." But this misfortune did not deprive Mr. Walworth of his energy. Having many friends, who gave him sufficient employment, 
he soon recovered from his loss. In addition to this, by the death of his father, he came into the possession of a small patrimony.

In $1<13$, he was appointed one of the aids to Major General Mooers, who had the command of the United States forces during the siege of Plattsburg, in Sept., 1814. The latter, at the time of the siege, assigned to Mr. Walworth the duty of acting adjutant-general of the forces under his command. The whole of his division, except the brigade in Columbia county, were called out at that time, but only three regiments arrived at Plattsburg before the retreat of the enemy. On the evening of the 5 th of September, the head quarters of Gen. Mooers were at Beekmantown, about five miles and a half in advance of the fort at Plattsburg, and the enemy, who were advancing upon the place in great force, had encamped for the night, two or three miles further north. Between nine and ten o'clock at night, upon consultation with Gen. Mooers, the latter concluded to send an order to Brigadier General Macomb, who was in command of the regular troops in the fort at Plattsburg, to detach two hundred infantry and a company of light artillery, and to send them out early in the morning to sustain the militia, and the resistance it was intended to make to the advance of the enemy. Mr. Walworth accordingly made out the order, and rode with it to Plattsburg, arriving at the quarters of General Macomb about midnight. From thence he went to his own deserted home on the north side of the river, in the village, and slept upon the floor until daylight; when he mounted his horse and rode back to the head quarters of General Mooers, arriving there about sunrise. In the mean time, Major (now Gen.) Wool, having been detatched with two hundred infantry, had arrived at the same place. They were posted about half a mile in advance of Gen. Mooers' head quarters. Information was soon 
brought to the general, that the enemy had broken up their encampment and were advancing. Gen. Mooers thereupon ordered Mr. Walworth to take a detachment of the militia, and to proceed to occupy a bridge across a small stream, in front of the enemy's advancing troops, so as to retard the progress of their artillery. He did so, and the action on that day commenced with the detachment under his command, when the fighting became general. The American troops fell back gradually to Plattsburg, making one or two stands, at favorable positions, where the enemy suffered severely. In marching through the village to the forts, on the south side of the river, they passed Maj. Walworth's house, in front of which there was a skirmish, which left many marks of balls on the building, many of which are still visible. He had some days previous sent off his family to the village of Penn, about twelve miles south of Plattsburg. After the retreat of our troops across the river, his house remained in possession of the enemy until they left, after the battle of the 11th. It had also been in their possession three years before, when they destroyed the arsenal, barracks, \&c.

A. C. Moore, Esq., in an anniversary address delivered at Plattsburg, Sept. 11, 1843, thus alludes to the battle:

"Meanwhile Gen. Mooers, with the aid of Maj. Walworth, our present chancellor, Col. Miller and other officers, of the 4 th brigade, had succeeded in rallying a portion of the militia, which being ordered to join Maj. Wool, with his detachment, awaited the approach of the enemy at Calver's hill, about four miles from Plattsburg. This commanding position was maintained with so much obstinacy, as to compel the enemy, after attaining the summit of the hill, to retire to its base, with the loss of Lieut. Col. Wellington, who fell while gallantly leading the $3 \mathrm{~d}$ Buffs to the charge." 
Here it was that Capt. Leonard, with his two pieces of light artillery, arrived to take part in the action. At this point, one of the finest specimens of discipline ever exhibited, was shown by the British troops on the occasion of the opening of Capt. Leonard's battery upon them. The company to which I was attached, formed a part of the left of our little army, and was on the rise of ground west of the road leading from Halsey's corner to Isaac C. Platt's, about midway between the artillery and the head of the British columns, and the whole scene was open to our view. Here, at Halsey's corner, was a battery of two field pieces, so perfectly masked by a party of infantry, that the enemy were probably not aware of it until it opened upon them. There was a dense column of men, with a front equal to the width of the road, and extending half a mile in length, pressing on with a buoyancy and determination of spirit, confident that they would be enabled to walk into our works without opposition:

March-march-march !

Earth groans as they tread;

Each carries a skull, Going down to the dead.

Every stride-every stamp Every foot-fall is bolder;

' $\mathrm{T}$ is a skeleton tramp,

With a skull on his shoulder.

But ho! how he steps,

With high, tossing head,

That clay covered bone,

Going down to the dead.

Suddenly, with the noise of thunder, the sound of cannon came booming through the air. It sent forth a round shot which took effect near the centre of the front platoon, about breast high, and plowed its way through, sweeping all before it the whole length of the column, opening a space, appa- 
rently several feet wide, which, however, was immediately closed, as if by magic, and the column pressed on, as if nothing had happened. A second shot was fired, with like effect and similar consequences; but when the third discharge came, with a shower of grape shot, there was a momentary confusion. Immediately, however, the charge was sounded by some dozen British bugles, which, through the clear and bland atmosphere of a bright September morning, was the most thrilling and spirit-stirring sound that could greet a soldier's ear. In an instant of time, the men forming the advance of the column, had thrown their knapsacks on each side of the road, and bringing their pieces to a charge, advanced in double quick time upon our miniature battery."

Major Walworth again distinguished himself in the battle of the 11th of September, 1814, with the brigade of the enemy which crossed the Saranac at Pike's cantonment, to get in rear of the fort.

Speaking of the result of the naval engagement on Lake Champlain, on the same day, which was witnessed by the contending thousands on shore, Mr. Moore remarks:

"When the firing ceased upon the lake, Major Walworth, (who had been despatched early in the action, by Gen. Mooers, from the plain, to station a portion of the Vermont militia on the Saranac, and learn and report the result of the naval engagement,) was seen through the thin trees, returning with his horse, at the top of his speed, and waving his hat. Gen. Mooers well knew the joyous signal, and three deafening cheers arose from the line of the gallant New York militia, and spread like wildfire on the right, among the Green mountain loys."

The whole period during which Major Walworth served, did not exceed fifteen days; but it was full of incident. He has never been ambitious of military fame, but as the above particulars form a part 
of the history of the country, they.could not well be omitted. During the time, his law office was burnt by hot shot from our artillery, in driving the enemy out of the village on the north side of the river.

In 1818 a law being passed for the appointment of a supreme court commissioner for the western part of the state of New York, Major Walworth obtained that appointment. In the spring of 1821 he was elected to congress from the double district, comprising Washington, Warren, Clinton, Essex, and Franklin counties. Although the political majority in the district was about 1,800 the other way, the year previous, he was elected by about 1,500 majority, and his colleague, Gen. Pitchin, by about 900 majority over their opponents. While in congress he served on two important committees, viz.: the committee on elections, and the military committee, and in consequence of the feeble health of D. Eustis, chairman of the latter committee, most of the duties of preparing reports and bills, devolved upon Major Walworth. It was during the first session of the 17th congress, in the winter of 1821 and 1322 , that he first introduced the proposition to abolish the whiskey ration for our regular soldiers, and which was carried into effect by Gen. Cass, when he was at the head of the war department some years afterwards. But at the time Major Walworth introduced the resolution of inquiry in January, 1822, which was some years before the organization of temperance societies here, it was impossible to obtain a favorable report upon the proposition. Indeed it was only by great exertion that he was enabled to carry the resolution of inquiry, it being then considered by most men as perfectly visionary to suppose that an army could be kept together without the spirit ration. Having declined a reelection to congress, which would have been certain, he was, in 1823, appointed by Gov. Yates, circuit judge of the fourth circuit. In the fall of the 
year he left his residence at Plattsburg, where he had lived thirteen years, and removed to Saratoga Springs, his present residence.

The most important trial before him, as circuit judge, was that of the three Thayers, for the murder of John Love, in the spring of 1825 , and who were all convicted and hung upon the same gallows; and the trial of Stephen Videte, in Franklin county, for the murder of Fanny Mosely, both of which trials were reported. While circuit judge, he made it a practice to interchange with the other judges, so as to hold only one circuit in the different counties of his own circuit, in each year. In this way he held courts in more than twelve of the counties in the state, during the five years he was on the bench of that court.

In April, 1828, upon the resignation of Chancellor Jones, he was appointed to the office of Chancellor. It is but justice to Major Walworth to say, that he would not permit himself to be appointed over the heads of the then justices of the supreme court, without their consent. Mr. Justice Woodworth lacked but a few months of the age of constitutional disability to retain the office, and was not, therefore, consulted. Under these circumstances, the poor boy who toiled during severe winters to pay for his schooling, entered upon the arduous and responsible duties of CHANCELLOR of tHE state of NEW YoRK!

How faithfully those duties have been discharged, the numerous commendations from men of all parties, will be the best answer. The twelve volumes of the reports of his most important decisions in chancery, and his opinions in the court for the correction of errors, which are found scattered through the thirty-five volumes of Wendell's, Hill's, and other reports, will enable the profession to form their own opinions on the subject. As a solitary proof, however, of the estimation in which his 
talents are held, we would call attention to his recent appointment by the legislature, as one of the commissioners for a revision of the code of the statebut which honor, in an interesting and instructive letter, highly creditable to himself, he thought proper to decline. A highly respectable journal, in admitting the validity of the reasons of his resignation, said: "The liberal education, the real knowledge, and the views and purposes of reform, which the chancellor was known to entertain, afforded great promise of favorable results. He unites to great industry and clear knowledge of our law, a more thorough acquaintance with the judicial systems and legal polity of other nations, than falls to the lot of many of the bench and bar."

At the organization of the State Temperance Society, in February, 1829, he was appointed its president; and he continued to be elected to the same station, until his appointment as president of the National Temperance Union.

In 1835, he was honored with the degree of LL. D., by the college of New Jersey, at Princeton. He subsequently received the same honor from Yale college, at New Haven-both of which were as unexpected as they were unsought.

In 1840 , he was elected a corporate member of the board of commissioners for foreign missions; and he has attended the annual meetings of the board ever since.

Upon the death of the late Judge Thompson, a majority of the New York delegation in congress, presented the chancellor's name to President Tyler, for the vacancy upon the bench of the United States supreme court. His name, after the rejection of Mr. Spencer, was accordingly sent to the senate. Political considerations, however, induced the majority of that body to postpone the appointment, until after the result of the presidential election was known. At the commencement of the 
next session of congress, a renewal of the nomina. tion being deemed necessary by some of the senators, the name of the chancellor was again sent in; and it is well known that every member of the legislature of New York, of both political parties, joined in a request to the senate to confirm the nomination. But for some reason which has never been explained, the senate neglected to act upon it, until the president became satisfied that it was intended to postpone it beyond the session; whereupon the nomination was withdrawn, and the name of Chief Justice Nelson substituted.

In his domestic relations, Chancellor Walworth has been eminently blessed. As has been previously stated, he was united to Miss Maria K. Averill, in 1812, when she was little more than sixteen years of age. Entering upon the duties of a mother and mistress of a household, at an age when most are occupied with their sports or their school, there was an early development of those traits of character for which she was distinguished in later life; and when the entire charge of the domestic arrangement of a large family was necessarily committed to her, she was found fully prepared for it. She, with her husband, joined the presbyterian church at Plattsburg, in 1821, and if there ever existed an humble practical Christian, she was one. Her actions proved that she believed what she professed. But on the 24th of April last, a voice said, "come up hither," and the devoted wife and tender mother exchanged the tears of earth for the smiles of heaven. Her dying scene was worthy of the life that she had lived; it was a scene of triumph-there was glory in her last words-in her last look. She clung to the cross as her only refuge-clung to it with a tenacity which brought perfect assurance to her spirit, and kindled a glow of rapture in her countenance while she lay amidst the shadows of death. They sung at her bedside, 
"Rock of ages, cleft for me," and her serene and triumphant smile showed that she could appreciate it. It was no common death that she died; and all who looked on felt that there was in the scene, an unwonted commingling of heaven with earth.

How happy will be the meeting of the bereaved family with her again in that better world-

Where every severed wreath is bound, And none have heard the knell

That smites the soul in that wild soundFarewell, beloved, farewell.

\section{DAVID B. OGDEN,}

One of the patriarchs of the city of New York, was born at the beautiful village of Morrisiana, Westchester county, on the 31st of October, 1775 His father was Samuel Ogden, of New Jersey. His mother was a sister of the late celebrated Governeur Morris, whose name figures so largely in the history of this state.

The subject of our notice was educated at Philadelphia, and received his degree of bachelor of arts in the University of Pennsylvania, about the year 1792. He studied law in the state of New Jersey, and was admitted to the bar in the fall of 1796 . In November, 1803, he removed to New York city, where he has resided ever since. He married in 1805. His amiable partner was a native of New Jersey, and has been dead for some years. No couple ever lived more happily together. Perfect bliss cannot be known in this world; yet if there can be a heaven upon earth, it is where strong, deep, all-hallowing household love is the sunshine 11 
that pervades every thing within its charmed circle of union. Yet,

There is no union here of hearts,

Which has not here an end.

But as the glorious summer comes back again, recalling from the earth the flowers and leaves, and spreading over the sky the sunshine and the blue; so will the dawning of another life restore to the mourner, the bright objects of love and affection, giving the "sunshine of faith, and the blue sky of peace."

But although the wife of his youth has gone, he has still rich blessings left to him in his children, all of whom are above reproach. Truly dutiful, affectionate children, are the real gold and silver of life, and without domestic riches, all else is dross.

In 1814 and 1837, Mr. Ogden represented the city of New York in the house of assembly, and on both occasions he acquitted himself to the satisfaction of his constituents. He is a man of sterling principle, liberal feelings, and amiable disposition; and during his extensive practice, has acquired a great knowledge of human nature. Of his professional life there can be but one opinion. He has talents of the highest order, and at the bar he has but few equals; and it is not necessary to say, that for a long period he has been at the head of many of the movements in the city of New York, for the promotion of objects of benevolence.

As the full moon sinks slowly beneath the western waters, so may he, sweetly and calmly glide in peace to the land of sleepers, and awaken in that region where the Savior is the only advocate, and where reigns universal the law of love. 


\section{EDWARD C. DELAVAN.}

Whose eye does not brighten at the mention of this name? and who does not exult at the fact that "this man is ours?" From the age of five to the present time, his life has been one of toil. Nearly twenty years ago, he grasped the banner of temperance ; and without a thought of retreating, he has been pressing forward, through sunshine and storm, devoting his energies and his wealth to the advancement of the glorious cause. No spoiled harvests and desolated countries have marked his path; but the waste places of the heart have been made to bloom, and "roses have sprung up in the place of ashes." His circulation of more than twenty millions of temperance documents, will give a faint idea of the extent of his labors of love. His extreme modesty would be wounded by an enumeration of other deeds, equally redounding to his honor. He has in truth, from the beginning, been a laborer in every sense of the word. While many were content with talking, he was acting. When others said, "go on," he said, "come on." It has been well remarked that example is a living lesson. It is like statuary. It is sculptured into form. Every action has a tongue. Words are but articulated breath. Deeds proclaim what is within.

In the first temperance convention ever held in this country, for discussing the total abstinence question, which took place at Albany, in 1834, Mr. Delavan introduced a preamble and resolution, warmly recommending a total disuse of intoxicating liquors, as the only effectual means of reforming the drunkard. The resolution was strongly, and no doubt conscientiously opposed, on the alleged ground, "that the Scriptures permit and sanc- 
tion the use of (intoxicating) wine; also, that the Savior not only used it, and consecrated it, but that he manufactured it." So great was the interest felt in this discussion, that over a hundred thousand copies of a document containing the speeches were circulated. The result was, that many good men began earnestly to examine their Bibles, and history, to ascertain whether it was really intoxicating wine that the Savior made at Cana, and which he used as a symbol of his blood at the institution of the supper. A very general excitement was produced by the agitation of the question-the opposifion appeared to triumph, and for a time the public discussion of the subject was suppressed.

Not discouraged, however, Mr. Delavan, both at home and in foreign countries, applied himself with unwearied perseverance, and regardless of expense, to ascertain, if possible, through the agency of learned men, the kind of wine the Bible approved of, as a beverage in perfect health, as well as the character of the fruit of the vine, used by our Lord at the institution of the supper. How far he succeeded, the first number of the Enquirer, published by him at Albany, in 1841, made manifest. In addition to fifteen argumentative letters, addressed by Mr. Delavan to the Christian public, it contained a mass of irresistible evidence, from the greatest and wisest men of the age, in favor of total abstinence; and proving, beyond the possibility of doubt, that the liquor sold as wine in this country, whether for common or sacramental use, is not wine, in the scriptural sense, and often not the fruit of the vine at all, but a compound of distilled spirits and the most poisonous drugs. More than thirty thousand copies of the Enquirer were gratuitously circulated by Mr. Delavan, among clergymen, editors, postmasters, etc. The demon alcohol trembled on his throne, and thrust forth his forked tongue; but the truth went forth clothed in triple mail, and the 
gates of hell did not prevail against it. The formidable array of facts, fell like red hot shells into the powder magazine of the enemy, and the errors of centuries were exploded.

The second number of the Enquirer vigorously followed up the attack; and long before the appearance of the fourth number, in 1846, multitudes of churches had substituted the unintoxicating fruit of the vine, for distilled spirits and drugs, and the colors of total abstinence waved in triumph through the land.

In exposing the unrelenting inhumanity of avarice, it could not be expected that the subject of this brief memoir would escape the difficulties with which benevolence and philanthropy must always struggle. On the contrary, his constancy has been fully and severely tried. But of the triumphant verdicts in his favor, when sued for speaking the truth, and of numerous other incidents of his career, it is not now necessary to speak. It is sufficient to say, that although now in his fifty-fourth year, he is as arduously as ever engaged in the good work, and will continue so, until he shall be called to drink of the crystal waters of the river of life, that flows through the paradise of God. In a few years the fallen leaves will rustle over his last resting place, but "his works will follow him." Blessed are the dead that die in the Lord, and blessed also are the valiant who have lived in the Lord. The cause he advocates must prosper, for it is founded upon a rock. "It is a portion of God's empire, and from his throne he will defend it. The angels have their charge over it. The banners of archangels are on its side; and from sphere to sphere, through the illimitable ether, its triumph is hymned by harps which are strung to the glories of their Creator." 


\section{WILLIAM G. ANGEL.}

Mr. Angel is a native of Block Island, in the state of Rhode Island. He was born on the 17th of July, 1790. His parents were Quakers, and natives of New London county. The subject of our notice was the youngest of ten children. His father, whose means were very limited, removed to Otsego county, New York, in 1792, that portion of the state being then a wilderness, owing to which William could have no advantages of education. His sisters taught him his alphabet, and to read and write. He afterwards, for about, in the aggregate, a year, attended a summer school, taught by very ordinary teachers. He worked on a farm with his father until he was nineteen years of age. At that period he became acquainted with the late William Davis, Esq,, attorney at law, of Cooperstown. This gentleman hired him as a domestic servant, at eight dollars per month. After "doing up" the work, having much leisure, William devoted it to the books in the office. His employer, observing this love of reading, strongly urged him to embark in the study of the law, which he did. He continued as clerk in the office until the winter of 1813, when his employer died. Mr. Angel had then to struggle hard in order to support himself and to complete the term of his clerkship. Having no time allowed for classical studies, he was obliged to serve the full term of seven years, before he was admitted. In August, 1817, he was licensed to practice as an attorney in the supreme court of New York. He commenced business at Burlington, Otsego county, and remained there until 1833. In 1821, he was appointed surrogate of Otsego county, which office he held until the fall of 1824 , 
when he was elected to represent that county in congress. In 182ऽ, he was again elected to congress; and in 1830, in such high estimation did his constituents hold his services, that he was sent a third term. While in congress, he was a member of the committees on Territories and on Indian affairs. He also served on several select committees.

Mr. Angel removed to Angelica, Alleghany county, New York, in 1835, where he still remains. Since his residence in that place, he has had confided to him most of the difficult and intricate business done in the county.

In April, 1846, he was elected to represent Allegany county in the state convention for revising the constitution. He attended the convention from its commencement to the close of its labors, and was a member of the committee upon the subject of local affairs. He devoted much of his time and attention to the articles in the constitution relating to internal improvement, and to the finances of the state.

On the 7th of June, 1847, the humble boy, once hired out as a domestic servant, having three times sat among the magnates of the land, in congress, besides filling other offices of trust and honor, was elected county judge of Allegany county

Never give up! there are chances and changes,

Helping the hopeful, a hundred to one ;

And through the chaos, High Wisdom arranges

Ever success-if you 'll only hope on;

Never give up! for the wisest is boldest,

Knowing that Providence mingles the cup;

And of all maxims, the best, as the oldest,

Is the true watch-word of "Never give up!" 


\section{DIXON H. LEWIS.}

Ample as are the bodily dimensions of Senator Lewis, they are but a true indication of the greatness of his mind. Contrary to the general rule, the preponderance of the outward man does not, in his case, affect the spirit that dwells within. He possesses rare qualities, both of head and heart. Like many others, he has, with indomitable energy, made his way from comparative obscurity, to his present honorable position.

An anecdote is told of him, which is a characteristic one. On his return from Washington to Alabama, some time ago, the vessel in which he had embarked was overtaken by a storm, which so damaged her timbers, that she was soon found to be in, a sinking condition. The safety of the passengers and crew depended on the long boat, to which they had recourse; and she was loaded to the water's edge. Mr. Lewis was the last person on board the sinking ship; and as he was about to leave her, he saw the perilous condition of the boat, which his weight, for he exceeds four hundred pounds, must inevitably swamp, and he positively refused to enter, until she had been to land and deposited her living freight safe on shore. It was a question of one life against many. If he entered the boat, all might be lost, while he alone would sink with the ship, if he were not rescued before she went down; and he generously and heroically resigned himself to what appeared to be inevitable destruction, that he might save his fellow passengers. He was, however, happily saved, and now worthily represents the state of Alabama in the Senate of the United States. 


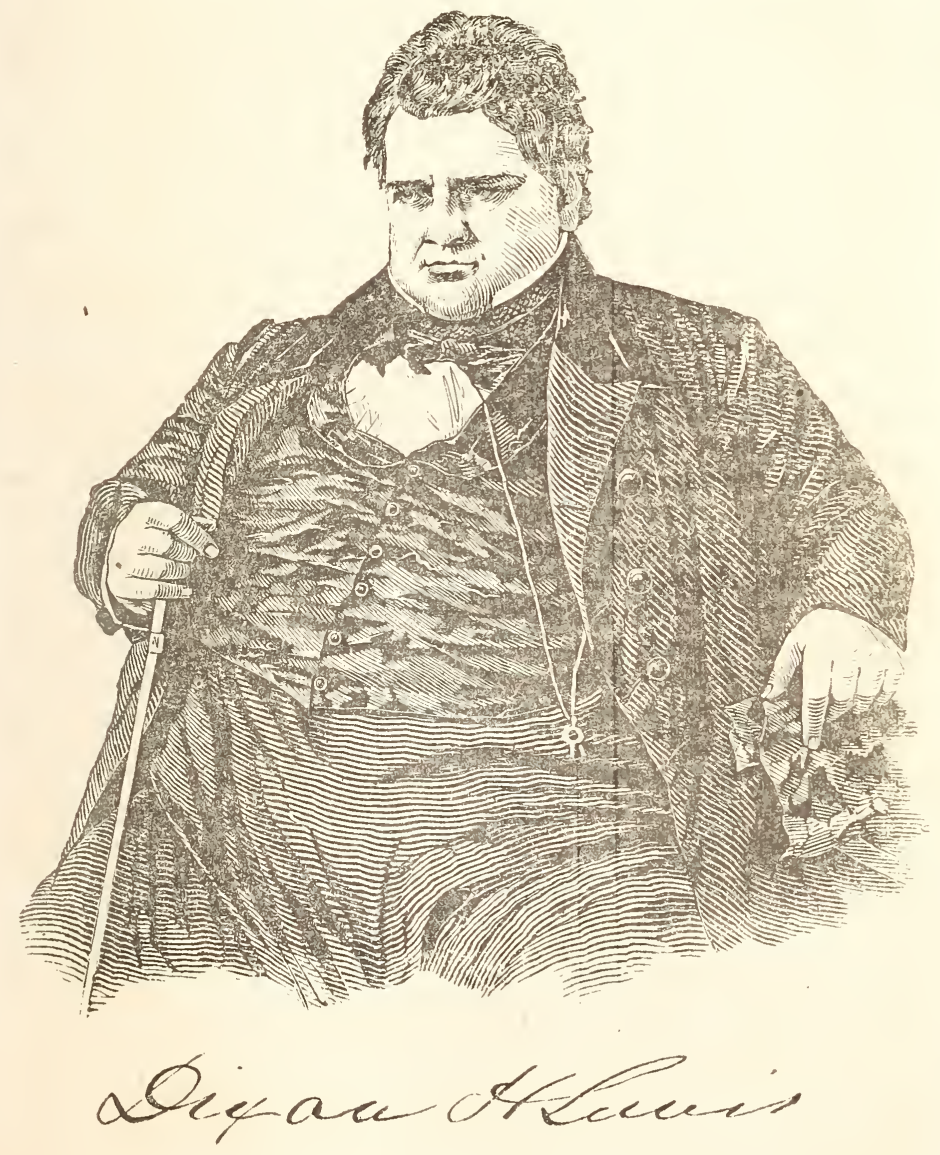





\section{GOVERNEUR KEMBLE.}

The paternal ancestor of Governeur Kemble was of English descent, and emigrated to New York in 1704. His mother's family were French Huguenots. His maternal ancestor, Abraham Governeur, was secretary to Leisler, and, with him and Milbourne, attainted of high treason; which sentence was, however, afterwards annulled. The following passage from Hale's United States, relative to Leisler and Milbourne, may be interesting:

"These men, Leisler and Milbourne, were now in the power of their enraged enemies. They were accused of murder and rebellion; a special court was organized to try them; they were convicted, and received sentence of death. But Slaughter hesitated to sign the warrant for their execution. He knew that they had many warm friends among the people, and that though they had sometimes erred, they had served King William and the protestant cause, with undoubted fidelity and the most ardent zeal. When about to leave New York for Albany, he asked advice of his council on the subject. They being mostly their bitter foes, advised him to sign the warrant. Still he hesitated. But their enemies, thirsting for vengeance, invited him to a feast, and there, when INTOXICATED, they presented to him the warrant, which he signed; and when he recovered his senses, the prisoners had ceased to live. Subsequently, on application to the king, the estates of Leisler and Milbourne (and it is presumed those of others who had been attainted with them) which had been confiscated, were restored to their heirs; their bodies were taken up, and reïnterred with great pomp, in the old Dutch church, and 12 
their descendants were considered honored, rather than disgraced, by the part they acted."

Mr. Kemble, the subject of this sketch, was born in the city of New York, in 1786, and graduated at Columbia college. His father, Peter Kemble, was a merchant, and intended his son for the same profession. In 1809, Governeur went to Europe, where he remained traveling until 1811. Two years after his return, he received an appointment in the staff of General Porter; but the peace with Great Britain, which took place the following winter, prevented his going into the field. In 1814, as assistant navy agent, he accompanied the squadron of Commodore Decatur to Algiers. In 1817, Mr. Kemble established the celebrated West Point foundry, at Cold Spring, for the manufacture of cannon, and which has since been extended to other objects. He continued at the head of it until 1837, when he resigned, on taking his seat in congress, as representative of Westchester and Putnam counties. He was also reëlected to the following congress. While in that body, he was placed upon important committees, and was one of the few who did a great deal of work without making much noise about it. He was not distinguished as an orator, but as a thorough búsiness member, he had but few equals. On the expiration of his second term, in $18+1$, he returned to the foundry, where he still remains. It appears that in this establishment over five hundred men are constantly employed, both in the iron and brass foundry. It has one blast furnace, producing eight hundred and fifty tons of iron annually; three air furnaces, and three cupola furnaces, melting two thousand five hundred tons of iron, and producing articles to the amount of $\$ 280,000$ annually.

In 1846, Mr. Kemble was elected a delegate from Putnam county, in the convention for revising the constitution of the state. 


\section{IRA HARRIS.}

The paternal ancestors of Judge Harris, of the New York supreme court, were among the colonists who, with the celebrated Roger Williams, settled the Providence plantations; where, no longer fearing persecution,

Amidst the storm they sung,

And the stars heard, and the sea!

And the sounding aisles of the dim woods rung,

With the anthems of the free.

The grandfather of the judge, Nicholas Harris, was a physician; and prior to the revolution, he settled in Stephentown, Rensselaer county, New York, where he continued to reside until his death, and where Frederick W. Harris, the father of Ira, was born. He settled upon Clark's patent, in Charleston, Montgomery county, where he married Lucy Hamilton, whose ancestors were from Scotland. Her father and two brothers, then residing at Half Moon, Saratoga county, served in the war of the revolution.

Judge Harris was born at Charleston, New York, on the 31st of May, 1802. When six years of age, his parents removed to the county of Cortland, where he resided with them, laboring upon a farm, and attending school during the winter months, until he was seventeen.

It is a remarkable fact, that most of the eminent men of this country spent their youth as tillers of the soil.

"Rob Roy, upon his native heath, spoke with no less truth than eloquence, when, surrounded by the wild beauty of the highlands, he said: 'My heart would shrink and wither like fern in the frost, 
were I to lose sight of my native hills; nor has the wide world a scene that would console me for the loss of the rocks and cairns around me.' No, it is far from the dust and turmoil of hurried life and fashion, far from mankind checked and constrained by customs inconsistent with nature, far from the glittering lustre and whirl of pleasure, that we must look for patriotism. But where hospitality sequesters herself on the distant hills, where paternal love and conjugal kindness most fondly dwell; where vice, awed by the patriarch's frown, sinks his guilty eye; where the merry dance of village maidens, bespeaks cheerful joy and contentment; there may we hope to find it."

On attaining the age of seventeen, Ira commenced his studies, preparatory to entering college. He continued at the Cortland academy until his twentieth year. He then entered Union college, where he graduated in 1824. After studying law one year in Cortland, he removed to Albany, where he completed his course with the late Chief Justice Spencer, who was justly proud of his student. He commenced the practice of his profession in 1827, and perhaps no man has a greater reputation at the bar.

He has been twice married. His wives were both daughters of Col. Tubbs, of Homer, Cortland county. It was in May, 1845, when the flowers were bursting from the earth, and nature was putting on her smile of joy, that his second companion entered upon her immortal existence.

Of the career of Judge Harris, while in the state senate, it is not within our province to speak. It may, however, be remarked, that in every country, and in our own especially, the more conspicuous a politician is rendered, by his talents, energy, decision of character, or peculiar principles, the more will he become the favorite of some, and the object of dislike to others. No man without enemies, ever possessed much force of character. 



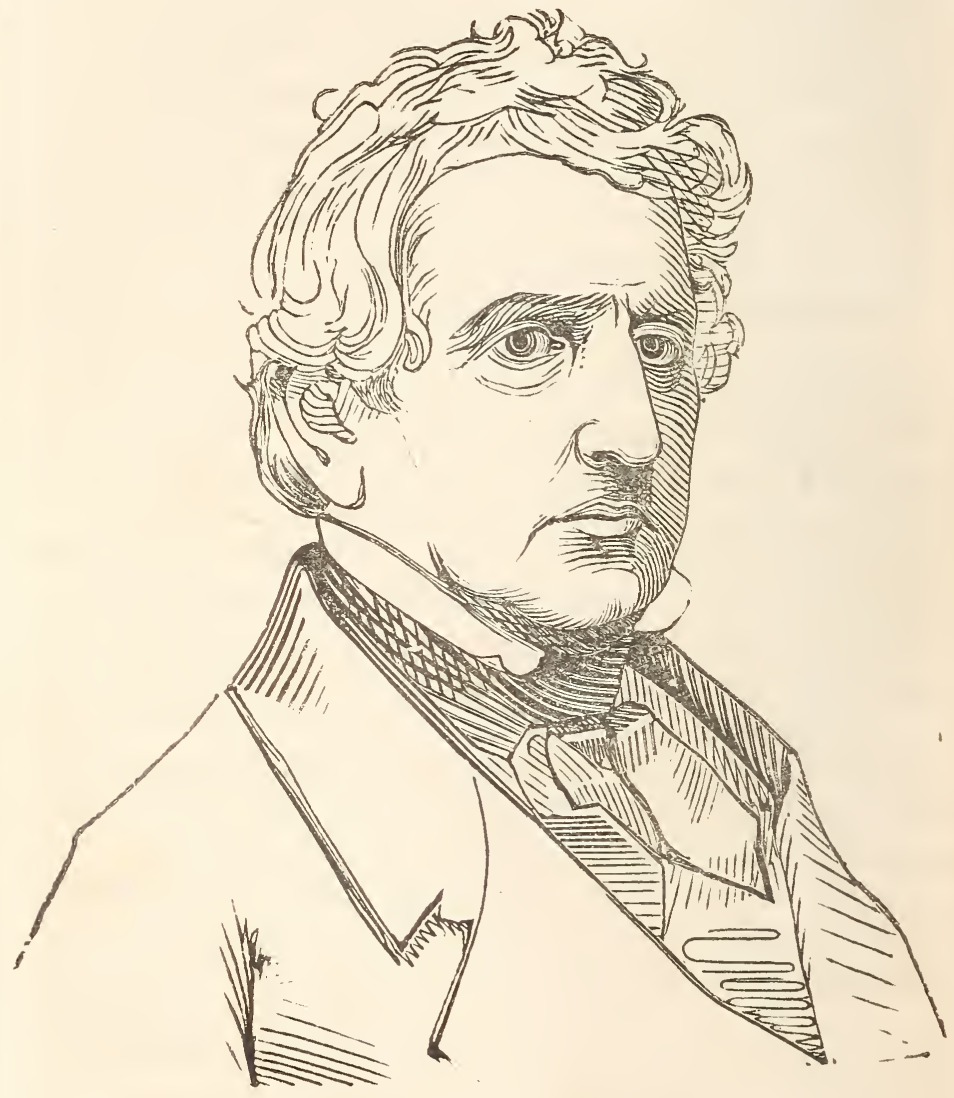

PHILIP HONE. 


\section{PHILIP HONE.}

Who, in New York, has not heard of Philip Hone? His name, for many a year, has been familiar as household words. With none of the ordinary ambition of low minds, he never strove to hide his origin, and the means of his rise. He was born in the city of New York, on the 2.5th of October, 1780. His parents were also natives of that city. Philip, his father, was of German descent, and his mother, whose maiden name was Esther Bourdette, of French extraction. The former was a working mechanic, and at one time followed the business of a house carpenter and joiner; for in those days these two branches of mechanical industry were usually united. He was highly respected as an honest man, and as a good whig-not in the present party sense of the term, but a whig of the revolution. Both parents, whose names are held in the most affectionate remembrance, in 1798 had reached an advanced age. But in the summer of that year, the sentence against the city had gone forth, and the "angel of the pestilence" alighted upon the earth. About the middle of July, the yellow fever commenced raging in almost every street, and by the middle of August the wail and lamentation spread throughout the place. There was a hurrying to and fro, the inhabitants vainly attempting to fly from destruction, followed by carts loaded with furniture. The city, for the most part, was forsaken, and Silence, with weeping eyes, sat in the market place. Among those who left the contagious air of earth for the refreshing breezes of heaven, were Mr. and Mrs. Hone-both dying in September of that year.

At the age of seventeen, the subject of this me- 
moir went into the auction business, with his elder brother, John Hone, and at nineteen became a partner in the concern. In this occupation he was actively and laboriously engaged until 1821, when he went to Europe. On his return, he did not resume his place in the firm. He was one of the original corporators of the Delaware and Hudson canal company, being appointed by the legislature a commissioner to open subscriptions for the stock, and organize the company. He was the first president elected by the stockholders. This office he resigned, on his being elected, in 1826, mayor of New York; having served the two preceding years in the common council, as assistant alderman of the third ward. During the brief space of a year's mayoralty, he was not idle in his attempts to promote the public good; and, judging from the newspapers of that period, his labors were not lightly appreciated by his fellow citizens. Several old residents have informed the writer, that the hospitalities of the city were never more liberally administered than during the mayoralty of Mr. Hone, and that he did honor to the office.

His connection with the aforesaid company was not discontinued; for up to the present time he has acted as one of the managers; with what success, its flourishing condition will show.

On the establishment of the Bank for Savings, in the city of New York, in 1816, an institution which has not only increased the comforts and independence, but raised the moral character of the laboring classes, the legislature appointed Mr. Hone one of the trustees; and in 1841, on the resignation of the late John Pintard, Esq., he was elected president of the bank; the arduous duties of which he has faithfully, although gratuitously, performed. The deep interest taken by him and his associates in this, as guardians and trustees of five millions of 
dollars, literally the savings of the poor, is apparent, and gratefully acknowledged.

During a period of twenty years, Mr. Hone was governor of the New York hospital. This office he resigned, on being appointed president of a board of commissioners to inspect and control the public institutions (of which the hospital is one) which are in part supported by the bounty of the state. He has the honor of being president of the Clinton Hall association, the guardians who exercise a sort of parental influence over the young men constituting the Mercantile Library association. For more than twenty years he has been one of the trustees of Columbia college, and a vestryman of Trinity church for the same period. These, and many other similar employments of a public nature, it may be readily imagined, occupy much of his time, and give him no small amount of labor. He, in fact, appears to be looked upon as public property, inasmuch as his name is frequently put down for such services, without the formality of asking his consent. To stand thus in the estimation of his fellow citizens, is truly an enviable position; but it ought to be remembered, that his gratuitous labors in all these offices, entitle him to a larger share of gratitude than generally falls to the lot of public servants.

The presidency of the American mutual insurance company, he enjoyed during the brief period of its existence, and this afforded him a liberal compensation for his labor. The great fire, however, rendered this company bankrupt, and he is now settling its affairs, as receiver.

Of the political opinions of $\mathrm{Mr}$. Hone, it is unnecessary to speak. It will be sufficient to say, that he has always fearlessly avowed and zealously maintained them. His acts of private benevolence have been numerous. He is not one of those who, when able to relieve, send the poor empty away. 
As will readily be inferred from his length of days, and the amount of labor performed, he did not neglect, at a very early age, to provide himself with that solace, without which the pathway. of this life has but few roses. In October, 1801, he married Miss Catharine Dunscomb, a lady descended, like himself, from highly respected parents, natives of New York. They have three sons and two daughters, of whom they have no reason to be ashamed; and the same good Providence which smiled upon their union, has to this moment blessed them with a happy continuance of its favor. The domestic concerns of a distinguished man, generally excite but little interest; yet to him they are the great and abiding sources of happiness. How many honest, persevering men, make the great mistake of living totally apart from the kindly sympathies of our nature. But when age comes, although the money bags may be full, what a yearning comes over us for those very kindly sympathies. When the strong frame is broken, the eager energies quelled, the fierce passions still within us, and the strong desires sated, with what bitter regret do we admit that there are better things, and more enduring than those we have pursued. When years have brought on the "autumn of the heart," and we feel that it is time to fall away, how priceless become the social ties. In that hour, for what would we exchange the warm embrace of a beloved child, or the soft endearments of a wife, as she bends over the couch of death-when science dares no longer contend with the king of terrors, and skill retires from the unequal task-when she comes like a soft spirit, noiseless, and tearful, and holy, and while kissing away the clammy dews of dissolution, she wrestles with the enemy to the last. 


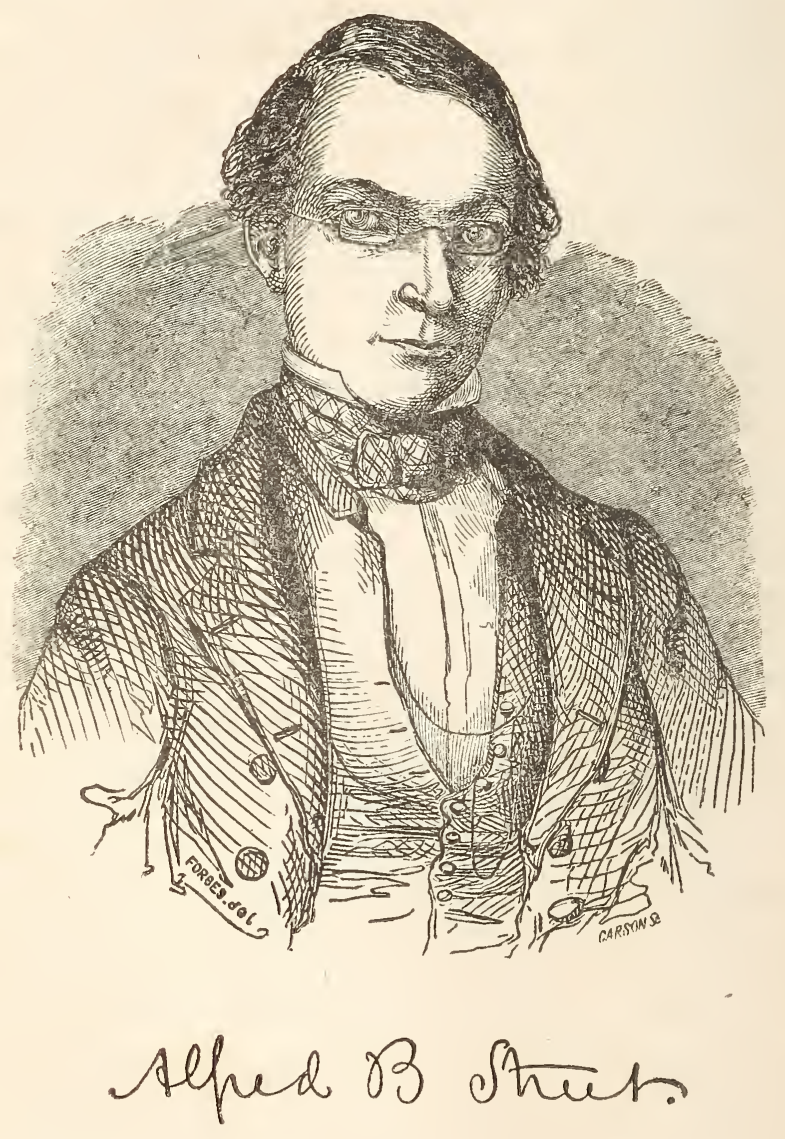




\section{ALFRED B. STREET.}

It was recently remarked of this distinguished poet, that "he dips his pen in sunshine;" and probably no American writer has met with more admirers, both in his own country and in Europe, than Mr. Street.

The beautiful village of Monticello, says a writer in Graham's Magazine, to which his parents had removed, from Poughkeepsie, when he was fourteen years of age, is situated in a picturesque region of wild hills, smiling valleys, and lovely streams. Every thing around bears impress of recent cultivation struggling with the rudeness of primitive nature. Forests are interspersed, waving in broad grandeur-the plow is guided between unsightly stumps-in all directions the log hut shows its crouching roof-the fallow fires glisten in the spring, and the charred trees stand amidst the grain fields of autumn. Early association with such a life, gave the first scope and impulse to our poet's mind. In the midst of these secluded hills he beheld the phenomena of the seasons, as they successively unfolded, with the vivid beauty and extreme alternations of our climate. He saw the trophies of the hunter displayed in the streets of the village, and in his vigils he was often serenaded by the distant howl of the wolves. With a mind of quick and true observation, Mr. Street under such circumstances became a devoted student of nature, particularly in her wild and uncultivated aspects, and found a delightful resource in embodying his impressions in language.

The years thus passed were eminently favorable to the gradual but vigorous development of his perceptions. His pursuit was that of law, which he 
studied in his father's office, at Monticello; but he began to write as early as the age of eleven, although his first poems appeared three years after, in the New York Evening Post, under the signature of Atticus. Among them were, "March," and "A Winter Noon," both exhibiting great promise. From this time, in the intervals of his professional labors, which he still continues successfully to prosecute in Albany, Mr. Street has been an admired and prolific contributor to our best annuals and periodicals, and has delivered two very able poems before the Euglossian society of Geneva, and the Phi Beta Kappa society of Union college. In 1841, the latter college conferred the honorary degree of A. M. upon him. Various compliments of a like nature have been paid him by several of our prominent literary institutions.

Mr. Street is descended, on the father's side, from a good old pilgrim stock, of the state of Connecticut. His ancestor, the Rev. Nicholas Street, emigrated there from England, about two hundred years ago, and was settled as a minister, in New Haven, in 1659. His son, the Rev. Samuel Street, was for forty-two years pastor of the first church of Wallingford. He was esteemed, in the quaint language of the day, "an heavenly man." The descendants of these two, several of whom also followed the sacred profession, and were among the early graduates of Yale, have continued, with the exception of the grandfather of our poet, and his family, to reside in Connecticut. One of them, Augustus Street, Esq., still lives in New Haven.

The subject of the present notice is the son of the late General Randall S. Street, who resided the greater part of his life in the village of Poughkeepsie, Dutchess county, New York. He was the district-attorney of the third district, under the old organization, a major in active service in the late war, and subsequently a representative of the coun- 
ty in congress. Mr. Street's maternal grandfather was Andrew Billings, of Dutchess, a major in the revolutionary army, who was present at the battle of Quebec, where Montgomery so gloriously fell. His maternal grandmother was Miss Cornelia Livingston, daughter of James Livingston, of the widely extended family of that name, in the state of New York. She married first Mr. Van Kleeck, and at his death became the wife of Major Billings. Mr. Street was born in the village of Poughkeepsie, Dutchess county, New York, on the 18th day of December, 1811. He there passed through an academical course of education, and at the age of fourteen, removed with his family to the village of Monticello, Sullivan county, New York, where he continued to live until 18:39, when he removed to Albany, his present residence. In 1841, he married Miss Elizabeth Weed, daughter of the late Smith Weed, of Albany, a retired merchant of wealth and respectability.

The Foreign Quarterly Review, which bears sc. verely upon many other American poets, says of Mr. Street: "He is a descriptive poet, and at the head of his class. His pictures of American scenery are full of gusto and freshness; sometimes too wild and diffuse, but always true and healthful."

Mr. Street, says Tuckerman, is a true Flemish painter, seizing upon objects in all their verisimilitude. As we read him, wild flowers peer up from among brown leaves; the drum of the partridge, the ripple of waters, the flickering of autumn light, the sting of sleety snow, the cry of the panther, the roar of the winds, the melody of birds, and the odor of crushed pine-boughs, are present to our senses. In a foreign land, his poems would transport us at oncè to home. He is no second-hand limner, content to furnish insipid copies, but draws from reality. His pictures have the freshness of originals. They are graphic, detailed, never untrue, and often 
vigorous; he is essentially an American poet. $\mathrm{He}$ is emphatically an observer. In England, we notice that these qualities have been recognized-his "Lost Hunter" was finely illustrated in a recent London periodical-thus affording the best evidence of the picturesque fertility of his muse. Many of his pieces also glow with patriotism. His "Gray Forest Eagle," is a noble lyric, full of spirit. His forest scenes are minutely, and, at the same-time, elaborately true. His Indian legends, and descriptions of the seasons, have a native zest, which we have rarely encountered. Without the classic elegance of Thomson, he excels him in graphic power. There is nothing metaphysical in his turn of mind, or highly artistic in his style; but there is an honest directness and cordial faithfulness about him, that strikes us as remarkably appropriate and manly. Delicacy, sentiment, ideal enthusiasm, are not his by nature; but clear, bold, genial insight and feeling, he possesses to a rare degree-and on these grounds we welcome his poems, and earnestly advise our readers to peruse them attentively, for they worthily depict the phases of nature, as she displays herself in this land, in all her solemn magnificence and serene beauty,

A complete and beautiful edition of Mr. Street's poems, in a large octavo volume of more than three hundred pages, and which has already reached a fifth edition, was published in the autumn of 1846 , by Messrs. Clark \& Austin, of the city of New York. Speaking of this collection, the Westminster (London) Review says :

"It is long since we met a volume of poetry from which we have derived so much unmixed pleasure, as from the collection now before us. In a short and modest preface, the author tells us that his "early life 'was spent in a wild and picturesque region in the southwestern part of New York, his native state. Apart from the busy haunts of mankind, his 
eye was caught by the strongly marked and beautiful scenes by which he was surrounded; and to the first impressions thus made, may be attributed the fact, that his subjects relate so much to Nature, and so little to Man. Instead, therefore, of aiming to depict the human heart, he has endeavored to sketch, (however rudely and imperfectly,) the features of that with which he was most familiar.' And right eloquently does he discourse of Nature, her changeful features and her varied moods-as exhibited in his own 'America, with her rich green forest robe,' and many are the glowing pictures we would gladly transfer to our pages-did our limits permit-in proof of the poet's assertion, that ' $\mathrm{Na}$ ture is Man's best teacher.',

"Such high praise," says the New York Courier and Enquirer, "falls to the lot of but few of our American writers, and we take pride in referring to the fact. Truly, Mr. Street is a painter of nature; original and characteristic. He follows no one; he obeys the promptings of his own genius. In his pages we find no ideas shadowy of othersadumbrations as it were of thoughts not springing from the mind of the poet-a mere effort of a stored memory; all is fresh with hirn-his pictures are drawn from the reality."

It is understood that Mr. Street is preparing for the press a poem entitled, "Frontenac, OR THE Atotarho of the Iroquois: A tale of the forest, of 1696 , in ten cantos, with notes." It cannot fail to meet with a cordial welcome. 


\section{GEN. GEORGE P. MORRIS.}

Gen. Morris was born on the 10th day of October, 1800 , in the city of New York. In 1814, he commenced his career as a writer, by composing several songs. These youthful productions serve to show, that thus early in life he gave indications of possessing that poetic genius and talent, which have since placed him in the first rank, as the song writer of America.

In 1817 , he became an occasional contributor to the New York Gazette; also, to the New York American, while under the editorial charge of Johnstone Verplanck. He continued to write for these and other papers until 1822. His early literary efforts were chiefly anonymous, and their authorship only became known when he began to take his position, by general consent, as a star in the literary hemisphere.

In 1822, Mr. Morris, in conjunction with the late Samuel Woodworth, established the New York Mirror-a paper which speedily acquired, and maintained during its continuance, a high character, and a popularity seldom equaled in the annals of periodical literature in this country. He continued associated with Mr. Woodworth one year, when he became sole editor and proprietor.

In 1825, he wrote the drama of "Brier Cliff;" a play, in five acts, founded upon the events of the American revolution. So popular did this become, that he received for it $\$ 3,500$. It has never been published. Prior, and subsequent, to this period, the pen of Mr. Morris was actively engaged upon various literary and dramatic works. He wrote a number of the "Welcomes to Lafayette," and 
songs and ballads, which were universally popular, besides many prologues and addresses.

Mr. Morris continued the sole editor of the New York Mirror, from the period of his separation from Mr. Woodworth, until 1830, when Theodore S. Fay became assistant editor; and shortly after, N. P. Willis was added to the editorial department. Popular as had been this paper before, this rare combination of talent was destined to, and did, give to it an additional impetus, that increased its already wide-spread popularity, until its circulation reached 12,000 copies. This is not surprising, when it is considered that the editors' department was conducted by such eminent talent, and so peculiarly qualified for a work of that character, and that the paper numbered among its contributors so bright a galaxy of names as those of Paulding, Bryant, Halleck, Sheridan Knowles, Marryatt, Tyrone Power, Leggett, Sprague, Hillhouse, Fanny Kemble, Eliza Cook, Mrs. Embury, Mrs. Thayer, besides many other popular writers of the day. The Mirror gave a new impulse to the literary taste, and elevated the standard by which to estimate that class of periodical literature. Not merely were the talents of Mr. Morris brought into requisition by this publication, but also his skill and taste, in its style. He was the first, in this country, who published engravings on wood and steel, and music, in periodicals; which, in connection with the elegant typographical execution, rendered the Mirror pleasing to the eye, as well as food for the mind. As editor of this paper, he conferred great and lasting benefit upon arts and artists, and youthful writers, by his tact, his liberality, the superiority of his judgment, and the vigor of his abilities. It has been justly said, by one who was contemporaneous with him during this period, that he, by "perseverance and address, disciplined a corps of youthful writers, in the presence of a heavy and constant fire from the 
batteries of foreign criticism" - that he possessed " the rare combination, so valuable in dealing with the numerous aspirants in authorship, with whom his position brought him in contact; of a quick, true eye to discern, in the modesty of some nameless manuscript, the future promise of a power hardly yet conscious of itself, a discretion to guide by some advice, and a generosity to aid with the most important kind of assistance-the firm and open temper which his example tended to inspire into the relation of literary men with one another, throughout the landand more than all, perhaps, by the harmony and union, of such inappreciable value, especially in the beginning of national efforts, between the sister arts of writing, music, painting, and dramatic exhibition, which the singular variety and discursiveness of his intellectual sympathies led him constantly to maintain and vindicate." Many, whose attention will perhaps be arrested by this sketch, will cordially respond to these sentiments.

Mr. Morris, early in life, enroled himself as a private, in the first company of the third regiment of the New York state artillery-a part of that admirable military organization composed of the uniform companies in the city of New York. From the ranks he rose, from grade to grade, until, on the 29th of May, 1837, he was duly commissioned as brigadier-general. This appointment he still holds.

The financial storm which, about the year 1837, and 1838 , rode over the country, prostrating every interest, and wasting all classes, visited even the poet and editor. In consequence of severe losses, sustained chiefly by endorsements for friends, the New York Mirror passed out of the hands of Gen. Morris, and in 1843, its existence ceased.

In 18+2, he wrote an opera for Mr. C. E. Horn, called the "Maid of Saxony," which has not been published. It was performed "with great success, at the Park theatre. The author's benefit was at- 
tended by the talent and beau monde of the city of New York. The press of the city, generally, awarded to this opera high commendation.

From the period when Gen. Morris commenced his career as a writer, his pen has been constantly employed in writing poems, songs, ballads and prose sketches. In 1840, the Appleton's published an edition of his poems, beautifully illustrated by TVeir and Chapman; and in 1842, Paine \& Burgess published his songs and ballads. They were favorably noticed by the press, and these and other editions have large sales. A portion of his prose writings, under the title of "The Little Frenchman and his Water Lots," were published by Lea \& Blanchard, which edition has been followed by others, enlarged by the author.

Gren. Morris has edited a number of works; among them are- "The Atlantic Club Book," published by the Harpers; the "Song Writers of America," by Linen \& Ferrin; "National Melodies," by Hall \& Davis; and, in connection with Mr. Willis, the "Prose and Poetry of Europe and America;" a standard work of great value.

In 1844, in connection with Mr. Willis, he established a beautiful weekly paper, called the New Mirror, which, in consequence of the cover and engravings, was charged by the post office department, a postage equal to the subscription price; and not being able to obtain a just reduction from Mr. Wickliffe, then postmaster-general," the proprietor discontinued it after a year and a half, notwithstanding it had attained a circulation of 10,000 copies. The Evening Mirror was next commenced, and continued for one year, by Messrs. Morris and Willis, when they disposed of it, to the present proprietor.

A few months after withdrawing from the Evening Mirror, Gen. Morris began the publication of the National Press and Home Journal; but as 
many mistook its object, from its name, the first part of the title was discontinued, and in November, 1846, Mr. Willis having again joined his old friend and associate, appeared the first number of the Home Journal-a work which is edited with great taste and spirit, and which has an extended circulation.

Did our limits permit us to make selections from the poetic gems of Gen. Morris, it would be a work of supererogation. Where would be the use of repeating that which has already floated on the breath of music, through the length and breadth, not only of our own land, but of Europe.

Willis, writing to a friend, thus speaks of Morris:

"It may, or may not, be one secret of his popularity, but it is a truth-that Morris's heart is at the level of most other people's, and his poetry flows out by that door. He stands breast high in the common stream of sympathy, and the fine oil of his poetic feeling goes from him upon an element it is its nature to float upon, and which carries it safe to other bosoms, with little need of deep diving or high flying. His sentiments are simple, honest, truthful, and familiar; his language is pure, and eminently musical, and he is prodigally full of the poetry of every-day feeling. These are days when poets try experiments; and while others succeed by taking the world's breath away with flights and plunges, Morris uses his feet, to walk quietly with nature. Ninety-nine people in a hundred, taken as they come in the census, would find more to admire in Morris's songs than in the writings of any other American poet; and that is a parish in the poetical episcopate, well worthy a wise man's nurture and prizing."

Gen. Morris is still in the prime and vigor of life, and it is not unlikely that the public will yet have much to admire from his pen, and which will, without doubt, lift him still higher in the niche of fame 
His residence is chiefly at Under Cliff, his country seat, on the banks of the Hudson, near Cold Springs, surrounded by the most lovely and beautiful scenery in nature, and

"Where Hudson's wave, o'er silvery sands, Winds through the hills afar;"

which cannot fail to keep the muse alive within him, and tune the minstrel to further and still higher efforts.

Although he possesses abilities which eminently qualify him for public station, his literary taste and habits have, in spite of the strenuous solicitations of his friends, led him to prefer the retirement of private life. This, however, does not prevent his เaking an active interest in all questions of public good, and the city of New York is greatly indebted to his vigorous aid for many of her most beautiful and permanent improvements.

We cannot close this sketch without adverting to the following incident, which recently occurred in the British house of commons:

Mr. Cagley, a member from Yorkshire, concluded a long speech in favor of protection, by quoting nearly the whole of "Woodman, spare that tree!" (which was received with great applause,) the "tree," according to Mr. Cagley, being the "constitution," and Sir Robert Peel the "woodman," about to cut it down.

What poet could desire a more gratifying compliment? 


\section{WILLIAM W. CAMPBELL,}

Was born in Cherry Valley, Otsego county, New York, on the 10th day of October, 1806. His ancestors came to this country, from the North of Ireland, where some branch of the family had removed from Argyleshire, Scotland, during the persecutions of the 17th century, in the times when the Stuarts brought to the block, in Edinburgh, two of the clan, a marquis and an earl of Argyle, for their attachment to the reformed religion, and opposition to the cruel treatment of their countrymen by the profligate associates of Charles II., and James II. The Campbells of Scotland, from whom the subject of this notice is descended, trace their genealogy back, in an unbroken line, for the period of eight hundred years, and have been, at different times, connected, by marriage, with the kings of Scotland.

Mr. Campbell, during a tour recently made in Europe, visited Scotland. He was there at the reception of the queen, which brought together all the Scottish clans, among them the one from which he descends, and received a cordial welcome. At a dinner given by the Celtic society, composed of all the various tartans of the Scottish clans, upon the beautiful lawn near the castle of the duke of Argyle, to which he was an invited guest, the following interesting incident occurred, illustrative of the Scottish character:

The president of the society, in allusion to him, stated there was one among them who had long been a wanderer from the Highland flock; indeed, one who now sets his foot upon the soil for the first time-whose ancestors, nearly a century and a half ago, were driven out of Scotland by persecution, for 


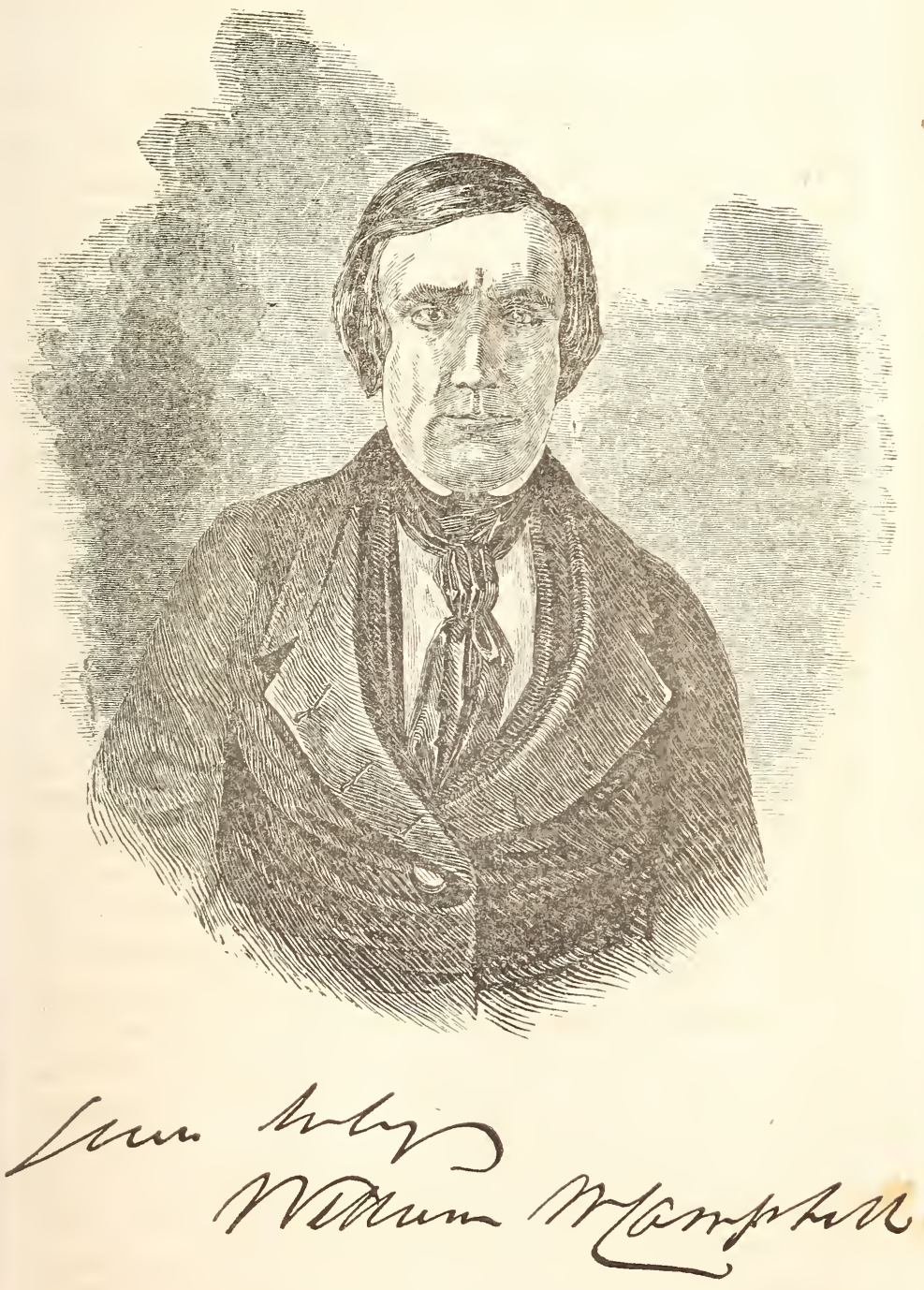



conscience sake, and who is the first of his immediate race who has returned to his ancestral landand, belonging by blood, as he does, to a very old branch of the powerful clan of Argyle, he trusted the society would adopt the motion which he would make, which was, that this gentleman should be elected an honorary member of the society. The proposition was adopted by acclamation, and his health drank with Highland honors: each chieftain standing, with his left foot upon his chair, and the right resting on the edge of the table, carried his glass slowly around his head, with his right hand, repeating after the president, in Gælic, neish, neish, sheel orra neish, (now, now, here is to him now,) after which the old piper of the marquis of Breadalbane, who had been 'an attentive listener, struck up the stirring tune of the clans, sung at the gathering in 1745, "Oh, you are long in coming, but you are welcome," \&c.

The Campbells were among the early pioneers in the settlement of the state of New York. James Campbell, the great-grandfather of the subject of this sketch, removed, in 1741, to Cherry Valley, from Londonderry, New Hampshire, where he, with several others, had, several years anterior, first settled, on arriving from the north of Ireland. The spot where Cherry Valley is now located, was then an entire wilderness. With the exception of a few German families, scattered along the borders of the Mohawk, the whole country, known as the great west, was a virgin forest; indeed, the whole coun1ry west of Cherry Valley, reaching on to the Pacific ocean, with the exception of a few scattered settlers, who had intermarried with the red men, and introduced some slight features of civilization, was an almost unbroken wilderness.

Col. Samuel Campbell, well known as one of the patriots of the revolution, was a son of James Campbell, and in his third year when he came 
with his father to reside at this place. During the French war, he was an active and efficient citizen, and was of essential service to the then government, in assisting in the transportation of supplies to the western ports. At the commencement of the war of the revolution, he espoused, with great ardor, the cause of the colonies, was an officer in the army of the United States, and rendered his country important aid. A garrison was erected upon his farm, and for some time kept there. The exposed situation of the frontier settlements, led to frequent attacks by the combined tory and Indian forces, who ravaged the borders, and committed, whenever opportunity offered, the most barbarous atrocities; in fact, in the language of the late De Witt Clinton: "Their deeds are inscribed, with the scalping knife and tomahawk, in characters of blood, on the fields of Wyoming and Cherry Talley, and on the banks of the Mohawk." In many of these skirmishes and actions, Col. Campbell bore a conspicuous and honorable part. He especially distinguished himself in the battle of Oriskany, on the 6th of August, 1777, under Gen. Herkimer; and when the brave Col. Cox fell, in that sanguinary contest, he took command of the regiment, and brought off the remnant of it, at the close of that disastrous engagement. At the massacre in, and conflagration of, Cherry Valley, in November, 1778, in consequence of being an active partizan, he suffered severely. His property was destroyed, and his wife and four children were taken prisoners by the Indians. Mrs. Campbell was marched, at that inclement season of the year, on foot, to what is now known as Tioga point, in Pennsylvania, and thence by the head of Seneca lake, to the Indian castle, about two miles from where the village of Geneva now stands. Here she spent the winter, in an Indian village, but was treated with comparative kindness by her captors-but still suffered severely for the 
want of clothing. Towards spring, the British offcers in garrison at Fort Niagara, learning that there was a lady who was a prisoner at the castle, near the ontlet of Seneca lake, sent a messenger with female clothing, and provision, to her relief. In the spring she was taken to Fort Niagara, and ransomed from the Indians, and from thence sent to Montreal.

Governor Clinton and General Schuyler made special efforts for her liberation, and at length prevailed upon the British authorities, after she had been in captivity two years, to exchange her for a Mrs. Butler and her children, who had fallen into the hands of the Americans. She returned to Cherry Valley at the close of the war, and had the pleasure of entertaining, under her own roof, Gen. Washington, Gov. Clinton, and other distinguished men. She is said to have possessed great fortitude, decision, clearness of perception, and a native dignity that never failed to elicit commendation from those brought in contact with her. She was exemplary as a wife, a mother, and a Christian, and discharged her duties in these several relations in a manner worthy of imitation.

After the close of the war, Col. Campbell was elected to the state legislature. He died in September, 1824, at the advanced age of eighty-six years. His brother, Robert Campbell, was killed while fighting bravely for his country, in the battle of Oriskany.

William Campbell, the eldest son of Col. Campbell, who was taken captive with his mother, was a highly useful and distinguished citizen of this state. He succeeded the late Simeon De Witt, as surveyor-general of the state of New York, was several times elected a member of the legislature, and held other important public stations. He died at his residence, in Cherry Valley, a few years since, aged 77 years. 
The father of the subject of this biography is James S, a son of Col. Campbell. He is still living on the homestead of his father. He married a daughter of Col. Elderkin, of Windham, Connecticut.

William W. Campbell was early placed at the academy in Cherry Valley, where he studied, preparatory to entering upon is collegiate course. He entered Union college, at Schenectady, in his nineteenth year, and graduated at twenty-one. Upon leaving college, he removed to the city of New York, and entered the law office of Chancellor Kent, to qualify himself for the bar.

In 1831 and 1832, he was a member of the House of Debate, and the New York Young Men's Society, established for literary objects, and of the last named society he was corresponding secretary. At this time he began to give indication of talents of a high order, and which have since given to him a prominent position, as a writer of no ordinary merit. In the fall of 1830 , a society was formed in the village of Cherry Valley, for literary purposes generally, but especially for collecting facts illustrative of the natural and civil history of that section of the country. Having been requested to collect and embody the events connected with it, he conceived a design of writing a history of that town. But, upon examination, finding its revolutionary history so intimately connected with the whole valley of the Mohawk, he abandoned his limited intention, and began a history of Tryon county - a county which had been taken from that of Albany, in 1772, and named after William Tryon, then Governor of the province. In 1784, its name was changed to Montgomery. When formed, it comprised all that part of the state of New York lying west of a line running north and south nearly through the centre line of the present county of Schoharie. It therefore constituted a section of the 
state which had been the scene of some of the most thrilling and important events which marked the revolutionary drama, and rich in the historical associations of that erentful period. In the latter part of 1831, Mr. Campbell completed this work, and the same year it was published by the Harpers, under the title of "The Annals of Tryon county, or the Border Warfare." This book, indicating great research, and containing. much valuable historical matter, and many interesting incidents, woven together by the pen of the historian, in a style, earnest, truthful and eloquent, at once established his reputation as a scholar and a writer of great merit.

Notwithstanding Mr. Campbell had to contend with the eminent talent at the bar of New York, where he commenced his career, and against a competition startling to the young tyro, he soon acquired a good practice, and a standing as a lawyer of high legal abilities, and of sound judgment; and more than all, in importance to the advocate, a reputation as a SAFE ADVISER.

In August, 1ऽ33, he married a daughter of Col. Samuel Starkweather, a lady distinguished for her personal attraction, accomplished mind, and agreeable manners.

In February, 1839, Mr. Campbell delivered a lecture before the Historical society, on the life and military services of Gen. James Clinton-a subject with which his previous historical investigations had made him entirely familiar. On the 4 th of July, 1840, he pronounced the address, at the centennial celebration of the citizens of Cherry Talley. This address contained many valuable historical facts connected with the early settlement of that town. It was in every respect an able production, and greatly added to the reputation which he already enjoyed as a literary man and a public speak. er. It was delivered to the largest audience that 
probably ever assembled at that place. The lecture and address have both been published.

Enjoying the personal friendship of Gov. Seward, who had graduated about the same time, at Union college, the latter, while at the head of the state government, conferred upon Mr. Campbell the office of master in chancery, for the city of New York; and subsequently, upon a vacancy occuring upon the bench of the court of general sessions of that city, tendered to him that place, which honor, although highly appreciated, was declined, from a preference he entertained for the appointment he then held. In 1942, he was appointed one of the commissioners in bankruptcy, for the southern district of New York. The office of master he held until the democratic party came into power again, in 1844, and that of commissioner until the repeal of the bankrupt law.

In $18+3$, the native American party was organized in the city of New York; and in 1844, Mr. Campbell, although a decided whig, having indicated a concurrence in the leading measures of the new party, was brought forward by them as a candidate for congress, in the sixth congressional district of the state. Ely Moore was nominated by the democrats, and Hamilton Fish by the whigs. But, Mr. Campbell being well known as an ardent supporter of Henry Clay, the whigs did not press their candidate. Under these circumstances, by the united rote of the whigs and natives, Mr. Campbell was elected a representative in the 29th congress. Soon after taking his seat, he called the attention of that body to the necessity of a reform in our consular system, and as a member of the select committee on that subject, he made an able report. Upon all great questions affecting the interests of the city of New York, he was an active and able coadjutor. Upon the Oregon question, the Mexican war, and other subjects then in agitation, he took a 
prominent part, uniformly, voting with the whig party, in their leading measures, although he did not lose sight of the interests of the party who nominated him.

In 1846, Mr. Campbell was again nominated by his party, but on this occasion the whigs, although well satisfied with his course in congress, resolved, at all hazards, upon breaking down the native American organization. Hence Mr. Campbell was opposed by both whig and democratic competitors, and his defeat became inevitable.

In July, 1845, Mr. Campbell, as the appointed orator, delivered the annual address before the Phi Beta Kappa society of Union college. It was highly eulogized by the press.

As a public speaker, Mr. Campbell never fails to interest. His language is chaste and eloquent, and he invariably impresses his audience with a conviction of his sincerity. Upon the numerous able addresses which he has on various occasions delivered, by request, before literary and other societies, our limits will not permit us to dwell. Still in the prime of life, he enjoys the esteem of all who know him, and none can speak of him, but as a firm and true friend. 


\section{AMASA J. PARKER.}

One day, as Sir William Jones and Thomas Day were removing some books, in the chambers of the former, a large spider dropped upon the floor, upon which Sir William, with some warmth, said: "Kill that spider, Day-kill that spider!" "No," said Mr. Day, with that coolness for which he was so conspicuous, "I will not kill that spider, Jones; I do not know that I have a right to kill that spider! Suppose when you are going in a coach to Westrninster hall, a superior being, who, perhaps, may have as much power over you, as you have over this insect, should say to his companion: 'kill that lawyer; kill that lawyer!' How should you like that, Jones? And I am sure, to most people, a lawyer is more repulsive than a spider."

How justly soever Mr. Day's remark may apply to lawyers in general, Judge Parker is a remarkable exception; for his manners, both on the bench and in the social circle, are ever such as to remind us of the passage of holy writ, where it is said, "justice and mercy met and kissed each other."

This gentleman, who holds so conspicuous a place among the distinguished men of the empire state, was born at Sharon in the parish of Ellsworth, Litchfield county, Connecticut, on the second of June, 1807. It has been remarked, that there is no neighborhood in the United States, of the same limits and population, which has been the birthplace, or the home, of so many eminent men, as the county of Litchfield. It is a region of hard hills and rocky farms, contiguous to no commercial cities, and crossed by no important lines of travelbut its homesteads, so quiet and retired, have been favorite haunts of the genii. Here the bracing air 


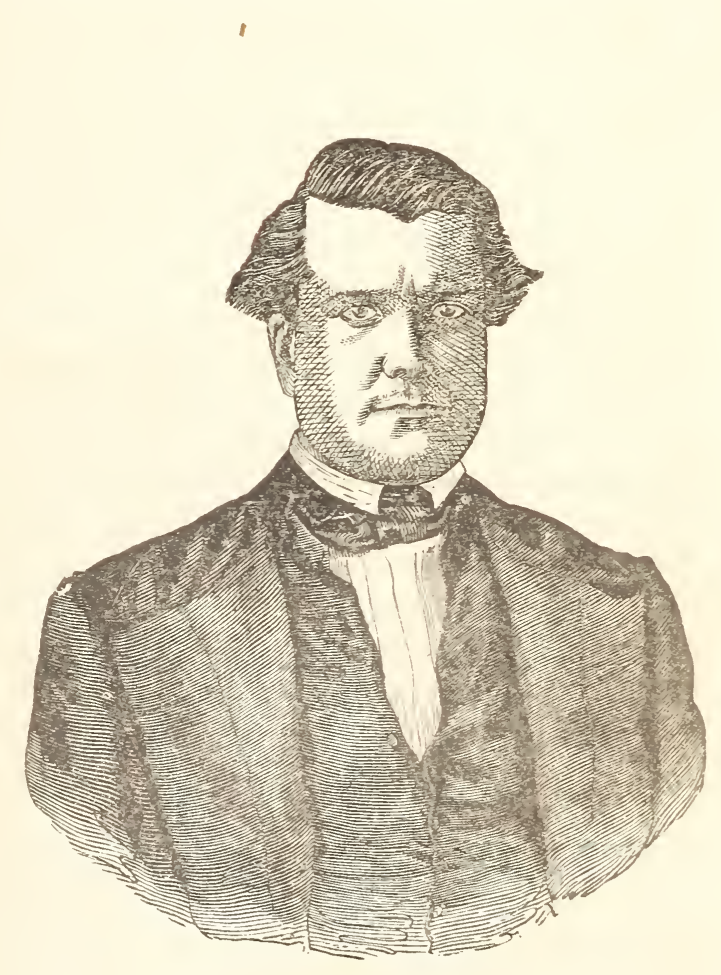

A. J. PARKER 。 

of the highlands, and the habits of industry and self-dependence, formed from childhood, have given strong lungs and vigorous frames, expanded souls, and spirits full of energy, to a hundred men, where the influences of city life will scarcely endow with the same gifts a single one.

The father of Judge Parker, was the Rev. Daniel Parker, who was the pastor of the congregational church of Ellsworth parish. His ancestors were of the good old puritan stock of New England, and had resided in the western part of Connecticut for several generations. His paternal and maternal grandfathers, Amasa Parker and Thomas Ferin, both served in the revolutionary war, and were respected for their integrity and moral virtues. The latter was for twenty years a representative in the state legislature, and a magistrate. They lived and died at Watertown, in that state.

The Rev. Daniel Parker was a graduate of Yale college. He married Miss Anna Fenn, daughter of Thomas Fenn, Esq., and was for almost twenty years a settled minister at Ellsworth. During that period he established, and had charge of, an academy at that place, which acquired a high reputation, and in which many young men, since distinguished in many parts of the Union, were educated.

In 1816, the reverend gentleman removed to Greenville, Greene county, New York, and took charge of the academy at that place. It was at that place, that the subject of this memoir, then only nine years of age, commenced the study of the Latin language. After remaining there two years, he spent a like period at the Hudson academy, and subsequently three years in the city of New York.

Judge Parker was the eldest son, and, ever eager to learn, pains were taken with his education; his father devoting the most constant attention to it, and securing him the instruction of the most careful instructors and professors in the country. 
As all those acquainted with him may readily infer, no man was ever more completely and critically instructed, in a course of classical education, than himself. 'To a thorough knowledge of the dead languages, was added.an acquaintance with modern tongues, and belles-lettres, as well as the more severe studies of mathematics.

At the age of sixteen, he had completed the usual course of collegiate study, although not within the walls of a college, being precocious in intellect, as well as in stature.

In May, 1823, as its principal, he took charge of the Hudson academy, an incorporated institution, subject to the visitation of the regents. During the four years which he remained at its head, the academy enjoyed a high reputation, and was in a most flourishing condition. His age was not then mature, and his pupils, scattered over the state, were afterwards surprised to learn, that their preceptor was younger than many of themselves. During this time, the argument was used by the academy at Kinderhook, a rival institution, that the principal of the Hudson academy was not a graduate of a college. To obviate any such objection, Mr. Parker availed himself of the opportunity afforded by a short vacation, to present himself at Union college, in order to take an examination for the entire course, and to graduate with the class. This he did, and took his degree of bachelor of arts, in July, 1825.

During the latter part of his term at the Hudson academy, he was entered as a student at law, in the office of that sound jurist, John W. Edmonds, then residing at Hudson, and since circuit judge of the first circuit, and justice of the supreme court.

At the age of twenty, in the spring of 1827, having resigned his charge, Mr. Parker retired to Delhi, Delaware county, for the purpose of pursuing his legal studies, in the office of his uncle, Col. Amasa 
Parker, a practising lawyer of eminence at that place. He continued there until his admission to the bar, at the October term, in 1828. He then formed a law partnership with his uncle, which lasted over fifteen years, during which period they were engaged in a most extensive practice.

Immediately on his admission, he entered the higher courts, as an advocate; and, taking upon himself that branch of the business, he was for many years much abroad, at the neighboring circuits, and at the terms of the common law and equity courts.

Delaware county having for forty years been strongly democratic in its politics, Mr. Parker was early in life engaged in the great political struggles of the day. In the fall of 1833, at the age of twenty-six, he was elected to the state legislature, where he served on the committee of ways and means, and in other important positions, during the winter of 1834 . In 1835, he was elected by the legislature a regent of the New York state university-a rare honor for so young a man-this distinction never having been before conferred upon one of his age.

At the age of twenty-nine, he was elected a member of the twenty-fifth congress, to represent the congressional district composed of the counties of Delaware and Broome. It is here worthy of remark, that at both elections he ran without opposition, the opposite party deeming it useless to bring a whig candidate into the field against him.

While in congress, he served upon several important committees, and his speeches, most of which the writer heard, were upon the public lands, the Mississippi election question, the Cilley duel, and other great subjects of the day, all of which may be found in the Congressional Globe. His speech on the knotty points involved in the Mississippi election case, was pronounced, by men of both 
parties, to be one of the best logical speeches they had heard for many years. He untwisted the sophisms which had been mixed up with the question at issue, and presented it in so clear a light, that conscientious members, who had in vain been trying to comprehend the point in dispute, could now vote understandingly upon it.

In the fall of 1839 , he was a candidate for the office of state senator, in the third senatorial district. The canvass was a very excited one, owing to the fact that a United States senator was to be elected by the next legislature, in the place of $\mathrm{Mr}$. Tallmadge. Very great exertions were made, and about fifty thousand votes were polled. The result was, the election of the whig candidate, the late Gen. Root, by a very small majority.

This defeat of Mr. Parker was, without doubt, a fortunate event for his professional reputation, as it enabled him to prosecute the practice of his profession with renewed energy and success, until he was appointed to the bench, on the 6th of March, 1844.

On accepting, with hesitation, the appointment of circuit judge, he repaired immediately to the city of Albany, where he continued to reside during his term of office. The duties of the office were very laborious, and required the most constant application. As circuit judge in the common law courts, and as vice chancellor in the court of equity, the whole of his time was occupied, and heavy responsibilities devolved upon him.

In addition to the ordinary business of his district, the anti-rent difficulties added much to his labors. He commenced his civil calenders with questions of title, and at the oyer and terminer, the most painful duties were imposed upon him, in punishing violations of the public peace. His labors at the Delaware circuit, in 1845, will not soon be forgotten. He found in jail about a hundred 
and ten persons, under indictment. At the end of three weeks, the jail was cleared, every case having been disposed of, by conviction or otherwise. Two were sentenced to death, for the murder of Sheriff Steele, and about fifteen to confinement, for various periods, in the state prison: for the lighter offences, fines were in several cases imposed. The course pursued by Judge Parker, met with general approbation. After the adjournment of the court, the military force was discharged, peace was restored, and in no instance has resistance to process since occurred in that county.

No criminal trials in the state were ever surrounded with such difficulties, or more imperiously required the exercise of firmness, caution, energy, and promptness. The following summer the degree of LL. D. was conferred upon Judge Parker by Greneva college.

On the 27th of August, 1834, Judge Parker was united in marriage with Miss Harriet L. Roberts, of Portsmouth, New Hampshire, by whom he has had six children. The writer has heard her kindness to the suffering poor, spoken of with heart-felt gratitude.

The judge received from his father no patrimony, except his classical education. The means of acquiring his professional education, he obtained by his own industry, as a teacher. He has always applied himself with great industry to his profession, and has ever relied on his own energy for success. By these exertions he has been able to surmount every obstacle, and to attain his present elevated position. His term of office as circuit judge, terminated with the constitution, and at the first periodical election held under the new constitution, the little boy who commenced learning Latin at nine years of age, was elected "justice of the supreme court of the state of New York."

His election is considered as a most triumphant 16 
vindication of the policy of committing the choice of judicial officers to the people. He was elected in whe third judicial district, although in the seven counties which compose it, an adverse influence had been at work. It was thought that great prejudice existed against him, on account of the duties his office compelled him to perform at the Delaware trials-yet his majority over the opposing candidate was nearly six thousand, embracing many of all parties, who came forward to cast their influence in favor of a candidate who had kindly, but firmly, enforced the execution of the law.

We will conclúde this sketch in the words of a distinguished senator, who, in a recent speech, alluding to Judge Parker, said: "every one will admit that he is one of the ablest judges this state has produced."

\section{THEODORIC ROMEYN BECK,}

Was born at Schenectady, New York, on the 11th of August, 1791. His parents were highly respectable. According to the National Picture Gallery, his grandfather was the Rev. Theodoric Romeyn, D. D., one of the professors of theology in the reformed Dutch church, and one of its most distinguished ornaments. The rudiments of Dr. Beck's education were received at the grammar school in his native place, and in 1803 he entered Union college, an institution which had been established a few years previously, principally through the active exertions of his grandfather. He graduated in 1807, and commenced the study of medicine under the late Drs. McClelland \& Low, of Albany. His medical education was afterwards completed under the care of the celebrated Dr. Hosack, of New York, 
in which place he attended the lectures of the College of Physicians and Surgeons, and in 1811, obtained from that jnstitution the degree of doctor of medicine. On that occasion, he wrote and published an inaugural dissertation on insanity. He immediately afterwards commenced the practice of his profession in the city of Albany. In 1815, he was appointed professor of the institutes of medicine, and lecturer on medical jurisprudence, in the College of Physicians and Surgeons, of the western district of the state of New York, and is now professor of materia medica in the Albany Medical college.

In 1817, owing to a growing fondness for literary pursuits, he abandoned the practical exercise of his profession, and accepted the situation of principal of the Albany academy. Under his superintendence, this academy attained a high and deserved rank among the literary institutions of our country.

It is as an author, however, that Prof. Beck is mainly distinguished. In 1813, he delivered the annual address before the Society of Arts, of Albany, on the mineralogical resources of the state. This, the earliest systematic account of the mineral wealth of our country, received high commendation. In 1823, he published, in two octavo volumes, Elements of Medical Jurisprudence, which at the time attracted great attention, and has since continued a standard work on the subject of which it treats. In foreign countries, the merit of this work has been duly appreciated, and magnanimously acknowledged; and in the various medical colleges of Great Britain it has, for years, been recommended to students, by professors. In 1828, it was translated into German, by Weimar, and has been favorably received in the various parts of the continent of Europe.

Prof. Beck is one of the founders and active supporters of the Albany institute, a scientific and lite- 
rary association. Of his personal qualities, it is sufficient to say, that he is universally respected and esteemed. Unpretending in his manners, and studious in his habits, the voice of praise has not rendered him arrogant and indolent, and the science of his country has yet much to hope from his labors and learning.

\section{FREDERICK A. TALLMADGE.}

It has been truly observed, that there can hardly be a more sublime spectacle for our admiration, than that of a young man, who, urged on by the impulse of struggling intellect, starts boldly from the ranks of obscurity, determined to battle his way through every obstacle to honor and renown.

Of such is the talented subject of this sketch, who by his own well directed energy, became an eminent lawyer of the city of New York, where, in addition to other offices, he was appointed recorder of the court of general sessions. He is now a representative of the state of New York in the thirtieth congress, in which body, with his rare business talents, he can not fail to render important service to his country. Unlike many others, he does not weaken his arguments by a multitude of words, but invariably comes to the point at once. With such men in the national legislature, the business of the country would never suffer from delay. Quick, ready and ardent in the pursuit of any thing on which his mind is set, Mr. Tallmadge has made rapid and solid advancement in almost every branch of useful knowledge. 



\section{JOHN W. FRANCIS.}

This celebrated gentleman, says Poe, in his capocity of physician and medical lecturer, is far too well known to need comment. He was the pupil, friend, and partner of Hosack-the pupil of Abernethy-connected in some measure with every thing that has been well said and done, medically, in America. As a medical essayist, he has always commanded the highest respect and veneration. Among the points he has made, at various times, may be mentioned his Anatomy of Drunkenness; his Views of the Asiatic Cholera; his Analysis of the Avon Waters of the state; his establishment of the comparative immunity of the constitution from a second attack of yellow fever; and his pathological propositions on the changes wrought in the system by specific poisons through their assimilation-propositions remarkably sustained and enforced by recent discoveries of Liebig.

In unprofessional letters, Dr. Francis has also accomplished much, although necessarily in a discursive manner. His Biography of Chancellor Livingston, his Horticultural Discourse, his Discourse at the opening of the new hall of the New York Lyceum of Natural History, are (each in its way) models of fine writing, just sufficiently toned down by an indomitable common sense.

Dr. Francis is one of the old spirits of the New York Historical society. His philanthropy, his active, untiring beneficence, will forever render his name a household word among the truly Christian of heart. His professional services and his purse are always at the command of the needy; few of our wealthiest men have ever contributed to the 
relief of distress so bountifully-none certainly with greater readiness or warmer sympathy.

His person and manner are richly peculiar. He is short and stout, probably five feet five in height, limbs of great muscularity and strength, the whole frame indicating prodigious vitality and energythe latter is, in fact, the leading trait in his character. His head is large, massive-the features in keeping; complexion dark florid; eyes piercingly bright; mouth exceedingly mobile and expressive; hair gray, and worn in mattcd locks about the neck and shoulders-eyebrows to correspond, jagged and ponderous. His age is about fifty-eight. His general appearance is such as to arrest attention. He is married.

\section{BISHOP HUGHES.}

The Right Reverend John Hughes, one of the catholic Bishops, of New York, or, as his title says, bishop of Bascepolis, is a proper sample of republicanism in religion-of the moral worth of man over the fortuitous circumstances of birth. Born in an humble rank of life, by his own talents he has raised himself to the high position he now occupies in the catholic church.

Bishop Hughes is a native of the south of Ireland, and of humble origin. He came to this country in early life. He was educated at the catholic college of Emmetsburg, in Maryland, where, it is said, he was for some time employed as a gardener in the grounds of the college. If so, it redounds to his honor, as it shows that perseverance and talent will surmount the greatest obstacles. He completed his collegiate studies with the highest honors. 


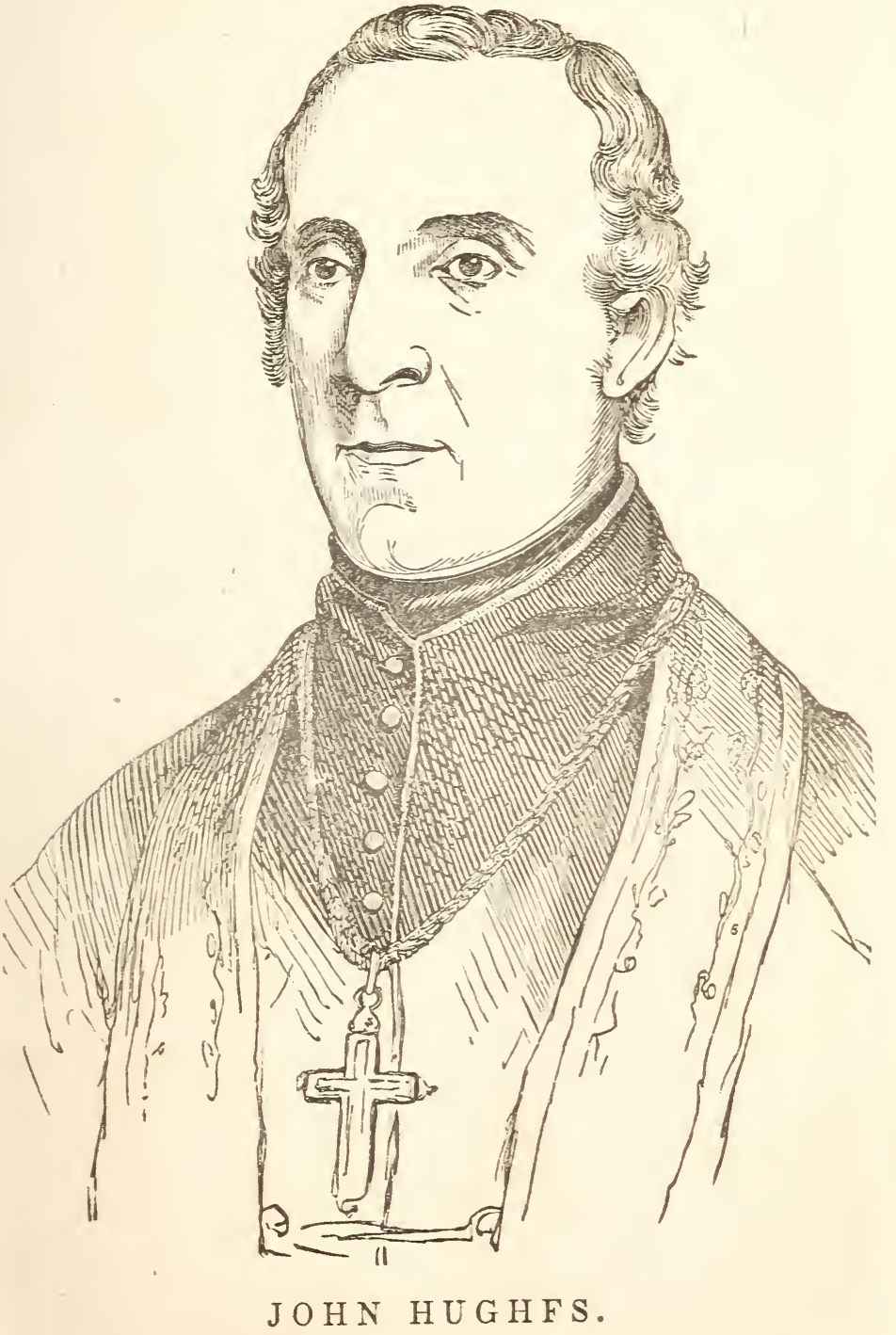



Being ordained priest, he was stationed at Philadelphia. Eleven years afterward, he was sent to be coadjutor to Bishop Dubois, of New York, whose successor he is. It is generally admitted, that Bishop Hughes is the most talented prelate, of his persuasion, on the American continent. $\mathrm{He}$ is about forty-five years of age.

In a letter addressed to James Harper, the late mayor of New York, in 184t, Bishop Hughes says:

"It is twenty-seven years since I came to this country. I became a citizen, as soon as my majority of age, and other circumstances permitted. My early ancestors were from Wales; and very probably shared, with Strongbow and his companions, in the plunder which rewarded the first successful invaders of lovely but unfortunate Ireland. Of course, from the time of their conversion from paganism, they were catholics. You, sir, who must be acquainted with the melancholy annals of religious intolerance in Ireland, may remember, that when a traitor to his country, and, for what I know, to his creed also, wished to make his peace to the Irish government of Queen Elizabeth, MacMahon, prince of Monaghan, the traitor's work, which he volunteered to accomplish, was "to root out the whole sept of the Hugheses." He did not, however, succeed in destroying them, although he "rooted them out"proving, as a moral for future times, that persecution cannot always accomplish what it proposes. In the year 1817, a descendant of the sept of the Hugheses came to the United States of America. He was the son of a farmer of moderate but comfortable means. He landed on these shores friendless, and with but a few guineas in his purse. He never received of the charity of any man without repaying; he never had more than a few dollars at a time; he never had a patron-in the church or out of it; and it is he who has the honor to address you now, as catholic bishop of New York." 


\section{NATHAN CLIFFORD,}

The present attorney-general of the United States, is another of those who have achieved an honorable distinction, by the unassisted power of their own efforts. He belongs to a respectable family, which emigrated from England at an early period, and settled in the southern part of New Hampshire. "His grandfather, Nathan Clifford, removed subsequently, to the town of Rumney, in that state, where the subject of this sketch resided until his death, in the year 1819. His son, Nathan Clifford, was born on the 18th of August, 1803. He received the rudiments of his education at a public school, which he attended only a few months of the year, in the neighborhood of his paternal home. At the age of fourteen, he became a pupil of the Haverhill academy, which he left in 1820 , to profit by the superior advantages of the literary institution at New Hampton. At the latter place, he was enabled to prosecute his studies but little more than a year, at the expiration of which time he entered, as a law student, the office of the distinguished Josiah Quincy. During this period, of four years, from the age of fourteen to that of eighteen, he had literally worked his way, teaching school at intervals, and receiving little or no aid from his family, through a career of honorable culture and attainment, which fitted him, in no unworthy manner, for the successful study of his chosen profession. In June, 1837, the supreme court admitted him to practice. He then removed to Newfield, in Maine, where he has ever since resided. From 1830, to 1833 , he was successively elected to the state legislature, a portion of which time he was speaker of the house. In 1834, he was appointed attorney-general of Maine 



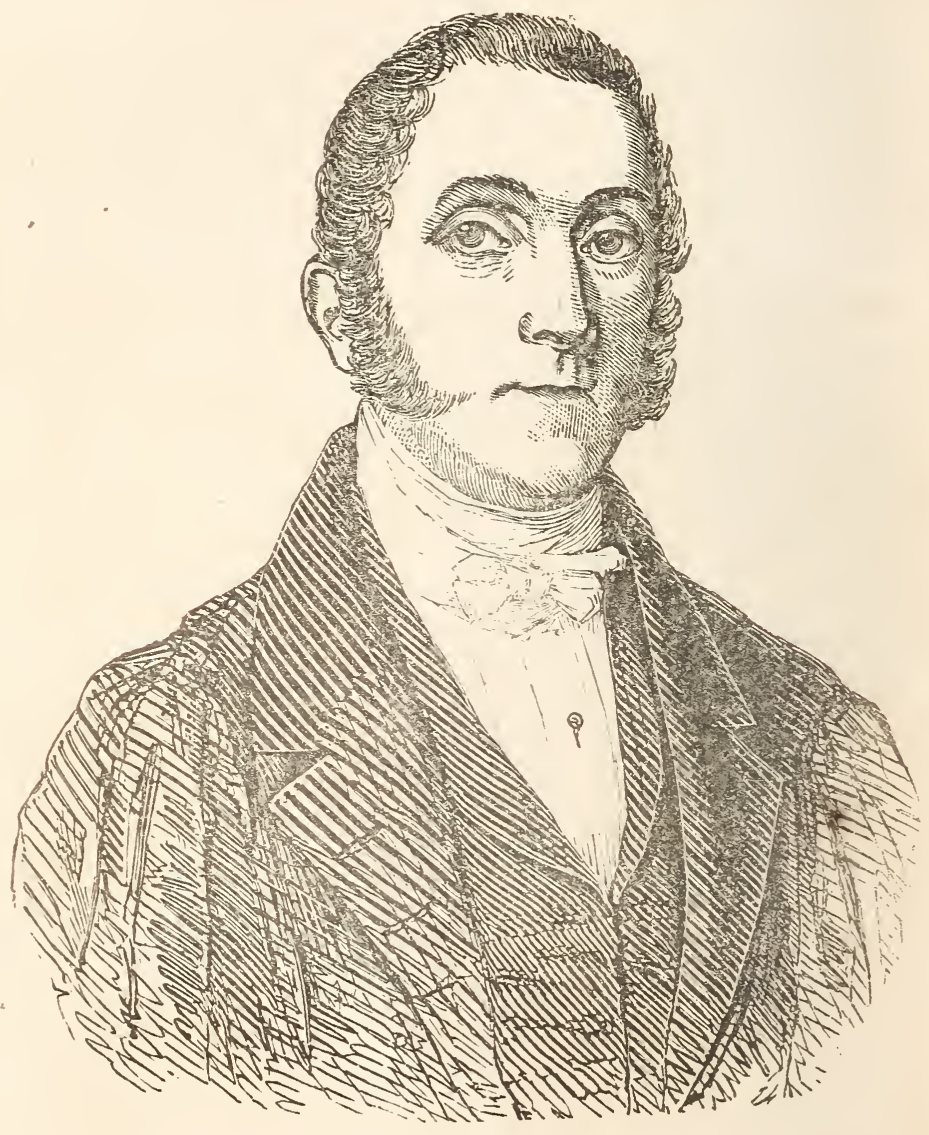

VALENTINE MOT T. 
He first took his seat in congress in 1839, and his second term embraced the three first sessions of the Tyler administration. In 1843, he retired from congress with a high reputation. He is now attorney-general of the United States.

\section{VALENTINE MOTT.}

With the exception of Alden March, of Albany, Prof. Mott has, it is believed, no equal as a surgeon, in the United States. He was born at Glen Cove, Long Island, on the 20th of August, 1785. His American ancestor was Adam Mott, who came from England and settled in Long Island, about the middle of the 17th century. Henry Mott, the father of Valentine, died at a very advanced age, in the city of New York, a few years since.

In 1807, Valentine went to London, where he became the pupil of Sir Astley Cooper, and attended the lectures of many other famous teachers of that day. Shortly after his return to New York, he was appointed professor of surgery in Columbia college, and subsequently to the same position in the College of Physicians and Surgeons.

In 1918, he performed the operation of tying the anterior innominata, within two inches of the heart. This was an original operation. It is said of him, that he has performed as many great operations as any man that ever lived.

In 1840 , owing to the delicacy of his health, he returned to Europe, traveling in England, France, and Egypt. On his return he published a book, containing notes of his travels. He is now professor of surgery in the New York university. 


\section{CHARLES HATHAWAY.}

It was the holy twilight hour, and clouds in crimson pride Sailed through the golden firmament, in the calm evening tide; The peasant's cheerful song was hushed, by every hill and glen; The city's voice stole faintly out, and died the hum of men: And as Night's sombre shades came down, o'er Day's resplendent eye,

A faded face from a prison-ship gazed out upon the sky; For to that face the glad bright sun of earth for aye had set, And the last time had come, to mark Eve's starry coronet.

Daniel Hathaway, the paternal grandfather of the subject of this notice, was of English descent, and was a native of Dartmouth, Massachusetts. His American ancestors were among the earliest settlers in the colonies. In 1776, Daniel entered the army of the revolution, as a surgeon.

He was afterwards taken prisoner by the Dutch, and confined in one of their loathsome prison-ships. After much suffering, he was, upon an exchange of prisoners, relieved, and with feelings which can easily be imagined, hastened homewards, to rejoin his sorrowing family:

I come, I come, like the weary bird, At eve to its sheltered nest;

Like the pilgrim from afar, I come

To a blessed shrine of rest.

Many a long day had he been expected, and many a sad sigh had been heaved at his continued absence. For

It is not home without thee-the lone seat

Is still unclaimed where thou wert wont to be;

In every echo of returning feet,

In vain we list for what should herald thee:

Father, come home! 
But alas! the light of life grew dim in that household, and the scalding tear fell, when the news came that their father had died on his way home, having, as there was strong reason to believe, been poisoned by the enemy at the last meal previous to his liberation!

Charles Hathaway, the oldest son of Isaac and Susannah Hathaway, was born in the city of Hudson, on the 4th of March, 1795. The only advantages he enjoyed, were those of an academical education; but he has nevertheless cultivated liberal studies, in which he has attained a considerable proficiency, and is, withal, a clear and vigorous writer. How many men thus situated, without the advantages of a college, have by a course of patient application, risen to the highest eminence and standing, and far above where the momentary sallies of uncultivated genius ever reach, have plucked from the lofty cliff the deathless laurel. In his early days he is represented to have been of a meditative turn, and fond of rambling through the meadows, into the most secluded and beautiful scenes, to "refresh his spirit with the sunshine, the green trees and bubbling waters."

Mr. Hathaway has resided in Delaware county, ever since he was twelve years of age, where he has had a respectable practice in his professional business as a lawyer. His principal employment, for many years, has been that of an agent for the proprietors of large tracts of land, in Delaware and some of the neighboring counties. In $1 \triangleleft 40$, he was appointed first judge and surrogate of Delaware county, which office he held, with great credit, for several years. He has at different times held other civil appointments. In 1844, the honorary degree of A. M. was conferred upon him by the trustees of William's college.

On the 16th of May, 1828, Judge Hathaway was united in marriage with Miss Maria Augusta 
Bowne, a sister of Norwood Bowne, Esq., the talented editor of the Delaware Express.

The personal appearance of the judge is gentlemanly and prepossessing, although, as a natural result of studious habits, his manner is rather reserved.

\section{ERASTUS BROOKS,}

Is a younger brother of James Brooks, of the New York Express. He was born at Portland, Maine, January, 1815. His father was captain of a private armed vessel, and, during the last war with England, succeeded in capturing several prizes. He finally perished, however, with his vessel, at sea. Erastus was born during his absence, and never saw him.

Sleep on, sleep on; the glittering depths

Of ocean's coral caves

Are thy bright urn-thy requiem

The music of its waves.

The purple gems forever burn,

In fadeless beauty round thy urn;

As pure and deep as infant love,

The blue sea rolls its waves above.

As might be supposed, from his great capacity for labor, the subject of our sketch commenced earning his living at a very early age. When little more than eight, when other children had but commenced going to school, he stood behind the counter of a grocery store in Boston. At twelve, he became a printer, and acted in the capacity of drudge in the office of the Portland Advertiser, the paper of which he afterward became editor! He remain- 
ed at the printing business until eighteen, when, assisted by his brother, he edited and published a paper at Wiscasset, Maine, called The Yankee. At this period he felt the necessity of a more liberal education, and accordingly commenced preparing himself for college. He commenced with Sallust, and simultaneously with his studies, he set his types, worked at the press, edited his paper, collected bills, etc., etc. By this means, he saved enough in one year to warrant his entrance into Waterville college, Maine. Here, and at New Hampton, in the woods of New Hampshire, he studied until his funds became exhausted. He then went to Haverhill, Massachusetts, where he worked three hours per day, setting types, for his board, and taught Greek and Latin to pay for his tuition. He thus pursued his college studies, and entered the junior class at Brown's university, Providence. He afterwards returned to Haverhill, where he taught school, and subsequently purchased and edited the old Haverhill Gazette, called the "old Essex junto organ." In the winter of 1835 , he went to Washington, where, during the sessions of congress, until very recently, he continued to reside. In 1836, he, with his brother, started the New York Express, with which paper he was connected until 1846, when he sold out his share. In 1843, he went to Europe. He traveled over England, Germany, Holland, Italy, Denmark, Sweden, Russia, Austria, Poland and France. His interesting letters, during that tour, were copied into nearly every paper in the Union, and proved him to be an acute observer, and a ripe historical scholar. In returning to the United States, in the packet ship Sheffield, after escaping so many dangers abroad, he had a narrow escape from shipwreck, when in sight of his native land, in addition to another in the British channel shortly after leaving Liverpool. On his return, he married an accomplished lady, the youngest daugh- 
ter of the Hon. Judge Cranch, of Washington city, a cousin of John Quincy Adams.

He has recently purchased the Pittsburg Gazette, the oldest paper west of the mountains.

Mr. Brooks is, in every sense of the word, a selfmade man. How little do men know of their own strength-of the deep spring and power of a determined will, until they are rudely forced to put forth their might - until a pressure of circumstances tries the elasticity of their spirits.

\section{ALBERT GALLATIN.}

This famous statesman and financier, the only survivor of the cabinets of Jefferson and Madison, was born in Geneva, in liberty-loving Switzerland, on the 29th of January, 1761, of a family that has always held a distinguished rank. At the age of eighteen, he graduated at the university of his native city. The narrow limits of the country of his birth, not affording sufficient scope for his energies and aspirations, he, contrary to the wishes of his family, emigrated to the United States, and landed at Boston, in 1780, bringing with him to the country of his adoption, an irreproachable character, and the warm regrets of his friends. He immediately joined Col. Allen, who was at the head of troops at. Machias, in Maine, and advanced funds for their support. In 1782, he was chosen professor of the French language, at Hanover university, Cambridge, Massachusetts; but, in the ensuing year, 1783, having received his patrimony, he proceeded to the state of Virginia, where he purchased several large tracts of land. In 1785, he purchased his farm at Fayette county, Pennsylvania; and in 
1789, he was elected a member of the convention for revising the constitution of the United States. During the same year, he was elected a member of the legislature, in which body he remained till 1793, when he was chosen a senator of the United States. But his eligibility to the office was contested, on the ground of his not having been a sufficient length of time a citizen of the United States. He lost his seat by a majority of one, a strict party vote-all the federalists voting against him, and all the republicans voting for him. During this year he married, in the city of New York, Miss H. Nicholson, the daughter of Commodore James Nicholson, a distinguished officer of the American navy, during the war of independence.

In 1795, he was elected a member of the house of representatives, where he became one of the most efficient leaders of the republican party. It was on his motion that the committee on ways and means was first organized, the house having, until that period, depended upon the treasury department for all information, and all investigation of questions connected with the public finances. This is a curious illustration of the manner in which almost every thing was left to the executive departments. He continued a member of the house of representatives till 1801, when Mr. Jefferson appointed him secretary of the treasury of the United States. He presided over the treasury department during the two terms of President Jefferson's administration; also, during the first, and the commencement of the second term of that of Madison; when he retired, to participate in the peace-making nogotiations of Ghent. In the words of a late writer, "it has always been the concurring testimony of all parties, that the treasury department has never been better administered than by $\mathrm{Mr}$ Gallatin."

The Emperor Alexander having offered his medi- 
ation between the United States and Great Britain, in 1813, Mr. Grallatin was appointed ambassador extraordinary to Russia, together with his distinguished associates. England, however, refused the mediation of Russia, but proposed to negotiate directly with the United States, upon neutral ground. Gottenburg was the place at first selected-subsequently, however, Ghent was fixed upon, and a treaty of peace was negotiated and signed at that place, by Mr. Gallatin and his colleagues, on the 24th of December, 1814. In 1815, conjointly with Messrs. Adams and Clay, he negotiated and signed at London, a commercial convention with Great Britain. In 1816, he was appointed ambassador to Paris, where he remained until 1823. During his residence at Paris, he was appointed on two extraordinary missions-one to Holland, in 1817; and the other to England, in 1818.

In 1824, he was nominated by the friends of $\mathrm{Mr}$. Crawford, as vice-president of the United Statesbut he declined the nomination. In 18:6, he was appointed minister to England. He returned to the United States in 1827, and has ever since resided in the city of New York.

In 18:30, he was chosen president of the council of the university; in 1831, president of the National bank; in 1843, president of the New York Historical society; and at different times, president of various other scientific and literary institutions. Since his residence in New York, he has published several learned works; and in 1846, appeared his remarkable and unanswerable letters on the Oregon controversy. On the subject of the currency, he has within the last few years, published some able and elaborate remarks, which are viewed as valuable contributions to the general discussion on the subject.

The author of the celebrated letters of "Curtius," speaking of Mr. Gallatin, says: "The accuracy of 
his information, the extent of his knowledge, the perspicacity of his style, the moderation of his temper, and the irresistible energy of his reasoning powers, render him the ablest advocate that ever appeared in the cause of truth and, liberty. He unites to the energy of eloquence, and the confidence of integrity, the precision of mathematics, the method of logic, and the treasures of experience."

Although now nearly ninety years of age, the countenance of Mr. Gallatin betokens great vigor, and his eye plainly indicates that the "lightning of the soul" is not quenched. He has a high and ample forehead, such as artists love to couple with the features of old age. With truth has it been observed, that this is the only feature of the human face which time spares. He dims the lustre of the eye-he shrivels the cheeks, and thins and whitens the hair-but the forehead, that temple of thought, is beyond his reach, or rather, it shows more grand and lofty for the ravages which furrowed it. The Democratic Review of 1843, in a very able notice of Mr. Gallatin, says:

"With respect to the estimation in which Mr. Gallatin was held, throughout his diplomatic career, we may safely say, that no American abroad, in that capacity, ever maintained a higher position, in every point of view. He was uniformly considered in the two great capitals of Europe, as one of the most distinguished members of the diplomatic corps. His eminent talents, extent and minuteness of general information, and fine conversational powers, could not fail, every where, to attract to his person the most distinguished social consideration; while, on the part of the governments to which he was accredited, the manly uprightness and good faith characterizing all his official conduct, in the full spirit of the American diplomacy, secured to him the highest respect and confidence." 


\section{JAMES GALLATIN,}

The son of Albert Gallatin, the subject of the preceding sketch, was born in the city of New York, on the 18th of December, 1796, in the house of his grandfather, Commodore James Nicholson. He graduated at Mount Airy college, Pennsylvania. In his seventeenth year, he accompanied Vice-President Dallas, as secretary attached to the extraordjnary embassy of the United States to Russia. He also assisted, in the same capacity, at the negotiation at Ghent, which resulted in the treaty of peace, signed on the 24th of December, 1814, by the plenipotentiaries of the United States and Great Britain. He remained attached to the American embassy at Paris, until 182:3, when, with a great accession to his knowledge of men and things, having seen every variety of character and society, in the principal cities of Europe, he returned to his native land. In the ensuing year, at the age of twentyeight, he married Miss R. Paxault, of Baltimore, Maryland. During the next eight years he was engaged in surveying and selling lands in the state of Ohio, and in the western part of the state of Virginia, by which he realized a considerable capital. The occupation of a surveyor, particularly in these portions of the country, must have been peculiarly pleasant to a young man of ardent temperament, and romantic disposition; and his rambles through the deep solitudes of the forest afforded him ample opportunities for studying the sublimities of nature, for to such

There is a pleasure in the pathless woods;

There is a rapture on the lonely shore;

There is society where none intrudes. 
With his means thus increased, Mr. Gallatin, in connection with his brother, established a banking house in the city of New York. In 1839, on the withdrawal of his father from the presidency of the National bank, in that city, he was unanimously elected president of that flourishing institution, which situation he now holds.

Mr. Gallatin is a ripe scholar, and well grounded in classical literature; in addition to which he is represented as possessing, in an eminent degree, the capacity and business talents of his honored parent. His manner is calm and natural, and free from that flutter and anxiety which never can be got rid of, by one unaccustomed to society, or who endeavors to appear what he is not. Yet his politeness is more "the sincerity of a good heart, than the etiquette of modern fashion." There is, too, an earnestness and good faith, that gives assurance of the high moral tone of his character, and the perfect integrity of his spirit.

May he live to the same good old age as his father; and when his course is run, may he be entitled to as green a garland. 
AMERICAN BIOGRAPHICAL SKETCH BOOK.

\section{EDWARD SANFORD,}

A senator from the first senatorial district of New York, was born in the city of New York. He is a son of the late Chancellor Sanford. After graduating at Union college, he studied law in the office of the Hon. Benjamin F. Butler, late attorney-general of the United States. He practised his profession for some years, in the city of New York, but a love of literature predominating, he became connected with the press. He successfully edited the Standard, and the New York Times. The latter was discontinued in 1837. It was an able democratic paper, but did not concur with the dominant party on the subject of the independent treasury.

Mr. Sanford went subsequently to Washington, and became one of the editors of the Globe; in which his smooth, flowery style afforded a curious contrast to that of the senior editor, Mr. Blair, which might well be compared to a torrent, dashing impetuously over every obstacle.

The manners of Mr. Sanford are bland and gentlemanly, and he has long commanded the confidence and respect of the party to which he is attached. Several pieces of his, which have at various times appeared in the periodicals, indicate that his poetical talents are of the first order.

He was recently nominated for the office of secretary of state of New York, but a division in the democratic ranks rendered his election impossible. 


\section{CHARLES ANTHON.}

Dr. Charles Anthon is the well known Jay professor of the French and Latin languages, in Columbia college, New York, and rector of the grammar school. If not absolutely the best, he is, says Poe, at least generally considered the best classicist in America. In England, and Europe at large, his scholastic acquirements are more sincerely respected, than those of any of our countrymen. His additions to Lemprière, are there justly regarded as evincing a nice perception of method and accuracy as well as of extensive erudition; but his Classical Dictionary has superseded the work of the Frenchman altogether.

Most of Prof. Anthon's publications have been adopted as text-books at Oxford and Cambridgean honor to be properly understood only by those acquainted with the many high requisites for attaining it. As a commentator, he may rank with any of his day, and has evinced powers very unusual in men who devote their lives to classical lore. His accuracy is very remarkable. In this particular he is always to be relied upon.

Dr. Anthon is, perhaps, forty-eight years of age; about five feet eight inches in height; rather stout; fair complexion; hair light, and inclined to curl; forehead remarkably broad and high; eye gray, clear and penetrating; mouth well formed, with excellent teeth-the lips having great flexibility, and consequent power of expression ; the smile particularly pleasing. His address in general is bold, frank, cordial, full of bonhommie. His whole air is distingue $\hat{e}$, in the best understanding of the termthat is to say, he would impress any one, at first sight, with the idea of his being no ordinary man. 
He has qualities, indeed, which would have insured him eminent success in almost any pursuit; and there are times when his friends are half disposed to regret his exclusive devotion to classical literature.

\section{ANDREW H. MICKLE.}

One of the good old features of a republic, is the unrestricted opportunity laid open to every man to earn for himself honorable distinction. The old couplet is none the worse for its age:

Honor and shame from no condition rise;

Act well your part-there all the honor lies.

Andrew H. Mickle, says the New York Sun, late mayor of the city of New York, commenced life a poor boy. He was born in a wretched one story house in Duane street, opposite the Sixth Ward hotel. At an early age he became an apprentice to Mr. Miller, the famous tobacconist, whose confidence he soon acquired, from his honesty, diligence and modest deportment. He soon became the foreman of that large establishment. At the death of Mr. Miller, the whole business was thrown into his hands, which he managed for the widow, with such strict integrity and success, that she received him as a partner in the concern. Some time afterward he married her daughter. Thus, step by step, he advanced to wealth, honor and reputation-and finally became mayor of this great city. On his retirement from that office, the New York Tribune contained the following notice of him:

"We cannot chronicle the retirement of Hon. A. H. Mickle, from the chief magistracy of our city, 


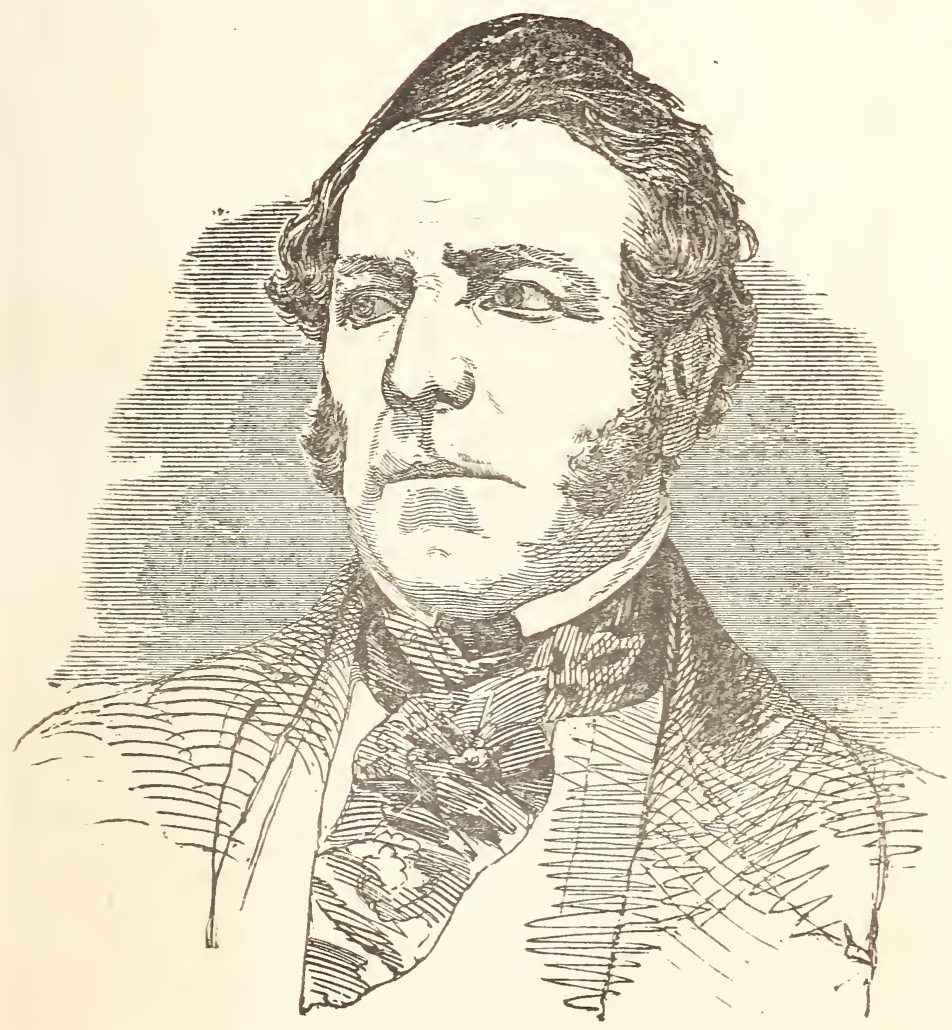

A N D R W H. MICKLE. 

without attesting the very general satisfaction which his official course has given, and especially the latter portion of it. Mr. Mickle came into the mayoralty entirely without experience, and for some time seemed unlikely to distinguish himself from the ephemeral shoal of mere creatures of party, whom the waves of political commotion are constantly heaving up to view and directly swallowing again. But he has proved himself of nobler metal than he was taken for, by laboring to discharge his duty conscientiously and impartially, destroying his chance for a renomination, but winning for himself an enduring place in the hearts of the discerning and the just. He retires from office with the profound respect and esteem of our whole city. Honor to his tried integrity and modest worth!"

\section{JAMES K. PAULDING,}

Was born in Dutchess county, in the state of New York, on the 22d of August, 1779. His ancestors were from Holland, and were of high character and respectability. In 1838, Mr. Paulding was appointed secretary of the navy, in which office he continued until the expiration of Mr. Van Buren's presidential term. But he is better known throughout the country as an author and poet, than as a statesman-his habits of retirement unfitting him for the stirring life of a politician. When at the head of the navy department, he was, it is said, so fond of shutting himself up in his private room, where he would lie upon his back for hours, in meditation, that he was almost inaccessible to persons having business with that branch of the government. 


\section{AARON WARD.}

Probably few men in the state of New York, are so widely known and universally respected, as Gen. Ward, of Westchester county. His history is interesting and valuable, and well worthy the study of young men. He was born in Westchester county. His father, Moses Ward, in the year 1785, purchased a part of the manorial estate of Frederick Phillips, which had been forfeited to the state by his attainder. This property covered a large portion of the site of the present village of Sing Sing, on the Hudson. At the time there were but three dwelling houses in this section of the country, one of which, an old stone mansion, used as a fortress to defend the settlers against the Indians, was the residence of Mr. Ward. His family was one of the oldest in the country, and took an active part in the revolutionary struggle. The mother of Gen. Ward was a niece of Col. Drake, of the continental army, and his father's uncle was an officer in Col. Philip Van Cortland's regiment, and fell at Saratoga.

Destined for the profession of the law, the subject of our sketch was placed at an early age, under the charge of the Rev. Mr. Nelson, a gentleman of great learning, and at the time, principal of the Mount Pleasant academy. He afterwards entered the office of Alexander McDonald, Esq., a lawyer of high standing and great worth. Shortly after this, the country became involved in the war with Great Britain, and with characteristic patriotism, young Ward left his law books, and devoted himself to her service. The secretary of war being in Albany at the time, Gov. Tompkins procured him a lieutenantcy in the 29th regiment of infantry, and presented it to him, with an order to report himself 
immediately for duty. Lieut. Ward, then in his eighteenth year, immediately repaired to Albany, and commenced his career as a soldier.

On his arrival at Albany, the governor tendered him the appointment of aid to Gen. Brown. But learning that a conditional promise of the same office had been made to Lieut. Spencer, (son of the late Chief Justice Ambrose Spencer,) notwithstanding the opinion of the governor that the post was his, Lieut. Ward regarding the claims of Judge Spencer on the executive as superior to his own magnanimously, declined in favor of Lieut. Spencer This brave officer fell at Lundy's Lane.

Gen. Tompkins then procured him a staff appointment in his regiment, but prefering active service, he was, at his own request, removed into the line. One or two incidents of his first campaign, will illustrate his character as a brave soldier.

In August, 1813, while the army under Gen. Hampton was on the march towards Montreal, Lieut. Ward, with a company of picked men, was sent forward as an advanced guard. Not far from the American lines they saw the enemy, and pressing on to meet them, were saluted with a sharp volley from an advance force. A second and third volley ensued, but nothing daunted, the gallant band pressed forward, until their young officer gave the word "Halt! ready my lads! steadily, coolly. Let every ball tell. Fire!" and springing to the front, he shouted, "Forward! quick march! charge!" The brave men, not a whit behind their brave leader, scattered the enemy like chaff. The rout was total, and the retreat of the British so prompt, that their dead and wounded were left on the field.

On the 25th of November, a division of the same army, then under command of Col. Purdy, broke up its encampment before sunset, with a view of reaching the Chateaugay river, in the rear of the enemy. They had orders to cross and commence 
the attack at one o'clock on the next day, at which time it was also to be made in front. The division being compelled to march through a dense forest, did not reach the ford in time. Brig. Gen. Izard commenced the attack, and drove the enemy from the out-posts. But finding that Col. Purdy, who had command of most of the light troops, could not bring his men into action, he withdrew his brigade, and orders were sent to Col. Purdy to construct a bridge and cross the river. But before this could be accomplished, the enemy fell on his command, threw them into confusion, and many of his officers fled ingloriously from the field. In this emergency, Lieut. Ward, with a few brave companions, uniting with Col. J. E. Wool and the officers in command, rallied the men and brought them into action. Lieut. Ward found himself at the head of a company of a hundred men, with only one officer to assist him. The enemy being repulsed, renewed the attack at ten o'clock P. M., and continued it till morning. The gallant conduct of Lieut. Ward during that fearful night, elicited the highest approbation of his superiors, and the next day he had the honor of leading the rear of the army safely into camp.

In 1814, he was promoted to a captaincy.

On the 29th of March in that year, the northern army under Gen. Wilkinson, concentrated at Champlain, preparatory to marching against the enemy, then in Canada, 2,500 or 3,000 strong. The march began at an early hour in the morning. Lieut. Scofield had been ordered to the right flank, with a command of fifty men. He was instructed to keep at a distance from the main body, to protect it against scouting parties of the enemy. He was attacked by an advance of the latter, who were securely posted in a forest near which the army should have passed, but for a mistake or the treachery of the guide. A halt was ordered, with a view of giving the advance, then two miles distant, an opportunity to counter. 
march, and the general in command, perceiving the exposed situation of Lieut. Scofield, sent Capt. Ward with a company to his support. Assuming the command, Capt. Ward made his position strong, and maintained it against a largely superior force; and ultimately, by a well-directed movement on their flank, he drove the enemy from their post.

At this time he received orders to maintain his position at all hazards; and he not only did so, but after a severe conflict, he compelled the enemy to retreat.

The limits of this sketch forbid our entering further into the military career of Gen. Ward. It will be sufficient to say, that he continued in the service till the close of the war, adding new laurels to those already won, and discharging every duty with rigid exactness, and in such a manner as to obtain for him the repeated approbation of superior officers.

At the close of the war, at the head of a battalion, he conducted the first detachment of British prisoners, numbering some six or seven hundred men, from Pittsfield, Mass., to Canada. His kindness to them on their march, in an inclement season, drew from them an expression of hearty thanks, and they begged him to accept a valuable watch, as a token of their esteem and gratitude. Capt. Ward was of course highly gratified by this unexpected tribute, but although he received their vote of thanks, and replied to it, he declined receiving the present with which it was accompanied. An offering of this kind, under such circumstances, was of far greater value than the gold snuff boxes, and diamond hilted swords, which it is customary for foreign potentates to present to our ministers.

The war being terminated, and his services no longer required, Capt. Ward resumed and completed his legal studies in the office of H.Van Derlyn, Esq., of Oxford; and on his admission to the bar, he returned to his native village, and commenced the practice of his profession. 
In January, 1820, he married the only daughter of Elkanah Watson of Albany, a lady who has always commanded, by her worth and amiability, the highest esteem of all who have the honor of her acquaintance. Mr. Watson is well known in the state, as a philanthropist of the noblest order.

Capt. Ward was soon afterwards appointed district attorney for Westchester county. On the 1st of September, 1824, he was elected colonel of a regiment in Mount Pleasant.

Devoting himself with patience and perseverance to his profession, he soon attained a high standing, which in connexion with his private worth, and great popularity in his county, soon removed him, in 1825, to a seat in the halls of congress. He was elected to represent the district composed of the counties of Westchester and Putnam, and was subsequently continued in that county for a period of twelve years, his last term expiring in 1843. This unusual length of time passed in Congress, proves how fully he possessed the confidence of his constituency.

The character of this work will not permit us to give more than a general review of the political career of Gen. Ward-probably the most interesting portion of his life. His career was in a period fraught with important and exciting incidents, and rarely equaled for the discussion of great and vital questions, bearing on the destinies of the county. Among these were-nullification, tariff, recharter of the United States bank, removal of the deposites, sub-treasury, etc.-with all of which Gen. Ward had an intimate personal connection; and to do justice to his labors would involve the necessity of writing a political history of the country during that period. He was a warm supporter of the administrations of Jackson and Van Buren. Not only were his efforts directed to the advancement of the interests of his constituents, but also those of neighbor- 
ing districts, as well as of the country at large. The city of New York is especially indebted to him for his exertions, in behalf of many important commercial measures then before congress. On all the leading measures for the defence and preservation of the Union, he uniformly gave his influence and vote.

One of his first efforts in congress was for his companions in arms, the defenders of Plattsburgand after a zealous advocacy of the bill for their relief, he had the satisfaction of seeing it become a law. He next united with the committee on revolutionary pensions, and advocated the pension bill with great force and eloquence.

He advocated the increase of the pay of the navy, and was instrumental in the passage of the bill, which placed that meritorious class of officers on a respectable footing. He was always on the military committees of the house, and thus had opportunities to be of service to the army and navy, whose firm friend he always remained. He urged the addition of the two regiments of dragoons to the regular army, and always strenuously opposed any attempt to reduce that force. The West Point academy is indebted to him for an inflexible friendship, which he always manifested, and which was successful in insuring for it the support of congress. He spoke often, and with great zeal, in its defence. One of his favorite measures, which he repeatedly but ineffectually urged on the attention of congress, was a plan for the education of the children of soldiers in the army.

On the 16 th of June, 1830 , he was elected brigadier-general, and on the 10th of February, 1835, was promoted by Gov. Marcy to the rank of majorgeneral-in which rank he is still continued under the new constitution of the state.

In 1846 , he was a member of the state conven- 
tion which revised the constitution, and in which he took an active part.

As a debater, Gen. Ward speaks with grace and fluency. Open, frank and courteous, he left congress with the cordial respect of all. Although ever faithful to his party, his gentlemanly course never gave his opponents reason to complain of a harsh word or a rude remark.

Gen. Ward is a devoted friend of literature, and has distinguished himself by continued exertions in favor of all institutions whose object is the promotion of knowledge. The village in which he re sides is especially indebted to him for these efforts. $\mathrm{He}$ is a warm advocate of the poor, and the oppressed, as all who know him will bear testimony. As a husband and a father, if we may be allowed to enter the hallowed circle of the family, he is said to be without a superior. The cares of public life, and the weight of political trouble, of which he has borne more than his share, have never been so great as to cause him to forget home, and its priceless treasures. He is still living, in the vigor and prime of life, and whether he remain in private life or not, long may he live to honor his name, as the soldier, the statesman, the philanthropist and the friend. 


\section{SAMUEL H. P. HALL.}

Senator Hall was born at Middletown, Connecticut, in 1804. His great-grandfather, on his mother's side, was the celebrated Jonathan Parsons, of Newburyport, Massachusetts, a distinguished divine, and whose name occupies a conspicuous place in the history of that time. The celebrated Whitfield died at his house. They are both buried under the church at Newburyport. The maternal grandfather of Mr. Hall was Samuel Holden Parsons, son of Jonathan, whose name he bears. Mr. Parsons was educated as a lawyer, and was a man of no ordinary talents. He settled at Danbury, in Connecticut, but subsequently removed to Middletown, in the same state. He there married Mehetable Mather, of Lyme, Connecticut, and by whom he had seven children. Soon after the commencement of the revolutionary war, congress appointed him a brigadier-general, and he mustered the state troops of Connecticut into the service of the general government, when they became continental troops. He was soon promoted to the rank of major-general, in which capacity he served his country during the war. He was a particular friend of Washington, who, in that time which tried men's souls, relied much on his judgment and advice. Gen. Parsons was one of the officers who composed the court martial that tried and condemned the unfortunate Andre. He was subsequently appointed a commissioner, and sent to the north western territory, on business of the government. After escaping so many dangers in his eventful life, he was drowned in the Great Bear creek, near its confluence with the Ohio river. How many, after coming out unscathed from amidst the shock of contending hosts, 
are found by death, in the quiet home where all appears secure! His widow survived several years, and was buried at Middletown, Connecticut.

Mehetable Parsons, daughter of the general, married Dr. William B. Hall, of Middletown, who was originally of Meriden, in the same state. He was a graduate of Yale College, New Haven. His father was a wealthy farmer of Meriden, and his grandfather was the minister at Cheshire, Connecticut.

Dr. Hall died at Middletown, in 1809, leaving two sons, William B., and Samuel H. P. Hall, the subject of our sketch.

$O$ weep not for the friends that pass

Into the lonesome grave,

As breezes sweep the withered grass

Along the restless wave:

For though thy pleasures may depart,

And darksome days be given,

Yet bliss awaits the holy heart,

When friends rejoin in heaven.

At the age of four years, Samuel was deprived of a father and protector, but he was blessed with one of the best of mothers, who spared no pains in instilling correct principles in the mind of her son. She was one of those who are aware that, as a straw will make an impression on the virgin snow, but after a time a horse's hoof cannot quench it, so it is with the youthful mind-a trifling word may make an impression, but in after years the most powerful appeals may cease to influence it. She was a mother to whom might well be applied the words of the poet:

She led me first to God;

Her words and prayers were my young spirit's dew,

For when she used to leave

The fireside every eve,

I knew it was for prayer that she withdrew. 
With truth has it been said, that integrity, unflinching perseverance in every sex-like duty, and a heroic spirit of self-sacrifice, whenever occasion calls for it, are transmitted traits in the women of that region.

Samuel was educated and provided for by his mother, until his age and qualifications enabled him to enter a store as clerk. Here the affability of his manner soon rendered him a general favorite, and possessing naturally great energy of character, and buoyant with health and hope, in the course of time he was enabled to commence business on his own account.

In 1826, he married Miss Emeline Bulkley, of Rocky Hill, Connecticut, the daughter of Charles Bulkley, Esq., of that place, and by whom he has had five children. His eldest son, Charles, is now at Yale college.

In the spring of 1837, Mr. Hall removed to Binghamton, Broome county, New York, where he has conducted a large and extensive mercantile establishment, with considerable success.

After holding several minor offices, he was, in 1846, nominated as state senator to the New York legislature, from the sixth senatorial district, comprising nine counties in the southern portion of the state. He received more than 25,000 votes, and a majority of over 1,700 over Judge Hawley, of Steuben county, the opposing candidate.

On the first day of January, 1847, Mr. Hall took the oath of office at Albany, and commenced his duties as one of the court of errors, which was then in session-and the little fatherless boy, who stood behind the counter, is now a senator!

Mr. Hall has very recently, by a large majority, been reëlected for another senatorial term.

It must not be supposed that Mr. Hall attained his present position without obstacles to surmount, and great difficulties to overcome. On the contra20 
ry, he has had an ample share of opposition. But he is not one of those people who, "having begun life by setting their boat against wind, and tide, are always complaining of their bad luck, and always just ready to give up, and for that very reason are helpless and good for nothing; and yet, if they would persevere, hard as it may be to work up stream, all their life long, they would have their reward at last. In the words of that pithy writer, John Neal, "Good voyages are made both ways. A certain amount of opposition is a great help to a man. Kites rise against, not with the wind. Even a head wind is better than nothing, No man ever worked his voyage any where, in a dead calm. The best wind for every thing, in the long run, is a side wind. If it blows right aft, how is he to get back?

"Let no man wax pale, therefore, because of opposition. Opposition is what he wants, and must have, to be good for any thing. Hardship is the native soil of manhood and self-reliance. He that cannot abide the storm, without flinching or quailing-strips himself in the sunshine, and lies down by the wayside, to be overlooked and forgotten. He who but braces himself to the struggle when the winds blow-gives up, when they have done, and falls asleep in the stillness that follows.

"Did you ever know any body stick to any kind of business, no matter how unpromising, ten years at most, who did not prosper? Not one! no matter how bad it might be at the beginning-if he stuck to it earnestly and faithfully, and tried nothing else-no matter how hard he may have found it sometimes to keep his head above water-still, if he persevered, he always came out bright in the end-didn't he?"' 
AMERICAN BIOGRAPHICAL SKETCH BOOK.

\section{VAN RENSSELAER ROWE.}

It has been truly said, that it is not always the men who shine with the most brilliancy before the world, and occasionally astonish our senses with their exploits, who are really the most useful or the most worthy. There are many whose lives afford but few incidents calculated to excite interest or allure attention, which are not, however, less worthy of record, or barren of utility.

Brought up from early youth to a life of labor, Mr. Rowe is, in the full sense of the word, a selfmade man. Blessed with fine health, a cheerful mind, and buoyant spirits, he is not one of that class who are always fancying that the world has gone particularly wrong with them, because of some trifling pecuniary loss, or the failure of some cherished speculation. Although from his boyhood temperate and economical, he did, on one occasion, when quite young, get intoxicated, "just to know how it would seem." But, notwithstanding the motive was only curiosity, the result was a week's illness, and he was so thoroughly dissatisfied with the experiment, that he never for once dreamed of its repetition. Would that thousands of others could be convinced by a single trial! The blossoms of paradise would burst forth before the waning of another moon.

About five years since, the subject of our sketch, having by his own unaided exertions secured an extensive and prosperous business, became convinced of the truth of those words, which floated on the breeze through the groves of Eden, more than six thousand years ago- "It is not good for man to be alone!" Under these circumstances he became united in marriage with Miss Helen Elizabeth 
McGregor, one of the accomplished daughters of Dr. J. B. McGregor, of Rochester, New York. How many now in the "sere and yellow leaf," wish that when young they had done likewise! $O$ aged bachelor, as your head falls back upon the pillow, do you not think-in a whisper be it spoken-how pleasant in those night solitudes, would have been the rise and fall of " a softer breathing than your own, the quick throb of a purer heart, imparting peacefulness to your troubled hours! Yet, as "the velvet moss will grow upon the sterile rock; the mistletoe flourish on the withered branch; the ivy cling to the mouldering ruin; the pine and cedar remain fresh and fadeless through the dying yearso even the remembrance only of a pure affection, like something green, something beautiful to see, and grateful to the soul, will, in the coldest and darkest hour of fate, still twine its tendrils around the crumbling altars, and broken arches, and desolated temples of the human heart."

Mrs. Rowe is, we believe, a native of Newport, New Hampshire; and with others of her sex, who are blessed with a keen perception of the beautiful in nature, is passionately fond of flowers, as the true emblems of loveliness and innocence, and the living types of all that is pleasing and graceful. Well might one of our gifted writers ask, "where would the poet fly for his images of beauty, if they were to perish forever? Do we not compare young lips to the rose? does not the winning eye gather its glow from the violet? and is not a sweet voice, like a breeze kissing its way through flowers? Sweet flowers! that bring before our eyes scenes of childhood-faces remembered in youth, when Love was a stranger to himself! The mossy bank by the wayside-the sheltered glen, darkly green, filled with the perfume of violets, that shone in their intense blue, like another sky spread upon the earth -the laughter of merry voices-the sweet song of 
the maiden - the downcast eye-the spreading blush - the kiss ashamed of its own sound-are all brought back to memory by a flower!"

Asking the indulgence of the reader, for this digression, we will conclude this sketch by saying, that eminently happy in his domestic relations, and honored by his fellow citizens, for his high integrity and sterling worth, Mr. Rowe still continues to reside at the city of Rochester, where may the music of its gushing waters, ever be a herald of pleasures to come.

\section{THOMAS W. OLCOTT.}

This gentleman is a descendant of Thomas Olcott, who was among the first settlers of the town of Hartford, and one of the founders of the trade and commerce of the colony of Connecticut. T: e precise period of his emigration from England is not known, but he was one of the "goodly company" of men, women and children, who in June, 1635, left Newtown, now Cambridge, and other settlements on the sea board of Massachusetts, to plant a new colony on the delightful banks of the Connecticut.

Mr. Olcott had been educated in Europe, a merchant, and in common with others he engaged in trade, for which Connecticut afforded great facilities, especially the traffic in furs.

There is no positive evidence as to the maiden name of Mrs. Olcott, but, says Mr. Goodwin, it is safe to conjecture that she was a Porter, from London, from the circumstance that, on the death of Mr. David Porter, of England, who was drowned in the river, while on a visit to the colony, letters of 
administration were granted to Mrs. Olcott. The following quaint exhibit of the expenses attending the funeral of Mr. Porter, shows that a custom, more honored in the breach than in the observance, then prevailed in the colony:

\section{JUNE 8, 1678.}

An accompt of what was expended on Mr. David Porter, for his taking up and burial.

By a pint of $\mathrm{Lyq}^{\mathrm{r}}$. to those that dived for him, - $£ 000100$ By a $\mathrm{q}^{\text {rt }}$. of $\mathrm{Lyq}^{\mathrm{r}}$. to those that brought him home, $\quad 000200$ By $2 \mathrm{q}^{\text {rts }}$. of wine and gall. of sydr. to $\mathrm{y}^{\mathrm{e}}$ Jury of Inquest, 000504 By $8 \mathrm{ga}^{\text {lls }}$. \& $3 \mathrm{q}^{\text {rts }}$. wine for the funeral, cost - $\quad 011500$ By a barr"ll. of syd ${ }^{x}$. for do. cost - - - - 001600

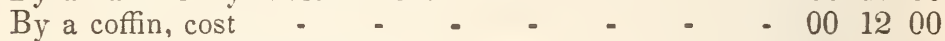
By a windeing sheete, cost - _ - - $\quad$ - 001800 By to pay for the grave, - - - - 000500

$£ 04 \quad 1404$

This given into the Court, at Hartford, December 9th, 1768, by the consent of my mother, Mrs. Abigail Olcott, per me,

Тно: Oг.сотт.

Mrs. Olcott died on the 26th of May, 1693, aged seventy-eight years.

The subject of this memoir, Thomas W. Olcott, is the son of Josiah Olcott, of Hudson, New York. $\mathrm{He}$ has for many years been president of the Mechanics' and Farmers' bank, of Albany, to which honorable position, by his high character and business talents, he rose from that of a junior clerk in that institution. A more public spirited man, or a greater and more efficient friend to all useful and benevolent enterprises, does not exist. With a clear head and a warm heart, he has been the mainspring of many a great movement, the influence of which shall reach beyond the grave.

On the 17th of August, 1818, Mr. Olcott was united in marriage with Miss Caroline Pepoon, of Stockbridge, Massachusetts, by whom he has had eleven children. 

Sarmul Gordon 


\section{SAMUEL GORDON.}

This distinguished man was born at Wattle's ferry, on the eastern branch of the Susquehannah, in the state of New York, on the 28th of April, 1902. His father, William Gordon, was a native of Massachusetts, and at the age of sixteen served in the revolutionary war, as a substitute for his parent, at North point, and in the valley of the Mohawk. He was in the battle at Canada creek, where Butler, a British officer, was killed by an Oneida Indian, in the service of the United States. He was a man of undaunted courage, daring intrepidity, and great physical strength; persevering and untiring in the pursuit of his object; a good judge of men and things, but of an irascible temper. He was a pioneer in the settlement of the Chenango valley, having moved into that region while the red man of the forest still made his abode there, and before there were any schools, roads, or public improvements of any kind. He went, with his wife and child, into the solitary wilderness, with none but the Indians for his neighbors and when the early settler was compelled at night to build a large fire at the door of his shanty, to keep off the wolves and other wild beasts. But with this temporarr dwelling, the sturdy axeman was content. With his rifle he procured abundance of food, and in process of time he soon became the possessor of a fine farm on the flats, at the ferry, where he died in 1825 .

Samuel received nothing more than a common school education, but it was remarked, that whatever he did learn, was grasped with "hooks of steel;" and he was one of those troublesome boys, who are always perplexing their teacher with the why? and the wherefore? His stern determination to attain 
an object, when once decided upon, was then, as now, a prominent feature in his charaeter. He was of a most stirring and enterprising turn, and any thing in which courage and endurance, whether of body or mind, were required, were the pursuits after which he panted. His love of argument rendered him a rather vexatious companion, to that class of his school mates who were ready to take every thing for granted. He was, in fact, it is presumed, the school lawyer; and from the well known impetuosity of his temper, there is but little doubt that he more frequently recorded his decisions with his fist, upon the bodies of the appellants, than by the more approved mode of pen and ink.

After leaving school, he was brought up as a farmer. This quiet pursuit, however, viewed as a mere mechanical employment, was far from being congenial with his active mind, and he was ever looking forward to the law. With this view, he was seldom without a book in his pocket, and before he was twenty years of age, he was a selftaught Greek and Latin scholar, and while breaking the stubborn soil, he was plowing deep into the mysteries of ancient lore. It was not, however, until his twenty-fifth year, that an opportunity presented itself for carrying into effect his long cherished wish to become a lawyer. He then, in 1827, bade adieu to the farm, and removed to Delhi, in Delaware county, New York, his present residence, where he became a student in the office of the late Gen. Root. So rapid was his progress, that in a very short time the entire business of the office was entrusted to him. In 1829, he was admitted an attorney in the supreme court of the state. He then became a partner with Gen. Root, in the practice of the law. This engagement continued until 1835, when Mr. Gordon continued the business on his own account. In 1831 , he was appointed postmas- 
ter at Delhi, which office he held until his resigna. tion, in 1841. In 1832, he was admitted a counsellor of the supreme court, and solicitor and counsellor in chancery. In 1834 , he was appointed district-attorney of the county of Delaware, the duties of which office he energetically discharged for three years.

In 1833, he was elected a member of the assembly of the New York legislature. While there, he made many able argumentative speeches. Among them was one in opposition to a bill for the abolition of capital punishment. So powerful was his reasoning, and so eloquently was it maintained, that to this speech the defeat of the bill, although ably defended by the Hon. John McKeon, and other distinguished speakers, was mainly attributed.

In 1840, Mr. Gordon was elected to congress from the twentieth congressional district, embracing the counties of Delaware and Broome. In 1844, he was again elected, by a considerable majority, over a very worthy gentleman of the opposite party, who was also his former competitor. This triumphant reëlection was considered as nothing more than a just tribute to "capacity, sound political views, and high personal worth." During the four years which Mr. Gordon served in the national legislature, he was a stern and uncompromising advocate of the interests of the masses, and always stood foremost in the defence of the laboring man. In the twentyseventh congress, amidst the greatest uproar and excitement perhaps ever witnessed in that body, he made a speech against the bill appropriating $\$ 25,000$ for the widow of the late President Harrison; and so little was he affected by the continued, almost deafening interruptions, that they were seldom afterwards attempted. He showed that he was not a man who would permit the freedom of speech to be put down by noise. In these attempts to get rid of a speaker by clamor, perhaps both parties are equal21 
ly guilty. When will the reprehensible practice be abolished?

At the first session of the twenty-ninth congress, Mr. Gordon spoke with his usual ability upon nearly all the great measures under consideration. His principal speech was upon the Oregon question, in which he strenuonsly advocated the validity of our claim to the whole territory. At the following session, he made the opening speech in favor of the Wilmot proviso, and he subsequently replied to the arguments on the other side. For both efforts he received the warm congratulations of his friends on the floor. Unlike some others, he went for the proviso without the least qualification; and the flattering testimonials he afterwards received from his constituents, showed that his course was heartily approved by them.

In 1842 , he was admitted an attorney and counsellor in the supreme court of the United States.

Of his ability as a lawyer, it is unnecessary to speak, as the numerous important cases which he has successfully conducted, will speak for themselves. Inheriting the irritable temperament of his father, he is an impassioned and zealous advocate, forgetting for the time every thing but the interests of his client, and in the performance of that duty, knowing neither friend nor foe. Keen, shrewd, active and persevering, he is the last man to be frightened out of what he conceives to be a duty.

For the information of the curious, it may be stated that Mr. Gordon is, beyond doubt, a lineal descendant of Lord George Gordon. Of this, however, he has never boasted, as he is one of those who hold that-

Not stars and titles make a lord;

$\mathrm{He}$ 's only noble who is good;

Kind hearts are more than coronets, And freedom's gifts than Norman blood. 


$$
\text { - }
$$




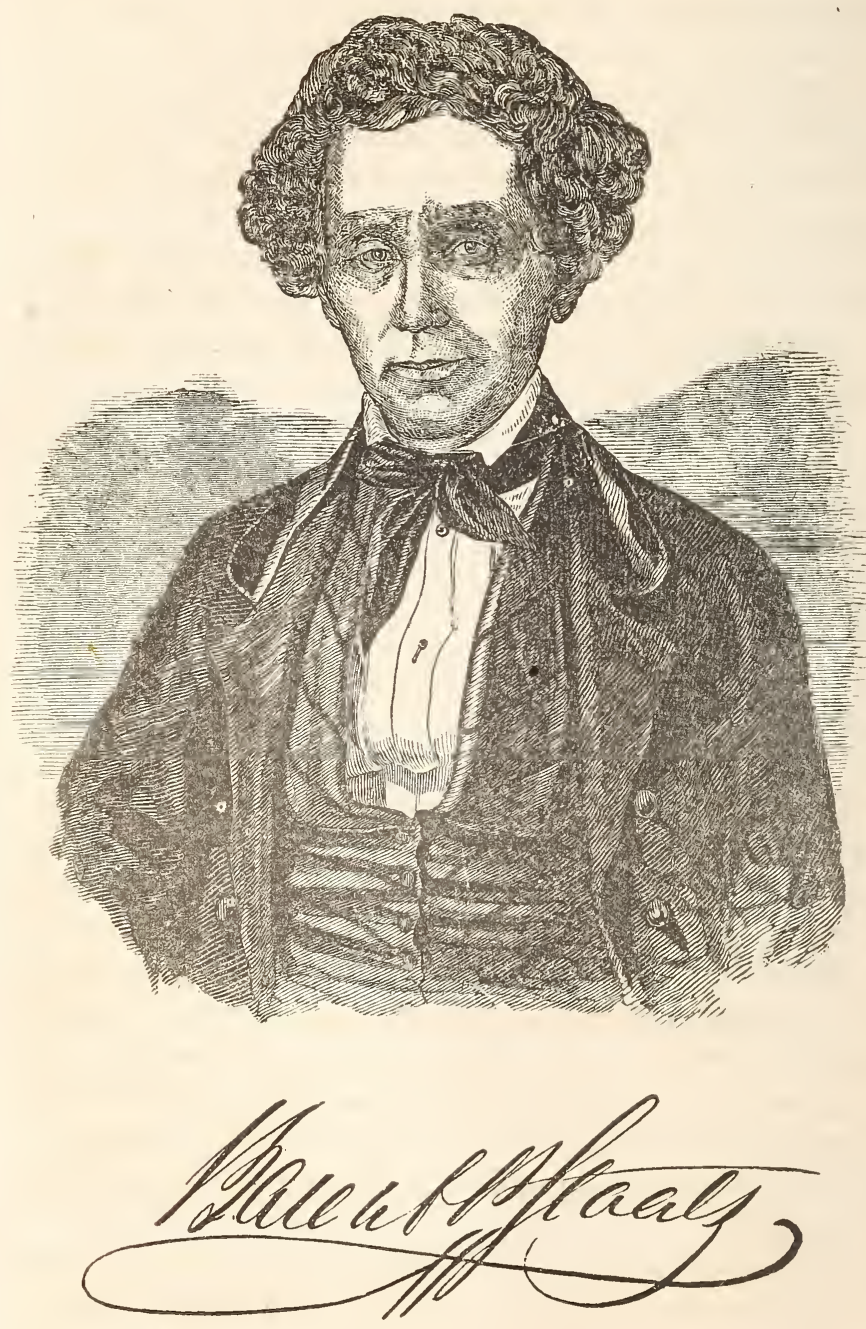


It has been well remarked, that however unimportant we may view such pretensions as are founded on ancestral worth alone, and however politic it may have been in a republican government to reject all claims to distinction, growing out of such a cause, we may still feel, and with propriety gratify a curiosity, as to the race whence our eminent public servants have drawn their descent.

In conclusion, it must not be supposed that Mr. Gordon is a bachelor. He, at the age of twentynine, married Miss Frances Leet, and he has several children.

\section{BARENT P. STAATS.}

This distinguished character, whose life we are about to sketch, is a striking instance of the truth of the remark, that the medical profession of the United States embraces within its circle, as much, if not more talent, than is to be found among any other class of men. It has been truly observed, that the perfect liberality of our institutions, both national and social, and the freedom of access to every situation in life, to the humblest individual, have produced among us a universal spirit of ambition, which brings forward the talents of all to the public service.

The paternal ancestor of Barent P. Staats, was Dr. Abraham Staats, who came from Holland to the city of Albany, New York, in the year 1642, and who, two years after his arrival, was appointed chairman of the council. The subject of this notice, was born in the town of Schodack, Rensselaer county, New York, on the 25th of Sep- 
tember, 1796. His father, Col. Philip Staats, was a brave officer of the revolution.

Barent, who at a very early age, manifested a great love of reading, received his academical education at Stuyvesant, Columbia county, New York, under the care of John Freeze. He afterwards studied medicine and surgery in the office of Dr. Joel A. Wing, of Albany, and at the Medical institute in the city of New York.

Among the numerous offices of honor and trust which he has held, are the following: President of the Albany County Medical society, three years; delegate and censor of the State Medical society, four years; health officer of the city of Albany, ten years; physician to the almshouse, five years; supervisor, eight years; alderman, three years; loan officer, eight years; president of the Albany County Mutual Insurance company, eleven years; director of the City bank, five years; he has been also a memter of the legislature, and mayor of the city of Albany. While in the legislature, so zealously were his duties performed, that he was never absent during a single vote. O that others would follow his example.

At his election as mayor, in 1842 , owing to his great personal popularity, he received an unprecedented majority of six hundred votes, over one of the best and strongest candidates of the whig party. During that year, the common council held thirty regular and thirty-one special meetings, from all of which he was never absent for one moment.

Having always been an active and warm friend to the temperance cause, he has for many years served on the executive committee of the New York State Temperance society. $\mathrm{He}$ is, it is believed, the only mayor in the state who refused to license grocers to sell ardent spirits, and his firmness in this respect will not soon be forgotten by the friends of the cause. 
This one act has raised him in the estimation of all good men, to a greater elevation than can ever be attained by courting popular favor, and prostituting the influence of office, for the purpose of securing a reëlection. Dr. Staats is one of those who remember that we live in a social world, in which we are not isolated beings, but are bound to each other by the most tender and endearing ties-that we are treading amid the most solemn relationsthat the thoughts we utter, the actions we do, are not like the waves, which leave no ripple-mark behind them, but possess a most energetic vitality, and live, either for good or evil, when the tongue is mute, and the hand is still.

His inaugural address, to the common council of the city of Albany, on the subject of licensing grocers, is a masterly production, and well worthy of perusal.

To him the city of Albany is indebted for many of its best improvements; and no one has done more to assist the young and enterprising than he. In him the sick and the needy, the poor and the oppressed, have ever found a ready helper.

He married in 1819, at the age of twenty-three; and has two daughters, of whom he has reason to be proud. His manners are affable, and his personal appearance extremely prepossessing. He is a close reasoner, and a good debater. His character as a physician is too well known to require comment. 


\section{THOMAS PRENTICE KETTELL.}

This talented writer is a descendant of one of the oldest families in Massachusetts. It is not ascertained, with certainty, that either of the pilgrims who landed at Plymouth bore the name, but it appears from the books of the church of Charlestown, a history of which has recently been published by the Hon. Mr. Buddington, that Reuben Kettell became a member in 1635 , fifteen years after the landing, and the name constantly recurs, as among new members, down to late dates. The paternal greatgrandfather of Mr. Kettell, the Rev. Thomas Prentice, whose name he bears, graduated in 1725; and a few years afterwards was settled at York, in the state of Maine, when he was soon afterward transferred to the church at Charlestown. He continued his pastoral duties at that place, until the edifice was destroyed by fire, at the battle of Bunker hill. After that event, and at a very advanced age, he preached in a log hut, built on the site of the church.

Rebecca, the eldest daughter of the venerable pastor, married Deacon Joseph Kettell, who settled in Boston, where his sons, Thomas Preston and John Kettell, became eminent. Thomas married Miss Hannah Davis, who acquired some reputation as a poetess, under the signature of Juliana. She was a granddaughter of Col. Davis, for a long period head of the selectmen of Boston, and judge of the supreme court. A niece of Mr. Kettell married a son of the late William Gray, whose world-wide fame as an eminent and successful mérchant, has reflected great credit on the Bay state. Her uncle, Hardy Pierce, was aid-de-camp to Gen. Gates, and was killed at the surrender of Burgoyne.

The subject of this memoir, was born in Boston, 
in 1811. He was the second son of Thomas Prentice Kettell. After receiving a mercantile education in the store of J. \& E. Phillips, sons of Lieut.-Gov. William Phillips, he travelled some years in Europe; but meeting with ill success in commercial pursuits, he returned to the United States, and adopted New York as his home. Here circumstances brought him into connexion with the press, at a time when a long period of speculation throughout the commercial world, had just suffered a revulsion, and when an over wrought banking system was falling into decay. Bringing the experience of great commercial connexions, and a clear judgment, with much financial tact to bear upon the nature of the case, he soon earned for the "money articles" of the Morning Herald, published by James G. Bennett, a great reputation, both at home and in foreign countries. The clearness of his diction, the accuracy of his views, and the sagacity of his remarks, fully and promptly sustained by events as they transpired, fixed the attention of the commercial public, and rapidly increased the circulation of the paper.

The interest which Mr. Kettell imparted to the subject of financial reports, caused them to become an essential feature of every daily paper.

In 1840, his connexion with the Herald having ceased, Mr. Kettell started the Gazette, a daily journal, advocating the principles of free trade, of which he has always been an ardent and efficient supporter. Difficulties, however, arising with the publisher, amidst its dawning prosperity, the paper was abandoned. Mr. Kettell then edited the Morning News, until he took charge of the Democratic Review, of which highly popular publication he is at present sole editor.

The personal appearance of Mr. Kettell is prepossessing. His height is about five feet nine inches. He has a well-formed intellectual head. His fore- 
head is capacious. He is more of a political economist than a literary man. His brother, the Rev. G. F. Kettell, is pastor of the Vesey Street church, in New York city.

\section{AMOS DEAN.}

This gentleman is favorably known among a Jarge portion of the community, as the principal originator of the Young Men's association at Albany; an institution which embraces in its circle, the very highest order of talent. He is the son of $\mathrm{Na}$ thaniel and Rhoda Dean. His father was born at Hardwick, Massachusetts, in April, 1767, and when about twenty years of age, he emigrated to Barnard, Vermont, and was among the early settlers of that town. The maiden name of his mother was Rhoda Hammond. She was the daughter of Jabez Hammond, and was born at New Bedford, Massachusetts, in April, 1771. About seven years afterwards, she removed with her parents to Woodstock, Vermont. She is the direct lineal descendant, in the fifth generation, from Admiral Penn, whose daughter Elizabeth, the sister of Sir William Penn, married William Hammond, of London, England, and who, after his death, in 16:34, removed with her son Benjamin to Boston, where she died in 1640 .

After their marriage in 1801, the parents of $\mathrm{Mr}$. Dean, settled on a small farm, in an obscure part of Barnard, an uneven, hard-favored, rocky township, being in a primitive region, and abounding in all its peculiar characteristics. His father purchased the farm, then covered with an unbroken forest, for a hundred pounds sterling. By his own efforts he cleared it, and in due time realized the amount of 

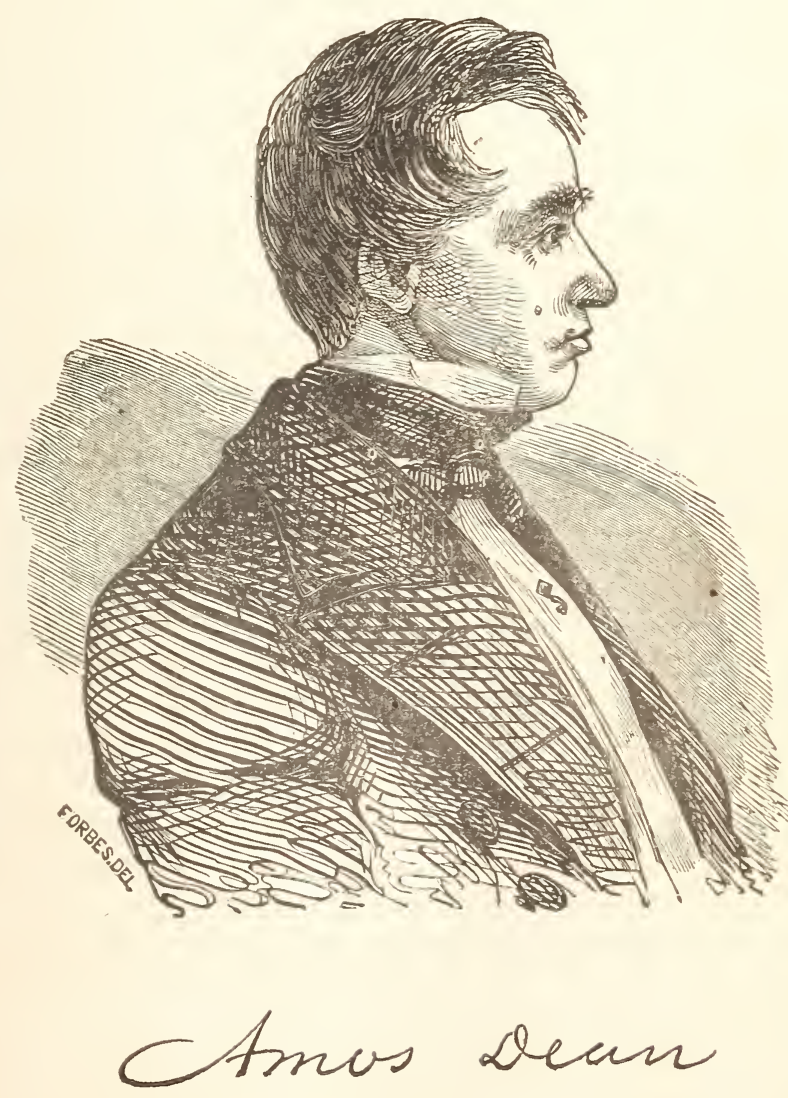

the purchase money. This, however, required the patient industry of many years to accomplish; but what will not singleness of aim, unity of means, and steadiness of purpose effect?

Amos, who was the eldest son, was born on the 16th of January, 1803. Born and nurtured among the mountain evergreens, which still continue to overspread so great a portion of Vermont, and with no early school facilities, his opportunities for mental culture, were of the most slender kind. It was his good fortune, however, to be blessed with a mother, who was a woman of superior mind. She had been a school mistress, and knew that children had minds as well as bodies. Hence she readily fostered the strong inclination, which her son manifested for the acquisition of knowledge. Although her time was necessarily occupied by her industrial pursuits, she was nevertheless his first and best instructress.

An attendance upon a district school of some three months, during about five successive winters, enabled him to acquire the rudiments of a common education. He also had access to an old town library, consisting mostly of theological works, and some books of travels and historical works. Ardently loving knowledge for its own sake, he thus acquired an early taste for historical reading. In his eighteenth year, while laboring upon the farm, he managed to acquire a respectable stock of Greek and Latin. He also taught school during the following winter months, the avails of which he was suffered to retain. These small means enabled him to spend a few months at the academy in Randolph, Vermont, the only institution of the kind he ever attended.

In the autumn of 1825 , Mr. Dean entered the senior class in Union college, having previously bought of his father his twenty-first year, to the services of which the latter was legally entitled. 
The consideration was, a release to the father, of all claim the son might ever have to the property as heir at law, one of the first and best bargains he ever made. Having graduated in July, 1826, Mr. Dean returned to his native town. In the fall of that year, he accepted the invitation of his maternal uncle, the Hon. Jabez D. Hammond, (author of the Political History of New York,) to remove to Albany, and to enter the office of the latter, as a student at law. Mr. Dean has frequently remarked, that had it not been for the substantial aid and encouragement of this relative, he could not have persevered through the trials and difficulties, with which he had to contend.

In the May term of 1829, Mr. Dean was admitted as an attorney in the supreme court of the state of New York. Ever since that period he has continued in the successful practice of his profession at Albany.

In April, 1833, Mr. Dean delivered the annual address before the Albany Institute. The subject was the Philosophy of History. The address was printed, and extensively copied by the press. It was in the fall of that year, that his attention was drawn to the principle of association, for the purpose of social, moral, and intellectual improvement; and with the aid of a few others, he succeeded in getting up, and establishing upon a permanent footing, the Young Men's association for mutual improvement, in the city of Albany. This is justly claimed to be the first institution of the kind, that ever existed in this country. Of the fruits which it has already borne, and of the many prominent public men, who, but for its beneficial influence, would have remained in obscurity, it is unnecessary to speak.

Mr. Dean was its first president, and reëlected for a second term. The institution has been incorporated, and is in a very flourishing condition, 
and associations of a similar character are now in operation in nearly all the cities and villages of the state.

In 1840, Mr. Dean presided at a convention of Young Men's associations of the state of New York, held at Utica. The result was, an organization of the whole into a state association, of which $\mathrm{Mr}$. Dean was elected president, and he delivered the first annual address.

Some years since, Mr. Dean delivered before the Albany association, a very interesting course of lectures, on the subject of phrenology. The lectures were published, and furnished an ample theme for discussion, among that class who are apt to condemn every thing that is new. In 1839, he had published in Boston, the Philosophy of Human Life, being an investigation of the great elements of life. This was a very elaborate work, but adapted to a class of readers and thinkers, not very numerous in this country. He also published a very valuable practical work, entitled a Manual of Law, for the use of business men.

On the 5th of October, 1840, Mr. Dean delivered before the State Agricultural society, a eulogy on the occasion of the death of the late Jesse Buel, and which was afterwards printed by the society. In July, 1840, he delivered the first annual address before the senate of Union college.

In the fall and winter of 1838 and 1839, he was instrumental, with sorne others, in establishing the Albany Medical college. At the commencement of that institution, Mr. Dean received the appointment of professor of medical jurisprudence, a department in which he has continued to lecture at every term since its organization. In 1840, Prof. Dean published a Manual of Medical Jurisprudence, designed solely for the use of the classes attending his lectures.

On the 14th of September, 1צ42, Prof. Dean was 
united in marriage with Miss E. Joana Davis, of Uxbridge, Massachusetts. How needful is the smile of woman to gild the laurels of the brave, and to cheer the labors of the wise!

\section{SILAS WRIGHT.}

It has been truly observed, that honor and fame are the legitimate reward of virtue and talent; and that beneficially placed within the reach of all, they appear like trophies, to be won and worn, by those who successfully contend against indolence and vice. An attestation of this truth will be found in our brief sketch of the late Silas Wright.

He was born at Amherst, Massachusetts, on the 24th of May, 1795. In 1815, he graduated at Middlebury college, Vermont. In 1819, he was licensed to practice law in the supreme court of the state of New York. He then removed to Canton, St. Lawrence county, where he continued to reside until his death. At that time the village was new, and the business in the courts very limited and unprofitable. A client was almost as rare as snow in harvest, and the fees were not by any means of such a character as to cause the farmers to envy the lawyers. All his father was able to advance him, was $\$ 200$, onehalf of which Silas expended in the purchase of a few books, while the other half was reserved to meet his more immediate necessities. "We can easily imagine," says the Democratic Review, "how forlorn must have been the condition of young Wright, in this, the commencement of his professional career, without property, or any relations or friends near him, and surrounded by strangers, and when he saw that he must rely solely on his own 

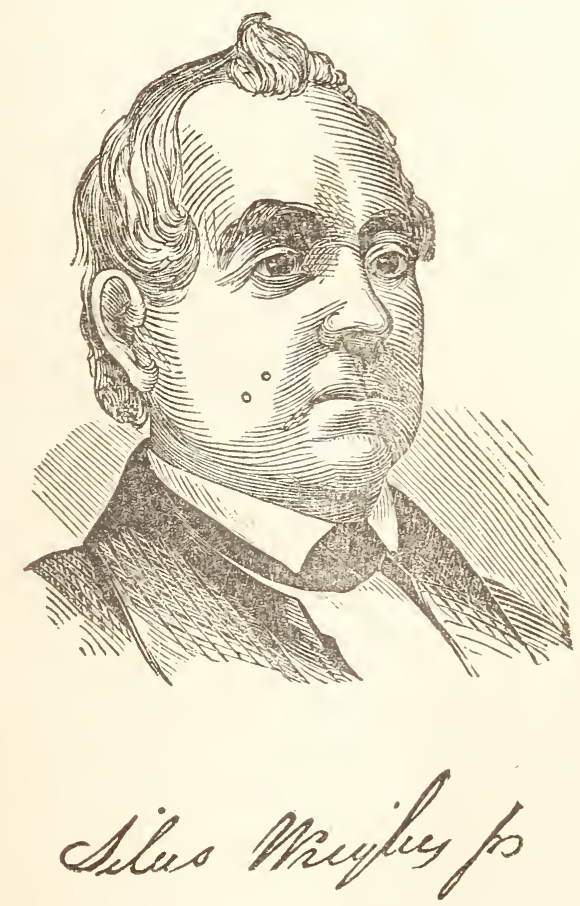

efforts and merits to sustain himself. Yet we do not doubt, could the truth be known, that in this trying crisis, he found precious consolation in the conviction, that he must rise by the force of his abilities to distinction. It is this early suffering and training, that prepares men of great talents to make their way good up the steep and rugged ascents of fame."

Finding that his small means were rapidly wast. ing away, he accepted the office of village post. master, which brought him nearly two dollars per week. This small sum served to pay his board, and to "keep the wolf from the door," so that he took heart, seeing as it were a faint streak of the coming sunlight gradually breaking upon him.

Shortly afterwards, charmed by his winning man. ner, and social qualities, his fellow citizens elected him a militia officer; and it may be easily imagined from his well known disposition, that he was never asked "to resign."

In January, 1824, he took his seat in the state senate, and in 1827, he was elected to congress. In 1829, while in the discharge of his duties at Washington, he received the appointment of comptroller of New York, which office he held for three years. In 1832, he was again elected to congress. In this year, owing to the election of Wm. L. Marcy, as governor, Mr. Wright was elected to succeed him in the senate. His term expired in March, 1837, but on the first term of the preceding February, he was reëlected for the constitutional period of six years.

After the close of the twenty-seventh congress, the forlorn young village post-master, who rejoiced at his two dollars per week, became governor of the state of New York.

On the 1 st of January, 1847, he retired to private life, in the village of Canton, where he resided in his small wooden house, until the evening of the 27th of August, when he was suddenly called to 
that "house not made with hands, eternal in the heavens."

Now that he is gathered to his fathers, and the bitterness of party spirit is lost in the grave, all are willing to acknowledge his merits and patriotism. From his tomb fresh laurels will spring up, and mingle their odor with the evergreens of enduring fame.

\section{FREEMAN HUNT.}

This self-made man, who, through his popular magazine, is known in every part of the world, is a native of Quincy, Massachusetts. He was born on the 21st of March, 1804. He is one of those who attach no great importance to ancestors, only so far as their virtues may be inherited. On his mother's side were the Turners and Stetsons, who left England in 1630, and settled at Scituate, near Plymouth, Massachusetts. His father, Nathan Hunt, was a shipmaster, and died when Freeman was only three years of age. The latter chose the printing business, as being the best adapted to the acquisition of knowledge that his circumstances, and those of his mother, would permit. During his minority, he had a good deal of up-hill work to perform, and experienced not a little of the rough and tumble of the world. But his motto has always been-"Hope on, forever"-and through Providence, which ever provides for those who provide for themselves, he is now in very easy circumstances. He has no debts, although he has paid not a few for others, and he has enough of this world's goods to make him and his comfortable. His ideas of enough, however, are not quite so ex- 
travagant as some of his fellow citizens, who by their actions, do not appear to be aware that there is such a word in the language, and he is ever ready to share a dollar with those who need it more than himself.

Our grave subject, facetiously says the New York Evening Mirror, is a cross between an author and a merchant; he has not the carelessness of the one, nor the primness of the other, but a mixture of the two. He is the proprietor and editor of that unique periodical, the Merchants' Magazine.

Like Yankee boys in general, he pricked up the rudiments of an English education at a country school, and was apprenticed to a Boston printer at the age of fourteen. A printer's trade, a common education, and a brave heart, have formed the sole capital of many a great man in the republic. Freeman Hunt, like Benjamin Franklin, and many a true man besides, with these simple elements, has achieved a position in the world, and kept his honor untarnished. No sooner was he out of his time, than he began to think of establishing himself in the world; and instead of squatting upon soil which another man had cleared, with the true energy of a Yankee, he looked about him for a spot which no man had yet improved-a no-nian's land -that he could claim for his own by right of prior discovery. At that time there was not one of those, now numerous publications, called ladies' magazines; and with a true insight into the wants of the reading public, he projected a periodical similar to the Lady's Book, which, we believe, he called the Lady's Magazine. Mrs. Sarah J. Hale was just attracting notice by her first novel, and Mr. Hunt purchased the use of her name as editress. The magazine succeeded, but did not satisfy the ambition of the proprietor. He sold out, and began the republication of the Penny Magazine, which reached a sale of 5000 numbers. This work he soon 
abandoned, and the Berwick company being got up by an association of authors, artists, printers and bookbinders, whose object was the publication of their own works, he took charge of it. Mr. Hunt was the managing director, and displayed wonderful talents at financiering, for as the association had nothing but talents and genius, it required no ordinary degree of financial skill to exchange their products for grosser materials, without which they could do nothing.

While in the management of this company, he projected the American Magazine of Useful and Literary Knowledge, and conducted its editorial department while he remained with the company, which was dissolved soon after he left it.

He then got up two volumes of American Anecdotes, which were highly successful, and have formed a magazine of wealth for succeeding book makers; then, the American Pulpit, an episcopalian periodical.

In 1831, he removed to New York, and established a weekly newspaper, called The Traveler. In 1834, he published a Comprehensive Atlas, which was very successful. Afterwards he wrote letters to some of the Boston papers, and published a popular work called Letters about the Hudson, which passed through three editions.

His next enterprise was the Merchants' Magazine, a work entirely original in its plan, and which was successful from its start. By his singular tact, good management and industry, he has built up a work on a plan which is so obviously right now, that people wonder it was never done before.

The' success of Mr. Hunt is a remarkable instance of what may be accomplished by patient perseyerance, and honorable conduct; and his example should serve to stimulate the exertions of the thousands of young men who are daily launched upon 
the world to seek their fortunes, with no other capital than their strong arms and honest hearts.

We believe that Mr. Hunt has never taken an active part in partizan politics; he has, however, been a firm and consistent advocate of free trade since the commencement of his magazine, and is one of the sound writers on political economy which this country has produced.

Mr. Willis, in particular, has made him the subject of repeated comment. He says, in the Mirror:

Hunt has been glorified in the Hong-Kong Gazette, is regularly complimented by the English mercantile authorities, has every bank in the world for an eager subscriber, every consul, every shipowner and navigator; is filed away as authority in every library, and thought of in half the countries of the world, as early as No. 3, in their enumeration of distinguished Americans-yet who seeks to do him honor, in the city he does honor to? The Merchants' Magazine, though a prodigy of perseverance and industry, is not an accidental development of Hunt's energies. He has always been singularly sagacious and original in devising new works and good ones. He was the founder of the first ladies' magazine; of the first children's periodical; he started the American Magazine of Useful and Entertaining Knowledge; compiled the best known collection of American anecdotes; and is an indefatigable writer-the author, among other things, of Letters about the Hudson.

Hunt was a playfellow of ours, in round-jacket days, and we have always looked at him with a reminiscent interest. His luminous, eager eyes, as he goes along the street, eagerly bent on his errand, would impress any observer with an idea of his genius and determination, and we think it quite time his earnest head was in the engraver's hand, and his daily passing by, a mark for the digito mon- 
stan. Few more worthy or more valuable citizens - are among us.

He is earnest, eager, combining in a very singular manner, general coolness and occasional excitability. He is a true friend, and the enemy of no man. His heart is full of the warmest sympathies and charities. No one in New York is more universally popular. And it is worthy of remark, that in striving to build himself up, Mr. Hunt has never endeavored to pull others down. His doctrine is, "Live and let live."

He is about five feet eight inches in height, well proportioned; complexion light florid; forehead capacious; chin massive and projecting, indicative (according to Lavater, and general experience) of that energy which is, in fact, the chief point of his character; hair light brown, very fine, of a web-like texture, worn long, and floating about the face; eyes of wonderful brilliancy, and intensity of expression; the whole countenance beaming with sensibility and intelligence.

$\mathrm{He}$ is married, and nearly forty-four years of age. 


\section{SAMUEL FINLEY BREEZE MORSE.}

"Franklin drew the lightning from heaven, but Morse gave it a voice," was the eloquent remark of one, who with others, gloried in claiming this celebrated professor as an American, whose name shall go down to posterity, as the founder of a new era in the transmission of intelligence. And truly, when the nations shall converse across their oceans, and the winged words shall fly to the ends of the earth, uniting the whole human race in a circle of knowledge, conveyed in "one language and one speech," then shall the name of Morse be recorded, when those of heroes and emperors shall have been lost in the vortex of revolutions.

Prof. Morse was born on the 27th day of September, 1791, at Bunker Hill, Charlestown, Massachusetts-the great battle-ground, famous forever in the annals of our country. He is the son of the late Jedediah Morse, the father of American geography, and the great-grandson of the Rev. Dr. Samuel Finley, president of Princeton college, New Jersey. He was educated at Yale college, where he graduated in 1810 .

In the following year he went to London, to cultivate a taste which he had acquired for the fine arts. He resided there for four years, and was a pupil of those distinguished masters, Washington Allston and Benjamin West. During this period, he produced many choice paintings, and received a gold medal for the best specimen of sculpture. The subject was, the Dying Hercules. This was his first effort in sculpture. At the same time, he had several paintings in the Royal exhibition.

In 1815, Mr. Morse returned to his native country, and occupied his time for seven or eight years, 
chiefly at the south, as a portrait painter. But higher honors awaited him. In 1824, or 1825, he was the prime mover and getter-up of the $\mathrm{Na}$ tional Academy of Design, of which we have just reason to be proud.

In 1829, the subject of our sketch again visited the old world, and remained in Italy and France, pursuing his studies in the fine arts, until 1832. During a considerable portion of this time, he resided in Rome, Florence and Venice. He returned from Havre to America, in the packet-ship Sully, and on his passage his active mind conceived the idea of the electro-magnetic telegraph.

All the telegraphs in Europe, which are practicable, are based on a different principle, and, without an exception, were invented subsequently to his. Says Prof. Morse, in a letter to Stephen Vail, E:q.:

"The thought occurred to me in general conversation with the passengers. I ought perhaps to say, that the conception of the idea of an electric telegraph, was original with me at the time, and I suppose that I was the first that ever associated the two ideas together. Nor was it until my invention was completed, and had been successfully operated through ten miles, that I, for the first time, learned that the idea of an electric telegraph had been conceived by another. To me, it was original, and its total dissimilarity to all the inventions, and even the suggestions from others, may be thus accounted for. I had not the remotest hint from others, till my whole invention was in successful operation."

The claims of Prof. Morse are now universally acknowledged, and at a very recent meeting of the British Association for the Promotion of Science, Sir Robert Inglis, the president elect, admitted that to the United States belongs the honor of having first successfully introduced the electric telegraph.

The personal appearance of Prof. Morse bespeaks 
the philosopher. He is tall and slender, has an intellectual forehead, and the snows of time have slightly sprinkled his hair. A more unassuming man cannot be found; and, had it not been for his extreme modesty, congress would have employed him to construct the first experimental line, between Washington and Baltimore, at a much earlier period than they did.

He is not a man of ordinary mould, for were we to deprive him of his imperishable honors as the discoverer of the telegraph, we must, as an artist, still place him high on the pedestal of fame.

\section{GRANT THORBURN,}

Upon the incidents of whose eventful life, Mr. Galt founded his immortal story of "Lawrie Todd," is still living, at Astoria, Long Island. He landed at New York on the 16th of June, 1794, with only three cents in his pocket. His trade was that of a wrought nail maker. At that time, cut nails were not manufactured in the United States. "In a few years, however," says he, in a letter to a friend, "the cut nails cut me out of employment. I then for some years kept a retail grocery; but a friend, having a heavier purse, and more knowledge of the business, commenced the same trade beside me, and cut me out of that also. I then painted the common earthen-ware flower pots with green varnish. This was in 1799. The pot painting soon became a thriving business. One day in April, $1800, \mathrm{I}$ for the first time observed a man selling plants at the Old Fly market, at the foot of Maiden lane. In passing in a careless manner, I took a leaf from a plant, and was surprised to find a green 
leaf smell like a rose-bud. I asked its name. The owner replied, 'a rose geranium.' It was the first time I had heard the word pronounced-the first time that I knew there was a geranium in the world. By means of this plant, Providence led me by a way I knew not, into the seed business. It was a fine, healthy plant, and thinks I to myself, it will look well in one of my green varnished pots, to stand on my counter and draw attention. I had no intention to sell it. Next day, however, some person purchased both plant and pot-and I cleared twenty-five cents by the speculation. On the following market day, I purchased two plants, put them into green pots and sold them. In a few weeks my stock of plants numbered two dozen. I erected a stage inside the door facing the street, and they made quite an imposing appearance. It drew attention. It was something new under the suna man selling plants in a store. Our citizens, when showing their country friends the wonders of our wonderful city, would pilot them at times to see my plants. Certain ones among them, would very much wish to take home with them, 'this rose,' 'that geranium,' or 'the beautiful myrtle by its side'-but after getting to the landing, they had forty miles land carriage, and it would get broke in the wagon. Then they would ask for the seed of the plant. On other occasions, they would ask for radish, cabbage, or any other vegetable seed they thought of. These inquiries'were perhaps made some hundred times, before the idea of selling seed entered my mind. At length, thinks I, why not sell seeds as well as flowers? Here was the rub. No one saved more than he wanted for his own use, and there was no market for them. Perhaps one farmer raised too much beet, so he would exchange with him who raised an overplus of carrot seed, etc.

"By this time I and my friend the gardener, from 
whom I obtained the plants I sold, were getting to understand one another. He kept his plants, etc., on the ground, in Brooklyn, since known as the military garden. I consulted him in the matter, and, says he, I am now raising seeds to sell next spring in the market, along with my plants, but if you take my stock, I will raise seeds and plants for you to sell. I accordingly took his stock, amounting to fifteen dollars. This, like the small mustard seed, has since filled the length and the breadth of the land.

"Thus, without foresight, or plan of my own, I worked into this business. The cut nails made me a grocer. Being supplanted in the grocery, led me to painting. The painting of pots induced me to purchase a plant to show them off. Keeping plants induced people to ask for seeds! The cutting machine, and being supplanted, I thought were sore evils, at the time; but as we afterwards see, even in this life, sore evils are blessings in disguise."

About twelve years ago, Mr. Thorburn published the history of his life, in a work entitled Forty Years Residence in America, or the Doctrine of a Particular Providence, exemplified in the Life of Grant Thorburn. In 1834, he published, Men and Manners, or a Bone to Knaw, for Trollope, Fidler, etc.; in 1845, Fifty Years Reminiscences of New York, a Flower from the Garden of Lawrie Todd."

The following extract from one of a number of communications of Mr. Thorburn, to the New York Mirror, in 1846, cannot but be interesting, for its originality of style and strong common sense:

"In taking a retrospect while I sat in my door in the cool of the (Jackson's funeral) day, I thought, were I to live my life over again, I would just manage my treaty of peace with the lasses after the same mode and form which I pursued fifty years ago; therefore, my young friends, I will just describe the process, and say unto thee, 'go thou and 
do likewise." When I emerged from the hut wherein I first drew breath (in Scotland), I looked on the daughters of men, and saw that they were fair; I resolved that as soon as I could earn one shilling sterling (twenty-two cents) per day, I would enter into copartnership for life with one of those beautiful articles. What God makes beautiful, it is for man to admire. Perceiving by statistical tables, that the God of nature sent about the same number of men and women into the world, I therefore thought it must be his law, that every man should have his mate at once, and leave consequences and provisions for the future to Him who hangs creation on His arm, and feeds her at his board. It is fifty years since I ratified that treaty of peace, love, and amity, and never, for one moment, did I repent it; nor did I ever lack a loaf in the pantry, or a dollar in my purse. If God sent another mouth, he always sent food to fill it. With regard to courtship-it is the easiest thing in the world. Love is the language of nature-the veriest fool, if he can't pronounce, can speak it with his eyes, and women are nice interpreters. When first thinking of these important affairs, I resolved never to spend an hour in the private conversation of any young woman, till I was determined on taking to myself a wife-and in the next place, never to spend an hour with any, except she was the one whom, above all others in the world, I wished to make a wife. On this principle I practised, and I prospered. There is nothing to be gained by dangling after a sensible woman for a twelve-month, talking unmeaning stuff-words without knowledge. You mistake the sex, if you expect to gain their favor by this means. While you think they are laughing at your small wit, they are smiling at your great folly. If you wish to gain the esteem of a sensible woman, (and let me tell you, they have more wit, in general, than half of the men,) you 


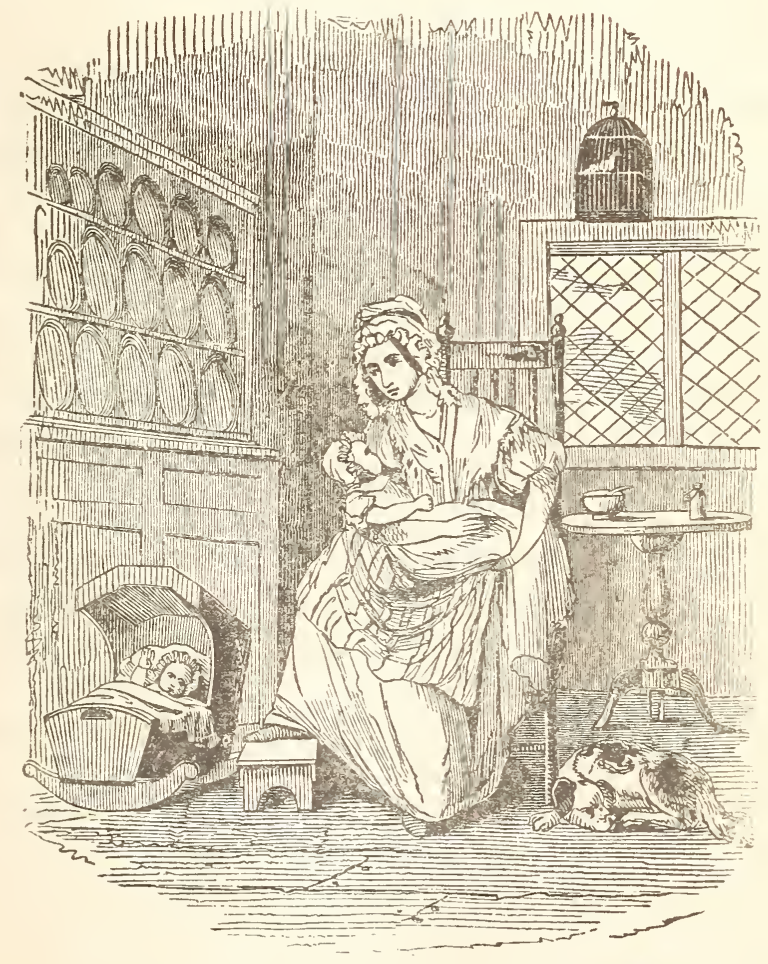

If God sent another mouth, he alway sent food to fill it. p. 18\% 

must speak to her in the words of truth and soberness. After three or four sittings, (as the portrait maker says,) tell her your intentions at once, like a man, not like a blubbering school boy; and if there is seven ounces of common sense in your carcass, she will be yours in one month; and if you behave like a man of sense while you walk together by the way, the honey-moon will never wane, but grow brighter and brighter, till you put up at the last inn by the wayside-the grave. Having now got married, devote the leisure hours to nourish and cherish your wife; leave politics, whig and tory, to the pure democracy, they will make as many presidents for you, gratis, as will serve for a life time. If your circumstances are easy, and thou art fond of outdoor amusements, let your wife be your constant companion-it is unkind, unmanly, and unpolitic to leave her moping alone, whilst thou art abroad finding thy own pleasures. If it is thy lot to earn thy bread by the sweat of thy brow, when the labor of the day is past, devote the evening to the company of thy wife; if there are no extra cares to prevent, walk together in one of the beautiful parks, or go to hear a lecture (where it is gratis) - thus you will learn something, and make a long evening seem short. If thy wife is engaged in repairing thy garments, or smoothing thy linen, then sit by the table (one candle will serve both) and read to her the news of the day, or some useful book; if children are to be cared for, stay at home and do your part; if one is fretful, take it on your knees, and sing to it, 'Auld Lang Syne;' if the other stirs in the cradle, put your foot on the rocker-this will lighten the cares of your partner, and bring a smile on the face you are wont to admire-I speak from fifty years experience."

That portion of his advice to a husband, when a wife begins to exhibit symptoms of extravagance in furniture, etc., is irresistible. Says he:

\section{4}


"Fly, as you would the plague, all temptations to purchase plate. Perhaps your wife attends a tea-water company, at the house of Mrs. Van Pelt. Mr. Van Pelt is an old established, thriving trader. On the table is a silver tea-pot, sugar-bowl, and tongs. You go to see your wife home-she looks sad-and on the way she never opens her mouth. Having got home, she takes her stand at the glass, while untying her hat. Her late pretty face is now as long as a bean pole. She looks as sober as a church-mouse-you are distressed on her account -in the most soothing manner possible, you inquire what is the matter with your dear Maria? She looks as if she had lost all her friends-for one minute she won't speak, and, perhaps, she begins to cry. Now, be cool, take it easy, and acquit thyself like a man. These tears are the grape-shot, which the ladies always carry in the fountain of their sparkling eyes-with it they mow down their opponents as fast as did the invincibles of Bonaparte on the plains of Wagram. We have wholehog, half-alligator, and half-horse men in Tennessee and Kentucky; they will stand before Colt's six-barrel revolving pistols; but there is not ten men between Plymouth rock and the shore of the Pacific that can stand the shot from a woman's eye. As I advised above, keep cool for a space, and say nothing; sit on a chair near enough to be heard; cover your face with sackcloth, whimper,'and cry a little, just by way of galvanic sympathy. As soon as she hears you sigh, her tender heart will relent, and instantly become your comforter. Now, you will hear that all this muckle adoe about na'thing was only a storm in a tea-pot-this hateful tea-pot, this sugar-bowl, and milk-pot. 'I am sure, Mr. Snodgrass, you can afford me a silver tea-pot as well as Mr. Van Pelt does to his wife,' \&c. Now, another crystal tear is rolling across her pretty eyes-don't look on them-you will be shot; for her sake, for 
your own sake, and for the sake of the next generation, don't give up the ship; draw closer your chair; commence a mild and soothing speech, sprinkled now and then with some of the elegant extracts, metaphors and epithets, with which you were wont to address your Maria, ten days before marriage. Begin the exordium as follows-"You know, my dear, that Mr. Van Pelt has been long established in a profitable and certain businesshas made a fortune, and is now on the point of retiring; whereas, we are only beginning with a small capital. I can't conduct my business without borrowing money from the banks--(bank discounts.) When I borrow $\$ 100$ from the bank, I pay $\$ 7$ every year interest. Were we to get this silver tea-pot, milk-pot, sugar-bowl, and tongs, they would cost nearly, or may be over, $\$ 300$. Now, the interest on $\$ 300$, is $\$ 21$ per annum. This would buy you a good summer and a good winter hat, and a thou sand times rather would I look on your pretty face under a handsome hat, than to see you pouring tea from a silver tea-pot, to wet the mouths of some, who might go home and laugh at what they would call our extravagance.' I believe your wife is a sensible woman, and will relent at once."

Mr. Thorburn became naturalized while Washington was President. He has married more than once, and is the father of many talented and fine grown men and women. His height is only four feet ten inches, and his weight not more than ninety-eight pounds; and yet, says the London Morning Herald, previous to his emigration to New York, he beeame an object of dread to the British government, as one of the "friends of the people." He is now in his 75th year, and in the enjoyment of good health. 


\section{WASHINGTON IRVING,}

Is a native of New York city. He was born in William street, near the old Dutch church, on the third of April, 1783. Recent writers are in error in supposing that the house is still standing. It was taken down many years ago, and upon the spot stands a large brick building. Very soon after his birth, however, his parents removed to the house opposite, No. 128 William street, next door to Samuel Guilford, Esq., who has lived upon the spot for more than seventy years. This house, occupied as a store, is still standing. His father and mother were natives of Scotland. The former kept a store in William street many years, and was a man of high character and respectability, although not of a literary turn. Mrs. Irving was a woman of fine attainments and great energy. They had five sons and one daughter. The sons received the best education that the country afforded, and were all possessed of superior talents. William, the eldest, a merchant, was an excellent classical scholar, and well versed in the modern languages. He was for many years a member of congress, from the state of New York. Peter, the second son, studied medicine, and at one time kept a drug store in Broadway, near Partition (now Fulton) street. He afterwards became editor of the Morning Chronicle, a paper established to support the election of Col. Burr. The third son, was the late Judge Irving. The fourth, was Ebenezer, a merchant and auctioneer. Washington, was the youngest. He received his education at Columbia college, and his first buddings forth, as a writer, were in a series of communications to the Morning Chronicle, under the signature of Jonathan Oldstyle. It appears that 
even his brother, the editor of the paper, did not at first know the name of his anonymous contributor; and that often, in the presence of the latter, he and others would speculate upon the subject. On one occasion, however, Washington being unable to preserve the gravity of his countenance, the secret came out. It has been stated that he manifested, in his youth, an almost melancholy disposition, but the gentleman from whom much of the above information has been elicited, and who was intimately acquainted with the subject of our sketch, never discovered any foundation for such a remark. On the contrary, says he, until threatened with consumption, he was always full of frolic, and ever ready to join in any mischief.

Mr. Irving studied law with the celebrated Josiah Ogden Hoffman, Esq., and was honorably admitted to practice. It is said that he actually opened an office in the legal quarter of the city, with the words:

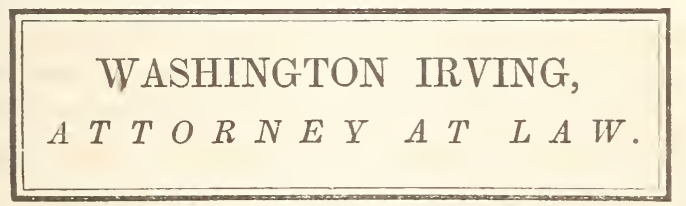

upon his door, and was once alarmed by the appearance of a client. But it appears that "an oppressive feeling of diffidence caused him-to shrink from trying the cause, and it was gladly abandoned to a brother lawyer of far less talent, but who had a more happy degree of confidence in his own forensic abilities. This diffidence, literary success has converted into an innate and unaffected modesty, that adds not a little to his agreeable qualities, and which is rare in a person possessing the high reputation he enjoys."

Of his literary career, his travels, and his mission to Spain, it is now unnecessary to dwell upon. It 
will be sufficient to say, that if "there ever was a writer whose reputation flourishes greenly in two hemispheres, who has made friends of every class of the people, who is read with as much pleasure by childhood as by age, who has attained the rare felicity of filling the hearts of all his admirers with a feeling of personal interest, who has interwoven his own name with the traditionary history or customs of three different and distinct countries, and whose fame has suffered no diminution from the time he first broke upon the literary world, till he has virtually withdrawn from it, that writer is Washington Irving!"

\section{THOMAS WARNER,}

A criminal lawyer of extensive practice in New York city. He was born at Brighton, Sussex county, England, on the fourth of April, 1803. His father, who was a miller and biscuit baker, was not able to give him more than a very limited education. By intimations from a relative of the earl of Harrington, it was expected that Thomas, when of sufficient age, would receive employment under government-but he was disappointed. His parents then strongly urged him, as an only son, to remain with them in their business; but he had higher thoughts. He had taken a strong fancy to the legal profession. He adored law books, and learned counsellors in big wigs, and silk gowns, appeared to him in dreams. He had not the remotest idea of spending his life in baking biscuits. A friend of the family sympathized with him, and evinced his sincerity by procuring him an opportunity of entering the office of Charles Pearson, Esq., the present 


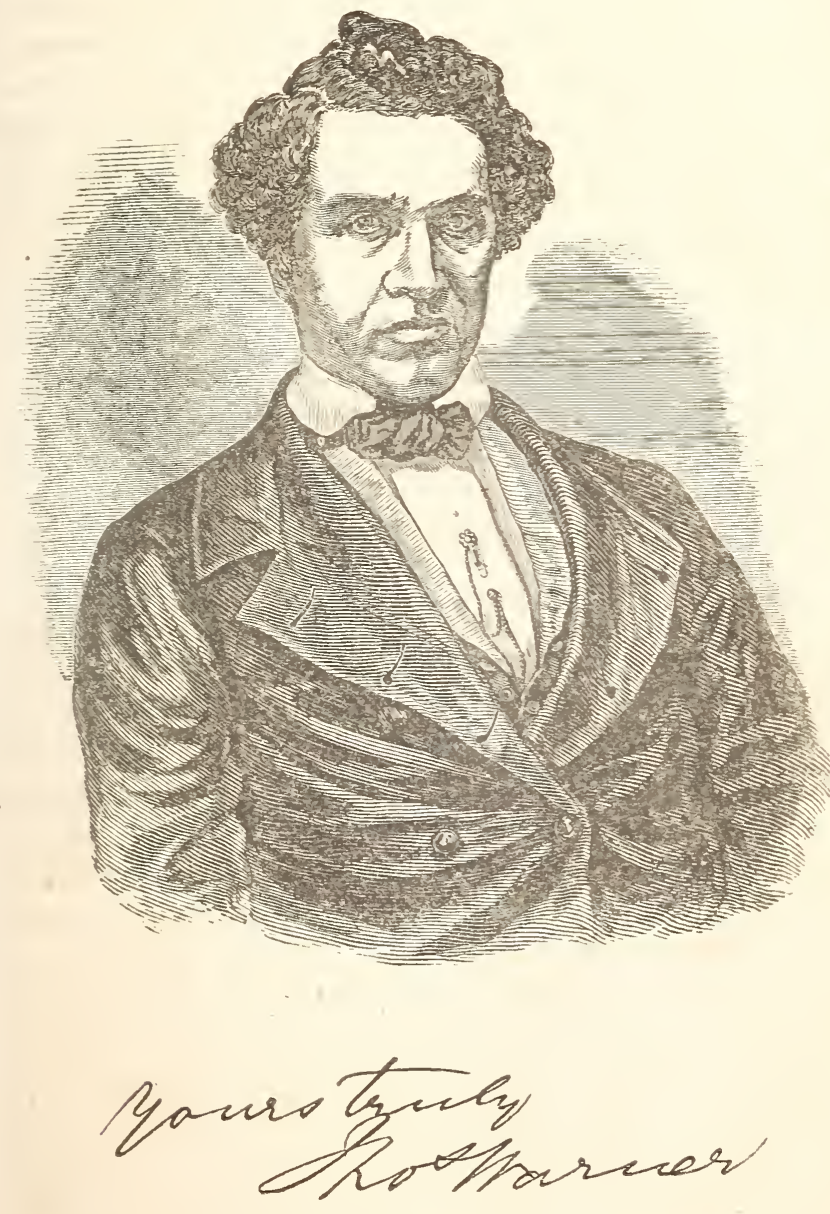



solicitor of London; but he was not permitted to embrace it, his father being inflexible, and his mother denouncing the lawyers. So the parties had now fairly joined issue. It was "Bakery versus Law." Could the result be doubtful? No: for who ever heard of the law being worsted? Thomas "snapped a judgment" against the plaintiff, and at the age of sixteen left the bakery-not like Whittington, with a cat, but-with a hundred pounds sterling, the savings of his youth, in his pocket. With this he articled himself to a nember of the bar; but, owing to inexperience in such matters, he did not make such a bargain as would enable him to demand a regular course of instruction. He had therefore to labor under serious difficulties in acquiring the requisite knowledge, and at the same time to procure a living. But he conquered difficulties by attempting them, and at the expiration of his term, he, as an attorney, entered into an extensive practice. For several years he was engaged in criminal prosecutions, under the auspices of the secretary of state for the home department, and the metropolitan police magistrates. The extent of his business may be inferred from the fact, that on one occasion, at the assizes for the court of Surrey, the records show, that he was engaged in forty out of the eighty cases on the calendar. On another occasion, he conducted the prosecution of three notorious burglars, with so much skill, that Justice Gadzdee publicly ordered him to be paid an extra fee of twenty guineas out of the county treasury. He was engaged by the home department to procure the arrest and conviction of the murderers of Mr. Richardson, on Barnstead Downs, in Surrey. Having five police officers at his disposal, he scoured the countryfor some weeks, and eventually captured two men and a woman, as the supposed culprits. The magistrate before whom they were taken, not deeming the evidence sufficiently strong, 
discharged them; but at a subsequent period, one of the men, when at the gallows for another offence, confessed that he and his companions committed the murder. Among other important cases in which Mr. Warner was engaged, was that of Major Beauclerk, a relative of the duke of St. Albans, and who under a charge of a revolting crime, cut his throat while in prison; also, that of Captain Henry Nicholls, of the British army, who was executed for a similar disgusting offence.

In $1 \prec 35$, Mr. Warner emigrated to this country; but on arriving at New York, he found that a long probationary term must precede permission to practice. After remaining three days, he tossed up a halfpenny, to decide as to whether he would stay, or return to London; and the die was cast in favor of remaining. Upon what trifles does our fate depend. Was it chance which caused the coin to fall as it did? His mind being made up, he at once declared his intention of becoming a citizen, and sought employment, in whatever shape it might offer. He was soon engaged in the office of the clerk of the common council, in preparing some old corporation records for the press. Here he remained for about three months, during which period he wrote, upon an average, a hundred and twenty folios per day, at six cents per folio. He then, for the first time in his life, directed his attention to the press, and was successfully engaged as reporter and assistant city editor for the New York Daily Advertiser, the Times, the Transcript, and other papers. In this department, his great capacity for labor, and his extensive general knowledge, rendered him a valuable coadjutor. During that time he tried his hand at speculation, but camc out a loser.

In 1838, he succeeded in forming a connection in the legal business, with A. O. Millard, Esq., with a view to admission to the American bar. In the fall of that year, in consideration of his previous studies 
in England, he was admitted to the New York court of common pleas; and in 1839, attorney and counsellor in the supreme and district courts. In 1844, he became an attorney and counsellor in the supreme court of the United States, having thus, by his indomitable energy fully proved the wisdom of his motto: " mil desperandum." The main secret of his success was-attention to business. He adopted the plan of a facetious writer, who in his advice to lawyers, says: "Put a couple of pounds of birdlime upon your office stool, and sit down upon it; get a chain round your leg, and tie yourself to your desk; nail yourself up against the wall of your office like a weasel on a barn door, or the sign of the spread eagle; and my life for yours, if you do not do business. You may get fat upon a rock, if you never quit hold of it."

It is scarcely necessary to enumerate the many important cases in which Mr. Warner has been engaged since his admission to the American bar. Nany of them are still fresh in the public mind. There was his successful defence of Christiana Cochrane, alias Gilmour (the first extraditio case under the Ashburton treaty,) who was arrested on a charge of murdering her husband, in Scotland, and who was afterwards tried there and acquitted. He has also distinguished himself as a successful advocate, in several highly important suits, involving patent rights. In conjunction with Mr. Brady, he defended William Leighton, who was tried before Judge Kent, upon a charge of having murdered his wife, at his tailor's store in Broadway, and of setting fire to the premises, to conceal the murder. After an exciting trial, of more than a week, Leighton was acquitted. This case excited unusual interest, inasmuch as the body exhibited no external or internal cause of death. The medical witnesses all differed from each other, on many important points, and so singular was the subject deemed, that the 
last American edition of Guy's Forensic Medicine, devoted several pages to the consideration of the case, and the advancement of a theory based upon it.

The rules of good taste will not permit a particular allusion to the charitable deeds of the subject of this sketch; but the destitute and the afflicted never appealed to him in vain, and the oppressed were never turned away from his office because they were too poor to pay a defender.

Should his father, who is still living on a small competence in London, ever visit New York, and see the substantial harvest which, in spite of heavy losses, and perplexing difficulties, his son has gathered around him, by the practice of the law, the worthy gentleman would instanter order a nolle prosequi, to be entered in the case of Thomas Warner, charged with absenting himself from the bakery without leave.

Mr. Warner is married, but has, we believe, no children. 


\section{OGDEN HOFFMAN.}

He is a native of Orange county, and the son of the late Hon. Josiah Ogden Hoffman, who was himself one of the most distinguished members of the New York bar, as early as the days of Alexander Hamilton, Aaron Burr, John Sloss Hobart, John Morin Scott, and contemporary with Elisha Williams, John Wells, Thomas Addis Emmet, and others, whose names have spread so much lustre on the legal profession. Surely, "there were giants in those days."

The elder Hoffman was recorder of the city of New York during the last war, and at the time of his death, was associate judge with Messrs. Jones and Oakley, on the bench of the supreme court of that city. He was a man eminently distinguished for his legal knowledge and acquirements, both as counsel and judge.

During the war, Ogden Hoffman, then between fourteen and firteen years of age, received a midshipman's warrant; and his first cruise was under the gallant Decatur, in the frigate President, when she was captured off Long Island, by a British squadron, after one of the most desperate defences on record.

The United States frigate President, one of the finest vessels of her class in the navy, sailed from this port on the 14th of January, 1815, on a cruise In going over the bar she grounded, and thumped heavily for an hour and a half. At high water she was forced over, and although Decatur wished to put back and repair, the wind blew so strong from the west that he was compelled to go to sea. An unfortunate result, as the sequel proved.

The same day he was chased by a squadron, con- 
sisting of the Majestic (razee), Endymion, Pomone, Tenedos, frigates; and Despatch, brig. The chase continued until the next day at three, when the Endymion, the headmost ship, commenced the engagement; but she was soon silenced, and would have been taken, but for the approach of her consorts-nor did she fire another gun during the action. The Pomene and Tenedos now came up and continued the engagement, which was spiritedly met by the President; but their force was so overwhelming, that longer defence would have been butchery, and Decatur reluctantly struck his flag, after a chase of two days, and an engagement, off and on, of six hours, with four vessels, either of which would have been considered his equal. In this fight he had four lieutenants and twenty men killed, and fifty-five officers and men wounded, or nearly one-fifth of his crew.

In this action, young Ogden Hoffman displayed great bravery, and was highly spoken of by his superior officers.

On his return to the United States, peace having been declared, he resigned his midshipman's warrant, and commenced the study of the law. After being admitted to the bar, his talents and eloquence soon brought him a fair practice, and he was for some time district-attorney of Orange county.

In the city of New York, his brilliant and melodious style of oratory soon placed him arnong the first pleaders at the crininal bar. He was appointed, about the year 1828, district-attorney of New York, which situation he held for four years, but was not reäppointed, in consequence of a change in his politics.

In 18:37, he was nominated by the whigs, for congress, and was elected for two consecutive sessions, by large majorities, and in both instances was ahead of the rest of his ticket-an honorable com- 
pliment from some of his political opponents. At the election of Gen. Harrison, he declined a nomination, and was by that lamented man appointed United States attorney for the southern district of New York.

Mr. Hoffman's eloquence is of a peculiarly fascinating nature. His voice is melody itself-soft, yet at the same time as clear and ringing in its tones as the loudest trumpet. He is always listened to with the deepest attention by a jury. In popular assemblages, no man is more warmly and cordially greeted and applauded. He is of the medium height, and about forty-six years of age.

\section{PRESERVED FISH.}

The grass is now growing over the mortal remains of this celebrated merchant; but his unblemished reputation, for honesty of purpose and integrity of principles, will long survive. It is said that his singular name was given to him by some sailors, who found him, a mere infant, floating on a raft at sea. At an early age he was apprenticed to a blacksmith; but, while tlowing the fire, or working at the anvil, his thoughts were far away, to the deep blue sea; and with the instinct of an "ocean child," he longed to rock once more upon the "cradle of the deep." Hence, his next situation was that of a seaman, on board of a whaling ship. Here he soon rose to the station of mate, and finally to that of commander. In this hazardous pursuit he remained until he had amassed the foundation of his fortune. He subsequently became an extensive shipping merchant, in the city of New York. 


\section{ELIJAH F. PURDY.}

Perhaps there are few individuals in the city of New York more generally and favorably known than Alderman Purdy. He is from the stock of the Westchester Purdys, one of the oldest families in our state, and one that has ever held a prominent position in that county, as is evidenced by the fact that there is seldom an election takes place, that one of the name is not elevated to some office by the suffrage of his fellow citizens. Alderman Purdy was born, it is said, at White Plains, Westchester county, and is now about forty-eight years of age, in the full vigor of manhood and intellect. After receiving a respectable English education, he was apprenticed to a carpenter, which profession he followed after he attained his majority, and by'his industry and attention to business, accumulated sufficient capital to open a country store. He was doing a good business, when his prospects were suddenly clouded, and the fruits of years of toil destroyed by the devouring flames.

This catastrophe only stimulated Mr. Purdy to renewed exertions, and he resolved to try his fortunes in New York. He removed to that city, with his family, we believe, in 1821. Here he resumed his trade for a while, and then turned carman, and drove a horse and cart for a number of years.

Alderman Purdy took up his residence in the tenth ward, and was soon recognized as an able and efficient politician, by the democratic party of that ward.

In 1831, he received an appointment in the custom house, and during his continuance in that situation, obtained a high reputation with the mercan- 


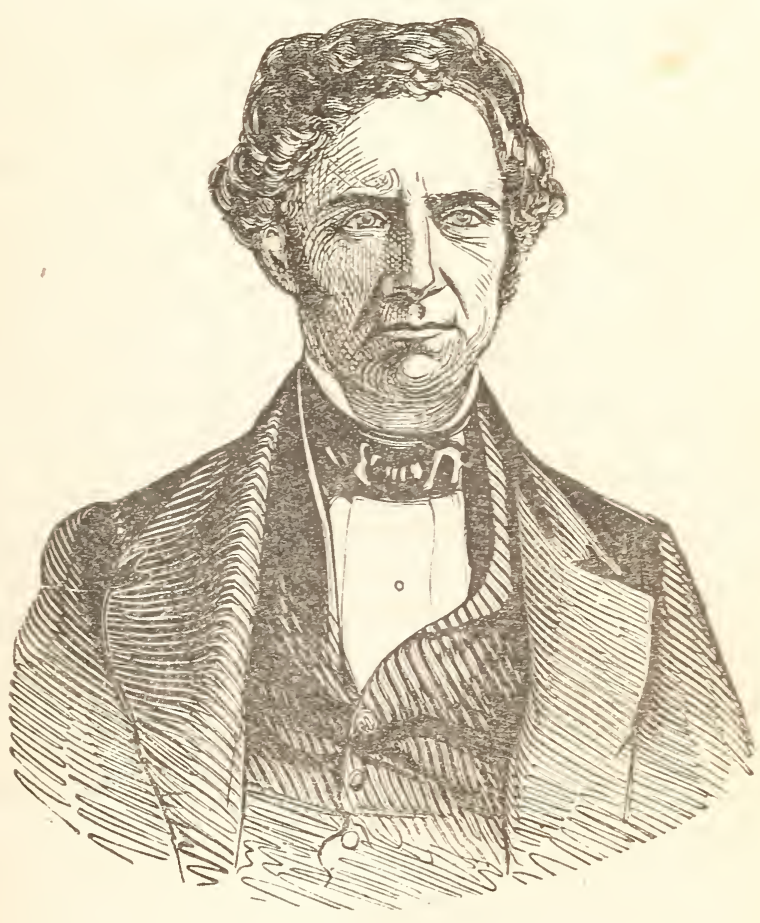

ELIJAH F. PURDY. 

tile community, for his correct business transactions and habits. In the early part of 1836, Mr. Purdy, who has always been a great stickler for the doctrine of rotation in office, resigned his situation in the custom house, and retired to private life.

In the spring of 1840 , he was elected president of the board of aldermen, which honorable station he occupied until the accession of the whig party to power, when he had leave to retire to his old seat. As a presiding officer, he was always strenuous in maintaining the dignity of the chair; and although he was not altogether au fait in matters of parliamentary usage, and the rules laid down in Jefferson's Manual, yet we believe he gave universal satisfaction, by the manner in which he presided over their deliberations, to both parties in the board.

In the winter of 1840, Alderman Purdy, by virtue of his office as president of the common council, in consequence of the severe indisposition of Mayor Varian, was called upon to officiate as mayor; and for some months he performed the duties of that arduous and responsible situation, in addition to his other multifarious duties, to the entire satisfaction of the public and the common council. 


\section{BENJAMIN STANTON.}

And when the orb of day has crown'd

With gold the western sky,

Before his dwelling he is found,

With cheerful faces by-

With little Jaughing duplicates,

Caresses will not snoil;

Oh, joy at every side awaits

The tiller of the soil!

Benjamin Stanton was born on the 15th of October, 1794, in what is now the town of Westerlo, county of Albany. His parents were English. His father was a baptist clergyman of extraordinary talents, and conceded by his compeers to have been an ornament to his profession. Benjamin was his fourth son, and having received such an education as our common schools could then afford, was brought up as a practical farmer. In 1814, he married an amiable and interesting wife, and in six days thereafter was called to the defence of his country. Such was his soldier-like appearance and patriotic ardor, that although the junior of every officer of the company, he was voluntarily tendered a commission, which he accepted, and honored by the most unflinching devotion to military discipline. After serving the term for which he was called into service, he returned to the enjoyments of the domestic circle.

In 1816, he purchased and located himself on a farm at Durham, Greene county, New York; but he followed not in the course of that class of farmers whose whole action, both mental and physical, is confined to the drudgery of manual labor. By him, science and philosophy were put into requisition, which, when added to his zeal for the promotion of every philanthropic object, made him a high. 
ly useful member of community. How truly has it been said, that the situation of the independent farmer stands among the first for honesty and virtue. It is the one to which statesmen and warriors have retired, to find in the contemplation of the works of nature, that serenity which more conspicuous situations could not impart. It is an agreeable life, and dependent upon no one's favor, except His, who has said, that "while the world endureth, seed time and harvest, summer and winter, shall not cease."

In 1835, Mr. Stanton sold his estate in Greene county; and in a tour of observation, through seven of the south-western states, became afflicted with the prevailing disease of that section, and narrowly escaped with his life. In 1836, he purchased a farm at Westerlo, adjoining the parental homestead, where he still resides, surrounded by a small, but happy family, and in the honest and faithful discharge of his duty as a practical and scientific farmer, which affords ample scope for the exercise of his benevolent disposition.

In 1843 , he was elected president of the Westerlo Temperance society, the principles of which glorious cause, he has for more than twenty years, both by precept and example, advocated with all his zeal and energy.

In 1846 , he was elected a delegate to the convention for revising the constitution of the state. That he was not a speaking member of that body, is true; but it by no means follows that loquacity and industry always go together. It is sufficient to say, that while there, he acquitted himself to the satisfaction of his constituents; and now that he has retired to private life, we find him still ever ready to point out and lead in the path of virtue. 


\section{MRS. EMILY JUDSON,}

The subject of this sketch, now with her husband, Doctor Judson, in a remote part of the globe, assisting him in the glorious field of missionary labor, is by no means a stranger to the public. Her numerous contributions to the press, under the assumed name of Fanny Forrester, have been read with delight by many an eye, now moistened with tears at her absence. Previous to her departure, she was a highly esteemed member of the Bleecker street baptist church, at Utica.

"Born and reared in humble life, she aspired to intellectual acquisitions which could be reached only by the most devoted personal exertions, and these she used with distinguished success. Of these exertions we have learned incidents which may at some time be communicated, alike honorable to herself personally, and encouraging to others whom Divine providence may have placed in similar circumstances. Possessing rare qualities as a writer, and being a consistent follower of Christ, she made her first attempts in works of a religious character. Of these, some were published in Utica, others in New York, and not less than four have been published, at different times, by the American Baptist Publication society, in Philadelphia. These works, however, were published without her name, and the world knew not that Emily Chubbuck wrote them. Of ready apprehension, and cheerful spirits, she notices every thing pertaining to her scenes, whether real or imaginary, at a glance, and goes dashing, bounding along, wherever she lists, always making salient the points of chief interest, and bearing her readers with her, and holding them, as if by a spell. Possessing such qualities, it is not 


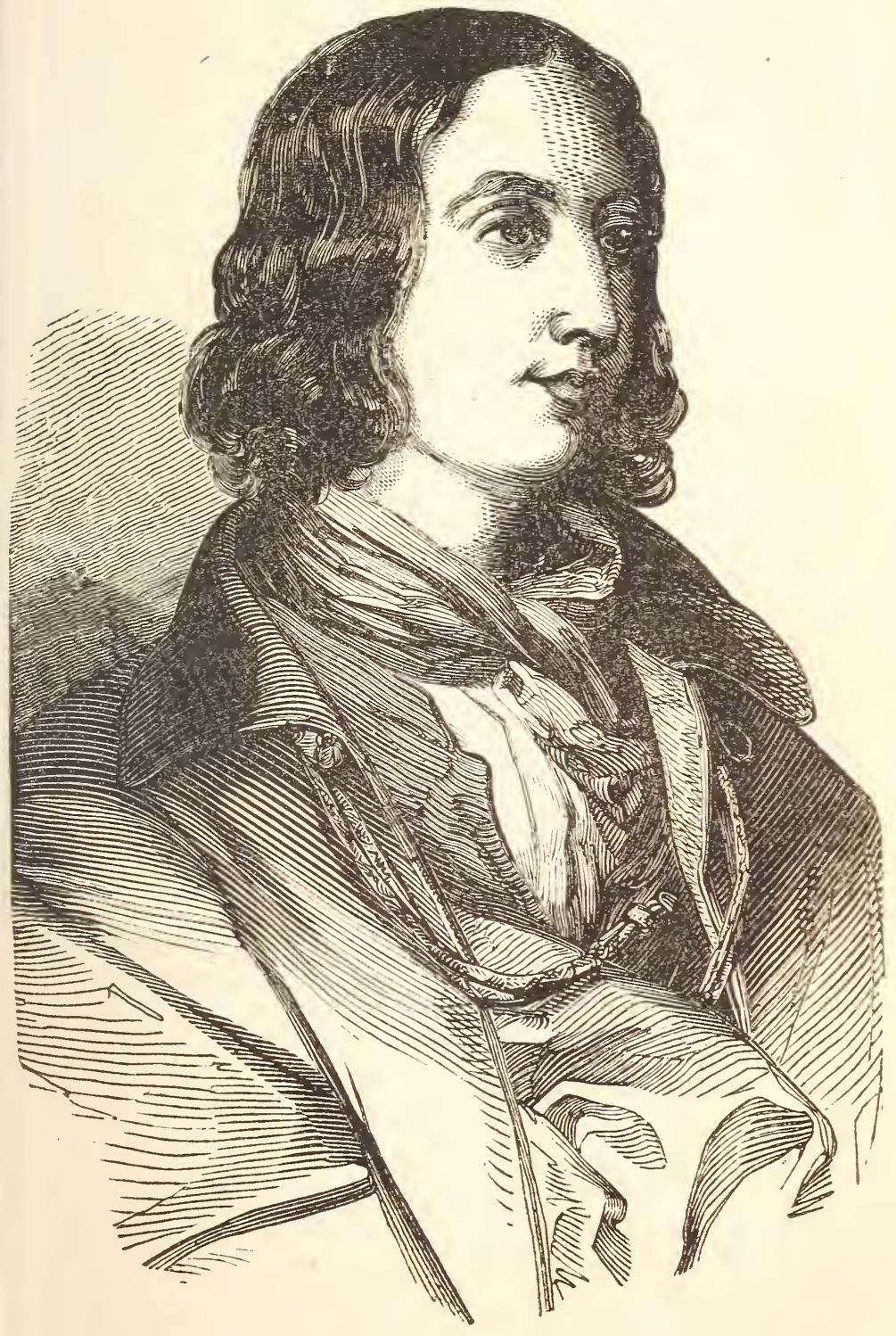

MRS. EMILY JUDSON. 

strange that her magazine articles very soon attracted attention, and created a demand for new contributions, which could be met only by intense devotion to this department of intellectual labor. In addition to this, her pieces were written under a necessity, which needs but to be named to secure for her, instantly, a favorable consideration. An aged father and mother, descending the vale of life, in circumstances of dependence, have required a profitable use of her gifted pen."

The following account of her marriage appeared in the Utica Observer:

It is a solemn and impressive sight, when two step out from the circle of friends, and, before God and men, promise to live for each other; but it is infinitely more so, when the two, in wedding each other, bind themselves to the cause of God. Such a scene, pure and holy as were the hearts plighted to each other, was witnessed in the neat cottage where dwell the parents of Fanny Forrester. The night was beautiful, and the very heavens seemed to smile approvingly upon the dedication, for such, indeed, it was, on the part of one. In the little parlor were collected a group, each face expressive of the solemn object which had called him there. The silence was broken by the entrance of the venerable and venerated Dr. Kendrick. Then came the modern apostle to the Gentile nations of Asia, bearing upon his arm a bright star from the galaxy of female genius. In the train were the friends of the bride. A moment's pause, while all were standing, and then commenced the holy ceremony. The groom, with erect figure and unsprinkled locks, betokened the vigor of manhood, while his beaming countenance portrayed the deep emotions of his heart. The bride, adorned in simple white, raised her dark eyes to the man of God, while the response of her warm heart, speaking in her eager gaze, was the finest illustration of her well chosen 
motto: 'Henceforth I pledge myself to holier purposes.' The sister and cousin, on either side, in the same simple garb, while upon their right stood two figures in the decline of life, whose emotions were plainly told in the silent tear that fell unchecked, and the calm resignation written upon their brows. The all-sustaining grace of God was in their hearts, and they could bear even this for him. Never before was I so impressed with the presence of our blessed Savior at a wedding. There was no evident affliction to call forth the melting sympathies of our natures, but with wonder and admiration did we behold in this sundering act a proof that there was a tender link between their hearts and the throne of God, which will never be severed. India's tropic clime cannot impair it, and when life's toils are over, it will sweetly draw them to the rest that remaineth."

How different is the destiny of Emily Chubbuck from that of Aurore Dupin, who, also under an assumed name, that of George Sand, wrote for the bread of herself and family. But, says Mary Howitt, to understand the works of George Sand, and to fully appreciate the deep lessons which they teach, it is necessary that the reader should know something of her history.

The married name of George Sand, is Madame Dudevant-her maiden name is Aurore Dupin. Royal blood flows in her veins; for her grandfather, by the mother's side, was the celebrated Marechal Saxe, the son of Augustus II., of Poland. Her father, M. Dupin, was a soldier, one of the aides-decamp of Marshal Murat, and died on the field of battle, leaving his child, Aurore, an orphan, at an early age. She inherited a considerable fortune, and being left under the care of her grandmother, who exercised a little restraint over her, she began early to develope that independence of character, and decided intellectual bias, which were destined 
to exercise so important an influence over her future history. She was brought up in a fine old country house, in the province of Berri, the wild and beautiful scenery of which she afterwards depicted with such marvellous effect, in her numerous works.

At the age of seventeen, Aurore Dupin was, by her friends, provided with a husband, and handed over to a M. Dudevant, with whom a mariage de convenance, as it is commonly called in France, was concluded. These mariages de convenance are the custom among the higher classes throughout France -half their marriages being mere business transactions between families. They proceed upon the supposition that woman is simply an article of barter; and while the fortune and estate of the contracting parties are carefully enough estimated, such things as heart and soul have little or no con sideration in the matter. The young woman i handed over to the husband selected for her, with her goods and chattels, of which she is regarded as but a part-she expecting protection, and he requiring absolute obedience. Aurore Dupin was young and beautiful-M. Dudevant was old and ill-favored. During some part of his life he had been a soldier, and, like most old soldiers, he enforced stern discipline in his household. Servants, dogs, and horses, trembled at the sound of his voice. He was dull and prosy, emotionless, but impatient of contradiction, fond of money and personal comfort, ignorant, and without sympathy for his kind, and though just, according to the letter of the law, he was arbitrary and tyrannic as a despot.

To such a man, was thus united for life, by an arrangement in which she had no part, a young being, warm, affectionate, high-spirited, and full of sympathy; endowed with a great heart and soul, and with the very highest capacities for happiness. There could be no sympathy or love between such 
natures-and there was none. The living body, bound side by side to a corpse, could scarcely present a more revolting picture. The soul of the woman must have been weighed down by a perpetual load of misery. Where the wife sought affection, she found indifference; where she craved sympathy, she met with contempt. She could be neither soul-mate nor help-mate to such a man.

Eight years did this pair live together, during which time Madame Dudevant became the mother of two lovely children, Solange and Maurice, the society of whom formed her chief solace in her misery. She sought occupation also in the relief of the poor of her neighborhood, by whom she was regarded as a general benefactress. She supplied those who needed them, with food, clothing, and medicines. But this could not relieve the tortures of her own heart; and the crisis of her fate had now arrived. There are limits beyond which nature refuses to be violated. In individuals, as in nations, there is always a point of rebellion and revolt. At the very same time that the people of $\mathrm{Pa}$ ris were rising in rebellion against the despotism of their rulers, did this long-suffering woman, in like manner, after long strugglings, rise up against the despotism of her husband. She revolted, and quitted her married home, in the year 1830, leaving every thing behind but her children, whom M. Dudevant would not allow her to take with her, unless on condition of surrendering to him her whole fortune, some 500,000 francs. To preserve her independence, and her children, she gave up this money to him. She went straight to Paris, there to commence writing for her own and her children's bread, under the assumed name of George Sand.

We do not say that her early works are fit for indiscriminate reading by youth. To understand them, one must have endured sharp and bitter experience of the world. To sympathize with them 
thoroughly, one must have suffered in the tenderest part of our nature--in the affections. There is, in her early works, a piteous and prolonged wail of agony - a breathed anguish of the tortured hearta desperate struggling of a wronged and outraged nature-a succession of pictures of social misery and torment, which we look upon as a kind of mental aliment not to be placed before the young and pure in heart, who have never known such sorrows as the writer herself has endured. But when we recognize in these writings, as the thinking and observant mind cannot fail to do, the indignant protest of a noble woman against a false and vicious system-a woman who has suffered, in her own person, the worst of what she depicts-is it not right, we ask, that such things should be known, were it only as a first step towards a remedy, and as a means of awakening society from the indifference with which it has heretofore been accustorned to regard such monstrous wrong and injustice?

It is a gross mistake to confound George Sand with the depraved writers of the Balzac, Janin and Sue school-for she never makes vice beautifulnever rewards crime-never strews roses over corruption-virtue is by her always surrounded with the glory of art, and the blessedness of well-doing is represented as the highest aim and reward of life. 


\section{BENJAMIN FRANKLIN BUTLER.}

It has been truly said of this distinguished man, that his life has flowed on, like an even and unruffled stream, gathering its great depth of volume from a thousand springs, unseen to the public eye; and though scarcely perhaps noticed by the stranger, whose admiration is rather attracted by the more picturesque wildness of the mountain torrent, yet diffusing a daily beneficent utility to the dwellers upon its tranquil borders, and an object of a far higher admiration to the more judicious eye, that can better appreciate true excellence. Having risen from a humble beginning, by the great but zealous exercise of those qualities, which, similarly applied, can never fail to command a similar success-industry, self-cultivation, integrity and purity of lifehis career presents one of those pictures best illustrative of the spirit of our institutions, and best calculated for a useful example, and encouragement to others.

Mr. Butler was born at Kinderhook, December 14, 1795. His father, Medad Butler, was born in Branford, Connecticut. The grandfather of the latter, Jonathan Butler, was one of the two brothers, Irish adventurers, who came to Connecticut about 1710. He married a descendant of the original puritan settlers of that colony. His son, Ezekiel, married Mabel Jones, a lineal descendant of Col. John Jones, and Catharine, a sister of Oliver Cromwell. Catharine was a second wife, and Mabel, the ancestress, of the subject of our sketch, was descended from a son by the first wife. Catharine had no children. This Col. Jones was one of the renegade judges, and, after the restoration, suffered the penalty for that act, "whose stern glory shall immor- 
talize the names of all who participated in it, by being beheaded for high treason. His father came to Connecticut, and many of his descendants are to be found in different parts of the United States.

From the earliest age, Benjamin was always fond of books, reading all he could find, with great avidity. Among them were the works of Benjamin Franklin, to which book, more than to any other, he ascribes the formation of his character. $\mathrm{He}$ commenced learning Latin at the age of seven, and continued at school until his fifteenth year.

In 1811, Mr. Van Buren took him into his office, as a law student, at Hudson.

In 1817 , he was admitted to the bar, as an attorney of the supreme court, and solicitor in chancery. Mr. Van Buren, then attorney-general of the state, shortly afterwards admitted him into partnership in his professional business at Albany.

In Nov., 1824, he was appointed, together with two other distinguished lawyers, to the arduous charge of a revision and codification of all the statutes of the state of New York. He was, however, connected with this revision for a much longer term than his associates, being one of the first appointed commissioners, and continuing in the work to its termination.

In $1829, \mathrm{Mr}$. Butler was appointed a regent of the university, but he resigned in 1×32. In November, 18:33, at the earnest request of President Jackson, he accepted the office of attorney-general of the United States, although he had declined all previous offers to induce him to go to Washington. $\mathrm{He}$ served one year during Mr. Van Buren's term, when he resigned.

In addition to his professional labors, he has always been an advocate of the great cause of moral and religious philanthropy. He has been an arduous friend of the temperance cause; and ever since 1817, he has been a member of the Presbyterian 27 
church. His wife, whom he married in 1818, is a sister of the gallant Lieut. Allen, of the navy, who was killed in a boat attack of a piratical schooner, in 1832 .

Although at much inconvenience to himself, $\mathrm{Mr}$. Butler was never known to refuse to lend his aid towards the advancement of any good object. He very recently delivered an interesting lecture in Albany, before the Young Men's Association of that city, in which he impressed upon the minds of his hearers, the priceless value of integrity and perseverance.

\section{STEPHEN ALLEN,}

Affords another instance of what may be accomplished without money, without family connexions or friends. Mr. Allen commenced life, it is said, as a poor sailor boy. He was afterwards a sail maker, and finally kept one of the largest establishments of that kind. By his punctuality and integrity, he amassed a large fortune. When the tempest raged in its fury, and he almost sunk under the hardships of his situation, how the heart of that poor sailor boy would have bounded for joy, could he have foreseen that he would at a future period, become mayor the city of New York, for three successive years, and afterwards fill other high offices of honor and trust! 



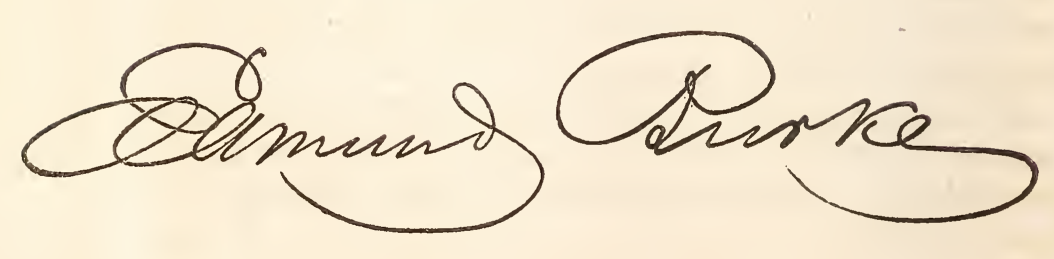




\section{EDMUND BURKE.}

The career of few men, says the Democratic Review, affords a better illustration of the fostering tendency of republican institutions, than is to be drawn from that of the present commissioner of patents.

The family of this gentleman is of Irish origin. They originally resided in the town of Westminster, Vermont, situated in the beautiful valley of the Connecticut, where his father cultivated a farm, and where the subject of this sketch was born, on the 23d of January, 1809. The circumstances of the parent, like those of most middling farmers of New England, were such as to compel him to keep the son at agricultural toil, until sixteen years of age, with the exception of the time prior to his fifteenth year, devoted to the exercises of the ordinary country free school of those days. Fortunately, the talents of the parent were of no common order, and he strictly fulfilled the duty of training the mind of his son, which at sixteen, was sufficiently developed and well informed, for commencing the study of the law, in the office of the Hon. W. E. Bradley, (of Westminster, Vermont,) who has so long ranked as one of the most enlightened republicans and eminent jurists of New England.

In the autumn of 1829 , before the close of his twenty-first year, Mr. Burke, after passing the usual examination, was admitted to the bar. In the following spring, he commenced the practice of this profession in the wild northern region of the state of New Hampshire, where, in three years, his experience with men and things, not only taught him much of human nature, but matured his intellect.

In 1833 Mr. Burke removed to Claremont, Sulli- 
van county, New Hampshire, and there established the New Hampshire Argus, which under his management, immediately took rank as one of the first democratic papers in New England. The success of the Argus soon caused its removal to Newport, the shire town of the county, where it was united with the New Hampshire Spectator; and under the sole editorial direction of Mr. Burke, the joint establishment took the name of the New Hampshire Argus and Spectator. Such was his success in this theatre, that, in $1 \backsim 37$, though personally a stranger to the present president of the United States, (then speaker of the house of representatives,) and Senator Grundy, he received overtures from these gentlemen, on behalf of the leading democratic politicians of Tennessee, to remove to Nashville, and assume the editorial charge of the Nashville Union. Mr. Burke, on reflection, having determined to accept this invitation, published his valedictory, which immediately brought forth so strong a remonstrance from his political friends at home, that he gave up the intention of removing to Tennessee.

At the next congressional canvass, he was nominated, and triumphantly elected to the house of representatives of the United States; and took his seat on the $2 \mathrm{~d}$ of December, 1839, at the opening of the 26th congress.

He soon obtained rank in this new field, as a man of a high order of intellect, extensive acquirements, untiring industry, and uncompromising political integrity. The famous debate of 1840 , on the subtreasury bill, may be said to have first made the democratic party, out of New England, acquainted with the intellectual powers of Edmund Burke, and to mark him as one of the rising men of the country.

In 1842 he had occasion to approach the tariff question, in an argument supported, as usual, with results of his statistical researches, in connection with the science of political economy. This effort, 
which won him great credit with his political friends in the house, was extensively republished in democratic journals. During the discussion of the Rhode Island difficulty, after close investigation into the questions at issue, Mr. Burke became a zealous advocate of the party attached to Thomas W. Dorr.

The six years of his congressional life. were devoted to intense labor, which has left in the public archives, honorable and abundant evidence of his indefatigable industry and expanded intellect.

- Upon the advent of the present administration, without personal solicitation on his part, the president called Mr. Burke to the responsible position of commissioner of patents; which trust he now fills, with so much credit to himself, and satisfaction to the scientific and ingenious of the country, with whom his official duties bring him constantly into contact.

Mr. Burke is the author of the well known series of essays on the protective system, published in the Union under the signature of "Bundelcund."

A periodical of high standing, says of Mr. Burke, "He possesses one of the best informed minds in the country. In the midst of all his political labors and private business, which has never been neglected, he has found time to devote himself to the acquirement of much scientific and literary information, and there are few, very few private libraries in New England, which will compare with his in size or in usefulness. His characteristics are energy of purpose, untiring industry, uncompromising hostility to everything aristocratic, or un-American; devotion to his political principles, equal to that of a Mahometan to his prophet; attachment, which hardly knows a bound, to his friends; frankness, which never permits him to conceal his honest opinions on any subject. In his bearing and manners, he is urbane and gentlemanly to all who have occasion to come in contact with hirn in public or private 'ife." 


\section{ROBERT H. MORRIS,}

Was born in the city of New York. His father, Robert Morris, soon afterwards removed to Claverack, Columbia county, near the city of Hudson, where the subject of this memoir received his education. Being strongly attached to the law, he studied with the Hon. J. D. Monell, and subsequently with the Hon. J. N. Edwards. So close was his application to study, that he attained such proficiency as entitled him to the highest praise of the examiners of the law, and he was admitted to the bar before he had attained the age of twenty-one. He commenced the practice of his profession at Johnstown, Columbia county, where he was an early and ardent advocate of democratic principles. While a resident of Livingston, he received many proofs of great personal popularity.

Early in his professional career he became distinguished as an advocate. In 1829, having previously been admitted to the degree of counsellor at law, he returned to the place of his birth, the city of New York, and pursued the practice of his profession with extraordinary success-with his characteristic energy and popular manners he also engaged in politics. He was soon recognized as one of the leading members of his party, which sent him to the legislature in 1833, and he was re-elected in 1834. At the latter session, during the celebrated struggle for a recharter of the United States Bank, he was chairman of the committee on banks, and as such, held the most important position in the assembly.

In $1838 \mathrm{Mr}$. Morris was appointed recorder of the city of New York, which office he held for about three years. During the period he remained in 
office, he discharged his duties with great promptness and general satisfaction. In 1840, (a period of great political excitement,) he, in conjunction with Mayor Varian, seized the celebrated Glentworth papers. For this he was removed by the governor and senate-the reason given for so doing, was, that he acted illegally. Whether the removal was right or wrong, others must decide.

At the ensuing election for mayor, Mr. Morris was nominated by the party to which he belonged, and elected by a heavy majority. This was to him, undoubtedly, a great triumph, showing that, at any rate, he was sustained in his views by the people of his native city.

At the next election for the same office, his majority was still greater. He was also elected a third time, on which occasion he stated his determination 'not again to be a candidate.

In May, Mr. Morris was appointed postmaster of the city of New York by President Polk, and notwithstanding he held this honorable and important office, the citizens of the city of New York, in the spring of 1846, elected him one of the delegates to amend the constitution of the state.

It has been truly observed that Mr. Morris's great personal popularity is much owing to his pleasing address. His manner is the same when associating with the elevated, as with the most humble; and towards both, he acts with that courtesy that accompanies a just appreciation of the feelings and rights of others, with a proper sense of what is due to himself. 


\section{STEPHEN C. JOHNSON.}

The ancestors of Senator Johnson, on his father's side, were of Irish extraction; and his mother's, of English descent. His paternal grandfather had the reputation of being one of the most athletic men in the town where he resided, having no superior in the county. Solomon Johnson, one of his sons, was likewise a man of extraordinary powerful frame. For several previous generations, the male members of the family were also distinguished for height, and great bodily strength. But although in those early and troublous times in the Emerald isle, when

The green of her valleys was crimsoned with blood,

and when might was too frequently mistaken for right, personal prowess was a valuable gift, the senator is fully aware that in the battle of life, in these days, when intellects clash, instead of steel, something more is necessary than muscle, bone and sinew. He is one of those who fully subscribe to the sentiment of the poet.

Were I so tall to reach the pole,

Or grasp the ocean with a span,

I must be measured by my soul,

The mind's the measure of the man.

The above named Solomon enlisted as a private soldier, in the war of the revolution; and, after exerting himself usefully for some years in the cause of his adopted country, he died in the service. His brother, Jotham Johnson, the father of the senator, was too young to enter the army until near the close of the war; and, from the need in which the family stood of his labor, although his heart was in 
the battle field, he could not take any part in the glorious struggle for independence. He married, and became a farmer, which business he has always followed unremittingly, and pretty successfully. He is still living, and has the reputation of being one of the most industrious men in the county where he resides. He is now in his eightieth year, and his health remains good. $\mathrm{He}$ is, too, one of those fortunate men who have never known a sick day:

A hardy, sunburnt man is he,

A hardy, sunburnt man;

No sturdier man you 'll ever see, Though all the world you scan.

In summer's heat, in winter's cold, You 'll find him at his toil-

Oh, far above the knight of old, Is the tiller of the soil.

The maternal grandfather of the senator was Stephen Crosby, a captain in the revolutionary war, and who died at the evacuation of New York by the British. He left a widow and a large family of children. The sons reside in Connecticut, and have, it is said, always been democrats, while it is presumed the daughters are all whigs. Hannah Crosby, the mother of our subject, was a woman of refined taste, elevated morals, and great strength of character. Few women ever possessed finer moral perceptions. She had a family of nine children, who all lived to be men and women; and it has been said that if any of them possessed talent above mediocrity, it must have been derived from her. She died about five years ago, in the seventy-fifth year of her age. How truly has it been said, that the influence of a mother touches all the deep wellsprings of action, that are felt alike in the smallest circle and in the largest empire. And hence, that appropriate adage: "They who rock the cradle, rule the world." The traces of a mother's influ- 
ence upon the young mind, the thoughts that she causes to glow and burn in that young soul, shall, one day, light up a world of emotion and energy in the bosom of others; and those in their turn, shall rouse, and stimulate, and strengthen others to acts of noble daring, until her single influence, like the power that moves the first wave, and this, in its turn, a second, and third, and the last, shall reach to the utmost boundary of time.

Stephen C. Johnson, the subject of this sketch, was born in the town of Thompson, Windham county, Ct. At a very early age he was fond of reading and meditation, and from infancy his heart had worshipped the beautiful, wheresoever found. Like others of a similar turn, he would hang enraptured "over tiny caves, lined with green and golden moss, and spend hours of exquisite felicity in sailing his little fleet, of tulip leaves, upon a clear, pebbly brook, and would peer into the colored cups and bells of the flowers, in a perfect ecstacy of delight."

As he grew older, he was one of those who would steal out, on a stormy night, to watch the wild rocking of the pines against the lowering sky; his heart swelling to the grand and sublime; or who walk in the calm summer's evening, alone and undisturbed, while the pale star of evening shines in tears, his eye piercing into the blue depths of the awful heavens, endeavoring to follow the dread idea of the Almighty to his throne.

Before the age of twelve he had read a great number of miscellaneous works, embracing a regular course of history, and the most vivid impressions were made at that period. In the common school, where he remained until the age of sixteen, it is said he had no superior, and but one equal, whose name was Aaron N. Skinner, now a resident of New Haven, Connecticut. These two stoutly contested for the head of the class. 
On the 6th of January, 1831, Mr. Johnson was married to Miss Mary Ann Swift, daughter of Sam'l Swift, Esq. He came to Delhi, Delaware county, New York, in November, 1826, poor, and having no friends, except a brother, Noadiah Johnson, who died while a mernber of the New York senate, in the spring of 1839. With him Stephen commenced the study of law, and finished with Mr. Amasa J. Parker.

In the July term of 1830 , he was admitted to the New York supreme court; and the poor, friendless young man, who twenty years ago came into that county, having no dependence but his industrious habits and determined perseverance, is now a senator from the third senate district.

\section{ABRAHAM GRIDLEY.}

Senator Gridley is the second son of Elisha Grid ley, and a native of the old, rich town of Farming. ton, Hartford county, Connecticut. $\mathrm{He}$ is a descendant of an English gentleman, who emigrated to this country during the reign of Oliver Cromwell, and who, several years previous to his migration, held the appointment of brigadier-general. He was a man of wealth, and one of an association of eighty-four, who purchased the above town, then twelve by eighteen miles, at the time of the first settlement of what was then termed the Hartford colony. Most of the said association first settled at Plymouth and Boston, about the middle of the seventeenth century.

Abraham, the senator, is of the sixth generation. He was born upon a remnant of the old family domain, on the third of September, 1793. His fa- 
ther's motner was first cousin to the elder John Adams. The maiden name of Abraham's mother was Hopkins. She was also a descendant of the pilgrims. His father served as a volunteer in the revolutionary war, and was engaged in several battles. After the termination of hostilities, he spent several years in teaching and traveling. He married at the age of thirty-one; and, in 1799, removed to the town of Paris, Oneida county, New York, where he resolved to spend the remainder of his days, as a practical farmer. Six years afterward, however, he again removed, to the town of Vernon, a short distance east of the Oneida castle, on the great western turnpike. That portion of the country was then comparatively new, and but sparsely settled by the whites, more than nine-tenths of whom lived in $\log$ cabins. The then wild and uncivilized Oneidas and Onondagas, and the half-civilized Stockbridge tribes, far outnumbered the white population in the vicinity; and when the Indians indulged, as they constantly did, in their domestic revels, they were a terror to the settlers on every side.

Abraham, being then a lad of about eleven years of age, by mixing with the different tribes, soon acquired a correct knowledge of their language, which gained him the good will of many of the red men. About this time he entered a store, as clerk, where he remained for two years. While there, he became an especial favorite of the Oneidas, even of the chief, and the head men of the tribe. They gave the young pale face credit for speaking their language, better than most whites who had endeavored to learn it. Like other youths, however, he was often engaged in playing tricks upon his red friends, when they were drurk; and on several of these occasions he was indebted to his speed, or to concealment, to avoid the drawn knife. In such cases, when his life was threatened in cold blood, 
he found it necessary, after the first gust of passion had subsided, to make peace, and to bury the hatchet, on the best terms he could. This he generally accomplished by means of a small present, and an earnest expression of sorrow.

In the spring of 1811, he procured a situation as clerk, in the lovely and rural village of Auburn, then containing between two and three hundred inhabitants, and where he has ever since resided.

On the 6th of September, 1815, he married Miss Sarah Edwards, a daughter of Capt. Isaac Goodrich, then late of Glastonbury, Connecticut. Her mother was one of the celebrated Edwards family, of Connecticut.

In September, 1814, he had commenced business as a merchant, on his own account; but the great commercial revulsion which shortly followed the unexampled profits with which the first importations were attended, and by which hundreds of opulent merchants were ruined, included Mr. Gridley in the general wreck. When this sudden change in the price of foreign fabrics took place, he had a large stock of war goods on hand. Bankruptcy was, therefore, inevitable, and not being able to effect a compromise with all his creditors, he remained insolvent until 1828, when, from the avails of his office, as Cayuga county clerk, he satisfied the last demand; and thus, without availing himself of any legal protection, which he had firmly resolved never to do, he received from his creditors a full discharge of their claims. Would that thousands of others, who have recovered from their misfortunes, and who are now rolling in wealth, would follow his example! Are there no professors of religion, who suffer themselves to be deluded by the idea, that a legal absolution from a debt is also a moral one, and that a bankrupt's certificate is a good set-off to the passage which glows upon the page of holy writ: "Owe no man any thing." 
Having previously progressed through most of the grades of military rank, to that of general of the seventh brigade of New York infantry, this latter office, in April, 1829, he resigned.

In 1840, Gov. Seward conferred upon him the office of clerk in the Auburn prison, which he retained until July, 1844. $\mathrm{He}_{\text {g }}$ is now a senator from the seventh senatorial district, to which honorable station he was nominated without any knowledge or solicitation on his part, either directly or indirectly.

In 18:0, Mr. Gridley became a member of St. Peter's church, in Auburn, and he has almost ever since been one of the vestry. He has had, also, many other offices of honor and trust, and, to a most gratifying extent, he enjoys the confidence and esteem of his neighbors. But that one blessing, if it can be so called, and which is generally deemed paramount to all others, wealth, he has never enjoy. ed. Yet he has never suffered for any of the comforts, or even luxuries of life, having enjoyed that state so desired by the prophet, "neither poverty nor riches." To him it has always been a great luxury to do all the good in his power, and, so far as his, means would permit, to relieve the real wants, and to alleviate the misery of those around him. And to this, perhaps, may be attributed the absence of that wealth which is by so many worshipped. But the time will come, when one good action shall be of more value than mountains of gold, and when all the diamonds in the world will be outweighed by a kind word. How enviable is the portion of such a man, compared with him who amasses riches at the expense of honor and fair dealing, and regardless of the tears of the orphan or the cries of the widow, heaps up dollars to canker in his soul, and wherewith to curse his offspring.

Mr. Gridley has not been a careless observer of the dealings of Providence with such men, and having, during his whole life, enjoyed uninterrupted 
health, that greatest of all earthly blessings, next to a quiet conscience, he has abundant reason to be thankful.

He is not one of those who, regardless of the severe penalty of "pride, envy, gout, dyspepsia, and a thousand imaginary and artificial wants, aspire after elevated station, and the accumulation of riches, although at the expense of trampling under foot every social duty, every moral principle, and even at the risk of endangering life itself. When has ill-gotten gain descended to the third generation? But to the just man, how cheering are the words of the psalmist: "I have been young, and now am old; yet have I not seen the righteous forsaken, nor his seed begging bread."

Mr. Gridley's father, who, during the latter portion of his life, resided at Sennett, three miles from Auburn, died on the 30 th of December, 1843, in the eighty-fourth year of his age; having through his long life, maintained an honorable independence and an unblemished reputation. He was never engaged in a law suit, and lived in peace with all men. His aged widow still survives. She is now in her eighty-fourth year.

The winds breathe low-the withering leaf

Scarce whispers from the tree;

So gently flows the parting breath,

When good men cease to be. 


\section{MRS. EMMA WILLARD.}

The name of this distinguished teacher and authoress will cause many a fair cheek to glow, and many a heart to throb at the recollection of schooldays, as

In their green, glowing beauty They move before our gaze,

Those gentle, pleasant memories

Of bygone, happy days.

$\mathrm{O}$ ! what a thing it is to be young. How easy the load of life sits upon one; how insignificant are its cares to its enjoyments; "every moment has its flitting dream; every hour its teeming pleasure, if we choose to seek it; every flower, be it bitter or sweet, be it inodorous or be it perfumed, has its nectary full of honeyed drops, ripe for the lip that will vouchsafe to press it."

As appears from a brief notice of her some years ago, in the "Connecticut Poets," Mrs. Willard is the daughter of the late Samuel Hart, of Berlin, where she was born in February, 1787. Her father was descended, on the maternal side, from Thomas Hooker, the first minister of Hartford, who is regarded as the founder of the state of Connecticut, he having led the colony across the wilderness from the vicinity of Boston. Her paternal ancestor was Stephen Hart, a deacon of Mr. Hooker's church, and his companion across the wilderness.

The subject of our sketch has been long and favorably known to the public, by her devotion to the cause of female education, and of the many improvements which she has labored, not unsuccessfully, to introduce in its various departments. The love of teaching appears to have been a ruling pas- 
sion of her mind, and was developed in her early years. After receiving the advantages of the common schools, and enjoying for two winters, the instruction of Doctor Miner, then an eminent teacher in the Berlin academy, she, at sixteen years of age, took the charge of a district school in her native town. The following year, she opened a select school, and in the summer of the next year, was placed at the head of the Berlin academy. During this period, being engaged at home throughout the summer and winter in the capacity of instructress, she managed in the spring and autumn, to attend one or other of the two boarding schools at Hartford.

During the spring of 1807, Miss Hart received invitations to take charge of academies in three different states, and accepted that from Westfield, Massachusetts. She remained there but a few weeks, when upon a second and more pressing invitation she went to Middlebury in Vermont. Here she assumed the charge of a female academy, which she retained for two years. The school was liberally patronized, and general satisfaction rewarded the efforts of its preceptress. In 1809 she resigned her academy, and was united in marriage with Doctor John Willard, then marshal of the district of Vermont, and for several years, a leader of the republican party of that state.

In 1814 Mrs. Willard was induced to establish a boarding school at Middlebury, when she formed a determination to effect an important change in female education, by the institution of a class of schools of a higher character than had been established in the country before. She applied herself assiduously to increase her own personal abilities as a teacher, by the diligent study of branches with which she had before been unacquainted. She introduced new studies into her school, and invented new methods of teaching. She also prepared "An 29 
Address to the Public," in which she proposed "A Plan for improving Female Education."

Her school at Middlebury had obtained so much celebrity, that she had many boarding scholars sent her from the first families in the state of New York, five of whom were from Waterford. One of the five was an adopted daughter of General P. Van Schoonhoven, the lovely and interesting Frances Davis, (since Mrs. Kirkland, and now no more). The general wished Mrs. Willard to remove her school to Waterford. Her husband, who it is said had been basely treated by his political friends, and who moreover warmly sympathized with the views of his lady in elevating the character and condition of women by education, was perfectly willing to abandon a state in whose foundation he had been one of the chief laborers, provided the way should be fairly opened.

General Van Schoonhoven, on inspecting the "Plan," heartly approved it; and taking a copy, exhibited it to the leading men of Waterford, among whom was the Hon. John Cramer. At their recommendation, a copy was sent to Governor De Witt Clinton. The latter immediately wrote to Mrs. Willard, expressing a most cordial desire that she would remove her institution to the state of New York. He also recommended the subject of her "Plan" in his message to the legislature. The result was, the passage of an act to incorporate the proposed institute at $W$ aterford, and another to give to female academies a share of the literary fund, being it is believed, the first law ever passed by any legislature with the direct object of improving female education.

During the spring of 1819 Mrs. Willard accordingly removed to Waterford, and opened her school early in the ensuing summer. The higher mathematics were introduced, and the course of study was made sufficiently complete to qualify the pupils 
for any station in life. (The first young lady who was examined publicly in geometry, and perhaps the first instance in the country, was Miss Cramer, since Mrs. Curtis.)

In the spring of 1821 , difficulties attending the securing of a proper building for the school in $\mathrm{W}$ aterford, Mrs. Willard again determined upon a removal. The public spirited citizens of Troy offered liberal inducements; and in May, 1821, the Troy female seminary was opened under flattering auspices, and abundant success crowned the indefatigable exertions of our authoress. Since that period, the institute has been well known to the public, and the name of Mrs. Willard, for more than a quarter of a century, has been identified with her favorite academy. In the autumn of 1830, having been left a widow four years, and being now in impaired health, she left this country and sailed for France. She resided in Paris for several months, and from thence visited England and Scotland, returning in the following year. After her return she published a volume of her travels, the avails of which amounting to twelve hundred dollars, were devoted to the cause of female education in Greece. It may be proper to add, that she devoted the avails of one or two other publications to the same object.

In 1838, Mrs. Willard resigned the charge of the Troy seminary, and returned to Hartford, where she prepared for publication her celebrated Manual of American History, for the use of schools. The merits of this work, her United States History, and Universal History, have been attested by their very general use in seminaries of education.

Since 1843 , she has completed the revision of her historical works, revised her Ancient Geography, and, in compliance with invitations, has written numerous addresses, on different occasions, being mostly on educational subjects. Two of these were written by request of the Western Literary Institute 
and College of Teachers, and were read at annua. meetings of the society, at Cincinnati, one in 1811, and the other in 184:3. In 1845 , by special invitation, she attended the convention of county and town superintendents, held at Syracuse. She was invited to take part in the public debate-declining that honor, the gentlemen of the convention, to the number of about sixty, called on her at her lodgings, where she read to them a prepared address. The principal topic of it was, "that woman, now sufficiently educated, should be employed, and furnished by the men, as committees, charged with the minute cares and supervision of the common schools;" reasoning from the premises, that to man it belongs to provide for the children, while upon woman it is incumbent to take the provision, and apply it economically and judiciously. These sentiments were received with decided approbation.

In the fall of the same year, 1845, Mrs. Willard made, with great satisfaction, an educational tour, through some of the southern counties of New York, having been specially invited to attend the institutions for the improvement of teachers of the common schools. At Monticello, Binghamton, Owego, Cairo, and Rome, she aided in instructing no less than five hundred teachers of these schools, and in many cases her partings with the young female teachers were not without tears.

The inhabitants of the places where she went, to instruct teachers, desiring to have a share in her visits, at their request she attended public meetings of both sexes, where she introduced resolutions, which were unanimously passed, in the several counties, and aided in the debates. The object was to forward her scheme, of giving to the best educated, and most able women of the country, the charge and supervision of the village schools, for little children, especially of those things appertaining to the conveniences of such schools. That the 
teachers of these schools should be mostly females, is now universally agreed; but, argued she, while the young women can be the teachers, it needs the matrons, acting under the authority of the men, to aid in the supervision.

In the ensuing winter of 1846 , Mrs. Willard prepared for the press a work, which has given her more fame abroad, and perhaps at home, than any of her other writings. This work, which was published in the ensuing spring, both in New York and London, developed the result of a study which had intensely occupied her at times, for fourteen years. Its title is-A Treatise on the Motive Powers which produce the Circulation of the Blood. And its object is, nothing less than to introduce and to establish the fact, that the principal motive power which produces circulation of the blood, is not, as has been heretofore supposed, the heart's action, that being only secondary, but that the principal motive power is respiration, operating by animal heat, and producing an effective force at the lungs. Of this work, the London Critic thus speaks:

"We have here an instance of a woman undertaking to discuss a subject that has perplexed and baffled the ingenuity of the most distinguished anatomists and physiologists, who have considered it, from Hervey down to Paxton; and what is more remarkable, so acquitting herself as to show, that she apprehended, as well as the best of them, the difficulties which beset the inquiry, perceived as quickly as they did, the errors and incongruities of the theories of previous writers; and lastly, herself propounded an hypothesis to account for the circulation of the blood, and the heart's action, eminently entitled to the serious attention and examination of all who take an interest in physiological science."

During the spring and summer of 1846, Mrs. Willard made the tour of the southern and western 
states, visiting every one of them, except Texas. In every city, she met her former pupils, who gave her a filial welcome. She was received by the principals of schools, and those employed in education, as an "educationalist;" and, as such, invited to visit, and to address schools-where, in many instances, she received public testimonials of consideration.

In addition to the compends of history which she has written, she has invented, for the purpose of teaching and impressing chronology on the mind by the eye, two charts, of an entirely original character-one called, The American Chronographic for American History, and the other, for universal history, called the Temple of Time. In the latter, the course of time, from the creation of the world, is thrown into perspective, and the parts of this vast subject wrought into unity, and the most distinguished characters which have appeared in the world, are set down, each in his own time. This, in the chart, is better arranged, for the memory, than would be that of the place of a city, on a map of the world.

Very recently, Mrs. Willard has published a pamphlet, in which she sets forth that certain grievous trespasses have been committed upon her literary property. It proves that she is well able to verify the motto of the celebrated Scottish chief"touch and I pierce."

The poetical compositions of Mrs. Willard are few, and are chiefly comprised in a small volume printed in 1830. The following will serve as a specimen. It was written while on board the packet Sully, on her return from Europe, in 1830; and, being set to music by Count de Enoiseul, a fellow passenger, was sung as their evening hymn during the remainder of the voyage. It was afterwards set to music by the celebrated English vocalist and 

composer, Knight, and sung in public, by him and others:

\section{THE OCEAN HYMN.}

Rock'd in the cradle of the deep,

I lay me down in peace to sleep;

Secure I rest upon the wave,

For thou, O Lord, hast power to save.

I know thou would'st not slight my call,

For thou dost mark the sparrow's falt;

And calm and peaceful is my sleep,

Rock'd in the cradle of the deep.

And such the trust that still were mine,

Tho' stormy winds swept o'er the brine,

And tho' the tempest's fiery breath

Rous'd me from sleep, to wreck and death:

In Ocean's cave, still safe with Thee,

The germ of immortality;

And calm and peaceful is my sleep,

Rock'd in the cradle of the deep.

\section{JAMES R. WHITING,}

Late district-attorney for the county of New York, is a remarkable instance of what may be accomplished by untiring perseverance. Poor in early life, he adopted the profession of the law, and has risen, to his great credit and honor, to his present high position in the estimation of his fellow citizens.

As a speaker, he is clear, close, pointed, and occasionally rather bitter. This, however, may be attributed to ill health, to which most lawyers, who, owing to the zealous prosecution of their profession, neglect proper bodily exercise, are subject. It is difficult for a man to exercise forbearance under 
the goadings of opposing counsel, when suffering from indigestion. In olden times, the lawyers were not wont to neglect the exercise of the body. For instance, it appears from Goodwin's Social History of Great Britain, that "dancing formed a part of their education. It served to give them exercise, and thus promoted mirth and cheerfulness, amid their monotonous studies."

In the reign of James I., the barristers used to dance before the judges; and the judges used to dance at their antique masks and revels at their respective inns.

Mr. Wynne, in his notes on Eunomus, mentions a recent case, in which the learned judges "tripped it merrily, on the light fantastic toe " the last revel, he says, which was held in any of the inns of court, was at the Inner Temple, 1722, in honor of Mr. Talbot, when he took leave of the house, of which he was a bencher, on having the great seal delivered to him.

After dinner, the master of the revels, who went first, took the lord chancellor by the right hand, and he, with his left, took Mr. Justice Page, who, joined to the other judges, sergeants, and benchers present, danced round about the coal fire, in the middle of the hall, according to the old ceremony of those times-during which they were aided in the figure by Mr. Cook, the prothonotary, then upwards of sixty years old. 



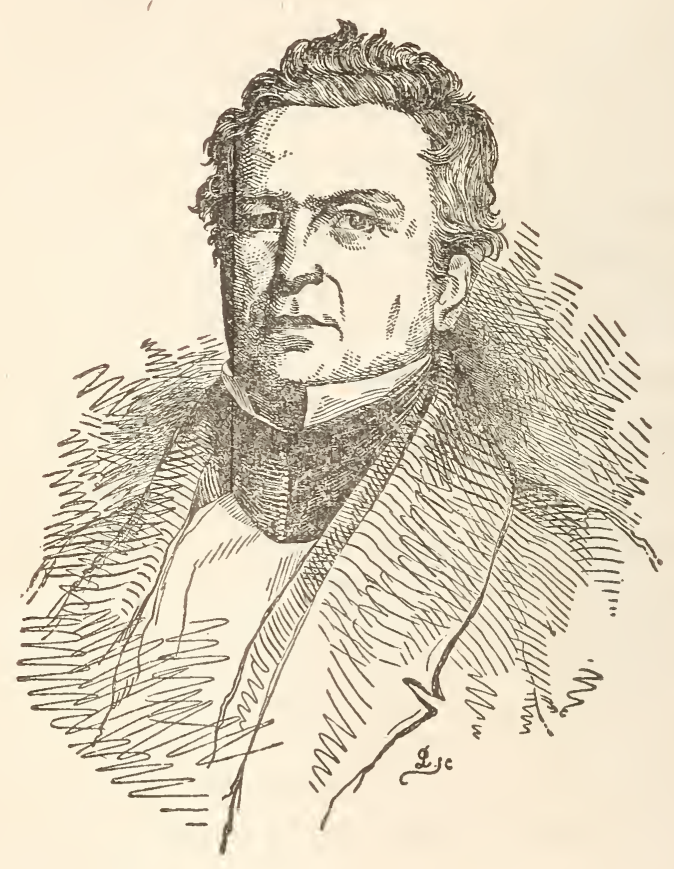

LELAND HOWARD. 


\section{LELAND HOWARD.}

The ancestors of this successful baptist preacher, were descendants of the Howards of England, and were among the earliest settlers of the Plymouth colony. His grandfather, Benjamin Howard, in 1760, removed from Massachusetts to Windham county, Vermont, where Calvin the father of Leland was born. Calvin was the youngest of nineteen children. He married Hannah Willman, who presented him with no less than twelve "pledges," all of whom in due time, became members of baptist churches. Calvin and his wife were the first baptists in that part of Vermont, and they had to go twenty-two miles to hear their pastor, the Rev. Aaron Leland, afterwards speaker of the Vermont legislature, and lieutenant governor of the state. After him their third son, the subject of this sketch, was named. He was born at Jamaica, Windham county, Vermont, on the 14th of October, 1794. The circumstances of his parents were not such as to exempt the family from the necessity of labor; but Leland, from the earliest period, manifested a decided repugnance to bodily exertion of any kind unless connected with amusement, much preferring to sit in some corner where he would sing by the hour. This disposition frequently brought him into trouble. On one occasion, when about ten years of age, he was taken by Calvin, an elder brother, to work in a garden at some distance from home. After assigning him his task for the day, Calvin would leave him, but generally on returning in the evening, he would find the hoeing and weeding neglected, and Leland lying on his back lustily singing all sorts of hymns in all imaginable metres. This derilection of duty, subjected him to sundry 30 
practıcal admonitions from the hands of his guardian brother, which however effected nothing more than causing Leland to sing in a different key. At this day, the brothers, between whom the warmest affection has ever subsisted, cannot revert to that incident without laughing until the tears roll down their cheeks.

A few years afterwards, Leland accompanied Calvin upon a midnight excursion to shoot a bear, which was in the practice of depredating upon a corn field about that hour. They took with them an old revolutionary musket, heavily loaded with slugs. They stationed themselves near a large tree, and before it became quite dark had abundance of courage, and dared Bruin to "come on and meet his fate." Towards midnight however, a distant sound was heard resembling the crackling of dried branches, whereon Leland crept close to Calvin, whilst the latter nervously seized the old musket and felt that the priming was good. Unconscious of the presence of two such heroes with their munitions of war, the bear

"True as the needle to the pole,"

was steadily advancing to the corn field. At this critical juncture, whether with a design of enticing the enemy into an ambuscade or not is immaterial, but Leland ran off "homeward bound," like lightning, and Calvin, having a valid excuse in the desertion of his ally, discharged the gun in the air and also sought safety by flight. After that night, there is no record of another expedition being planned against the bear.

As an illustration of the peculiar observances among the scholars in the academies of that day, it may be interesting to advert to an incident which occurred when the brothers, for a brief period, were sent to a school in their vicinity. On entering the play ground, they observed the other boys in deep 
consultation, occasionally casting earnest glances at the new comers. At length two boys about their own age, advanced, and each selecting his "man," commenced a personal attack. This being promptly returned, a cry of "enough," was heard from the spectators, whereon an explanation took place to the effect, that this was a kind of "by-law," adopted in order to test the mettle of new "jecruits," and with a view of ranking them accordingly. A general introduction then took place, and Leland and Calvin became a part of the "regular army."

So jovial and frolicsome was the disposition of Leland, and so grave that of his brother, that it was predicted the latter would certainly become a minister, while such a profession was never even dreamt of for the former. But Calvin became a physician, and Leland with all his glee became a "teacher in the church." At the age of eighteen, although extremely illiterate as regards book learning, he commenced preaching. His great natural talents soon attracted the attention of General Abner Forbes, of Windsor, who sent him to Boston and gave him a gratuitous education.

Had every man thus expended a small portion of his superfluous wealth, how much talent might have been discovered for the church, for the state, and for the world, among those untutored multitudes of our race, who have floated unknown and unnoticed down the tide of time? "How many gems made visible by their glittering, would have been collected? How many mines of beauty and richness would have appeared? How many Demosthenes might have lightened and thundered? How many Homers soared and sung? How many Newtons roused into action, to develope the laws of matter? How many Lockes to explore the regions of mind? How many Erskines to adorn the bar? And perhaps some other Washington, whose memory has now perished in obscurity, might have been freed 
from the factory or the plough, to decide the fate of battle, and sustain the weight of empire."

In $1816 \mathrm{Mr}$. Howard became pastor of a baptist church at Windsor, where he remained for six years, until his removal to Troy, New York, where he preached until 1829. During his residence at the latter city, the honorary degree of A. M. was conferred upon him by Middlebury college. In compliance with the wishes of his early friends, he subsequently returned to Windsor, where he labored with much success for five years. His next field was Brooklyn, where he resided until 1837. He has since been stationed at Minden, Connecticut, Newport, Rhode Island, Norwich, Chenango county, and again at Troy, where a beautiful building was erected for the new church over which he presided. He is at present preaching at Hartford, New York.

A striking peculiarity of Mr. Howard is an arersion to writing, owing to which he can scarcely ever be induced to execute a long letter. Rather than fill a couple of pages, he would, it is believed, take a long walk to deliver a verbal message. In 1822 , on some particular occasion, he preached before the Vermont legislature. The sermon gave so much satisfaction, that a resolution of thanks was adopted, accompanied by a request for a copy for publication. But preaching was one thing, and writing another, and the sermon remained among the "unwritten things." But although indolent in regard to such matters, there are thousands who will bear witness of his energy and faithfulness in the discharge of his professional duties. Here no obstacles can deter him. Integrity, unflinching perseverance, benevolence, and a spirit of self-sacrifice, whenever occasion calls for it, are prominent traits in his character. He has a voice of much compass, strength and richness, and does not by any means rank with those preachers, who are always lulling their hearers into a refreshing slumber. 
His sermons too are short, for he, unlike many others, believes that "where weariness begins, profit ends." He does not spend half an hour before the mirror previous to entering the pulpit, nor is he one of those who appear to think the arrangement of their hair, the adjustment of their cravats, or the cut of their coats, of more importance than the salvation of an immortal soul. Having none of the pedantry of learning, he possesses that sort of resistless persuasiveness, the power of which is "as much in the manner of saying, as in the thing said."

In 1845 he was a passenger on board the ill-fated steamer Swallow which sunk in the Hudson river, and where, at the imminent peril of his life, he rescued several persons from a watery grave.

In his domestic relations he is particularly happy, having an amiable wife and eight children. James L. Howard, the eldest, married Miss Anna Gilbert, the accomplished daughter of the Hon. I. B. Gilbert, of Hartford, where, with several other members of the family, they at present reside. Lucy, the eldest daughter, married Charles Miller, Esq., of Moriah, Essex county, New York. 


\section{CALVIN HOWARD,}

Brother of the subject of the preceding sketch, at the age of nineteen, left home, with a view of finding an eligible location for teaching school. While getting some refreshment, at a tavern in Hobart, Delaware county, he attracted the notice of Doctor Gregory, of that place, who, after a long conversation, engaged him as a teacher in his family. Gregory, although an eccentric character, was an able physician. With him, Howard studied medicine, and, by intense application, soon qualified himself for practice. He subsequently married Sarah, the sister of his preceptor, and shortly afterward removed to Haverstraw, on the Hudson, where he received liberal encouragement in his profession.

While at Haverstraw, he, with others of his neighbors, was called down to New York city, to repel a threatened invasion of the British. So sudden was the summons, that he had to leave his horse behind him, at some distance from home. During the few days he remained in the city, he was nearly killed with the camp fare; which, according to the testimony of numerous sufferers, was calculated to do more execution than the balls of the enemy.

One night the company to which he belonged were quartered in a large building, in sight of the East river, in hourly expectation of the descent of the British. While there, a short, fat Dutch officer, the market valve of whose courage was not much above par, strutted up to the door, and waving his long sword, shouted-

"Come, poys, don't ye pe afeard. Look at me! I aint a pit more afeard than as if I was up to home!" 


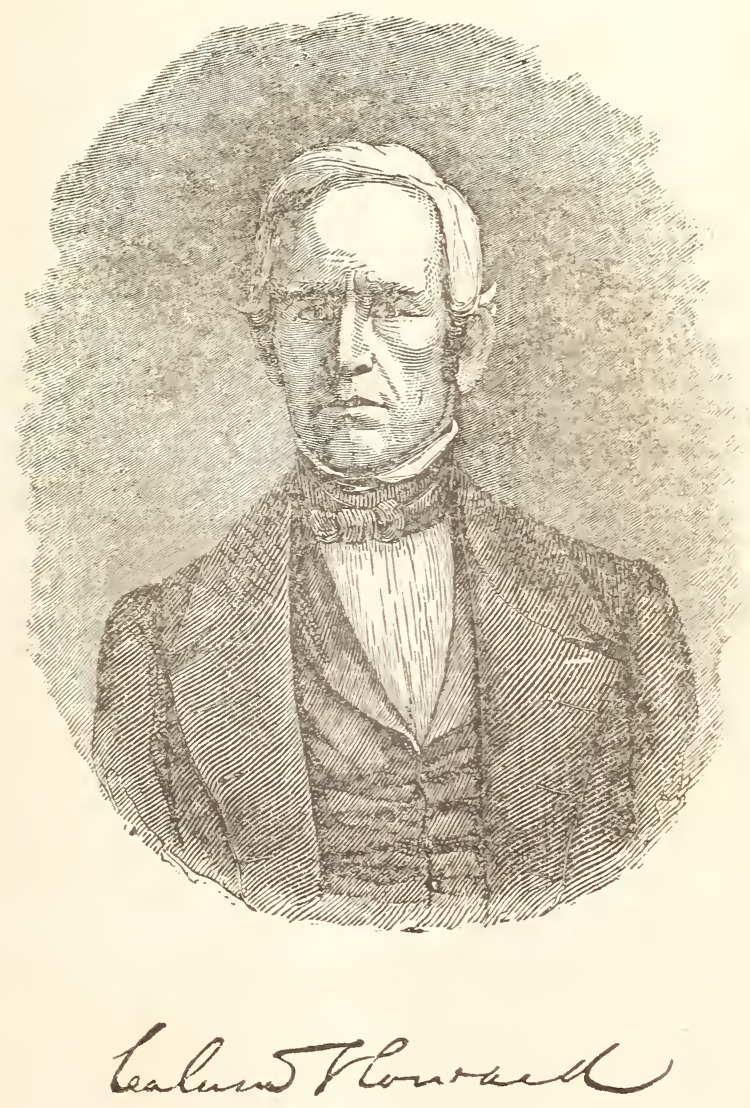



A representation being made to the right quarter, that the village of Haverstraw was left without a single doctor, a fact which jeopardized the safety of numerous embryo patriots, Howard was permitted to return.

In 1817, the subject of our sketch returned to Hobart, where he practised medicine for upwards of thirty years. A few years since, his first wife, a lady of great energy of character, after a lingering illness, paid the debt of nature. On a grassy hillock, nestled among the green mountains of that delightful region, repose her remains, in the same grave with her grand-daughter, a fair-haired girl, who entered the world of spirits exactly twelve months after the death of the former. A few weeks previous to her departure, and while in perfect health, Emma desired to be taken to see the bed on which "grandma died." Her wish was gratified, whereon she said: "There, that will do; now take me home;" and very shortly, amidst the howling blast of a winter day, the earth was dug from the coffin of "grandma," and the bodies of the two were reunited in the icy arms of death. But, though cold was their pillow, and the icicles were the drapery of their couch, the eye of faith could discern their spirits in the eternal sunshine of Eden, rejoicing amidst the "great multitude of angels, which no man can number," where there is no pain, because. there is no sin, and where ransomed millions, through the sufferings of the Savior, triumphantly exclaim: "O Death, where is thy victory? $O$ Grave, where is thy sting?"

Very recently, Dr. Howard married Emeline P. Ten Broeck, a highly accomplished lady, who was for many years preceptress of the Female academy, at Delhi, in which place they now reside.

Dr. Howard was one of the earliest pioneers in the glorious cause of temperance; and, after years of indomitable perseverance, through violent oppo. 
sition, involving great pecuniary sacrifice, he has lived to see the almost universal triumph of his principles. From early youth he has been a member of the Baptist church, and he has held many offices of honor and trust. By his first wife, he had six children, who are all living.

\section{JOHN W. EDMONDS.}

The father of this distinguished jurist was born in the city of New York, at what is now the corner of William and Liberty streets, on the 27th of August, 1760. When the war of the revolution broke out, he was a student, at college, in Rhode Isląnd. He, however, immediately left his studies, and enlisted in the army as a private soldier. In various capacities, he served during the whole war, having risen from the ranks to an ensigncy, and finally to an assistant commissary. He was at the battles of Monmouth, Yorktown, etc. On the establishment of peace, at the age of twenty-three, he started to seek his fortune, having nothing but a horse, saddle, bridle, two blankets, and a little continental money. In 1784, during his wanderings, he arrived at the site of what is now the city of Hudson, then called Claverack landing. There, as one of the few settlers, he opened a small store, in which business he was found by the emigrants from Nantucket and Martha's vineyard, who purchased the land and laid the foundation of the city. He was at one time a member of the assembly, and high sheriff of the county, and he continued in trade

- until the war of 1812 , when he again entered the service of his country. He was soon appointed paymaster-general of the militia, in which office he 
continued for several years after the termination of the war.

He died at Hudson, in 1826, and within a few years, a beautiful monument has arisen in its graveyard, erected to his memory by his sons. His wife, the mother of the judge, was Lydia Worth, daughter of Thomas Worth, one of the first settlers of Hudson. She was a descendant of William Worth, who emigrated from Devonshire, England, in 1640, and settled in Nantucket. From this common stock have descended, Major-General Worth, of the United States army; G. A. Worth, Esq., president of the New York City bank; and the Olcott and Edmonds families.

After the death of Gen. Edmonds, his widow resided chiefly with her son, the judge, until she died, on the 20th of November, 18t1. She was a member of the society of Friends, and instilled into her children many of the tenets of that respected sect, which have evidently influenced their conduct through life.

Judge Edmonds was born in the city of Hudson, on the 13th of March, 1799. His early education was at private schools, and at the academy at Hudson, where he prepared for college. In October, 1814, he entered the sophomore class, of Williams college, Massachusetts, in company with John Birdsall, afterwards circuit judge of the eighth circuit, and attorney-general of Texas. In 1815, he solicited his dismissal from the college, and entered Union college, at Schenectady, where he graduated in July, 1816. His share in the exercises of the commencement, was the Fall of Poland. On leaving college, he began the study of the law, at Cooperstown, with George Monell, Esq., afterwards chief justice of Michigan. After remaining at that place about six months, he returned to Hudson, where he studied two years, in the office of MIonell \& Van Buren. 
In the fall of 1819, he entered the office of Martin Van Buren, in Albany. He continued with the ex-president, residing in his family, until May, 1820, when he returned to Hudson, and entered upon the practice of the law. He continued at Hudson, until his removal to New York, in November, 1837.

Inheriting the military disposition of his father, we find the judge, at the age of nineteen, a lieutenant in the militia, which commission he held for about fifteen years, when he obtained the command. of his regiment. This office he resigned, in 1828, on being appointed, by De Witt Clinton, recorder of Hudson. To this day, throughout the old county of Columbia, the judge is addressed as colonel, military honors appearing invariably to take precedence of all others.

At an early age, he took an active part in politics, ranking himself as a democrat, and the first vote he ever gave was for Daniel D. Tompkins, when he ran for governor, against De Witt Clinton.

In 1830 , the judge was elected by the democrats of Columbia, to the assembly, in which body he soon became a leading and influential member.

In the fall of 1831, he was elected to the state senate, receiving, in his district, an unprecedented majority of over 7,500 votes.

In the senate, he served four years, during the whole of which time, in addition to other duties, he was a member of the judiciary committee, and for the last three years, chairman of the bank committee.

It was also during his senatorial term that the subject of nullification, arising out of the forcible resistance of South Carolina to the tariff laws, occupied the public mind. A joint committee of the two houses was raised on the matter, and the judge was a member on the part of the senate. An elaborate report, drawn up by Mr. Van Buren, then 
vice-president of the United States, was made by Mr. N. P. Tallmadge, the chairman of the committee. About that time, Mr. Tallmadge was elected to the United States senate, and opposition to his report on nullification unexpectedly arising, the defence of it devolved upon Judge Edmonds. The debate lasted more than a week, during which time the judge stood alone against six of the most prominent senators on the other side. The result was the adoption of the report by an overwhelming majority.

In 1834 the judge was chairman of a joint committee of the two houses, to whom was referred the subject of the United States bank, which its opponents alleged was creating pecuniary distress, with a view of extorting from congress a renewal of its charter.

In the summer of 1836 Judge Edmonds was appointed by General Jackson, a commissioner to carry into effect the treaty with the Ottawa and Chippewa tribes of Indians. This business took him during the summer to Michilimackinac, where for nearly two months, he was encamped with over six hundred natives. In the ensuing year he received appointments in relation to other tribes, but in the fall of 1837 he relinquished them and removed from Hudson to New York, where he resumed the practice of law. He almost immediately, found himself in an extensive and profitable business among the merchant princes of the commercial emporium.

In April, 1843, without any solicitation on his part, the judge was appointed by Governor Bouck, an inspector of the state prison at Sing Sing. It was with much hesitation that he accepted this unthankful task. The labor was indeed Herculean. Scarcely any discipline was main tained in the prison, and the female prisoners had the entire control of their officers; hundreds of the males were entirely idle, 
and the earnings fell short of the expenses by over $\$ 40,000$. But within eighteen months, a great change was effected, and the female portion of the prison was brought into complete subjection. Strict discipline was introduced and maintained among the males, and the annual deficiency in the revenue was reduced to less than a tenth part of the former sum.

This task, however, was easy in comparison with a reform of a different character which be sought to introduce. He found, that for more than fifteen years, the system of government which had prevailed in our state prisons, was one purely of force; and where no sentiment was sought to be awakened in the breast of the prisoner but that of fear, and no duty exacted from him but that of implicit obedience. No instrument of punishment was used but the whip, which had the effect of arousing only the worst passions of both convicts and officers-a practice of abominable cruelty, long engrafted upon our penitentiary system - revolting to humanity, and destructive to all hope of reforming the prisoner. So thoroughly had it become engrafted, that the most experienced officers insisted that there was no other mode by which order could be kept. Besides, they found it was then so very easy to govern in that way.

Passion, prejudice and selfishness, all combined to place obstacles in the way of this proposed reform, and its progress was very slow. Yet it steadily advanced, and when in 1845, the judge resigned the office of inspector, his system was in the full tide of experiment. It has been continued by his successors to the present time. It has also been introduced into the state prisons at Auburn and Clinton, and is now the governing principle in all our state penitentiaries. With a view of carrying out his plan, in December, 1844, he instituted a "Prison Discipline society," the object of which is the reform 
of prison government and the aiding of prisoners, on their discharge, to lead honest lives. This society is in very successful operation, and enjoys a large share of public confidence. How great an amount of good can be accomplished by a single philanthropic individual; and for this one movement of the judge, how many poor wretches will rise up and call him blessed! For this the tear of gratitude shall fall upon his grave, while angels proclaim that, "he who turneth one sinner from the error of his way, shall shine as the stars forever." "Man dies, but not one of his acts ever dies. Each perpetuated and prolonged by interminable results, affects some beings in every age to come."

On the 18th of February, 1845, Mr. Edmonds received the appointment of circuit judge of the first circuit, in the place of Judge Kent, who had resigned. That office he held until June, 1847, when he was elected a judge of the supreme court.

In the discharge of his duties as circuit judge, he was always fearless and independent, reminding us of the famous Matthew Hale. A most extraordinary instance of this was exhibited at the anti-rent trials in Columbia county, in September, 1845. The counsel employed in those trials, had been engaged in the same cases at the circuit in the March preceding, and had then manifested no little combativeness. They displayed the same warmth before Judge Edmonds, and carried it so far as to come to blows in open court. The offenders were gentlemen of high standing, and personal friends of the judge, and both at once apologized for their contempt of court. But the judge, with great promptness, committed them both to prison, and adjourned his court with the remark, that it was not his fault that the cause of public justice was thus interrupted. Perhaps none regretted this momentary outbreak more than the parties themselves, whose manners in private life are courteous in the extreme 
This event attracted a great deal of attention throughout the Union, and was noticed by European papers as "evidence of advancing civilization in America." The most gratifying feature of the case was, that it did not disturb the personal good feeling which had previously existed between the parties engaged in it.

Upon the organization of the judiciary, under the new state constitution, Judge Edmonds was nominated for justice of the supreme court by the bar of New York, and by the Tammany party, and was elected by a majority exceeding any of his colleagues. This result cannot but be gratifying not only to him, but to the public, inasmuch as during his judgeship he had made several decisions that warred upon popular prejudice, and immediately before his election he had, with others of the democratic party, protested against the admission of Texas into the Union, as eminently calculated to lead to a war with Mexico and to perpetuate the extension of slavery. Subsequent events have justified the sagacity which marked that act, while the act itself has subjected the gentlemen engaged in it to much obloquy and censure from their political associates. This proceeding was, however, rebuked in his triumphant election by the public, who honored him for his independence of character.

The judge has one brother, Francis, cashier of the Mechanics' bank in New York, and somewhat distinguished as an artist. He has also three sisters, two of whom reside in the state of New York, and the third, the wife of Colonel Webb of the United States army, is living in Illinois.

The family of the judge consists of three daughters, two of whom are married. 


\section{ERASTUS ROOT.}

The late General Root, whose name has been so long identified with the history of our country, was a native of Hebron, Connecticut. He was born on the 16th of March, 1773. The maiden name of his mother was Baldwin. His father, William Root, born on the 31st of August, 1731, was also a native of that place. His grandfather, whose name also was William, was born at Northampton, Massachusetts, in 1695. The latter went to Hebron, with his father, Jacob Root, who removed with his family to that place, in 1705 . Jacob was a native of Hartford, from which town he, with his father, Thomas Root, removed to Northampton.

Erastus pursued his collegiate education at Dartmouth college, teaching school in the winter months. He graduated at that institution, with high honor, at a very early age. He studied law with Sylvester Gilbert, a distinguished lawyer of Hebron. He was licensed to practise law in the spring of 1796. In that year, he removed to Delaware county, New York, (then Otsego, west of the Delaware river, and Ulster on the east.) He settled in Franklin, in which town was then included the present villages of Delhi and Walton, with the view of practising his profession.

The following year, being then only twenty-four years of age, he was elected to the legislature of New York, as a representative from the county of Delaware. From that time up to 1843 , he represented the county in various ways, in both branches of the legislature, in congress, and in the constitutional convention of 1821 .

In 1801, he was in the state senate, and was one of the members who voted for the Jefferson electors 
(electors for president and vice-president being then chosen by the legislature). In 18?3, and 1824, he was president of the senate, during which time he was lieutenant-governor of the state.

His legislative career may be summed up as follows: Member of the assembly, eleven years, three of which he was speaker; member of congress, nine years; state senator, eight years; and president of the senate, and lieutenant-governor, two years; also, member of the constitutional convention of 1821, one year. It is a curious fact, that during his first two legislative terms, he was the youngest member of the legislature, ; and, during the last two years, he was the oldest member!

He was appointed, by the legislature, one of the persons to revise the laws of the state; but, it is believed, he resigned before the revisers met. His term, as state senator, expired in 1843, on which he retired from public life.

Mr. Hammond, speaking of Gen. Root, in 1813, says of him:

"Though a little uncouth in his manner, and rough, and I fear somewhat rude in his expressions, his wit was keen, and his sarcasms severe and biting. He seized with great force and effect upon the prominent points, and especially those points most likely to make an impression on the popular ear, and pressed them with a power almost irresistible. His illustrations were exceedingly clear and well chosen, and his attacks upon his opponents were severe in the extreme. From the year 1798, down to this period, he had been almost continually a member of the state or national legislature, and possessing, as he did, a most retentive memory, he was perfectly at home upon all matters relating to the action of goverment, and the operations of the two great political parties. He had much parliamentary tact, and although uncouth in his manner, he was a man of correct literary taste, and highly 
cultivated intellect. He was a scholar, and a good and ripe one."

He received his appointment as colonel, in 1803 ; that of brigadier-general, in 1808; and that of major-general, in 1816. The latter office he resigned in 1824 .

On the 4th of October, 1806, he was united in marriage with Miss Elizabeth Stockton, of $\mathrm{W}^{\top}$ alton, Delaware county, who is still living. They had five children; two sons, Charles and William; and three daughters, Julianne, Elizabeth and Augusta. William entered the army as a lieutenant; and is now settled, with his family, as a farmer, in Wisconsin. Charles was a midshipman in the United States navy, and died at Rio Janeiro, of the typhus fever. Julianne is the wife of the Hon. S. R. Hobbie, first assistant postmaster-general. Elizabeth was married to Henry L. Robinson, Esq.; and Augusta, who was married to William Fuller, Esq., of Georgia, died in Alabama, on the 11th of December, 1838.

During the latter portion of his life, while traveling, on several occasions he narrowly escaped death; but his time had not arrived. The shafts of death may fly thick, but their aim is directed by Omnipotence. At best, there is but a step between us and the spirit-land; the bursting of a boiler, the upsetting of a stage, or a crumb of food that we swallow, may be as fatal as the cannon ball. It has been truly remarked, that the small things of life are often of more importance than the great, the slow than the quick, the still than the noisy. "The castle, and the palace, and the church, stand for years the raging of the wind, the beating of the rain, the red bolt of the lightning, yet crumble down beneath the quiet touch of time, without any one seeing where and when the fell destroyer was at work."

For some time previous to his death, Gen. Root 32 
seemed aware of his approaching dissolution. He felt that he could remain this side the grave but a short time. Indeed, it was a theme upon which he frequently dwelt, and with nuch earnestness and feeling. We well remember, says N. Bowne, Esq., of the Delaware Express, a conversation which passed between us, in our office, a day or two before he started on his journey. He said he was leaving Delhi, in all probability, for the last time-that he had passed the age allotted to man, three score years and ten, and was already a probationer some four years. He said he felt his bodily strength failing very fast, and that he believed the time for his departure was near at hand. With this solemn reality strongly impressed upon his mind, he spent some time in closing up his affairs-nor ceased till his earthly house was set in order. While looking upon the venerable face of our departed friend, on Monday, how forcibly were we reminded of the last time we met, but about two weeks before-when he handed us a MS. he desired to be published, saying: "It is, in all probability, sir, the last document I shall ever prepare for the public press." He was right.

He died in the city of New York, at the residence of his nephew, George St. John, Esq., on Thursday morning, the 24th of December, 1846, aged seventy-three years and nine months. His principal complaint was inflammation of the kidneys. His illness was short, and he was soon removed from time into eternity. His remains were carried to Delhi, which place he had left, with his wife, two weeks previously, with the intention of spending the winter at Washington. 



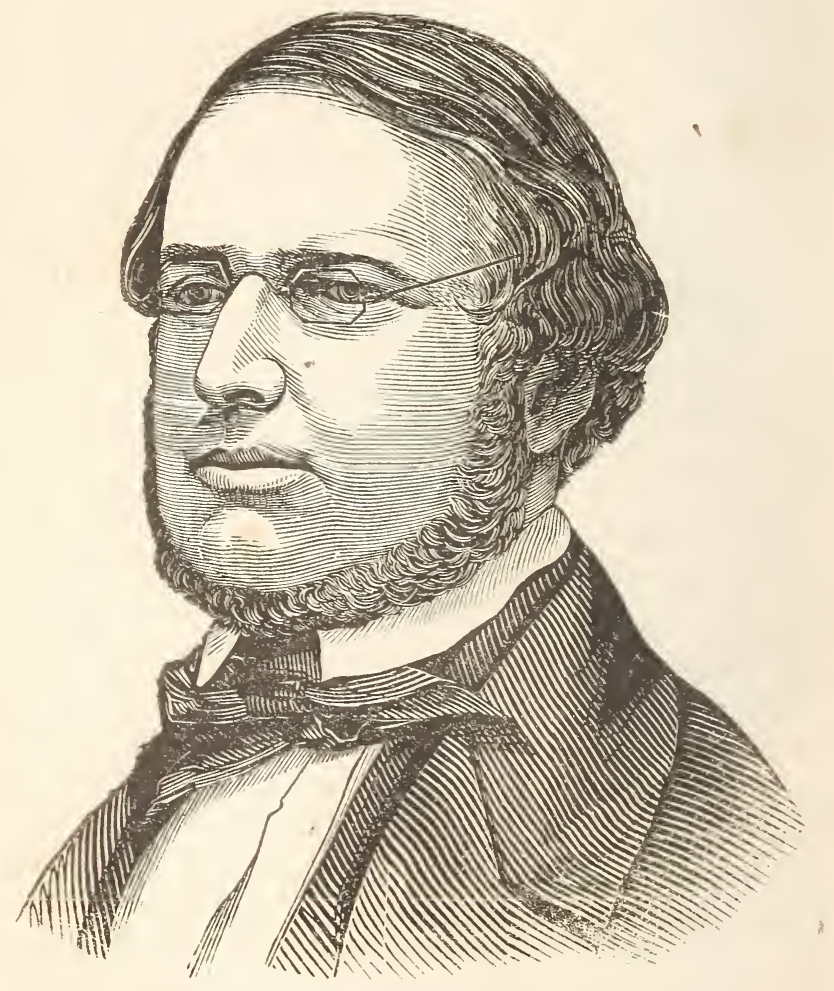

GEORGE FOLSOM 
$\therefore \quad \because$ 


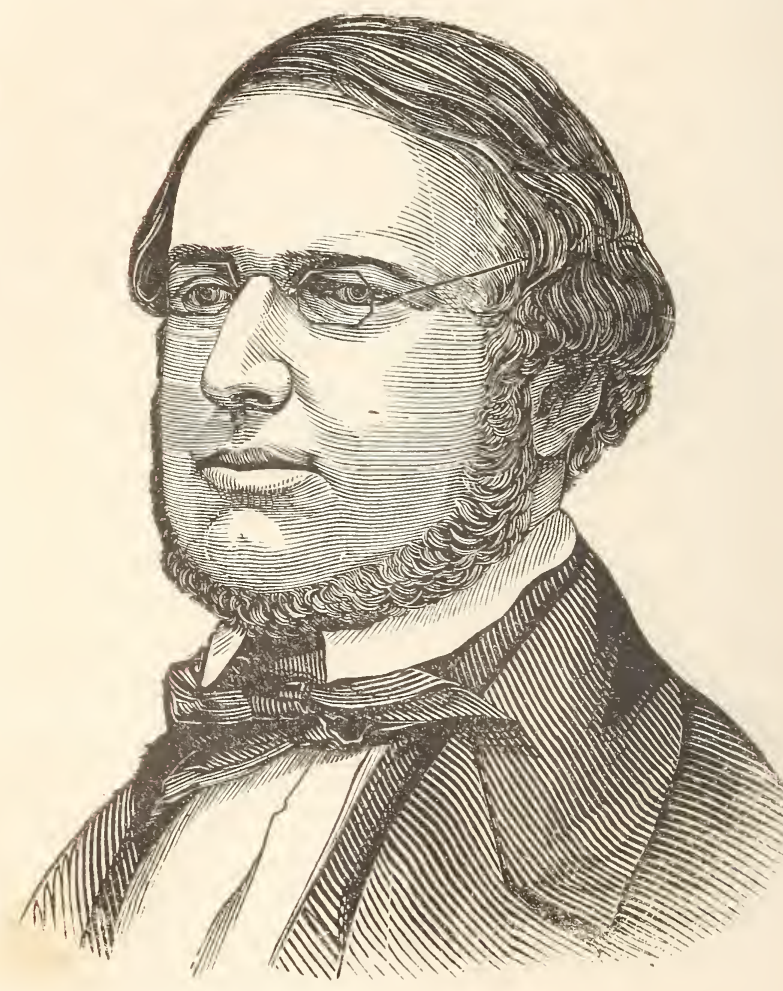

GEORGE FOLSOM 


\section{GEORGE FOLSOM.}

This eminent historical scholar, whose term as a state senator from the district embracing New York city, has very recently expired, is descended from a family of the name at Exeter, New Hampshire, who were among the early settlers of that beautiful village, about two centuries ago. The late General Nathaniel Folsom, so highly distinguished in the war of the revolution, is of the same family.

Mr. Folsom graduated at Cambridge university, in 1822, and studied law in the office of the Hon. E. Shepley, at Saco, near Portland, Me. He commenced the practice of his profession at Worcester, Mass. He subsequently removed to the city of New York, his present residence, where in connexion with his professional duties, he, as a member of the New York Historical Society, has devoted a large portion of his time to the pursuit of his favorite study, American history.

He married the daughter of Benjamin Winthrop Esq., a lineal descendant of John Winthrop, the first governor of Massachusetts. The mother of his accomplished lady was a daughter of Peter Stuyvesant Esq., and the fourth generation from the Dutch governor, whose estates are still in the possession of his descendants. 


\section{PAUL SPOFFORD,}

One of the "merchant princes" of New York, is a descendant of John Spofford, one of those who, in consequence of their religious tenets, came over with the Rev. Ezekiel Rogers to Massachusetts in 1638. John was the first settler of New Rowley, now Georgetown, Massachusetts.

The early life of the subject of our sketch was spent upon the farm, a portion of which has descended to him from his ancestor. But at the age of twenty-two, his taste inclining him to trade, he obtained a situation in a store at Salem, New Hampshire. After remaining there and at Haverhill, Massachusetts, for about two years, he formed a partnership with Thomas Tileston, at that tirne editor of the Haverhill Gazette, and in 1818 went to New York city, where he has since continued to reside.

Mr. Spofford has been twice married. His first wife was the niece and ward of the late Hon. Jeremiah Nelson, member of congress from Newburyport. His present amiable lady is the daughter of the Rev. Dr. Spring, of New York.

What an encouraging example does the career of this eminent merchant afford to young men. It shows that perseverance, united with integrity, will accomplish almost every thing within the sphere of human effort. 


\section{MRS. BAILEY,}

The celebrated heroine of Groton, Connecticut, is still living at that place, where she is post mistress for life. It appears that the industrious editor of the Democratic Review, recently visited the aged "mother," from whom he gathered some interesting particulars.

She distinguished herself greatly in the days of the revolution, but more particularly in the last war with England. On the 13th of July, 1813, the British made demonstrations of an intention to land, and attack New London. The theatre of these hostile movements was too near the many painful incidents of the revolution, not to awaken, instantly, the memory of deep-felt and aggravated wrongs, and to fire the bosoms of the inhabitants, with a spirit akin to that by which they had been actuated in the revolution. No sooner, then, had the British squadron approached, and their object become apparent, than crowds of men, from beardless youth to extreme old age, hurried to the scene of danger, on both sides of the river. All was intense commotion, in expectation of an immediate attack. Old Fort Griswold was again tenanted, by a company of hastily gathered volunteers, under the command of Major Simeon Smith, and every arrangement made for a vigorous and determined defence. The defendants were all animated as one man, and though their means of resistance were meagre, they resolved to make the most of them. Small cannon, the best they had, were planted and manned at the fort; but it was soon discovered that there was an insufficient quantity of ammunition, for a protracted contest. They wanted flannel to make the cartridges, and feared that the time would not allow to 
cross the ferry to New London, in search of it. In this emergency, an individual was despatched to obtain all he could, in the neighboring village of Groton. But, whatever stores the villagers might have had, there was no flannel.

What was to be done? The messenger, almost in despair, called upon Mrs. Bailey for counsel, and made known his wants. He knew, at all events, that she would do every thing in her power to assist him. She at once proposed appealing individually to the occupants of each house in the neighborhood, and they found all ready to give up what they had to spare, whether unfashioned or made into garments. Having completed their respective visits, Mrs. Bailey and her co-laborer met, in the street, and she delivered to him all that she had collected. But, even when added to his, it was found inadequate to the occasion. Mrs. Bailey, however, was not to be defeated in her object. She instantly threw off her petticoat from her own person, where she stood in the street, exclaiming, as she gave it to him, "There, fire that at them!" and the messenger started off immediately to his comrades. The result is known. The enemy, in this case at least, deemed discretion the better part of valor, and did not land. Such is the prominent incident which has won for Mother Bailey an imperishable fame. The effect through the region was electric, and that petticoat, had it been borne aloft as a banner, in the day of fight, would have animated the soldiers of the good cause, had it been necessary, with an ardor as enthusiastic, a courage as undaunted, and an energy as indomitable, as were once inspired in the bosoms of Frenchmen, by the presence of Joan d'Arc. What agency the petticoat had in prosecuting the war, by the way of cartridges, we know not; but of this we are assured, that Mother Bailey feels as proud of the act of its appropriation, as a monarch could of his crown. 
Clean Monce 


\section{ALDEN MARCH.}

It has been well observed, that it is a particular felicity of our republican institutions, that they throw no impediments in the career of merit, but the competition of rival abilities; and into which career it may enter without encountering the repulses of artificial rank, or winning its patronage by unworthy compliances. The history of Professor March, one of the most eminent physicians and surgeons in the United States, affords an additional illustration of this fact.

His ancestors, we perceive, were English. They were among the early settlers of New England, and resided in the town of Newbury, Massachusetts. In the history of that town, the name of March occurs as early as 1653 . In 1651 a sumptuary law had been passed by the town authorities, for the violation of which, in 1653, charges were preferred against the wives of Nicholas Noyss, William Chandler, and Hugh March, for severally wearing a silk hood and scarf. But upon the ladies proving that their husbands were worth two hundred pounds sterling each, the charges were dismissed.

At a subsequent date, the names of John and George March, are found connected with the history of Newbury. The grandfather of Alden, and his father, Jacob March, both resided at Newbury. Jacob was born there on the 17th of July, 1747 . When only seven years of age, Jacob removed with the family to Sutton, Worcester county, Massachusetts. The maiden name of his mother was Eleanor Moore. She was the daughter of Captain David Moore, for some time sheriff of Worcester county.

The subject of this sketch was born in that part of Sutton now called Millbury, on the 20th of Sep 
tember, 1795. He was the youngest of seven brothers. His father was a plain New England farmer, and Alden was brought up to work on the farm, of which, at a very early age, he took the chief management. Like many others similarly situated, his opportunities for school instruction were but very small, and those chiefly in the severe part of the winter. When Alden was nineteen, his father died, whereupon, he became anxious to enter upon a mercantile life. With this view he spent a year in the store of an elder brother, after which he spent a short period at the Munson academy, where, in his $22 \mathrm{~d}$ year, he commenced the study of English grammar. After teaching a district school for a few months, he spent the next spring and summer in cutting house slate at a quarry in Hoosick, Rensselaer county. He subsequently visited the city of New York, where he made an ineffectual attempt to obtain employment in the mercantile business. He then returned to Sutton, Massachusetts, where his brother, a physician, suggested the idea of studying medicine. His objections, however, were strong ones, viz., the want of means, and the want of education. The former, two of his brothers agreed to furnish, and the latter, he resolved to obviate as well as he could. Losing no time, he soon acquired a very respectable stock of Latin and Greek. He also in 1818 and 1819, attended medical lectures at Boston, given by Prof. William Ingalls, then attached to the medical department of Brown university.

Full of ambition, our student embraced every opportunity for acquiring knowledge, particularly those afforded in the dissecting rooms, and by surgical operations. He was also early initiated into the art and mystery of procuring supplies for the dissecting room, the particulars of which, it is presumed, it would not be safe to entrust to other than professional ears. During the vacation he pursued his studies with his brother, and during the haying 
season he worked out at a dollar per day. He attended the next term at Boston, where he had charge of the lecture room and the furnishing of it with "supplies."

In the execution of this delicate duty, it may be readily inferred that Alden had some interesting adventures. During this term it appears that medical institutions in other states, being unable to obtain "subjects," sent agents to Boston, so that there were very soon no less than three "Richmonds in the field," not the field of battle, but Potter's field. The members of the institution to which Dr. March was attached, conceiving themselves to possess a preëmption right, frequently came into collision with the others. On one occasion the body of a drowned sailor was exhumed by the foreign agents, but being disturbed, they were forced to fly, leaving the "subject" kehind a barn near the burial ground. Professor Ingalls hearing of it an hour afterwards, and being aware that should the body be discovered by the citizens, great excitement would follow, sent for Dr. March, and although past midnight, told him that at all hazards, the body must be removed and the grave filled up. Procuring an assistant, and after considerable delay, a horse and wagon, the doctor started; but just as they were leaving the city, the clock struck three. Having not a moment to lose, they dashed forward. On arriving at the burial ground, it was nearly day. light, and the market people were coming into the city. Watching his opportunity, Dr. March, a remarkably strong man, lifted the sack containing the body, weighing at least one hundred and seventy pounds, and carried it to the wagon. Being now after seven o'clock, and broad daylight, they could not venture to return to the city. In this emergency, Dr. March, having a friend who lived at a distance of some miles on the Common, drove there, where the "subject" was concealed in a barn, until the 
return of night afforded an opportunity for conveying it to "head quarters." But the foreign agents declared, although wrongfully, that it was the Boston students who had drove them from the ground, and thus deprived them of the fruits of their labor.

During this term, he with several others formed themselves into a club, and having obtained some of the bones of a skeleton, they alternately lectured to each other, demonstrating the more important parts of the "subject." Perhaps his idea of becoming a lecturer may be traced to this circumstance. He employed all the time he could spare, in making preparations of the different parts of the human body, which he afterwards found of great use. Many of them, in a good state of preservation, may be seen at the museum of the Albany Medical college.

In the fall of 1820, Dr. March graduated at Brown university, receiving the degree of Doctor of Medicine. He soon afterwards left Massachusetts, with the design of settling in Troy, New York. But there being no vacancy, he went to Albany. There he succeeded in obtaining a situation as assistant in the office of Dr. Elias Willard, where, during a year, he posted books, collected accounts, and attended to other office affairs. His compensation consisted in perquisites, which, in all, did not amount to over $\$ 100$, less than half his current expenses.

By this time, however, his collection of anatomical preparations began to attract considerable notice; and the idea occurred to him, that by means of those and a few recent subjects, he could give a course of anatomical instruction to the students of the place, and such others as might feel interested. Accordingly, in the fall of 1821, he commenced lecturing on anatomy and physiology, in Albany, to a small class of some fourteen or sixteen young men, mostly medical students. His first lecture 
was a written one. For the second, he prepared a few notes only, from which he attempted to extemporize. But in so doing, he used up the notes, the subject and himself, by the time the hour was about half through, and had nothing more to say! He was sadly discouraged, and on the point of abandoning the whole matter, when a medical friend urged him to persevere, insisting that to give up under such circumstances, would be the prelude to defeat and disaster in whatever he might undertake. So he determined to persevere, and he succeeded. He then went forward, giving the first course of the kind ever given in Albany. The lecture room was the upper part of a small two story building in Montgomery street, and which had previously been occupied as the Albany Female academy. From this course of lectures, the Albany Medical college may properly date its origin. And it is a curious fact, that these two flourishing institutions should have commenced in the same humble building. How many a flourishing tree has taken root in an obscure corner.

In the spring of 1822, Dr. March commenced for himself the practice of medicine, and the writer has more than once, heard of a remarkable instance of the indomitable perseverance of the doctor in overcoming difficulties. Should this meet his eye, it is presumed he will not disavow it. Having no means of procuring that indispensable requisite to a young doctor, a "subject," he, in a very inclement season, borrowed a horse and waggon from a relative, and drove all the way to Boston, where. Potter's field "suffered some." He started homeward with a brace of subjects, and on arriving at Greenbush, the Hudson river was but just frozen over. He, however, with his "company," dashed across, the ice cracking beneath the wheels the whole distance.

It was in 1822 that the doctor published an article in the Daily Advertiser, suggesting and advocating 
the establishment of a medical college and hospital, in the city of Albany, which subsequently became the subject of much newspaper discussion.

In the fall of that year, he, with four other physicians of Albany, made arrangements for giving a gratuitous sumnary course on anatomy, physiology, theory and practice, materia medica, obstetrics and surgery. It appears, however, that his colleagues did not fulfil their promises, so that Dr. March had to go through the whole course without any assistance. This affair, we perceive, gave rise to considerable correspondence in the newspapers of the day.

On the 22d of February, 1824, Dr. March was united in marriage with Joanna, the fourth daughter of Silas Armsby, of Sutton, Massachusetts. In the summer of the following year, he was appointed professor of anatomy and physiology in the Vermont Academy of Medicine, now called the Castleton Medical college, in which he continued until 1835. The term at Castleton was in the fall; and during the ten years he was professor in that institution, he gave every winter at Albany, a private course upon anatomy, physiology, and operative surgery. By his connexion with the Vermont academy, he became acquainted with Professor Tully, one of his colleagues in that institution, and with whom, in 1827, he formed a business connexion, which continued for three years, and which was of great advantage to Prof. March in extending his literary and scientific acquirements.

In 1832, when the cholera prevailed in this country; it was particularly destructive in the state prison at Sing Sing. A commission of medical men being appointed by Governor Throop to visit the prison, Prof. March was appointed from the city of Albany, and Doctors Stevens, Rhinelander and McNiven were appointed from the city of New York. The pressure, however, of duties, private and public, his 
connexion with the board of health at Albany, together with this visit to Sing Sing, came very near terminating his life.

In the winter of 1832, after a hotly contested election, Prof. March was elected president of the Albany County Medical society.

In the spring of 1833, he, at his own expense, fitted up lecture rooms in the city of Albany, where a course of medical lectures was given by a portion of the faculty of the Vermont academy, and two or three other medical gentlemen of Albany.

Owing to petitions to that effect, which had been for the previous six years, successively presented by Prof. March and others, the legislature passed an act incorporating the Albany Medical college, which institution, it will be remembered, took its rise from the course of lectures given by Prof. March in 1821. It is true, the immediate foundation of the college is due to several others, who united their efforts with his, but all will admit that he is fairly entitled to the credit of originating it. After its incorporation, many obstacles of great magnitude had to be surmounted, and difficulties, growing out of local and general opposition, to be overcome. Owing to the efforts he made during this struggle, and his professional labors, his health was seriously impaired.

In organizing a faculty, the trustees of the college appointed Prof. March to the chair of surgery, which he has ever since filled with high honor to himself and to the institution. The faculty, at their first organization in 1839, elected him president of the college, which office he has continued to hold to the present time.

In the spring of 1841 , with a view of improving his health and the acquisition of professional knowledge, Prof. March visited Europe. He wished particularly to perfect himself in operating for club foot and strabismus or squint eye, having performed 
numerous operations, especially in the latter, previous to witnessing any such operations performed by others. He spent a month in visiting the hospitals, medical colleges, and museums of London, where he had frequent opportunities of witnessing the operations of the most distinguished surgeons. He afterwards travelled through England, visiting all the principal towns. The month of June, in that year, he spent in Paris, where he daily visited extensive hospitals, and witnessed a great number of surgical operations. He also visited the universities, hospitals, \&c., of Edinburgh and Glasgow, where the same facilities were extended to him. He also visited the lakes and highlands of Scotland, from whence he continued his route to the Giant's Causeway, Belfast, and Dublin. After visiting the hospitals of the latter city, he returned to Liverpool, and from thence to Boston, in a Cunard steamer.

In the fall of 1841, he was elected a trustee in the first Presbyterian church of Albany, and during the past year, he held the office of president of the board.

Of the merits of Prof. March as a physician and surgeon, it is not necessary to speak. One might as well attempt to

"Paint the lilly,
Or gild refined gold."

He stands before the public as one who has successfully buffetted the storm, and who, by his own exertions, has arrived at his present enviable position. 


\section{GEORGE BUSH.}

The Rev. George Bush is professor of Hebrew in the University of New York. He affords a remarkable instance of perseverance through difficulties, being in a great measure, a self-taught man. He has long been distinguished for the extent and variety of his attainments in oriental literature, and probably as an oriental linguist, has no equal in this country. He has, says Mr. Poe, published a great deal, and his books have always the good fortune to attract attention through the civilized world. His Treatise on the Millenium, is perhaps that of his earlier compositions by which he is most extensively, as well as most favorably known. Of late days, he has created a singular commotion in the realm of theology by his Anastasis, or the Doctrine of the Resurrection: in which it is argued that the doctrine of the resurrection of the body is not sanctioned by reason or revelation. This work has been zealously attacked, and as zealously defended by the professor and his friends. A subsequent work on The Soul, by the author of Anastasis, has made nearly as much noise as the Anastasis itself.

$\mathrm{He}$ is a Mesmerist and a Swedenborgian-has lately been engaged in editing Swedenborg's works, publishing them in numbers. He converses with fervor, and often with eloquence.

$\mathrm{He}$ is one of the most amiable men in the world, universally respected and beloved. His frank, unpretending simplicity of demeanor, is especially winning.

"In person he is tall, nearly six feet, and spare, with large bones. His countenance expresses rather benevolence and profound earnestness than 
high intelligence. The eyes are piercing; the other features, in general, massive. The forehead, phrenologically, indicates causality and comparison, with deficient ideality-- the organization which induces strict logicality from insufficient premises. He walks with a slonching gait and with an air of abstraction. His dress is exceedingly plain. In respect to the arrangement about his study, he has many of the Magliabechian habits."

Professor Bush was born on the 12th of June, 1796.

While the above was in the press, the writer discovered another very interesting work by Professor Bush, in which he, it is thought, triumphantly proves that the prophecies relating to the restoration of the Jews, are to have a literal fulfilment, and that the land of hallowed memories, is yet to receive again its ancient tenants, and to yield its teeming riches to the old age of the same people, whose infancy was nurtured upon its maternal bosom; that the olive and the vine shall again spread their honors over the mountains once delectable, but now desolate; and that the corn shall yet laugh in the valleys where the prowling Bedouin pitches his tent, "Without assuming," says he, "to fix with absolute precision, the day or the year which the counsels of Providence may have assigned to the fulfilment, we are still confident that we incur no hazard in saying, that the most accurate researches in prophetic chronology, as well as the pregnant signs of the times, afford abundant warrant for the belief, that we are now just upon the borders of that sublime crisis in Providence of which the restoration of the Jews to Syria, and their ingathering into the church, is to be one of the prominent features." 
Oh! lost and loved Jerusalem !

That we on earth may stay,

To see thy glorious harvest home In thy redeeming day!

To see thy mountain cedars green, Thy valleys fresh and fair,

With summers bright as they have been, When Israel's home was there!

Thine are the wandering race that go Unbless'd through every land,

Whose blood hath stained the polar snow, And quenched the desert sand;

And thine the homeless hearts that turn

From all earth's shrines to thee,

With their lone faith for ages borne In sleepless memory.

For thrones are fallen and nations gone, Before the march of time,

And where the ocean rolled alone, Are forests in their prime;

Since Gentile ploughshares marred the brow Of Zion's holy hill-

Where are the Roman eagles now? Yet Judah wanders still.

And hath she wandered thus in vain, A pilgrim of the past?

No! long deferred her hope hath been, But it shall come at last;

For in her waste a voice I hear, As from some prophet's urn,

It bids the nations build not there, For Jacob shall return. 


\section{ZELOTIS GRINNELL,}

Was born on the 8th of April, 1797, at Cortwright, New York. His parents emigrated from Connecticut to Delaware county, in 1794, and subsequently removed to Harpersfield, where they have resided on a farm ever since. At the early age of fourteen, Zelotis obtained a hope in the Savior, and at that age was baptized by the Rev. Warren Luke. All the education his parents had been able to give him, was that of a common school, which he occasionally attended during the winter months, between the age of six and eleven years. From eleven to the age of twenty-one, he lived with his eldest brotl,er, who was a farmer, at Stamford. During that interval, Zelotis was so deplorably ignorant of book learning, that had any one ventured to foretell his future eminence as a preacher, it would have been admitted as good proof of insanity.

A few months after attaining his majority, influenced by a sense of duty to God and to man, he commenced trying to preach. Under the disadvantages which he labored, as is always the case, he had to encounter the sneers and ridicule of men of the world, who, without any agency of their own, had received a better education. "How often does a noble and gifted soul become an object of scorn and neglect, because its peculiarity and preponderating excellence is unacknowledged by surrounding persons. The ass treads down the most beautiful flower-man the most faithful brother's heart.

At the age of twenty-two, Mr. Grinnell settled on the line between Orange and Sussex counties, a broken, though an old settled country. When he commenced preaching, he was totally ignorant of the first principles of English grammar, and his 
humility would not permit him to fall into the track of a good old divine similarly situated, who, the writer was informed, on one occasion, desiring to impress his audience with the belief that he knew more than he did, expounded his text in this wise: "My hearers, godliness is the past participle of the verb God."

Mr. Grinnell had, however, from his childhood, a great taste for reading, which he gratified by borrowing books, whenever he could get them. These he would study by firelight, frequently placing his hair in jeopardy by its proximity to a dying ember. It used to be a common rernark of his father: "That 'Otis is always a borrowing books."

After settling in the ministry, he attended school for three weeks, for the purpose of gaining some knowledge of grammar. What improvement he has made since, has been by hard labor, while others slept, as he has raised a large family upon a very humble salary. But he is well aware that the growing intelligence of society, makes it more and more advisable, that the ministry should not fall below the average standard of intelligence in the community they instruct.

In 1819 , he was regularly ordained to the work of the ministry. In 1820, he married Miss Abigail Osborne, of Harpersfield; but, two years afterward, she died. He subsequently married Esther Blain, with whom he removed to Paterson, New Jersey. In 1835, his second companion died. He afterwards took a third wife, and in 1838, removed to New York city, when he became pastor of the Broome (now Cannon) Street church. In 1842, on account of his impaired health, he removed to Elmira, Chemung county, New York, where he still resides. He has thirteen children now living, six of whom have made a creditable profession of faith. His eldest son is in the senior class at Hamilton uni versity. 
Mr. Grinnell has always been a laborious worker in the ministry, having, at the lowest calculation, preached between six and seven thousand sermons. He has also had the pleasure of baptizing, on a public profession of their faith, more than seven hundred persons, seven of whom are now preaching the gospel. He is now in his fifty-second year. He has always had to contend with a delicate constitution, suffering much from "dyspepsia," that " thorn in the flesh," of so many gifted men, who suffer their professional duties to intrude upon the hours which ought to be devoted to bodily exercise.

Well might a learned physician observe: "I know not which is the most necessary to the human frame, food or motion." Were the exercise of its body attended to in a corresponding degree with that of the mind, men of great learning would be more healthy and vigorous - of more general talents -of more ample practical knowledge-happier in their domestic lives-more enterprising and attentive to their duties as men. In fine, it may with propriety be said, that the highest refinement of the mind, without improvement of the body, can never present any thing more than half a human being.

Owing to the very small amount of his surplus funds, Mr. Grinnell has had but small chance of procuring books-the need of which he has often felt. But, by adopting a resolution to lay by a certain portion of his marriage fees for this purpose, he has, in twenty years, managed to obtain about three hundred volumes.

He possesses a full, rich voice, and his personal appearance is prepossessing. Although very popular as a preacher, there is nothing of stage effect in his eloquence-no imposing attributes or gesturesno extremes of intonation. His sermons are "simple nature, the eloquence of truth, spoken in love." 
AMERICAN BIOGRAPHICAL SKETCH BOOK.

\section{WILLIAM CULLEN BRYANT,}

The "most chaste, original, nervous and elegant lyric poet of the day," was born at Cummington, Massachusetts, on the 3d of November, 1794. His father was a physician, in humble circumstances, but a man of fine literary taste. William exhibiting early indications of superior talent, was carefully instructed in the art of composition. His poetic productions, at a very early age, were numerous, and exhibited a peculiar freshness and beauty. After remaining at Williams' college two years, at his solicitation, he received an honorable dismission. He then studied law in the office of Mr. Justin Howe, and afterwards with the Hon. WV. Baylies. In 1815 he was admitted to practice, which he did at Plymouth, Nassachusetts, until 1825, when, having married, he removed to his present abode in the city of New York. He has spent a considerable time abroad with his family, visiting nearly every remarkable place in Europe. He is now the well known editor of the New York Evening Post. He has by no means, however, entirely deserted Elysium and Arcadia for the forum and the caucus room, as ever and anon, gems are still dropping from his pen.

On the 6th of May, 1847, Mrs. Sarah Bryant, the mother of our poet, and of other sons, whose merit and reputation reflect honor upon their parentage, died at Princeton, Illinois. She was born in Plymouth county, Massachusetts; a part of our country where the vigorous virtues are hereditary. Removing in early life with her parents to a remote part of her native state, she and her kindred carried with them, in their habits and principles, the elements of that high morality which distinguished their ancestry. 


\section{SAMUEL B. BRITTAN.}

The Rev. S. B. Brittan was born at Phillipston, Massachusetts, on the 13th of August, 1815. By a series of misfortunes, his father soon afterwards became embarrased in his circumstances, and at the tender age of seven years, the subject of our memoir was forced by an imperious necessity, to leave the family circle for a home among strangers. None but those who have suffered under similar circumstances, can measure the agony of a little boy on thus quitting the "warm fireside circle of love" for a dwelling where the sunshine of affection shines not, and where

When the kiss of love goes round There is no kiss for him.

Who, it has been asked, can gaze upon a young and inexperienced being thus entering upon the thorny path of life-who, with a knowledge of all that experience teaches, the disappointments, the sorrows, the anxieties, the pangs, the agonies that await mortal man upon his strange career, can watch the young lie sleeping, all unconscious of the evil to come, and not feel sad at heart to think, that in such a bitter school they must learn the great lessons that prepare for immortality!

But dry thine infant tears, and still the throbbings of thy little heart, for spirit watchers are around thee, and $\mathrm{He}$ who was once a little child like thee, will temper the wind to the shorn lamb.

At the age of fifteen Mr. Brittan was apprenticed to a carriage maker. Finding this business entirely unsuited to his taste, he, after remaining at it two years, resolved to seek a more congenial occupation. Accordingly he bid adieu to New England, and removed to Brooklyn, New York. At that place he 
was soon engaged in a business which he thought presented a more flattering prospect of success, but he soon discovered that manufacturing of any kind had no attractions for him. He felt an irresistible inclination to seek the retirement of the study, and determined, if possible, to prepare for the ministerial office. Being now about to enter upon a new sphere of thought and action, and as his advantages in early life were very limited, it became necessary at this period, to subject himself to a severe and protracted course of mental discipline. He obtained a situation as teacher in an English school, in which capacity he continued for several years, pursuing his studies in private at the same time.

In the autumn of 1840 , he was taken into fellowship as a Christian minister by the New York Association of Universalists, and in August, 1841, received ordination. At the same time he became pastor of the Universalist society at Danbury, Connecticut, where he remained until the spring of 1843 , when he accepted an invitation to the pastora] charge of the First Universalist society in Albany. On the following year, contrary to his own expectation and the unanimous desire of his people, he was led by a train of circumstances, over which he had no control, to settle in Bridgeport, Connecticut, where he remained two years. During this term, a large and intelligent society and congregation were gathered, and an elegant church edifice erected. The circumstances which had required his removal from Albany having now changed, he was, by the repeated and earnest solicitations of many friends, induced to return to that city, where, in May, 1846, he resumed his labors.

In May, 1847, at the solicitation of many who listened to them as they were originally delivered, Mr. Brittan published a volume of his discourses under the title of the "One Great Idea." He is also the author of various other interesting works. 


\section{JOHN JACOB ASTOR.}

The following account of this wonderful man, is condensed from that popular work, Beach's Book of Wealth:

John Jacob Astor is classed, by those who know him best, not only among the richest, but also among the truly great men of the world. The talent which, in another age, and in another state of society, was exercised in the art of war, is now, to a great extent, engaged in the peaceful occupations of the counting room. War has been a great field for the development of great talents. But commerce affords scope for a greater variety of talent, and is a field. on which the most gigantic genius, and the most soaring ambition may expend themselves in unlimited conquests. In this department of human action, Astor has displayed a great mind. Landing on our shores as a common steerage passenger-a poor, uneducated boy-a stranger to the language and the people-he has, by the sole aid of his own industry, accumulated a fortune scarcely second to that of any individual on the globe, and has executed projects that have become identified with the history of his country, and which will perpetuate his name to the latest age.

He was born in July, 1763, in the village of Waldorf, near Heidelberg, in the duchy of Baden, Germany. His father was a very worthy man, and held the office of bailiff. At the age of eighteen, young Astor, on the eve of leaving his home for a foreign land, resolved to be honest and industrious, and never to gamble. In March, 1784, he landed in this country, a steerage passenger, having sailed from London in November, and been detained by the ice three months. The ship in which he had 


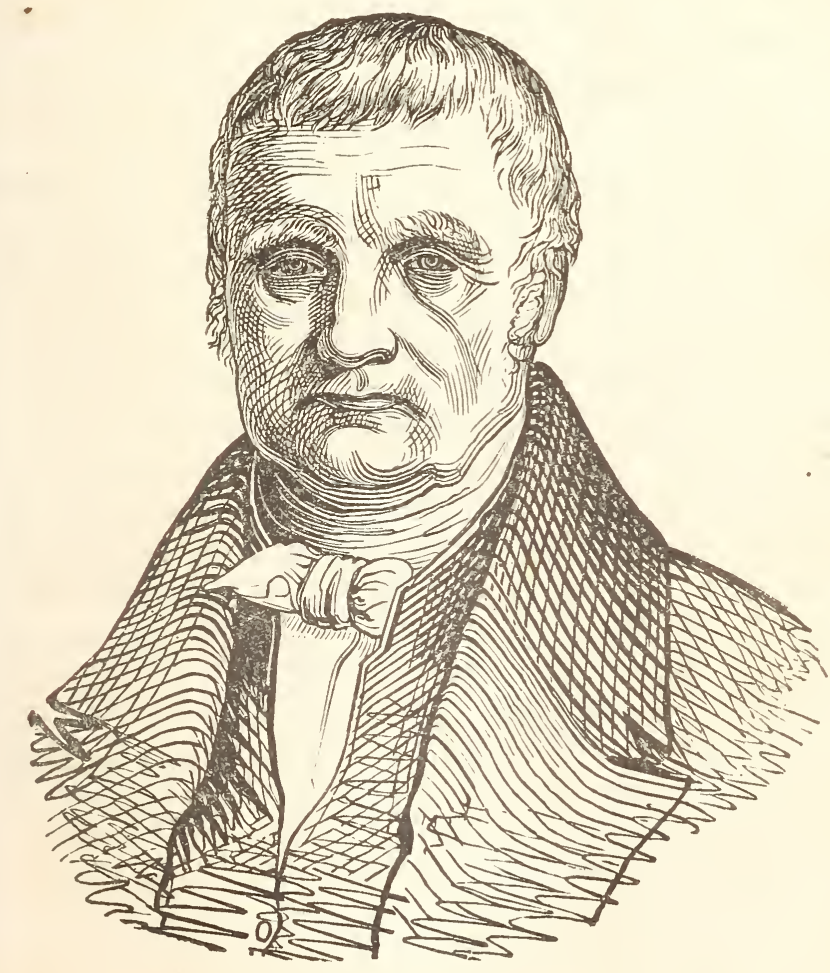

JOHN JACOBASTOR. 

taken passage was commanded by Captain Stout, father to the present president of the Eagle Insurance company. On one occasion young Astor ventured beyond the limits assigned to the steerage passengers, and appeared on the quarter-deck. Capt. Stout, observing it, came up, and in a very peremptory manner, asked him how he dared to intrude there! ordering him instantly to retire! This poor steerage passenger is now the richest individual in the western hemisphere, and can look down upon those who then held him in so much contempt. On his voyage he became acquainted with a fellow countryman of his, a furrier, who induced Mr. Astor to learn this art. The main portion of Mr. Astor's property at this time consisted of seven flutes from his brother's manufactory, at London, which, with a few other articles of merchandize, he sold, and invested the small proceeds in furs, and commenced learning the fur-trade. He was soon after engaged as clerk in the fur establishmen1 of Robert Bowne, a good old Quaker, who prized Mr. Astor very much, for his untiring industry and fidelity. Subsequently, by the aid of his brother Harry, he engaged in business for himself, associated with the late Cornelius Heyer. Afterwards he became associated with Mr. Smith, the father of Gerrit Smith. At the close of the revolutionary war, Oswego, Niagara, Detroit, and other posts, being in possession of a foreign power, a serious embarrassment was thrown in the way of the fur trade. Soon after Mr. Astor entered into the business, in 1794-5, by a treaty these posts were surrendered, when, contemplating the grand opportunity then offered to him, he said: "Now, I will make my fortune in the fur trade." His prediction was verified. Astor, with an industry and sagacity unparalleled, improved his opportunity, and after the lapse of six years, during the first year of the present century, he had amassed something like $\$ 250,000$. By the natura] 
course of accumulation, this sum, at the present time, would have amounted to $\$ 6,000,000$ - but, in Mr. Astor's hands, it has increased to more than four times that amount. Nine years later, at the age of forty-five, Mr. Astor founded the American Fur company, for the purpose of competing with the powerful British associations, which were in a fair way to monopolize the traffic in furs throughout the northern and southwestern portions of our continent.

From the time of the establishment of the American Fur company, Mr. Astor became largely engaged in commerce. His ships, freighted with furs for France, England, Germany and Russia-and with peltries, ginseng, and dollars, for China, now plowed every sea, to receive these products of the New World, and exchange them for the valuable commodities of the Old.

Mr. Astor has vast tracts of land in Missouri, Wisconsin, Iowa, and other parts of the west, the prospective value of which is very great. The greater portion of his property, however, is in real estate and mortgages in the city of New York. Could Mr. Astor's property be kept unbroken and under its present management, it would become the largest individual estate ever known on the globe. The estimates of the value of his property are variousthose knowing his affairs best, placing it at $\$ 30,000,000$ - and some as high even as $\$ 50,000$,000. His income, on a moderate estimate, must be $\$ 2,000,000$ a year, or $\$ 166,000$ a month; which is about $\$ 41,500$ a week; $\$ 5,760$ a day; $\$ 240$ an hour, and \$4 a minute. Mr. Astor has made a donation of $\$ 350,000$ for a library in the city of $\mathrm{New}$ Iork, the interest of which is to be expended in employing agents to purchase books, and in the erection of a building. Mr. Cogswell, late editor of the New York Review, is the agent and librarian. 
Mr. Astor has two sons; one of his daughters became the Countess of Rumpff, and lately deceased, at Paris; another (deceased) was married to Mr. Bristed, an Englishman, author of a work on the Resources of America, and now a clergyman of Bristol, Rhode Island.

\section{DANIEL WEBSTER.}

Near the close of the last century, in the woods of New Hampshire, might have been seen a stern looking youth, in coarse attire, shouting to a yoke of oxen, or splitting wood in the farm yard. Deprived of all the advantages of education, and shut out from the world by a dense forest, how could it have been supposed that the voice of one so lowly, would ever echo in thunder tones of soul-chaining eloquence in the halls of congress, or that his sagacious counsels in the cabinet, would entitle him to rank among the first statesmen of the world. Yet all this came to pass, and Daniel Webster, by his indomitable energy, and untiring perseverance, worked his way from the plow to the senate chamber!

Mr. Webster was born at Salisbury, New Hampshire, at the head of the Merrimack river, on the 18th of January, 1782. His father was at one period an officer of the revolution, and for many years judge of the court of common pleas. Like his son, he was a man of strongly marked character, full of decision, integrity, firmness and good sense. 


\section{CHURCHILL CALDOM CAMBRELENG,}

Was born at Washington, North Carolina, October, 1786. His grandfather was Churchill Caldom, whose father came from Scotland, and settled on the Pamlico river, about the year 1700 . His maternal grandfather was Col. John Patten, a gallant officer in the revolutionary war; and who was in the battles of Brandywine, Germantown, and Monmouth. He was made prisoner at the capitulation of Charleston, and remained on parole till the end of the war.

Mr. Cambreleng, by the death of his father, was left an orphan at an early age, and the straightened circumstances of his family, occasioned by the long absence from home of his grandfather, deprived him of the advantage of a classical education, and before the age of twelve he was compelled to leave the academy at which his first rudiments of instruction had been acquired. This deficiency, however, has since been well supplied by the native energies of a remarkably vigorous and observing mind, by self-cultivation and by extensive traveling, both at home and abroad.

In 1800 , at the age of fourteen, he was placed in the store of a merchant, with whom he remained, in New York, till 1802. The ill success which attended his present employer, caused him to return to North Carolina, in $1 \vee 05$, where he found almost all his old school companions engaged in a life of dissipation, which soon naturally attracted him within its round. After a few months, however, he broke from its spell of wild and careless pleasure, and returned to prosecute his fortunes by his unaided exertions, in New York. Unfortunately, however, for the young adventurer, he was detained a fortnight 


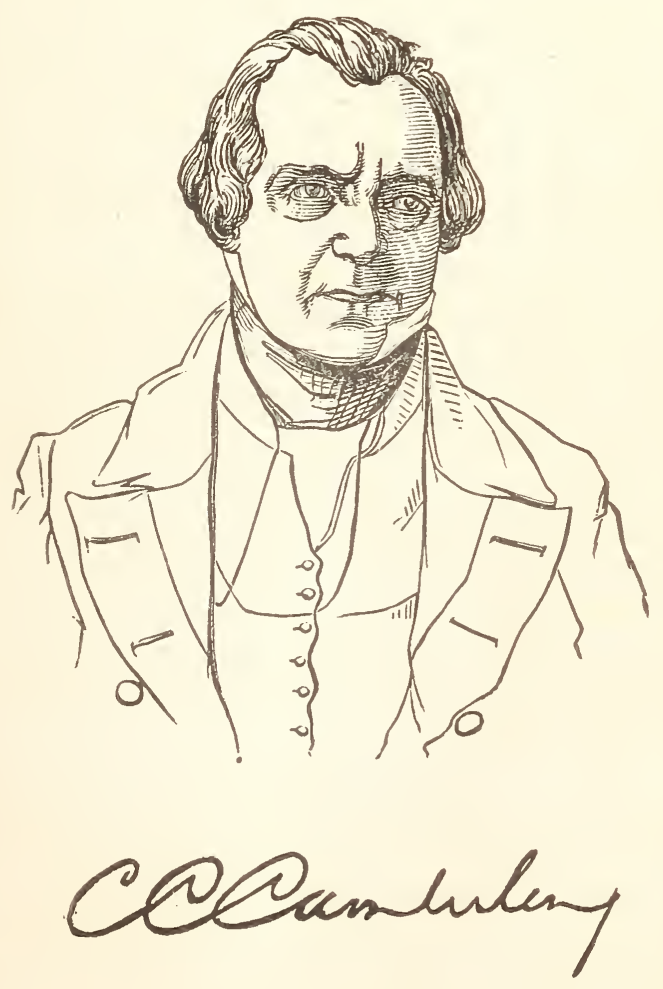



before he could embark at Ocracock kar, by the end of which time the gambling table, which was the constant place of amusement of the young men of that day and section, had despoiled him of the last penny of his little outfit, with which his mother had been able to launch him forth on the career of his fortune. On landing at New York, accident threw him in the way of a kindly and shrewd old Scotch merchant, who invited him to his house, and gave him temporary employment,' until such time as a more suitable opening in life should present itself. It was not long before, in 1806 , he was engaged as clerk by an eminent merchant named Clark, at Providence, Rhode Island, who was largely concerned in the northwest coast trade of the Pacific ocean.

At the termination of his employment at Providence, he returned again to New York, where, for several years, he was engaged as a merchant, in the commission business. This he relinquished, in 1819 , to undertake the agency of a large cotton speculation, in New Orleans, which had been projected by some enterprising merchants in the former city. The declaration of war, in June, however, defeating the speculation, he returned to New York by land, through the Indian territory, encountering many hardships, and escaping from imminent dangers. At that period commenced his connection with Mr. Astor, with whom his most important commercial transactions were had, and who, one of the most acute judges of men, always reposed an important confidence in Mr. Cambreleng, entrusting many important commissions of business to his discretion.

When the Russian mediation between the United States and Great Britain was proposed, in 1813, Mr. Astor projected a speculation to a large amount in Canton, and proposed to establish a permanent agency there, in connection with his settlement at 
the mouth of the Columbia river. Mr. Cambreleng was selected by Mr. Astor to execute this important commercial enterprise, and went to Europe to await the result of the negotiation, under the Russian mediation.

Soon after the dreadful battle of Leipsic, Mr. Cambreleng commenced his journey to Sweden, through Pomerania to Berlin, (then filled with wounded,) Potsdam, Dessau and Leipsic. From thence he followed the route of the allied army to Frankfort on the Maine, to Basle in Switzerland, and thence to within sixty miles of Paris. It was a journey full of interest and adventure, affording not only an opportunity of seeing the civilized soldiers of Europe, but the Cossack, Calmuc, Bashkin, and Tartar. He was frequently in the neighborhood of unimportant skirmishes and battles, and met occasionally bodies of prisoners returning on the snow, at the point of the bayonet, it being mid winter and the ground covered with snow. After much delay and difficulty, he with two companions reached the head quarters of the allied army at a village about fifteen miles from Troyes, but only as the army was leaving there for Bar-sur-Seine. The advanced guard of the army was engaged on the turnpike leading to Troyes, and there was much consternation among the allies, at the report that Napoleon had thrown himself into that place at the head of an army of 200,000 men. Mr. Cambreleng and his companions also started for Bar-sur-Seine, but had not only to pass over one of the terrible cross roads of France in the middle of winter, but to follow in the train of more than a thousand cannon and baggage wagons. They reached Bar-surSeine at nine o'clock at night, after having travelled the distance of nine miles in as many hours. In addition to their other troubles, they were quartered in a house with a German prince and his attendants, who had taken possession of every room, and 
all the eatables into the bargain. The travellers had to sleep in the same room as the master of the house, his wife, children and servants. The host, however, on learning that they were Americans, opened a secret closet and gave them some food, together with a bottle of Burgundy. From thence, Mr. Cambreleng reached Chatillon, where was assembled the congress of ministers, which was the object of his destination.

The negotiations for peace were delayed much longer than was anticipated, so that he was detained in Europe more than a year. His time, however, was not unemployed. He visited Sweden, Prussia, Silesia, Bohemia, Germany, Switzerland, France, Holland, and England. Despairing of an early and pacific termination of the treaty of Ghent, he returned in the Hannibal to New York in 1814. In 1815, he again visited France, Italy and Asia Minor. On his return he commenced business in New York, which after a few years terminated unsuccessfully. In 1825, he made a tour through England, Ireland, Scotland, and Wales. His life has thus been an adventurous and roving one, replete with striking incident and romantic adventure, for which, as well as for scenery, and the novelty of travel, he has always had a strong passion. Though his career was commercial, Mr. Cambreleng has always been a zealous politician, and a uniform advocate of democratic principles. He had not long been settled in New York before he took an active part in politics. In 1821, he was nominated for congress, and was elected by a large majority. The seat thus obtained, he preserved until the fall of 1838. He thus continued a member of congress for eighteen years consecutively, and the responsible stations he occupied while there, need not be enumerated.

While travelling in Europe in 1840, he was appointed minister to Russia, but after the inauguration of General Harrison in 18t1, he tendered his 
resignation. Since his return, he was elected a member of the recent convention for revising the constitution of the state of New York. He is at present residing on his beautiful farm on Long Island.

The history of Mr. Cambreleng cannot but be interesting to the young men of our country, who may believe that the want of a classical education is an indispensable bar to arriving at distinction. Had he not by the force of circumstances, been compelled to leave school at the age of twelve, the chances are a hundred to one, that his history might have been comprised in the following lines of the poet;

There was a man, was born and cried And then-what then?-he died.

\section{HENRY CLAY}

In Hanover county, Virginia, on the 12th of April, 1777, was born a boy, who, early deprived of his father, was left to buffet with the world. But this boy, by his native talent and dauntless perseverance, overcame innumerable difficulties, and steadily advanced, step by step, until his fame, as a jurist and statesman, has travelled through the world. Who could have supposed that a poor, fatherless youth, by his own efforts, would have thus risen from obscurity to be the candidate of a powerful party, for the highest station in the United States. Yet this was accomplished by Henry Clay!

For nearly half a century has his name been a "familiar word," and his history is inseparably intertwined with that of his country. 


\section{HORACE GREELEY.}

This distinguished editor of one of the most respectable, and widely circulated daily newspapers in the Union, says the American Phrenological Journal, was born at Amherst, New Hampshire, February 3,1811, and is the oldest survivor of seven children; two having died before his birth. A brother and three sisters are still living. His father and mother, who still survive, and now reside in Erie county, Pennsylania, were both born a few miles eastward of Amherst; the latter in Londonderry, of Scotch-Irish lineage (her maiden name Woodburn); the former, in that town, or Pelham, of English extraction; but both families had long been settled in that region-the Woodburns since 1723. All his ancestors, so far as there exists any remembrance, "were farmers-the Greeleys, generally, poor ones; the Woodburns, in comfortable circumstances, having been allotted a good tract of one hundred and twenty acres in the first settlement of Londonderry, which still remains in the family, the property of an uncle of the subject of this sketch, who, when not quite three years of age, was taken to spend the winter thereon, in the family of his maternal grandfather, with whom he was early a favorite. After the novelty of his visit had worn off, he was sent to the district school, a few rods off, rather to diminish the trouble of looking after him in a large family of grown persons, than in the hope of his learning any thing. But he had already been taught the alphabet, and the rapidity with which he passed from this to the first class in reading and spelling, is still a matter of vivid local remembrance, and even fabulous exaggeration. At four years of age, he could read and spell credita- 
bly; at five, he was esteemed at least equal, in those branches, to any one attending the school. He continued at his grandfather's during most of the scinool months--usually six in each year-until six years old, the school in his father's district being two miles from the family dwelling. But he evinced no such faculty for learning higher branches. Grammar, commenced at five, was not fairly comprehended until eight, nor mastered until some time later; in geography proper (the relation of places to each other) he was not proficient, though the historical and other statistics intermingled therewith were easily and rapidly assimilated; penmanship utterly defied all his exertions; and it was only when he came, some years later, to take up the elemental arithmetic of the common schools, that he found himself able to press forward with his infantile celerity. He could not remember the time when he had not the multiplication table at command, and all the processes of school arithmetic seemed but obvious applications of, or deductioñs from, this. But his school days in summer ended with his seventh year, and in winter with his fourteenth; being much interrupted at earlier periods by the necessities of a life of poverty and labor. He never enjoyed the benefits of a day's teaching in any other than a rural common school, generally of two to four months each winter and summer, and these very far inferior to the schools of the present day, even in the least favored sections of New York or New England.

When not quite ten years of age, his father lost his little property in New Hampshire, and removed to Westhaven, Vermont, near the head of Lake Champlain, where he remained nearly six years. The first two were employed in land-clearing, on contract, with the aid of his two sons; the next, in a saw mill, while the boys worked on a small, poor farm; the residue, in clearing, and farming upon 
shares. During these, as before, our subject was favored with the loan of books and periodicals, by neighbors of ampler resources, and, devoted very much of his spare time to reading, especially in the winter evenings, when the labors of the long days of summer, which so severely tax the sinews of a youth of ten or twelve years, had been succeeded by shorter days and lighter tasks.

At eleven years of age he made his first attempt, at Whitehall, New York, to find employment as an apprentice to the printing business, which he had previously decided to follow as a vocation, but was rejected on account of his youth. Afterward, he could with difficulty be spared. When fifteen, however, his father found himself enabled to make a long meditated tour of observation westward, with a view to the removal of his family; and now the eldest son was permitted to gratify the cherished desire of his heart, by entering, on the 18th of April, 1826, as an apprentice, the printing office of the Northern Spectator, at East Poultney, Rutland county, Vermont. Here he remained more than four years, until late in June, 1830, when the paper was discontinued. Meantime, his father and family had removed, in the fall of 1826 , to Wayne, Erie county, Pennsylvania, where he visited them in 1827, and 1829, and whither he repaired, on quitting Poultney, in 1830. Working by spells on their rude wilderness farm, and, when opportunity offered, at his trade, in Jamestown and Lodi, New York, and in Erie, Pennsylvania, he remained in that region a little more than a year, finally quitting it, when work ran out, about the first of August, 1831, for New York, where he arrived on the 16th of that month, and has ever since resided. He worked as a journeyman during the first year and a half of his stay, with some unavoidable interruptions, through want of employment, until early in 1833, when, in connection with another young printer, he pur- 
chased materials, and undertook the printing of a cheap daily newspaper, for a man who failed soon afterward. Other printing was soon procured, less promising, but better paid. His first partner was suddenly taken away by drowning, in July; another took his place. The concern was moderately prosperous; and in the following spring, March 22, 1834, our subject issued, without subscribers, and almost without friends, in a city where he was hardly known beyond the circle of his boarding house and his small business, the first number of The New Yorker, a weekly journal, devoted to popular literature, and an impartial summary of transpiring events. That paper was continued through seven years and a half, having a circulation which rose, at one time, to over nine thousand. It averaged more than five thousand throughout, but was never pecuniarily profitable, owing, in good part, to bad management in the publishing department. In September, 1841 , it was merged in the weekly issue of The New York Tribune, started as a daily on the 10th of April, in that year, and still continued under his editorial management.

He was married in July, 1836, to Mary Y. Cheney, of Litchfield, Connecticut. They have had four children, of whom only the third survives. Our subject renounced the use of intoxicating beverages in his fourteenth year, and of tea and coffe in his twenty-seventh. In his twenty-ninth he became an advocate of those ideas of social reörganization, or comprehensive renovation of society and industry, known among their advocates as Association, and by their opponents as Fourierism, to which his energies are still devoted, so far as the unremitting duties devolving on the editor of a political daily will permit. He is now, of course, in his thirtyeighth year, slender in frame and stooping in gait, and, in spite of the incessant cares and unseasonable labors of his vocation, enjoys average health. 


\section{EDWIN CROSWELL.}

The family of Croswell came from Great Britain, previous to the revolution. The Rev. Andrew Croswell, whose sermons are preserved in print, came over early in the eighteenth century. Caleb Croswell, the paternal grandfather of the subject of this sketch, was born at Charlestown, Massachusetts; and the spot on which the Charlestown convent was built, and subsequently burned, near Boston, was once in possession of the family.

Caleb resided near Hartford, in the state of Connecticut, and married there. The issue were five sons and two daughters. The sons, Thomas O'Hara, Mackay, Caleb, Harry, and Archibald, removed to this state about the year 1790. They all established themselves at Catskill, on the Hudson. The eldest, Dr. Thos. O'H. Croswell, continued in the practice of his profession until his death, in 1844, greatly beloved by the community among whom he had passed the greater part of his life. He held the office of postmaster of that place, by the common consent and desire of the inhabitants, from the organization of the office, under a commission from Gen. Washington, to the period of his death. Mackay commenced the publication of the Catskill Packet, in 1792, then the only paper, except one at Ponghkeepsie, between the cities of New York and Albany, and one of the six or seven that had then an existence in the state. He retired in 1820 , and died in 1847. Caleb died in 1803, in Connecticut, on the same night that the mother of Edwin Croswell expired at Catskill. Harry, now the Rev. Dr. Croswell, established the Balance, at Hudson, a paper of high excellence and wide circulation, and distinguished for its avit and cleverness. 
He removed to Albany in 1809, and after conducting a paper there for three years, retired from the field of politics, fitted for the ministry, took orders, and, for the last thirty-five years, has discharged, with eminent fidelity and ability, as an ambassador of Christ, the duties of rector of Trinity church, in New Haven, Connecticut. His sons, now living, are the Rev. Wm. Croswell, rector of the Church of the Advent; Sherman Croswell, associate editor and proprietor of the Albany Argus; and Frederick Croswell, now in business in New Haven, Connecticut, and before the people of that state as the democratic candidate for comptroller. Archibald, the youngest of the five sons of Caleb Croswell, is a resident of Schoharie county, and for many years has been engaged in extensive manufacturing pursuits there.

Edwin Croswell, the subject of this sketch, the eldest son of Mackay Croswell, was born at an eventful era in the political world, 1798. His maternal grandmother was a Shethar, a New England matron, imbued with all the spirit of the revolution, under whose charge he was placed after the death of his mother. Her eldest son, Capt. John Shethar, was an officer in the active service of his country, and received the approval and confidence of Gen. Washington during the whole of that war. His academic instruction was under the charge of the late Rev. Dr. Reed, and he pursued classical studies under the Rev. J. M. Peck, but never entered college. His first efforts for the newspaper press, were in his fourteenth year, during the first year of the war of 1812, in favor of which he, at that early age, took an active part, encouraged to act, not only by his father, but by his friend and guide, the late Moses I. Cantine, brother-in-law of Mr. Van Buren. Before he was of legal age, he entered upon the editorial charge, with his father, of the Catskill Recorder, a journal which had vigorously sustained 
the war, and subsequently the principles and measures of the democratic party, and had attained considerable celebrity and a wide circulation. In January, 1823, he was invited, on the death of Judge Cantine, to the editorial charge of the Albany Argus, and was at once, and nearly unanimously, appointed state printer, with Isaac Q. Leake. He declined, however, to take an interest in the establishment, and gave his services for the benefit of the widow of Judge Cantine. In 1824, Mr. Leake retired from the concern, and Mr. Croswell was appointed state printer, being associated with the late O. R. Van Benthuysen in the ownership of the paper, and in the public printing. In that year he married Catharine, eldest daughter of John Adams, Esq., of Catskill, counsellor at law, and representative from the Greene and Delaware district, in the twenty-third congress. Prior to the retirement of Mr. Van Benthuysen, Sherman Croswell, a capable writer, and one of the best reporters in this country, was associated in the management of the paper. In 1840, the change of parties resulted in the removal of Mr. Croswell. In 18t3, on the restoration of the ascendancy of the democratic party, he was reëlected state printer, and under the act of 1846, continues in official charge of the state paper.

Appointed at the age of twenty-five, state printer, and having, for the last twenty-four years, conducted the leading organ of the dominant party in the state of New York, with distinguished ability and vigor, Mr. Croswell has justly acquired high prominence of position as a writer and politician. For tact, sagacity, resources, experience, and all the qualities which go to constitute a party leader, Mr. Croswell has few, if any, superiors in the United States, as the almost uninterrupted series of democratic triumphs which have marked the history of parties in New York, incontestibly prove. What- 
ever may be the differences of political views, it is conceded on all hands that the Albany Argus has sustained, under his charge, during all the last quarter of a century, a high reputation for talent and for political influence. Of that famous ideal or real body known as the "Albany Regency," he is the only survivor resident in that city-most of his colleagues, indeed, except Gov. Marcy, now the distinguished secretary of war, and the Hon. B. F. Butler, district-attorney for the southern district of New York, being dead, or having gone into retirement.

Mr. Hammond, in his "Political History of New York," in 1840, speaks of Mr. Croswell, as follows:

"As a political party editor, he has few, if any, superiors in the United States. His paper has been, as perhaps it ought to have been, considering the position he occupied in relation to the democratic party, uniformly the organ of the principles and views of the majority of that party. Always cool, self-collected, sagacions and cautious, he has seldom, if ever, allowed himself to be guilty of any indiscretions; and, generally courteous.in his language, he has never attacked individuals unless their public and political conduct rendered them fair subjects of animadversion. His style of writing is more highly polished than that of most of the American newspaper editors. Indeed, it is somewhat remarkable, that a man educated to practical and business pursuits, should have acquired so accurate and nice a literary taste, and so correct a style and manner of writing. Let his future political fate be what it may, his reputation as a newspaper editor of tact and talent, will always stand high-perhaps as high, at any rate on the score of tact, as any editor in the United States, excepting only Joseph Gales." 



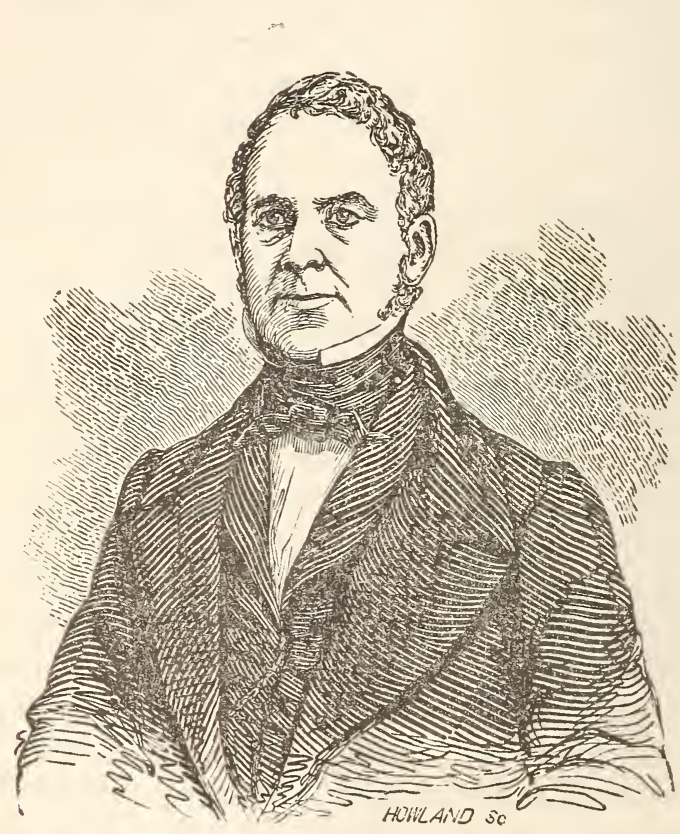

MOSES Y. BEACH. 
AMERICAN BIOGRAPHICAL SKETCH BOOK.

\section{MOSES Y. BEACH.}

The life of Mr. Beach, well known as the proprietor of The New York Sun, the pioneer of the penny press, while it presents no remarkable variety of changes or incidents, is attractive as tracing the steps of a determined man-one whose cheek never blanched in the darkest hour of adversity. The grandfather of Mr. B. was one of the small band of hardy settlers whose axes first made the woods resound on the spot where the beautiful village of Wallingford, Connecticut, now stands. The place received its name from one of their number, and when the father of our subject was a stripling of ten years old, in 1780, it could boast of only half a dozen $\log$ huts. Moses Beach (the grawdfather) lived to a good old age, ranking among the highest and most wealthy men in the settlement, and when the desert gave place to the thriving village, he answered the call of nature, resigning his possessions to his eldest son, Moses Sperry Beach, with whom fortune played some pranks, reducing a large patrimony to mere independence. Moses Sperry married Lncretia Yale, a niece of the celebrated Elihu Yale, founder of Yale college, and governor of the English East India company; but, though her connexions were all exceedingly wealthy, their "riches took wings" and went to parts untraceable. Of this couple, Moses Yale Beach, the subject of this memoir was the first born, that event occurring January 7th, 1800. When about six years old, himself and one brother and sister, four and five years his juniors, were left without the care of a mother by the hand of death, and as their father's business called him to Ohio, they were most of the time confided to the attentions of a step-mother. Moses 
was soon taught to do little chores, and at ten years old had the big ones on his hands too. At that time he did all the out door work, including the care of the horses and cattle, besides going daily nearly two miles to school, and yet found leisure time to exercise his mechanical ingenuity in the manufacture of play things for himself, his brother and sister, and for swapping with his school fellows. From four o'clock in the morning, until eleven at night, he was generally up and doing. At the age of fourteen, he was, at his own solicitation, bound an apprentice to a cabinet maker at Hartford, Connecticut. His industry excited the attention of his master, who was a close man, but who finally made a bargain with him, by which he was allowed two cents per hour for extra work. Mr. B. says he never was more overjoyed at success in any thing, than when that bargain was made. Early and late he worked, and the pennies began to count, until finally he made a bargain for the balance of his time, after he should attain his eighteenth year. For his freedom at that time, he was to give $\$ 400$. The arrangement gave him new life, and when the time came around, he had saved between $\$ 100$ and $\$ 200$, in addition, with which to commence life. He then removed to Northampton, Massachusetts, where, after working some time as a journeyman, he entered into business with another young man, named Loveland. The cabinet work of Beach \& Loveland was among the very best in the country-in testimony of which they received the first premium of the Franklin Institute-THE SUM of FIVE DoLLARs. While thus employed, under a fair sky, Mr. Beach married Nancy, daughter of Thomas and Mary Day, both direct descendants of the puritans, the latter of the Brewster family. His smooth sailing was soon interrupted by a storm, and after a long and obstinate resistance, his bark capsized. Separating from his partner, he immediately removed to Spring- 
field, and, after repeated endeavors, he established himself in a fair business. Building a convenient residence with his first means, he settled himself at his fireside, with a young and already numerous family around him. His spirits and his ingenuity returned, and ere long he was almost entirely engrossed in the manufacture of a "gun-powder engine," for propelling balloons. In this he was partially successful; but finding, from his model, that the weight of an engine of the requisite power was insurmountable, and seeing that his business was suffering, from the want of proper care, he abandoned the project. He acted too late. Again he found himself in deep water. But, matching his strength against the current, he was finally successful in obtaining a new stand. Once more he plied his ingenuity, and this time produced a rag cutting machine, an article since adopted in every paper mill in the Union, if not in the world. The saving of labor in its use is enormous; but, like other inventors, generally, he failed to derive benefit from it. A paper maker in whose confidence he relied, made use of the ideas he suggested, to combat his originality, so soon as it was presented, the result of which was beneficial to neither party. Mr. Beach, however, removed to Ulster, or Saugerties, on the North river, where he became interested, with others, in an extensive paper mill. The rag cutter, and a new drying machine, were introduced, and for several years their efforts were crowned with the greatest possible success. Mr. Beach invested some in real estate, and erected a very pretty residence, devoting his time, night and day, almost exclusively to the interests of the concern. Six years passed thus, and the seventh brought changes and adversity again. The whole of his real estate and household furniture was sold to meet the demands of the cre ditors of the mill; and in 1835, he removed with his family to New York, where he shortly after pur. 
chased the interest of Mr. Wisner in The Sun, on credit, for $\$ 5,200$. In this he was attended by unexpected success, and, paying off the demands of Mr. W. in the course of the next year, he bargained with his partner, Mr. Day, for the remaining half interest, for $\$ 19,500$. The first six months after he became entire owner of The Sun, it proved not so profitable as he had calculated upon, and he offered nearly all of his then property to have the bargain revoked; but not succeeding in that, he pushed on, and the tide turned. His principal competitor, The Transcript, gave up the field, and in less than two years from the purchase, the last dollar due for the establishment was paid up, and Mr. Beach once more could call himself independent. His career, since 1838, has been steadily upward-his ability and enterprize in the management of his newspaper have been proverbial, and, as a consequence, he has excited the malice of the envious, who found in him, from his public station, a mark at which they might send their venomous darts with impunity. But, with all this, there are very few, if any, who know him personally, and do not value him highly as a friend.

His family, having suffered some diminution, now consists of one daughter and five sons, the latter of whom are all engaged with their father, some of them being also associated with him in business. Notwithstanding his severe loss, by the unwarrantable closing up by the legislature of a banking institution, in which he was the principal stockholder, he is now reputed to be worth two or three hundred thousand dollars, besides a newspaper establishment, free of incumbrance. The daily circulation of their paper is almost incredible-50,000 copies per day-and the combined weekly issue from the establishment is not less than 400,000 sheets-a fruitful source for the accumulation of wealth. 


\section{JAMES FENNIMORE COOPER.}

This gifted writer, who has thrown a lustre around the American name, which no time nor circumstanees can diminish, was born in Burlington county, New Jersey, on the 15th of September, 1789. His family is one of the most ancient in the country, and can be traced back distinctly, to the early part of the seventeenth century. By the maternal side, his American pedigree is equally ancient, springing from a Swedish stock, which dates from the first settlement of Delaware. At a very early period, his classical education, under a private tutor, was commenced; and, at the age of ten, on the arrival of his father, Judge Cooper, at Cooperstown, where he had purchased a large estate, Fennimore was placed under the care of the Rev. Mr. Ellison, of Albany. He entered Yale college, in 1802, where he remained until 1805; when he obtained a warrant as a midshipman of the navy. After six years afloat, during which time "he gave brilliant promise of future excellence," he resigned his office for other and less turbulent engagements. On the 1st of January, 1811, he married Niss De Lancey, a sister of the present bishop of the western 'diocese of New York. After spending several years in different parts of Europe, he has now settled down upon his estate at Cooperstown. Of his writings, it is scarcely necessary to speak. Who has not lingered with delight o'er his thrilling narratives? and whose perceptions of the beautiful in nature, are not refined and strengthened by his delightful descriptions? 


\section{ELIJAH WARD,}

Is a near relative of Gen. Aaron Ward. He was born at Sing Sing, Westchester county, New York, on the 15th of September, 1816. He is the son of Israel Ward, now deceased, who married a daughter of the late John Rossell, of the same county. Mr. Israel Ward died in 18:0, when his son Elijah was just entering upon his fifth year, leaving but a scanty inheritance to his family. Young Ward was early sent to the village academy, where, pursuing only the ordinary English studies, he continued until his twelfth year. At that period he entered the store of Mr. Amos Dunning, a merchant of Sing Sing, in the capacity of clerk. He remained there for five years, during which time, without the assistance of a preceptor, he pursued a course of general reading and study. His employer was strongly attached to him, and their parting was a source of mutual regret.

In the spring of 1833 , with a firm resolution to rise by his own efforts, he removed to the city of New York. He was there employed as a clerk, by Messrs. Kibbin \& Nicholls, jobbing merchants. He continued with them until the dissolution of the firm, in 1837, and subsequently with Mr. Kibbin alone. By these gentlemen, his business talents and amiable disposition were highly appreciated, and by their aid he became thoroughly conversant with mercantile transactions-a knowledge highly valuable to one who contemplated the practice of law. He also, during that period, by husbanding his spare minutes, became a good Latin scholar.

In $1834, \mathrm{Mr}$. Ward became a member of the Literary association, an institution numbering among its members many young men now holding promi- 


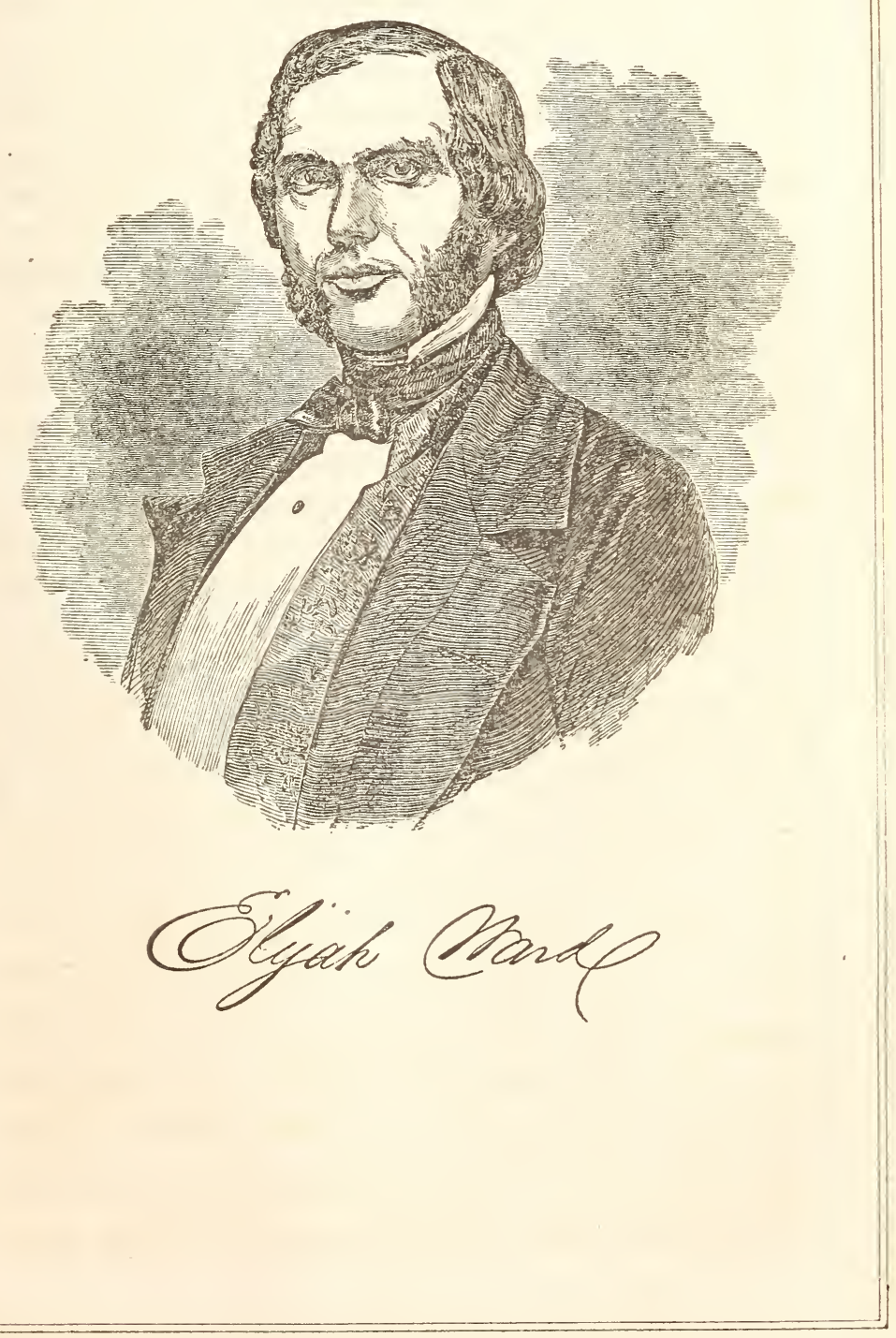



nent positions in the national legislature. In 1835 , he- was elected vice-president, and subsequently acted as president of the association. In 18:37, he delivered the opening address before the Eclectic fraternity, of which body he was corresponding secretary. It was a highly creditable production. In 1838, while still a clerk, he attended the law school, at the New York university. In January, 1839, after a hotly contested election, he was, by acclamation, elected vice-president of the New York Mercantile Library association. When it is considered, that at that time there were over 5000 members of this institution, many of whom were anxious for the office, the election of young Ward affords strong evidence of the estimation in which he was held. In the June following, on the resignation of Mr. Winthrop, he was chosen president of the association. In December, 1839, owing to his contemplated change of business, to the regret of his numerous friends, he declined the offer of a renomination. His published annual report, upon his retirement from that office, secured him the reputation of an able writer.

In February, 1840, he entered, as a law student, the office of the Hon. W. W. Campbell, of New York city. In May, 1843, after the usual examination, he was admitted to practice in the supreme court. He then became the law partner of Mr. Campbell, and continued as such until January, 1847.

We believe Mr. Ward is a democrat; but, zealously pursuing his legal studies, he has wisely and profitably steered clear of politics. He has neither sought nor desired political advancement. On the contrary, he has repeatedly resisted the wishes of his friends on that point; believing, and justly too, that the bar, of itself, affords a sufficiently ample field for distinction.

In the management of the important cases en- 
trusted to him, Mr. Ward has exhibited ability of no common order; and, should his life be spared, we will venture to prophecy that he will rank among the highest of his profession.

Possessing a fine literary taste, he has, as a relaxation from severer duties, contributed many interesting articles for the periodicals of the day, and which have received high commendation. Did our limits permit, we would gladly enumerate them. We will conclude by observing, that the success of Mr. Ward affords an additional illustration of the advantages resulting from self-reliance, industry and perseverance

\section{DAVID HALE,}

Was born at Lisbon, Newent society, near Norwich Connecticut, on the 25th of April, 1791. Nathan Hale, a native of Coventry, in that state, an uncle, was an officer in the American revolution, and graduated at Yale College, in 1773. In the war he commanded a company in Col. Knowlton's regiment, and was with the army in the retreat from Long Island, in 1776. Washington, having applied to Knowlton for a discreet and enterprizing officer to penetrate the enemy's camp, Hale was named, and readily volunteered for that dangerous service. He passed in disguise to the British camp, but on his return was apprehended and carried before Lord Howe, by whom he was ordered for execution the next morning. He was denied a Bible and the aid of a clergyman! The letters, full of fortitude and resignation, which he had written to his mother and sister, were destroyed. He was hung, 


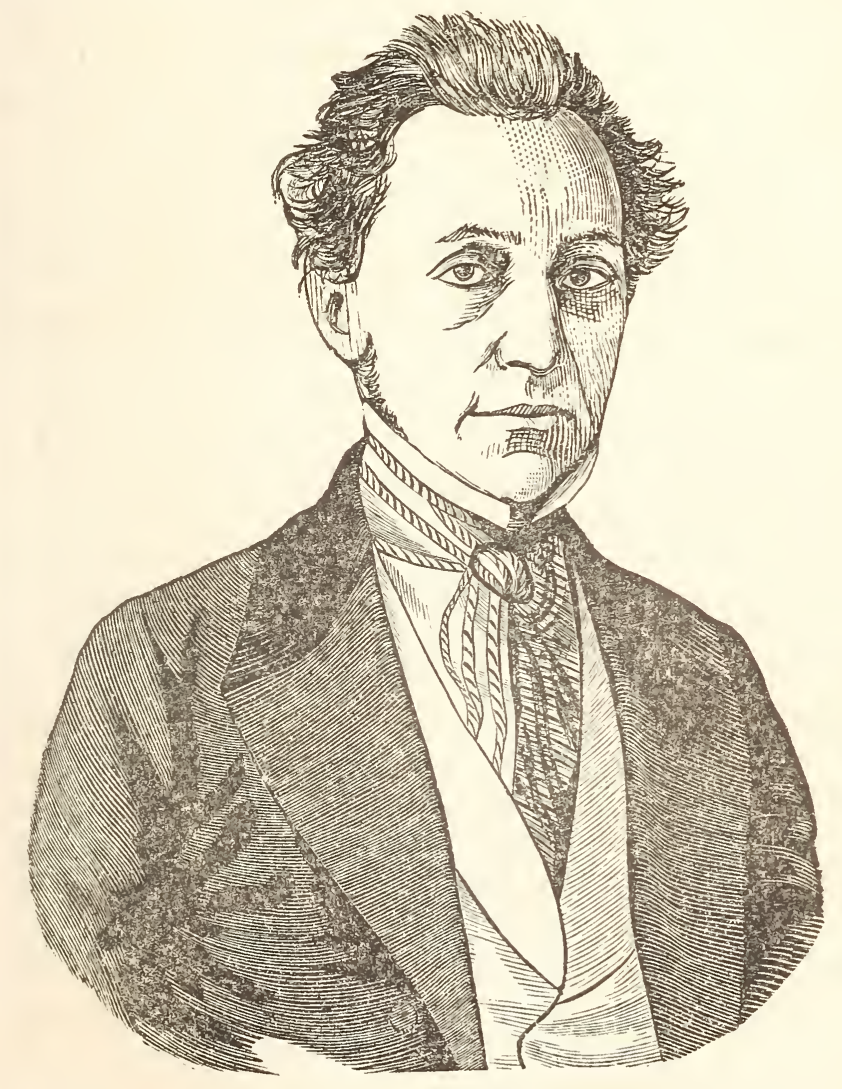

DAVID HALE. 

regretting that he had but one life to lose for his country.

The father of the subject of our sketch, was the pastor of the church at Lisbon; but, owing to ill health, when his son was thirteen years old, he removed to Coventry, where he purchased the paternal estate.

In $1 \varangle 09$, David went to Boston, where he became a merchant's apprentice. His untiring industry, punctuality, and strict integrity, soon won him the regard of his employer, who reposed unlimited confidence in him. At the expiration of his term of service, Mr. Hale commenced business on his own account.

On several occasions, he wrote for the newspapers, on the subject of theatres, and against permanent funds for the support of religious and literary enterprizes. The vigorous style, and close reasoning, displayed in those essays, attracted much attention, and caused considerable discussion, through the columns of the press, in various parts of the Union.

Arthur Tappan, having determined on establishing the New York Journal of Commerce, wrote to Boston, for a "business editor;" and the essays of Mr. Hale were the cause of an application being made to him, which he accepted. Messrs. Hale \& IIalleck are now the proprietors of that highly respectable paper, which, perhaps, ranks as high as any in the United States.

Mr. Hale is, it is said, very wealthy, having acquired the whole of his property by patient industry. He is emphatically a working man. 


\section{JOHN QUINCY ADAMS.}

See that aged man, verging upon four score, with a countenance glowing with enthusiasm, expounding the constitution before the assembled wisdom of the nation! The frail tenement of that body is near the point of dissolution, but the fires of the soul are still burning with undimmed brilliancy. Venerable patriarch! connecting a past age of mighty events with the present, when will the last leaf be shaken from the flower-stem of thy life!

John Quincy Adams was born on the 11th of July, 1767. At the age of eleven he was at school at Paris, where he received the paternal care of Franklin. In 1780, he was placed in the public school at Amsterdam, and afterwards in the University of Leyden. At the age of fourteen, lie went as private secretary with Mr. Dean, then minister to Russia. In his eighteenth year, he returned to the United States, and in 1787 he received his degree of bachelor of arts, at Harvard University. Having studied law, and been admitted to the bar, he removed to Boston, where he was for four years engaged in the business of his profession. It was here that he wrote several of his best essays. He was subsequently selected by Washington, to be the American minister to the Netherlands; and from 1794 to 1801 , he was employed in diplomatic services. "One of the last official acts of Washington, was to appoint him minister to Portugal; but his destination was changed to Berlin, by his father, who had just succeeded to the presidency." On his return to the United States, he was elected to the national senate. In June, 1805, he was chosen professor of rhetoric and oratory in Harvard university. President Madison appointed him as minister to 


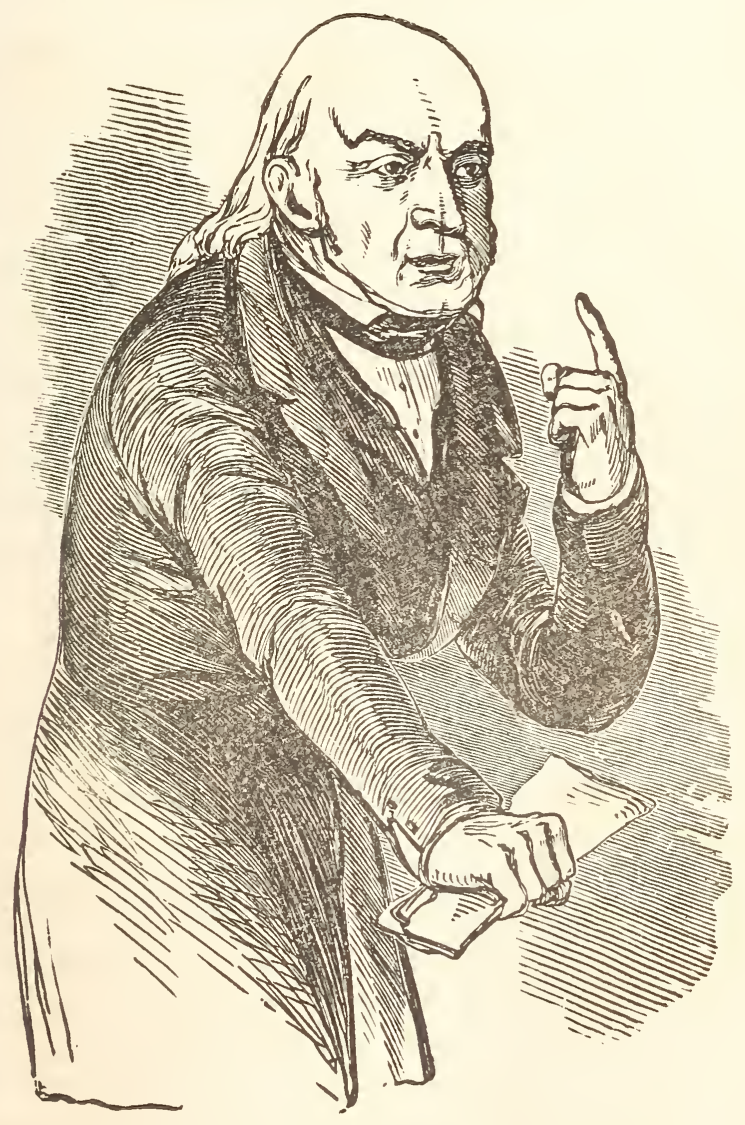

JOHN QUINCY ADAMS. 

Russia, from whence he was transferred to Ghent, with Messrs. Clay, Gallatin, and Bayard, to negotiate a peace between the United States and Great Britain. He was afterwards appointed minister to England, where he remained until Mr. Munro's accession to the presidency, by whom he was recalled to be secretary of state. After being eight years at the head of the cabinet, Mr. Adams was elected president of the United States. His presidential term expired in 1829, when for a brief period he retired to his native town of Quincy. In 1831 , he was elected to the house of Representatives, of which body he has ever since been a membernever, during that long period, having been absent from his seat a single day, except from sickness. For nearly three score years has he kept a diary, which, it is presumed, embraces one of the best histories of the country that could possibly be written.

\section{JACOB RIDGWAY.}

The late Jacob Ridgway, of Philadelphia, was born in 1768. He was, in every sense of the word, a self-made man. In early life, he was a journeyman ship-carpenter. He was subsequently American consul at Antwerp. He also resided for some time at Paris. The latter portion of his life was spent in Philadelphia, where he was a most useful citizen, being constantly engaged in enterprizes which gave employment to hundreds of mechanics. He built upwards of a hundred houses, and died worth at least six millions of dollars. Unlike many great capitalists, he never oppressed the poor laborer, nor was his fortune cemented by the heart-drops of the orphan and the widow. 


\section{ORVILLE DEWEY.}

The Rev. Orville Dewey, D. D., one of the most celebrated ministers of the Unitarian church, was born at Sheffield, Berkshire county, Massachusetts, on the 28th of March, 1794. He graduated at Williams' college, and studied theology at Andover Theological seminary. The first ten years of his professional life were spent at Bedford, Massachusetts, and the last ten principally in the city of New York, where he still labors as pastor of the Church of the Messiah. As a proof of the estimation in which his talents were held, it may be stated that on one occasion, during the temporary absence of the late Doctor Channing in Europe, Mr. Dewey, by request, occupied his pulpit.

The reputation of Mr. Dewey as an author, is already so firmly established, that an elaborate criticism, either of his manner or style, would be a work of supererogation, and indeed, in the writer, one of much presumption. It will be sufficient to say, that his discourses abound in the purest and most exalted precepts, beautifully adapted to almost every condition of life, and replete with instruction, such as becomes the minister who himself feels that the religion he preaches is divine.

His compositions are in no danger of being classed with those of a certain reverend gentleman, who having inadvertently preached one of his sermons for the third time, one of his parishioners having noticed it, said to him after service, "Doctor, the sermon you preached us this morning having had three several readings, I move that it now be passed."

The following extract from a sermon on "Human Greatness," which the writer heard Mr. Dewey 
deliver at Washington city, in 1847, and in which allusion was made to many scenes during his travels abroad, will enable the reader to form some idea of his style.

"I have seen the magnificence of all ceremonial in worship; and this was the thought (the grandeur of penitence) that struck me then. Permit me to describe the scene, and to express the thonght that arose in my mind, as I gazed upon it. It was in the great cathedral church of the world; and it brings a kind of religious impression over my mind, to recall its awfulness and majesty. Above, far above me, rose a dome, gilded, and covered with mosaic pictures, and vast as the Pantheon of old Rome; the pillars which supported it were as large as many of our churches; and the entire mass lifted to five times the height of this building; its own height swelling far beyond; no dome so sublime, but that of heaven, was ever spread before mortal eye. And lo! again stretching away into dimness and obscurity, arches beyond arches, fretted with gold, and touched with the rays of the morning sun. Around me, a wilderness of marble! with colors as variegated and rich as our autumnal woods; columns, pillars, altars, tombs, statues, pictures, set in ever during stone; objects to strike the beholder with never ceasing wonder. And on this mighty pavement stood a multitude of many thousands; and through bright lines of soldiery, stretching far down the majestic aisle, slowly advanced a solemn and stately procession, clothed with purple, and crimson, and white, and blazing with rubies and diamonds. Slowly it advanced amidst kneeling crowds and strains of heavenly music; and so it compassed about the altar of God, to perform the great commemorative rite of Christ's resurrection. Expect from me no sectarian deprecation; it was a goodly rite, and fitly performed. But amidst solemn utterances and lowly prostrations, and pealing an- 
thems and rising incense, and all the surrounding magnificence of the scene, shall I tell you what was my thought-' One sigh of contrition, one tear of repentance, one humble prayer to God, though breathed in a crypt of the darkest catacomb, is worth all the splendors of this gorgeous ceremunial, and this glorious temple."

\section{JOSEPH STORY.}

This eminent jurist was born at Marblehead, Massachusetts, on the 18th of September, 1779. He graduated at Harvard college, and immediately afterwards commenced the study of the law. At the age of twenty-two he commenced the practice of his profession at Salem. Such was his high reputation, that three years afterwards he was elect. ed a member of the Massachusetts legislature, in which body he remained several years, serving a considerable portion of the time as speaker.

In 1809 he was elected a member of congress. In 1811, at the age of thirty-two, Mr. Story was appointed to fill the vacancy on the bench of the United States Supreme court, occasioned by the death of Judge Cushing. There is no previous instance, either in this country or in England, of so young a man being elevated to so high a judicial position. This office he held until the close of his life. He was probably one of the most industrious men of his age. He died at Cambridge, Massachusetts, on the 10th of September, 1845, in the sixtyeighth year of his age. 


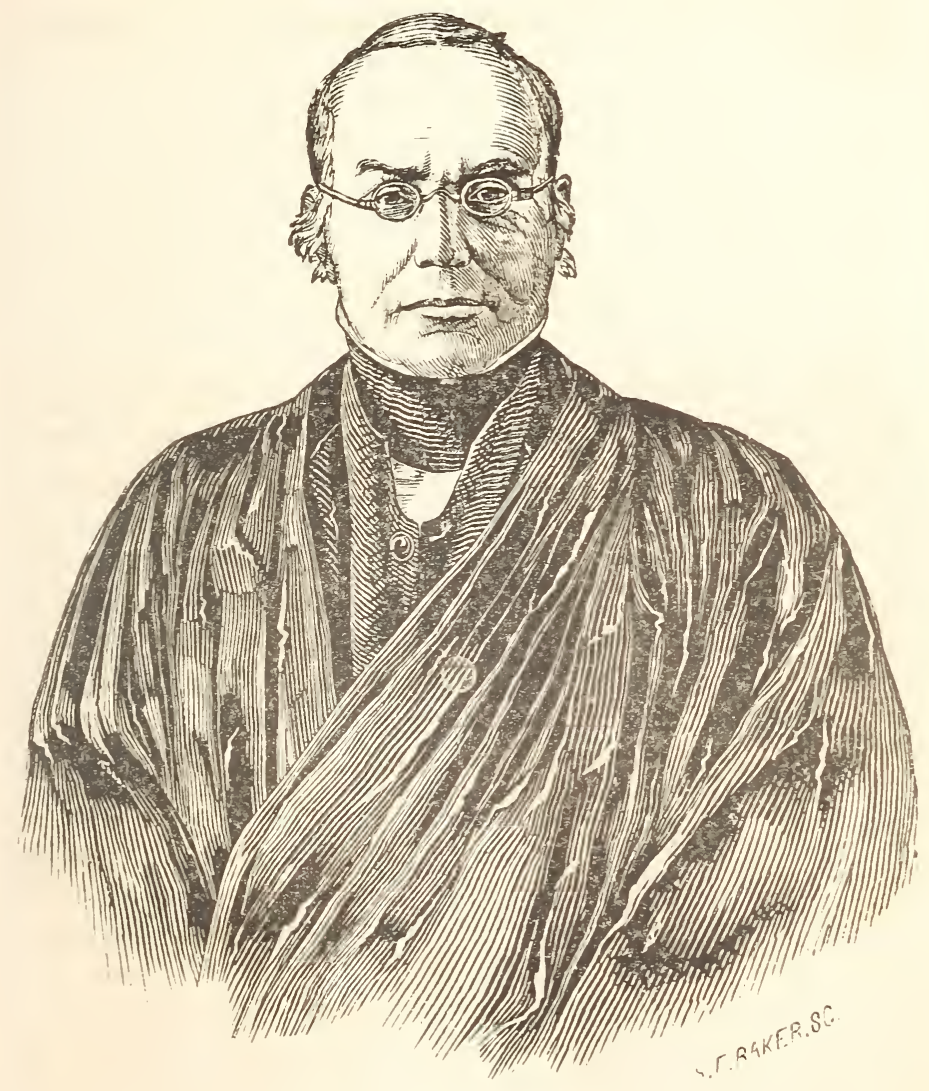

JOSEPH STORY. 

AMERICAN BIOGRAPHICAL SKETCH BOOK.

\section{GEN. ORRIN GRIFFIN.}

It has been beautifully said, that patriotism loves the pure air of the country. Her chosen home is the fresh hill side, and from the clear breeze of the mountain, she draws her aliment. By bubbling brooks, by verdant lawns, and in the quiet contentment of pastoral life, she rests undisturbed by the wearying bustle and changing scenes of metropolitan existence.

Gen. Griffin, whose life has suggested the above remarks, was born in the town of Stamford, Delaware county, New York, on the 14th of February, 1804. This region of country is undoubtedly one of the most beautiful in the state, and the strong and vigorous intellects which it has sent forth to the battle field and to the senate, are not few. Here is the fountain of the Delaware, and its silver waters wind musically through the glen, with solemn murmurings "as though many spirits were whispering about man."

Until the age of nineteen, he worked upon the farm. He then spent four years in teaching. At the expiration of that time, he embarked in the mercantile business at Hobart, in his native county, and where he still continues to reside.

In 1826 he was elected to the office of ensign in the eighty-seventh regiment of infantry. Having held all the intermediate offices, he was, on the 7 th of April, 1837, elected brigadier-general of the twenty-fifth brigade of infantry, including seven different commissions in eleven years.

Of his capacity as a military man, it is scarcely necessary to speak. A strict disciplinarian, and an enthusiastic lover of military science, he always retained the good will of those under his command. 
In 1842 he took his seat in the state legislature. While there, as chairman of the military committee, he brought in a bill to amend the military law of the state, a reform in which had so long been desired. Among the amendments proposed, and which has since become a law, was one to furnish the uniform companies with arms from the state arsenal. In an eloquent and pointed speech, he urged the propriety of this distribution, on the ground that the arms had been purchased under an appropriation of congress in $1 \triangleleft 07$, for the purpose of arming the militia of the United States. His bill, although attacked by the political journals of both parties at Albany, passed the house by a handsome majority, but it was not reached by the senate.

General Griffin was one of the few who voted to sustain the speaker of the house in his decision, declaring the appropriation of money for the geological survey of the state, required a two-third vote, inasmuch as the bill making the appropriation, provided for the distribution of a part of the books among private individuals. The wisdom of this decision has been acknowledged by subsequent legislation.

In 1844, General Griffin was a delegate to the Baltimore convention from the state of New York, and he voted for James K. Polk.

During the unfortunate anti-rent troubles in 1845, in Delaware and the adjoining counties, General Griffin, on many occasions at the imminent peril of his life, took an active part in leading bodies of men, for the suppression of the riotous proceedings of the misguided "Indians," which resulted in the death of Sheriff Steele. He, like many others, was in favor of applying a legislative remedy for the grievances complained of, although he could not sanction resistance to the authorities.

Gen. Griffin is a respectable scholar. He is tall, and possesses a vigorous frame combined with an impulsive temperament. He is married. 


\section{SHEPHERD KNAPP,}

Was born in the town of Cummington, Hampshire county, Massachusetts, on the 7th of January, 1795. His father, Jonathan Knapp, and mother, Perses Melvin, were natives of Massachusetts. The former, descended from the puritans, was born in Plymouth county, and moved thence to Cummington, shortly after the revolutionary struggle, in which he bore an active part, and continued to reside there until his death. As an honest and industrious farmer, he was much respected, and the duties of husband, father, neighbor and Christian, he discharged with fidelity and zeal. He died at a good old age, beloved by all who knew him. Perses, his wife, was originally from Concord, near Boston, her American ancestors having emigrated to this country from Scotland.

Shepherd Knapp, the subject of this sketch, was the fifth son. His early years were spent on the farm, discharging such duties as children usually perform. His education was confined to the usual elementary branches, and as in the case of many other New England boys, it was acquired during the winter months, his time and labor being deemed too valuable to be spared from the farm at any other period.

In the spring of 1812, at the age of seventeen, he came to the city of New York, where he entered the counting house of the late Gideon Lee, who formerly resided at Worthington, a town adjoining Cummington, and to whom the family of Mr. Knapp were well known. He continued with Mr. Lee, as clerk, until the spring of 1819 , when he was taken by the latter into partnership. During his clerkship he had, by industry and frugality, ac- 
cumulated a considerable sum of money. In addition to this, he had, by his devotion to business, acquired a character for sagacity and ability, of far greater value than his little store of wealth.

In the spring of 1-20, Mr. Knapp was married to Miss Catharine Louisa Kumbel, daughter of William Kumbel, a native of Niemried, Germany, who emigrated to New York before the war of the revolution, and where his descendants still continue to reside.

After his marriage, Mr. Knapp continued to devote himself zealously to his business, and knowing that "minutes are the gold dust of time," every" hour had its appropriate duties. By the strict observance of the rules which he adopted, he was now rapidly accumulating a fortune.

The first act of his life which brought him prominently before the public, was the responsible part he took in the celebrated conspiracy trials in New York, in 1825. As a director of the Tradesman's bank, owing to certain suspicious movements, Mr. Knapp, in conjunction with Mr. Lee, his partner, and the late Elisha King, applied to the chancellor for an injunction against the bank, restraining the newly elected directors from making any more loans or discounts. This was a bold proceeding, and an assumption of great responsibility. In a few days, however, the wisdom and necessity of the measure became apparent. The particulars of the astounding disclosures which followed, the explosion of the Life and Fire Insurance company, with other institutions similarly situated, involving in ruin and disgrace hundreds of prominent citizens, and the prosecutions which followed, may be found in the papers of the day.

In $1832, \mathrm{Mr}$. Knapp was appointed by the board of directors of the United States bank, director in their branch bank in the city of New York-he being chosen as the representative of the hide and 
leather interest. He continued to discharge the duties of that station, until within a brief period of the winding up of the affairs of that institution.

In 1837, Mr. Knapp was elected to the honorable position of president of the General Society of Mechanics and Tradesmen of the City of New York, one of the most useful and influential societies of the state. In 1838, he was elected president of the Mechanics' Banking association, a new institution, just going into operation. He had, however, scarcely taken his seat at the board, when he was. invited to the presidency of the Mechanics' bank, then vacated by the death of the late Jacob Lorillard, who had a short time before been unanimously chosen, in a moment of great peril to the bank, to undertake its extrication from embarrassment. While Mr. Lorillard was engaged in that laborious and vexatioús task, his health failed, and he survived but a few weeks, his death being caused by his great mental and physical exertions, on behalf of the bank. Mr. Knapp, succeeding to this post of labor and responsibility, successfully carried out what his predecessor had begun. The credit of the bank was revived, its usefulness restored, and, with Mr. Knapp still at its head, it ranks among the first in credit, influence and popular favor.

On the withdrawal of Mr. Lee, in the spring of 1839, Mr. Knapp, although a much younger man, also retired from active business, declining to continue the house alone. He and his partner had made the bulk of their estate together, had always lived on the most intimate and confidential terms, and so continued up to the period of Mr. Lee's death.

Mr. Knapp takes an active part in many of the public institutions of the city and state, in savings' banks, rail road and insurance companies. In the benevolent institutions of the city, he is most untiring and devoted, and with his means, have 
grown his charities. The elements of Mr. Knapp's character, spring from that source of all virtue"truth without affectation." Not boasting of profound learning, and without pretension to any thing he does not possess, he has, by energy and perseverance, risen to eminence and distinction. He is known and honored, for the kindness of his heart, liberality and devotion to the interests of the city and state; in addition to which, he possesses a sound judgment, and a large share of that valuable quality, so useful to the community, "common sense."

\section{ANTHONY BARCLAY}

The annexed engraving was executed for this work, under the impression that the distinguished individual whom it represents, was an American citizen. This is an error, as he does not yet enjoy that honor. His portrait will; however, recall to many, recollections of the very courteous treatment they have received at his hands, during their official intercourse with him as British consul. He is, in the full sense of the word, an English gentleman. Although extremely tenacious of the rights of the country whose interests he represents, perhaps no man admires more ardently the peculiar beauty of American institutions.

Mr. Barclay continues to reside in New York city; and his office being in Barclay street, has probably led to the erroneous statement that his ancestors were American, and that the street was named from them. 


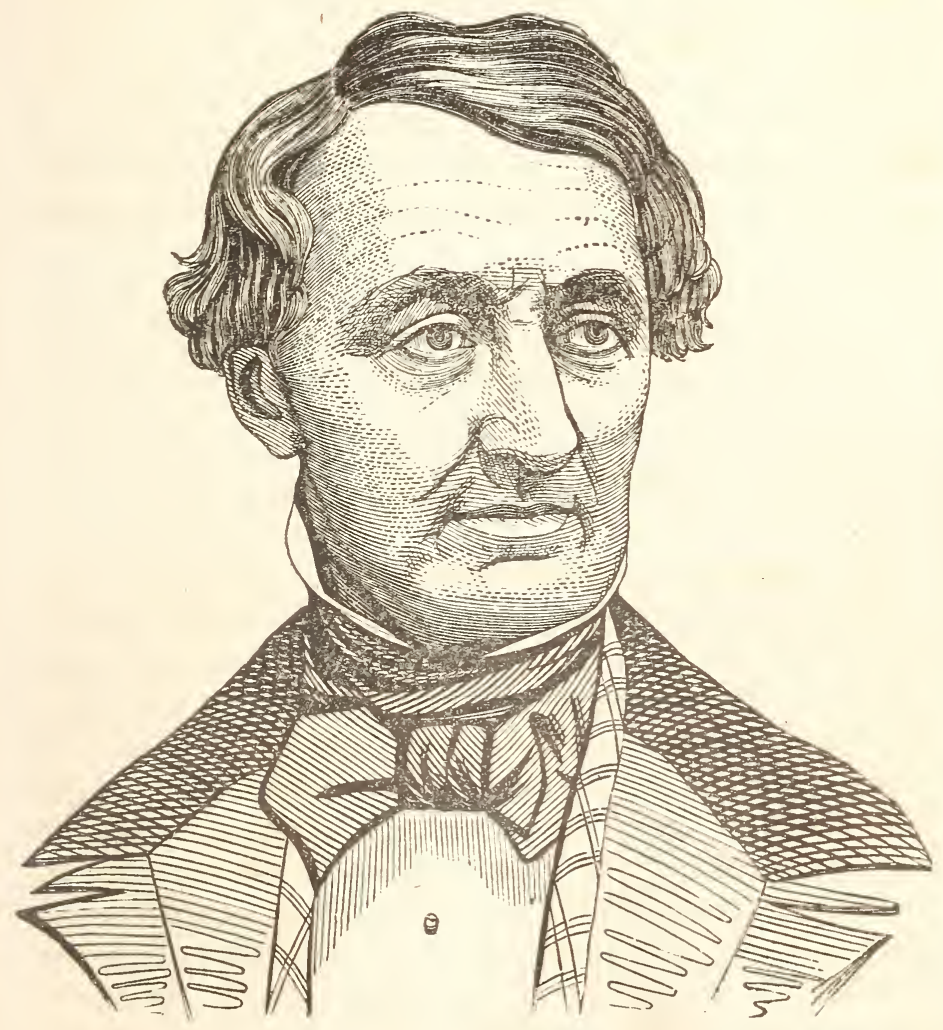

ANTHONY BARCLAY. 



\section{JAMES BROOKS.}

Hard the labor, small the gain,

Is there in making bread from brain.

"Stand, O man! upon the hill top-in the stillness of the evening hour-and gaze upon the glorious world around thee! See, where the mists, soft and dim, rise over the green meadows, through which the rivulet steals its way! See where, broadest and stillest, the wave expands to the full smile of the setting sun-and the willow that trembles on the breeze-and the oak that stands firm in the storm, are reflected back, peaceful both, from the clear glass of the tides! See, where, begirt by the gold of the harvests, and backed by the pomp of a thousand groves - the roofs of the town, bask, noiseless in the calm glow of the sky. Not a sound from those abodes floats in discord to thine ear-only from the church tower, soaring high above the rest, perhaps, faintly heard through the stillness, swelis the note of the holy bell. Along the mead low skims the swallow-on the wave, the silver circlet, breaking into spray, shows the sport of the fish. See, the earth, how serene, though all eloquent of activity and life! See the heavens, how benign, though dark clouds, by yon mountain, blend the purple with the gold!" How beautiful! But see that keen, earnest-looking man, in the fourth story of a dingy building, with a pile of newspapers,piled around upon his desk! While the glorious sun is rolling on his golden course, and the wind is wafting onward the winged ship, like an eagle, over the ocean, nature lying in gorgeous and most superb scenery, this man sits straining his eyes to search out food for the public mind. He is a slave, for he is an editor! 
James Brooks, one of the most eminent, and the most industrious writers of the present day, was born at Portland, Maine, in 1811. His father, who commanded a privateer during the last war with England, was lost, with his vessel, at sea, when the subject of this sketch was about four years of age. Hence, like many other self-taught men, he was thrown upon the world at a period when the majority of youths first enter school. With an energy which nothing could damp, and a perseverance seldom equalled, he conquered difficulties by attempting them, and soon acquired a stock of knowledge which few other men, similarly situated, have ever attained.

Having previously edited several other papers, Mr. Brooks, with his brother, in 1836, started the New York Express; which paper, in conjunction with Mr. Townsend, the business editor, he still conducts.

In 1841, Mr. Brooks married Miss Mary Ran dolph, of Virginia.

"Brooks's Letters from Europe," in 1835, published in the Portland Advertiser, and copied into every paper in the Union, would of themselves place his name among the very front rank of writers. He was, in 1837, the competitor of Albert Smith, of Maine, for a seat in congress. We believe it was a tie vote, and on the second trial, the editorial duties of Mr. Brooks detaining him in New York, while his competitor was in the field during the whole canvass, the latter was victorious.

Mr. Brooks was recently elected a member of the New York legislature. 



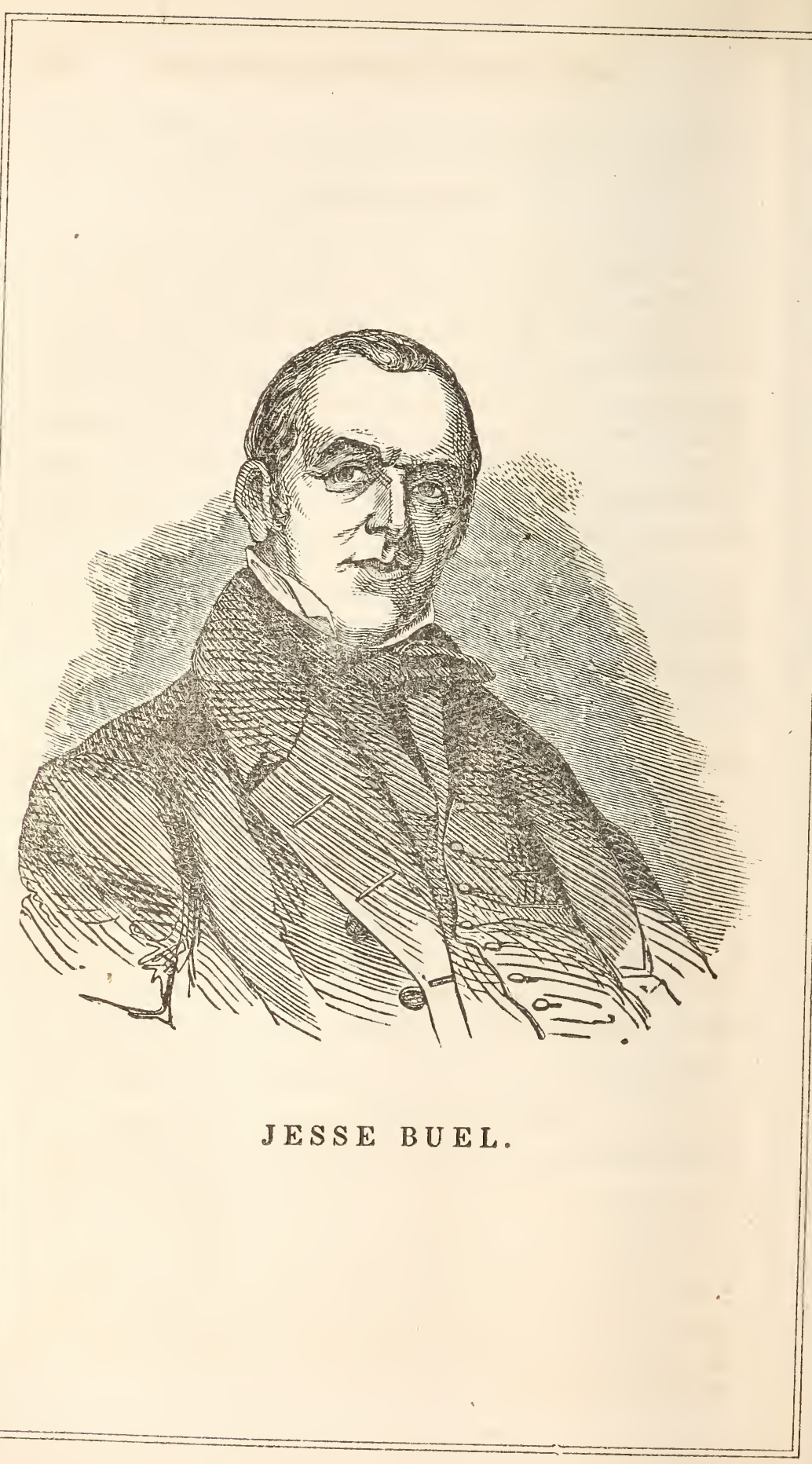




\section{JESSE BUEL.}

The late Judge Buel was born at Coventry, Connecticut, on the 4th of January, 1778. Being the youngest of a family of fourteen children, he enjoyed few facilities for early education, never having had, during his entire life, more than six months' schooling. He was brought up a printer, and passed a large portion of his active and useful life in superintending the publication of various newspapers, commencing with the editing of the Troy Budget, and closing with that of the Albany Cultivator. It is, however, the agricultural labors and example of Judge Buel, that have rendered his life the common property of mankind.

In the year 1821 he purchased a farm of eightyfive acres near the city of Albany, which then formed a part of what was appropriately termed the "Sandy Barrens." That part now called the "Albany Nursery," then lay an open common, unimproved, covered with bushes, and apparently doomed to everlasting sterility. These unpromising appearances which, to a common mind would have presented insuperable obstacles, seemed to increase the efforts, rather than damp the ardor of Judge Buel. Difficulties and obstructions were with him every day familiars. His mind had been, in some measure, formed under their influence. He recognized and acted on the doctrine, that where God has done little, it is incumbent on man to do much; and that nothing in this world is ever lost, by courting situations requiring the expenditure of effort. As a practical commentary on the truth of his doctrine, it is worthy of remark, that the same acre of land which in 1821 he purchased for thirty dollars, he left at his death, in October, 1839, worth two hundred dollars. 
The efforts of Judge Buel have greatly tended to render honorable, as well as profitable and improving, the pursuits of agriculture. He taught men that agricultural prosperity resulted neither from habit nor chance; that success was subject to the same law in this, as in other departments of industry, and before it could be secured must be deserved; that mind, intellectual power, and moral purpose, constituted as essential parts, in the elements of agricultural prosperity, as in those of any other; and all these truths he enforced by precept, and illustrated by practice. By these means he has called into the field of agricultural labor a higher order of mind; has elevated the standard of agricultural attainments; and has tended to render this extensive department of industry as intelligent, respected, and honorable, as it ever has been conceded to be useful, healthy, and independent.

The writings of Judge Buel are principally to be found in the many addresses he has delivered; in the six volumes of his Cultivator; in the small volume published by the Harpers of New York; and in his last work, the "Farmer's Companion," published by the Massachusetts Board of Education, and intended for the use of common schools.

Judge Buel died at Danbury, Connecticut, on the 4th of October, 1839, of an attack of the bilious fever. He was on his way to Norwich and New Haven, to deliver addresses to the agricultural and horticultural societies of those places. He died in the very field of his labors; in the midst of his usefulness; in the full maturity of his mental faculties.

The publication of the Cultivator is continued at Albany by Luther Tucker, Esq., a gentleman of great energy of character, and eminently qualified for such a work. Its circulation is immense, as neither pains nor expense are spared to secure valuable information. Mr. Tucker has a beautiful country seat at Mount Hope near Albany. 


AMERICAN BIOGRAPHICAL SKETCH BOOK.

\section{MALBONE WATSON.}

When Mason was preparing the case of E. K. Avery, and had examined about two hundred witnesses, somebody called to see him. The legal gentleman sent word that he was occupied, and could not be interrupted. "But the man is a witness-a methodist minister."

"Call him up," said Mason. "Well, sir, what can you testify?"

"I have had a vision-two angels have appeared to me, and told me that Brother Avery is innocent-

"Let them be summoned," said Mason, as he resumed his work.

Had the learned subject of this memoir been in the place of Mason, it is certain that he would have returned a similar answer; for Judge Watson is one of the few men, who come at once to the point, and who, in professional business, say nothing, unless they have something relevent to say.

Judge Watson was born in the town of Rensselaerville, Albany county, on the 27th of August, 1804. He is the son of Wheeler and Sarah Watson, who emigrated from the State of Rhode Island, to said county, as some of its first settlers, while it was yet'a wilderness. His father was of New England's best stock, one of nature's noblemen, whose sterling character for honesty was so well appreciated by his fellow citizens, that after holding for a long period, many honorable offices, he was elected to represent Rensselaer county in the New York legislature. Although a mechanic, such was his fondness for reading, that he was familiar with almost every principle in Blackstone, and to him his son may be somewhat indebted for the present 
proud position which he holds, as one of the justices of the supreme court.

Malbone early exhibited an aptness for learning, and, even in the common schools of the district, bore of all the honors off his class. He prepared for college at Greenville academy, Greene county, and graduated at Union college, in February, 1822, being not quite eighteen years of age. He immediately afterwards commenced the study of law, in the office of Henry Stone, Esq., of Rensselaerville, and completed his studies with Messrs. Foot \& Edwards, of the city of Albany. In May, 1825, not having attained his twenty-first year, he was admitted to the bar. He commenced practice in Windham, Greene county, New York, where, although an entire stranger, and a mere boy, he almost immediately entered upon a lucrative practice. After remaining there for three years, and practising for about the same period in the adjacent town of Durham, he removed to Catskill, the place of his present residence. Here, although his competitors were some of the ablest lawyers of the staté, he soon stood at the head of the bar. He was almost immediately appointed district-attorney of Greene county, and during the term of six years which he officiated, only four prisoners tried by him were ever acquitted, although in the liberal spirit for which he is so distinguished, he never from professional pride, pushed the conviction of a prisoner, unless he believed him guilty. Would that there were many such! It was repeatedly said of him, that "no man ever performed the duties of that office more liberally, or with less fear of giving offence. Finding its laborious duties to interfere with his other professional duties, although strongly urged by the judges to continue, he resigned.

In 1838, Gov. Marcy appointed him surrogate of the county of Greene. He was reappointed by Gov. Bouck, in 1842. This office he held, with credit to 
himself, and with satisfaction to the county, until his election, in June, 1847, under the new constitution, to the office of a justice of the supreme court of the state of New York. This honorable and highly responsible office, was never solicited or sought by him; but when nominated by his friends, and no man has stronger ones, finding a deep and well matured scheme on foot to defeat him, through the treachery of pretended political friends, and which would have discouraged a man of less ener$\mathrm{gy}_{3}$ he encountered and beat them. His election, under these circumstances, is considered as one of the proudest triumphs in the political history of New York. There could not have been a stronger proof of his popularity. With a disposition naturally ardent, Justice Watson has mingled deeply in politics. With a quickness of perception seldom surpassed, prompt, energetic, and generous in the extreme, he has secured a host of ardent and devoted friends. Few men are better qualified for the bench, and although his career in that position has been short, he has given proof of the possession of powers, which must eventually place him in the very front rank of American jurists.

Imitating the example of Chief Justice Marshal, whose favorite amusement during his leisure hours, was the pitching of quoits, Justice Watson, unlike many others, is too wise to neglect physical exercise. Whenever able to snatch a short respite from his professional labors, he has, with his dog and gun, struck into the deep forests and mountain solitudes of the Catskills, where, with an almost unerring aim, he would "snap a judgment" against many an unfortunate deer, and not unfrequently obtain "a verdict, with heavy damages," against a bear.

On one occasion, about two years since, during one of these excursions, in Sullivan county, he stood with his double-barreled fowling piece heavi- 
ly loaded with buck shot, waiting for a deer which his dogs had started. Suddenly hearing the leaves rustle near him, he elevated his gun, but instead of the expected deer, he beheld a huge bear, making towards him. To this proceeding, however, the judge immediately filed a " bill of exceptions," in the shape of a load of buck shot. The bear, indicating symptoms of a "demurrer," the contents of the remaining barrel were "deposited" with him for safe keeping, " and other purposes," whereupon bruin exhibited no signs of Swartwouting, but fell down, uttering the most discordant yells. We believe the skin of the bear is now used by his victor as a sleigh robe. In this and other instances, the natural coolness and intrepidity of the judge alone saved his life.

Judge Watson was, some years since, married to a lady of great worth, and he has several children, of whom he has every reason to be proud. A sister of his is the wife of the Hon. Zadock Pratt.

The residence of the judge is on the heights at Catskill, and commands a view of surpassing beauty.

Judge Watson is one of the fortunate few, whose peculiar temperament invariably leads them to look upon the bright side of things, and who, with the poet, can exclaim:

There are times when the storm-gust may rattle around, There are spots where the poison-shrub grows;

Yet are there not hours when nought else can be found, But the south wind, the sunshine, and rose?

Talk who will of the world as a desert of thrall, There is bloom, there is light in the waste;

Though the chalice of life hath its acid and gall, There are honey-drops too for the taste. 


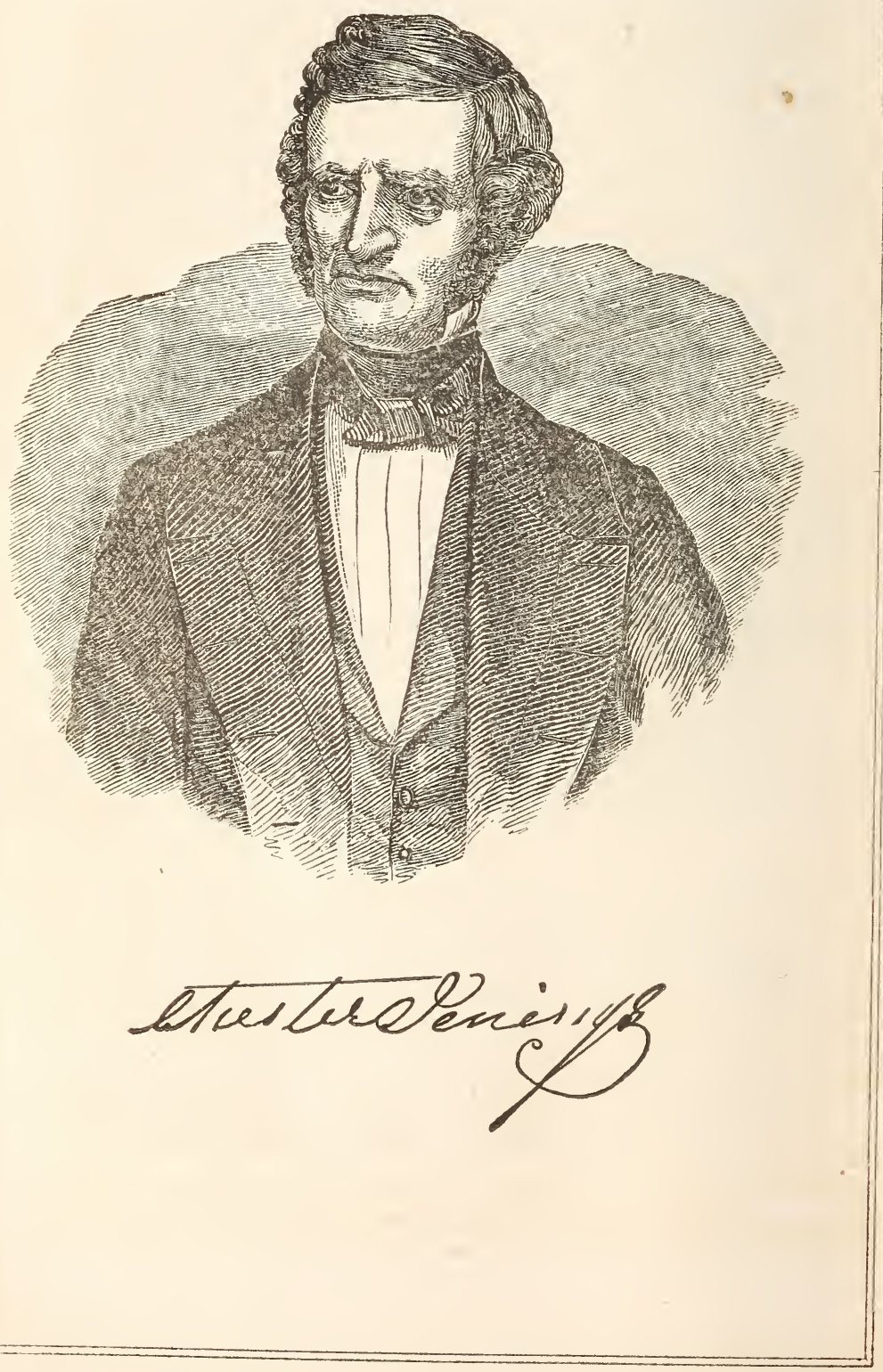




\section{CHESTER JENINGS.}

Chester Jenings was born in the town of Ellington, Connecticut, on the 19th of March, 1791. His father; John Jenings, was a native of the same place. His ancestors, who were connected with the early settlement of the country, were from England. His mother, the daughter of C. Lyon, Esq., of Greenfield, was a woman of great energy of character, and remarkable perseverance. After his father's death, his mother early instilled into the mind of her son, principles of economy and prudence, which were the surest guarantees of his subsequent success in life. How powerful is the influence of a mother! What impressions can be more strong and more lasting, than those thus received upon the mind in the freshness and susceptibility of youth! Being obliged to depend upon his own resources, and having cheerfully undertaken the support of his widowed parent and sisters, his first earnings were devoted to the purchase of a comfortable place of residence for them; and with the same filial regard did he devote himself to the happiness of his mother to the day of her death. What a beautiful moral spectacle does this afford! Says a learned writer, "I defy you to show me a son that discharged his duty to his parents, who ever permanently failed in the honest and laudable pursuits of life;" and we have the assurance of a higher authority, that he who honoreth his father and mother, shall, by no means, go unrewarded.

After being engaged in various avocations, $\mathrm{Mr}$. Jenings, in 1813, found his way to New York city, where he was employed by Solomon Gibson, Esq. It was at this period that he attracted the attention. 
and won the friendship of Ezra Weeks, Esq., who was then owner of the City hotel. On the retirement of Mr. Gibson in 1817, Mr. Jenings, under the patronage of Mr. Weeks, took a lease of the hotel, which he successfully kept for nineteen years, sustaining its well earned reputation as one of the most respectable hotels in the United States.

In the spring of 1836 , on account of his declining health, he retired from a post, the duties of which he had so well discharged. He then visited England, and in the fall of the succeeding year went to the West Indies, where he passed the winter, enjoying the balmy climate of Santa Cruz, St. Thomas, Porto Rico, and Cuba. In the spring of 1837, he returned to New York, much invigorated. 'In the ensuing fall he visited France, Italy, Austria, Prussia, Switzerland, Belgium, Holland, England, Ireland, and Scotland. Having availed himself of the best medical advice in those countries, he, after an absence of eighteen months, returned to his native land with his health completely restored. During his European tour he gained many warm friends, not less by his kindness of heart, than by his suavity and intelligence.

By the failure of the United States bank in 1840, he sustained heavy losses, but with a well balanced mind he did not spend time in useless regrets. $\mathrm{He}$ returned to his old occupation, the City hotel having been closed for some time, where he was welcomed by a large circle of old friends, and where he still remains.

Mr. Jenings furnishes a striking example of what may be accomplished by untiring perseverance, with unity of purpose. In person he is about the medium height. His forehead is good, and he has an intelligent eye. As a host he is ever attentive, and as a friend, warm, generous, and confiding. In his dealings with the world, he is noted for sound 
judgment and benevolence, and to those who know him best, it has often been felt

That e'en his failings lean to virtue's side.

Nóte.-The City Hotel in Broadway, suys Grant Thorburn, was built in the summer and autumn of 1794, and is the first house in the city, and also. in America, whose roof was covered with slates. Having set up the timbers for the roof, and nailed the rough planks whereon to lay the slates, they came to a dead stand for lack of nails to fasten on the slates. Every hardware store in the city was ransacked in vain, as prior to this no slates had been used on the continent; therefore no one imported any of the nails. There were nailmakers in New York and Philadelphia enough, but they could only make shingle nails. There is a certain art in forming the head of the slate-nail, which only nailmakers from Europe are up to.

In this dilemma they applied to me, who at that time was hammering ten-penny nails at No. 55 Liberty street.

I think it was twenty-five years after the hotel was finished, that happening to pass that way, I observed the slaters stripping the roof, preparatory to raising the building another story. I climbed up stairs, got on the roof, and gathered a handful of my nails, which I put in a bottle, pouring wine and oil among them to keep them from rust; and they are now as fresh as the hand that made them fifty years ago. 


\section{BENJAMIN B. FRENCH,}

Was born in Chester, Rockingham county, New Hampshire, on the 4th day of September, 1800. He was the son of Daniel and Mercy French. His mother's maiden name was Brown. She was the daughter of Benjamin Brown, of Chester,-and sister of Francis Brown, an eminent divine, who, at the time of his death, in 1821, was president of Dartmouth college.

Mr. French was the only child of his mother, who died when he was eighteen months old. His father was a lawyer, of high standing, and was for several years attorney-general of the state of New Hampshire.

The subject of this biography recieived a good common school and academic education, and it was the earnest desire of his father, and friends, that he should enter college, which he declined to do. And although it was the intention of his father that he should be educated for the bar, Benjamin, having a taste for mechanics, opposed this intention, with a view of being either a mechanic or a mariner; and so much was his heart set upon one or other of these employments for a livelihood, that, in 1819, he went to Boston, with a view of going to sea. Disappointed in obtaining a berth on board a ship, he enlisted as a soldier in the army of the United States, and was stationed at Fort Warren, on Governor's island, in the harbor of Boston, with a detachment of the eighth regiment of infantry. He was, soon after enlisting, appointed a sergeant, and performed his duty faithfully, for about four months, when, at the earnest solicitation of his friends, who provided a substitute, he left the army on the 12th day of September, 1819. 


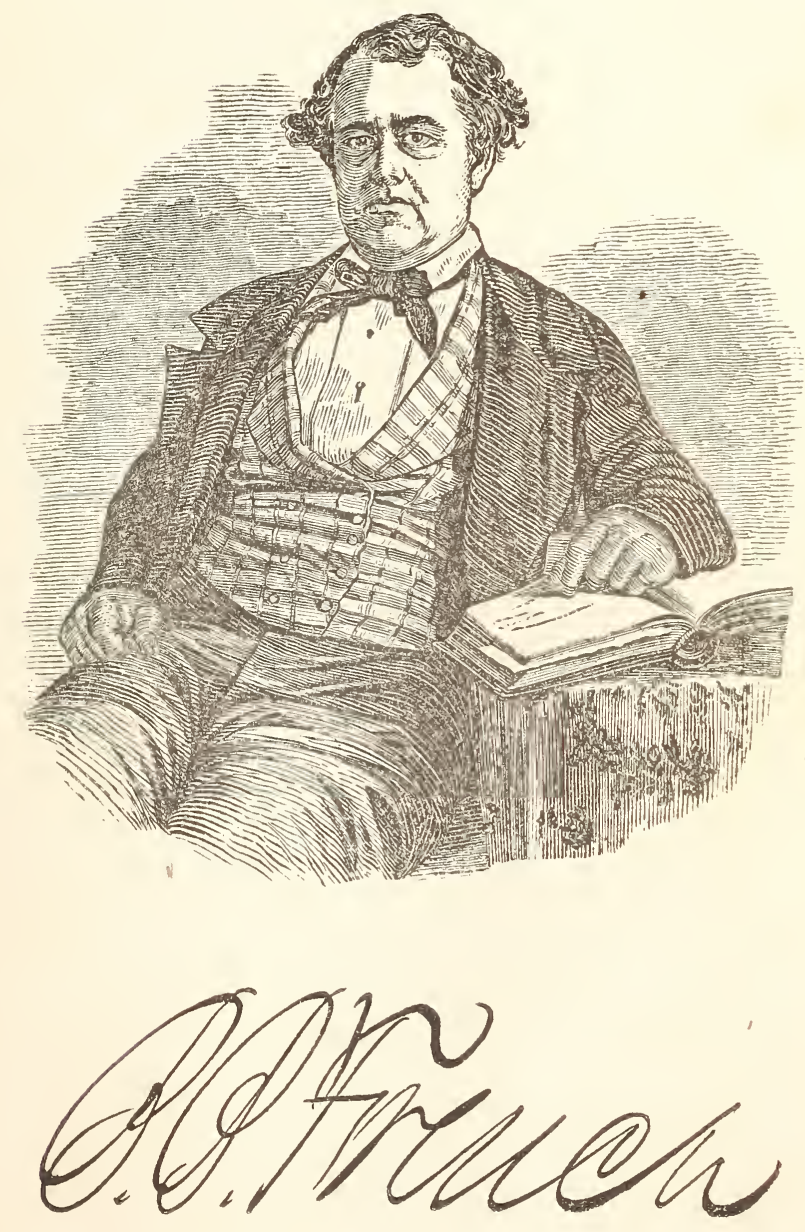



He then returned to his father's, and, although contrary to his own inclination, commenced the study of the law, which he pursued with diligence, - for five years, that being the time fixed by the bar rules of New Hampshire.

At the February term of the court of common pleas, for the county of Rockingham, held at Portsmouth, in 1825, Mr. French was admitted an attorney at law; and in the month of March following, commenced the practice, at Hookset, in the county of Merrimack, from whence, in September, he removed to Sutton. Having married Elizabeth S. Richardson, daughter of the Hon. William M. Richardson, chief justice of the supreme court of New Hampshire, he may be said to have commenced the business portion of his life upon his own responsibility, in Sutton, where he fairly settled down, at law and housekeeping, in November, 1825 .

Mr. French entered immediately into full practice, and with his industry and natural business tact, would, probably, have taken a very respectable place at the bar, had he continued in his profession. He was elected assistant clerk of the senate of New Hampshire, in June, 1826, to which office he was twice reëlected.

In September, 1827, he removed to Newport, in the county of Sullivan, and was immediately appointed clerk of the superior court and court of common pleas of that county, the duties of which offices he discharged, acceptably to every one, until the winter of 1833-4.

In $1831, \mathrm{Mr}$. French was elected a representative from the town of Newport, in his native state, and was reëlected for the two succeeding years. In the legislature, he took a high stand, not only as a party leader, but as a legislator. He was placed upon important committees, as their chairman, and was, in 1833, a member of the joint committee of 41 
the legislature, appointed to repair to Boston, and invite Gen. Jackson, then on his presidential tour, to visit the New Hampshire legislature. For three years of the time Mr. French resided at Newport, he was the editor of the New Hampshire Spectator, a popular democratic paper; and we have only to say, as evidence of the manner in which he conducted it, that its subscription list more than doubled while it was under his control. It was afterwards united with the New Hampshire Argus, and edited by Hon. Edmund Burke, and is still published at Newport.

In December, 1833, Walter S. Franklin, clerk of the house of representatives of the United States, appointed Major French* an assistant clerk in his office; upon being notified of which, he repaired to Washington, and, on the 28th day of December, 1833 , entered upon its duties. He soon after resigned his clerkships in New Hampshire, and removing his family to Washington, became a permanent resident of that city.

As an assistant clerk, he soon became popular with the house, and useful as an officer. He held the situation of chief clerk of the office under Mr. Garland, and Col. McNulty, and when the latter left the office of clerk of the house, on the 18th of January, 1845, Major French was unanimously elected to that high and responsible office. He performed the duties of the office so entirely to the satisfaction of the house, that at the opening of the 29th congress he was unanimously reëlected. Since that time he has continued to discharge the laborious duties of the clerkship of the house of representatives in a manner that has won for him the reputation of being one of the best, if not the best clerk the house ever had. He has qualifications

* Mr. French held a major's commission in the New Hampshire $\mathrm{m}$ itia, and he is so generally addressed by that title, that we assume it. 
which fit him peculiarly and eminently for the stacion.

It is known that the construction of the hall of the house renders it excecdingly difficult for most men to be heard, in reading or speaking in it, except by those in their immediate neighborhood. Mr. French's voice, though not strong, is clear, penetrating and firm; and when reading at the clerk's desk, every word he utters is conveyed distinctly to all parts of the hall. He has an acquaintance with the rules of the house, and with parliarnentary law generally, probably unequalled by any other person in the country-and a memory so retentive that he can refer to decisions and precedents, bearing upon every case that árises, with a promptness and accuracy perfectly astonishing. The writer of this has frequently, as a matter of curiosity, taken up points of difficulty in the construction of rules, and thrown them before Maj. French, in the midst of duties at the desk requiring his attention, and has never found him at fault-he being always ready to say when, by whom, and how the point had been decided. In addition to his superior fitness for the office, Mr. French's equable temper and obliging disposition have made him quite a favorite with each successive house with which he has been connected, and he accordingly possesses a high degree of personal popularity. He is a decided democrat in his political principles; but the strict integrity and impartiality of his official conduct has won for him the respect, esteem, and entire confidence of all. parties in the house.

As an indication of his indefatigable industry, as well as the extent to which his business talent is appreciated, it may be mentioned here, that he is, at this time, clerk of the house of representatives of the United States-an alderman of the city of Washington-grand master of the Masons of the District of Columbia--and president of the Wash- 
ington and New York Magnetic Telegraph company. Yet such is the extraordinary energy and capability of the man, that he discharges the multifarious duties of all these offices as fully and as faithfully as though he devoted his whole time and attention to each. Amid all his business engagements, in the fulfilment of which no man is more prompt or scrupulous, he found abundant leisure to deliver scientific lectures-to write highly finished articles for the best magazines, and other literary, political, and scientific periodicals-to indulge his fancy for field sports-to conduct, with great regularity, a very extensive correspondence-and to "cultivate the muses," of which "gentle companie of mine" we think he is no ordinary favorite.

Although he has been, for some years, a resident of Washington, he retains a deep and ardent love for New England, of which time does not seem, in any degree, to abate the fervency.

As a man, Maj. French is liberal, generous, and charitable, with a moral character above reproach. As a citizen, he is public spirited and exemplary. As a friend, warm hearted, reliable, and zealous. In all the relations of life-as a man-citizenpublic officer-he has been distinguished for the scrupulous discharge of his whole duty, and inflexible fidelity to the numerous trusts committed to his charge.

Note.-Since the above was written, the whigs now having a majority in the house, the subject of our sketch, although unanimously supported by his own and by many of the opposite party, among whom was the venerable John Quincy Adams, was not reëlected for the thirtieth congress. A better man cannot easily be found, or a more efficient officer. 


\section{EDWIN WHITE.}

This artist was born on the 21st of May, 1817, at South Hadley, Massachusetts, a village surrounded by all that is beautiful in scenery, and one of the most delightful in New England. When a boy, it always afforded him great delight to rove in the woods, to gaze upon the beauties of nature, and for hours to follow the brooks up some deep, dark ravine. At the age of seventeen, he made the acquaintance of Mr. Collins, a celebrated portrait painter, of Albany, who taught him to set the palette, which was about all. With this limited knowledge, Mr. White commenced painting on his own account, in his native village. He subsequently went to Hartford, and thence to Bridgeport, in Connecticut, where he spent some four or five years, painting portraits, when an event occurred which had, and will continue to have, an important bearing on his life. "I had," said he, in a letter to a friend, "the imprudence to get married-and that imprudence happened to be the best thing I ever did in my life."

In 1840, Mr. White removed to New York city, with the determination to devote himself to the study of painting according to the principles of the art; he having previously been governed entirely by feeling. With this view he placed himself under the instruction of a very able teacher, and the admirable pictures from time to time exhibited in New York, afford proof of his success. He is modest as he is meritorious, and must, in a few years, hold no inferior place among the artists of our country. 


\section{MRS. HAMILTON.}

Age silvers o'er the hair and dims the eye, And things are not as they were wont to seem; But, unforgotten one! hough years pass by, The memory of the heart, it still is green.

What a world of thoughts and feelings arise in perusing old letters! "What lessons do we read in the silliest of them; and in others what beauty, what charm, what magical illusion wraps the senses in brief enchantment! But it is brief, indeed. Absence, estrangement, death, the three great enemies of mortal ties, start up to break the spell. The letters of those who are dead, how wonderful. We seem to live and breathe in their society. The writers once, perhaps, lived with us in the communion of friendship, in the flames of passion, in the whirl of pleasure; in the same career, in short, of earthly joys, earthly follies, and earthly infirmities. We seem again to retrace these paths together; but are suddenly arrested by the knowledge, that there lies a vast gulf between us and them. The hands which traced those characters are mouldering in the tomb, eaten by worms, or already turned to dust.

Letters from those we once loved, who perhaps are still living, but no longer living for us. It may be they grew tired of us; it may be we grew tired of them; or the separation may have arisen from mutual imperfections in character. Still the letters recall times and seasons when it was otherwise, and we look upon ourselves out of ourselves, as it were with much melancholy interest. That identity of the person, and that estrangement of the spirit, who can paint it?

There is still a third class of old letters on which 


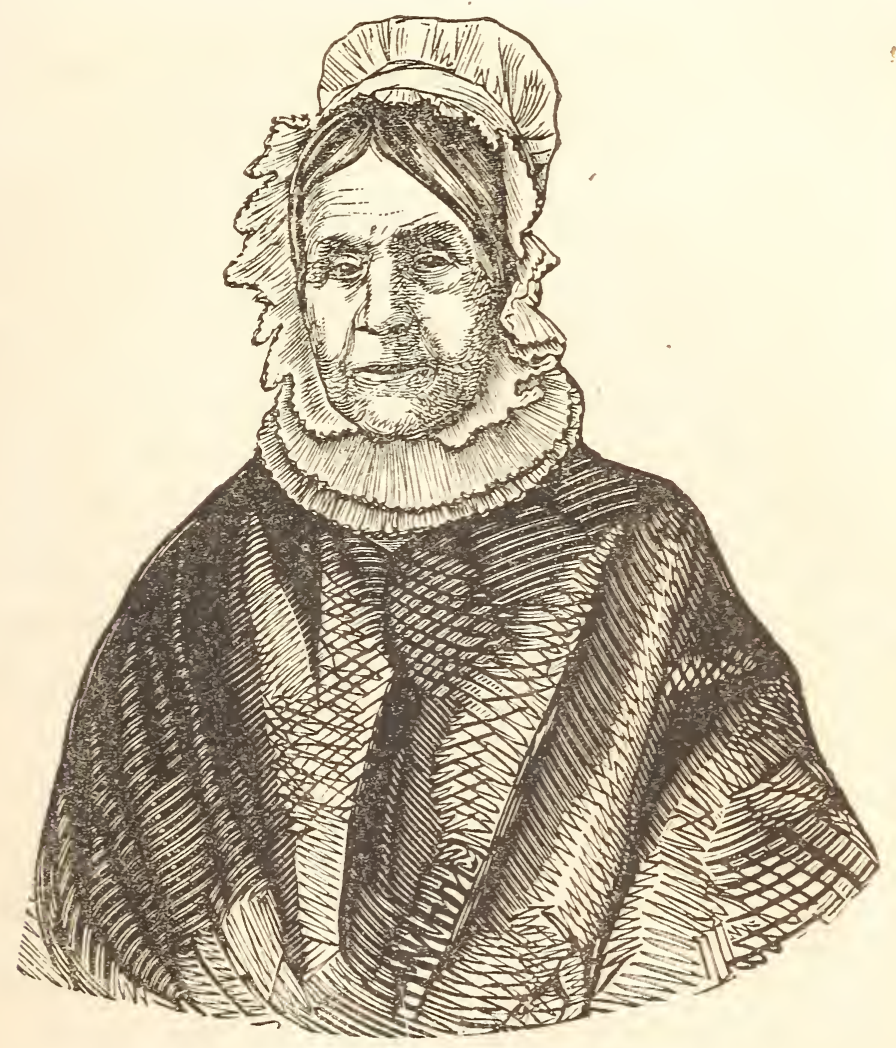

MRS. H A IL T ON 。 

the heart delights to expatiate; those of the still living, but the absent. Oh! what do they not afford of delight? They have the whole witchery of beauty, love, and truth in them, without one speck or flaw to lower the tone of that enchantment they contain."

The above remarks were suggested by the perusal of a letter written by the venerable relict of General Alexander Hamilton, nearly fifty years ago. Those fingers are now tremulous with age, and that eye which might have maddened an anchorite, is now dim. In a few years at most, will her earthly career be ended, but her memory will dwell long in the grateful hearts of those, who have been the recipients of her bounty. Venerable lady, piercing was thy shriek of agony, when the news of thy husband's murder was brought thee as thou wast worshipping in the house of God. But "sweet are the uses of adversity." In the darkest thunder cloud sleeps the brightest lightning, and though on earth there may be many sorrows, yet there is a better land

"Where every heart rejoins its kindred heart, Where, in a long embrace that none may part, Fulfilment meets desire; and that fair shore Beholds its dwellers happy evermore."

Mrs. Hamilton must be nearly eighty years of age. She is head directress of the New York Orphan Asylum at Bloomingdale, of which excellent institution, she and Mrs. Bethune, the second directress, were the founders. Previous to the establishment of this benevolent institution, there was no public receptacle for the numerous unfortunate infants, which are so frequently left by their depraved parents, to perish in the streets of the great metropolis. 


\section{JACOB KNAPP.}

The following sketch of this celebrated baptist minister, whose preaching has, under the blessing of God, produced such abundant fruit, in many portions of the Union, cannot but be read with deep interest. It was at Washington city, on a glorious spring afternoon, that the attention of the writer was first called to Mr. Knapp, as in the clear waters of the Potomac, whose shores were lined with thousands of spectators, this modern apostle was baptizing numbers upon a profession of their faith. A magnificent spectacle was that! and tears, which had seldom flowed before, were seen in many an eye. So affected was one notorious profligate, on seeing his wife baptized, that he threw off his coat, and marched into the water, begging to be baptized with her!

The Rev.'Jacob Knapp, Jun., was born December 7th, 1799, in the town of Otego, Otsego county, New York. His father's name was Jacob, the son of Luke Knapp. His mother's name was Lucinda Mayhew. His father, though a shoemaker by trade, spent the most of his days in agricultural pursuits; and, though poor in this world's goods, was industrious and virtuous. Being a member of the episcopal church, until after his son Jacob had entered the ministry, he brought up his children to abstain from all bad habits, and to attend to the forms of religion.

From six years of age to eighteen, the subject of this narrative dwelt with his parents in Masonville, Delaware county, New York, and was brought up to apply himself indefatigably to all kinds of hard labor, seldom being allowed a holiday, winter or summer. This excessive industry arose in part 
from principle, and in part from necessity; his mother leaving twelve children, at her decease, and his father having eight more by his second wife, all of whom had to be supported by the industry of the family. In the seventeenth year of his age, he was called, in the providence of God, to follow his mother to her grave. The serious impressions produced by an early religious education, on the mind of Jacob, were deepened by this bereavernent, and continued to increase until they resulted in a hope of a glorious immortality beyond the grave. Often did he lay himself on her grave, in the cool pale rays of the moon, bathed in tears, in prayer to God for the salvation of his soul.

In the winter of 1819, he professed his faith in Christ by being baptized into the fellowship of the baptist church of Masonville, Delaware county, New York. Immediately after this, he began to be impressed with a sense of his duty to preach the gospel; but, conscious of his weakness, unworthiness, and want of education, he could not think of entering upon a work so responsible, without devoting some years to the cultivation of his mind; to this he felt himself as really called of God, as to the work of the ministry. From his nineteenth to his twentieth year, the last year of his stay with his father (for his father gave his sons the last year of their minority), his nind was constantly occupied with the duties, qualifications and work of the ministry. The world had no charms - he sighed and prayed for the opening of some way by which his mind might be cultivated, and he thereby qualified for usefulness. At this time he was living with his father, on the head waters of the Allegany. Being young, and unacquainted with the world, and having no knowledge of any institution or society, by which indigent young men, who were candidates for the ministry, could be aided, he was at a loss to know which way to turn. On the second day of 
December, 1818, he shouldered his pack, and "went out, not knowing whither he went." His footsteps were first directed to Delaware county, where an opportunity presented itself for him to work for his board and attend school. When he started upon his journey of two hundred and ten miles, he had but five dollars, and wishing to make the most of them, to further the great end in view, he performed this journey without expending more than fifty cents, and yet he was as independent as the king in his chariot, for he paid for all he had, (his lodging), and ate his meals from his pack, drinking the pure water from the mountain's base, under the blue arch of heaven. After struggling on for some months, overcoming obstacle after obstacle, chopping cord wood by moonlight, to meet the necessities of nature, he accepted the invitation of an uncle in Spencertown, eighteen miles east of Hudson, to board with him and attend school.

After the winter had rolled off, and the spring of 1821 was approaching, he found his scanty stock of clothes exhausted, his cash reduced to twenty-five cents, the great end for which he had sacrificed all things, as far ahead as ever, and there was no friend to whom he could look for aid. Beg he could not, but to dig he was not ashamed. He finally resolved to return to Delaware county, and let himself for a time at rafting and running lumber, as he could command good wages in that service. He then took his pack, containing what few articles of clothing he had, and provisions for a journey of one hundred and twenty miles, with but twenty-five cents in his pocket, and started off. A severe storm of snow and rain commenced the day he set out on his journey, which continued for three days. When he arrived at the North river, he found the expense of crossing to be twenty-five cents; but, upon telling the ferryman that he had but twenty-five cents in the world, and a hundred miles 
yet to travel, a discount of one-half was readily made, leaving him now one York shilling for one hundred miles travel. After beating on through rain and snow until towards evening, a gentleman gave him an invitation to ride, and while calling to feed the team and warm himself, his pack, containing his all, was left in the sleigh. On returning, they found that either a dog, or some inhuman being, worse than a dog, had taken the pack with its contents. It was now that the school of affliction was accomplishing no inconsiderable part of Mr. $K$ 's education. He found himself among stranger's, far from friends or acquaintances, homeless, friendless, and pennyless. He thought of his father, but he was three hundred miles off-of his mother, but she was in her grave. That night he traveled until a late hour, put up at a tavern, without a dry thread in his garments, hungry, fatigued, "cast down, but not destroyed." The next morning he put on his wet garments, paid half his York shilling for his lodging, and traveled on. He called at different places, inquired for work, and told his circumstances, but no one wanted laborers, and no one invited him to eat a mouthful of food, until about noon, when a kind hearted lady gave him a dinner, which was very thankfully received. Strengthened by this, and encouraged by the promises of God, he completed his journey. Here, on the head waters of the Delaware, he labored a few weeks. Having supplied himself with summer clothing, and money enough to pay his tuition for one quarter, he started for the academy in the town of Butternuts, under the instruction of the Rev. Mr. Collins. Here he made an effort to procure his board for labor, in which he was unsuccessful. Mr. Collins having learned the circumstances of Mr. Knapp, invited him to board with him, promising him what work he had, agreeing to wait for the remainder until it could be paid, by teaching or otherwise. 
Here he found himself behind the most of the school, and his being unaccustomed to study, combined with sedentary habits, his health was taxed, his patience tried, and his ambition chastened. At the close of the term, however, the principal of the academy awarded him the premium for excellence in performing his part at the putlic exhibition; this premium, however, had nothing to do with general scholarship. Harvest time coming on, he was compelled to leave his studies for a time, to enter the harvest-field, to replenish his scanty stock of means for prosecuting his studies, during which season he procured enough to defray the expenses of a second quarter. Through all these efforts to prosecute his studies he subjected himself to great self-denial, wearing cotton pants, and going in his shirt sleeves in summer, to keep his coat for winter. Towards the close of the quarter, thinking himself not sufficiently qualified to teach in that section, yet being compelled to engage in some business to further his object, he thought of going west to engage a school for a season. But in the mean time, a powerful revival broke out, and his whole soul was enlisted in it. A general anxiety pervaded the entire community, to have him remain. The ladies, without his knowledge, prepared him a suit of clothes, and invited him to board among them the next quarter, free of expense. This act of kindness, so unexpected, and so much needed, almost broke his heart, and produced gratitude inexpressible, accompanied with an effusion of tears. In 1821, he taught a school in New Lisbon, Otsego county, and paid off all his former bills.

In the spring of 1821 , he was licensed to preach, by the church in Masonville, with which he first united, and was commended by that church to the literary and theological institution in Hamilton, which was then in its infancy. The course of study at that time was three years, which he com- 
pleted, and received his diploma, in June, 1824. He then received and accepted a call from the baptist church in Springfielả, Otsego county, New York.

In September following he was ordained to the gospel ministry, and in the same month was married to Miss Electa Paine. After serving this people with some success, for five years, he resigned, and accepted a call from the infant church in $\mathrm{Wa}$ tertown, Jefferson county, New York. During his labors with them, for three years, he baptized about three hundred persons. He then, under the reviving influences of God's spirit, (poured out upon the churches, the ministry, and the impenitent,) received great light, and experienced a great change, both in his views and feelings, as well as in his character and sense of action. From a clear conviction of duty, he resigned his charge as pastor, and devoted himself to the work of an evangelist. This step was taken in 1832. At this time he had a wife and four children, for whom to provide, their expenses yearly-and as there were no benevolent societies to aid evangelists, and the churches in that section could hardly support their pastors, he could see no way by which the expenses of his family could be met. But, being clear in his convictions of duty, he resolved to go as far as what means he had could carry him, and trust to God for the future.

The various steps which the providence of God have marked out for him, from that time to the present, a period of fifteen years, the scenes through which he has passed, and the success with which his labors have been crowned, cannot be particularized in this brief sketch. Suffice it to say, that during a period of twenty-three years, he has preached eight thousand five hundred sermons, and baptized, as nearly as can be ascertained, upwards of four thousand persons. Some thirty thousand persons have made a profession of religion, in con 
nection with his labors; more or less of whom have a standing in all the evangelical denominations of this country. Between thirty and forty of those converted under his labors, have entered the gospel ministry.

It is well known in Baltimore, and its vicinity, that the great Washingtonian reformation can be traced to a sermon which Mr. Knapp preached to the Young Men's Temperance society in that city.

The peculiar style of $\mathrm{Mr}$. Knapp, it would be difficult to describe. It is that, however, which brings the intellect down through the heart, and melts its precious metals in that hot furnace. There is an edge in all he says. "Playful, but not light; imaginative, but not dramatic; using common words, with uncommon power; speaking to you, as if he expected to convince you; decided, and full of earnestness;" he is cheerful, without levity, and grave without gloom; mighty in the pulpit, but no less mighty out of it; he is an evangelist that need not to be ashamed.

We cannot close this memoir without giving a single illustration of his original and pointed style. Preaching, very recently, from the text, "Lord, save me or I perish," Mr. Knapp observed, that had the exordium to Peter's prayer been one-fourth as long as that of many modern preachers, the sinking disciple must have been at least seventy feet below the surface, before his petition could have been uttered! 



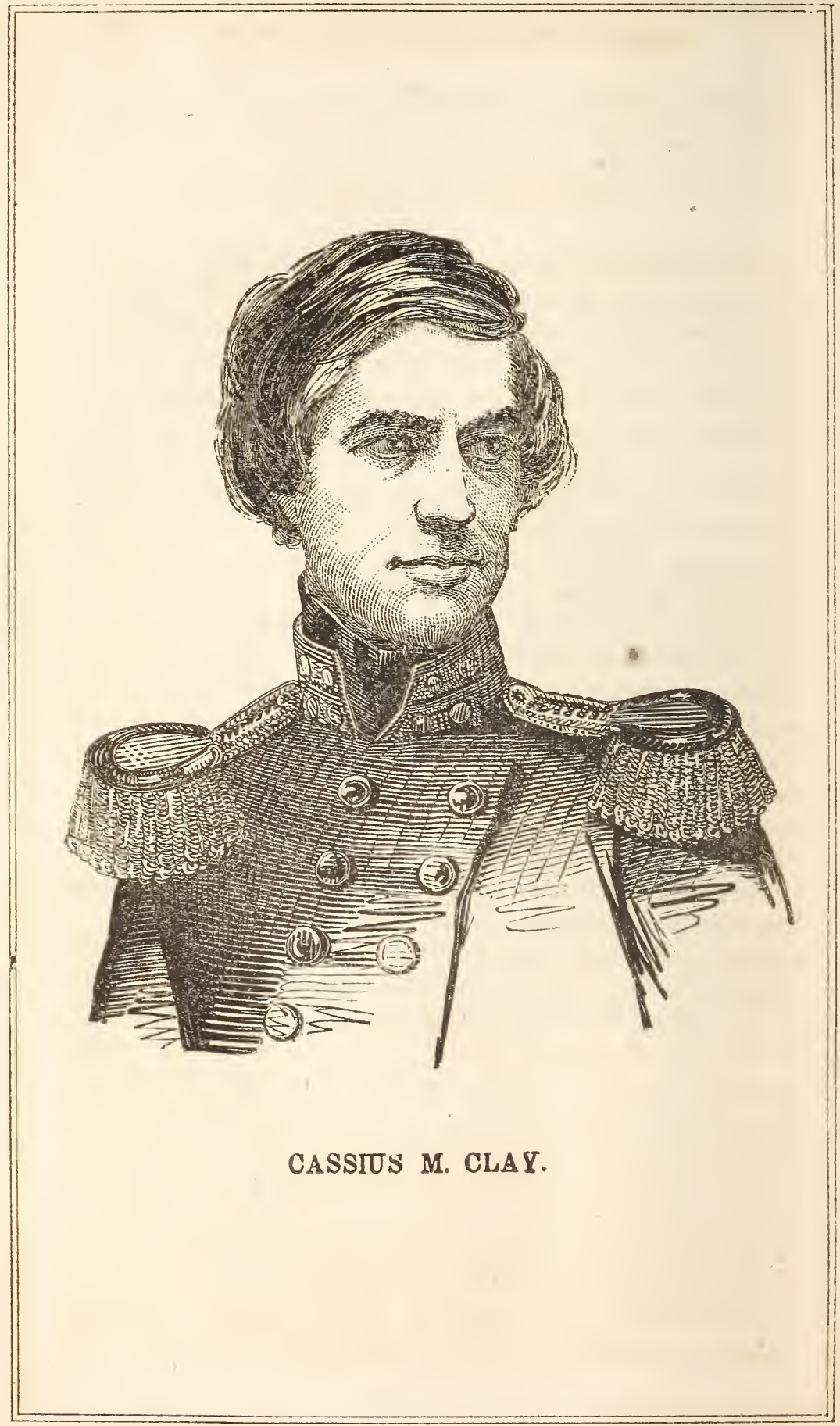




\section{CASSIUS M. CLAY.}

In presenting the portrait of Capt. Clay, it is not our intention to dwell upon the moral courage he displayed by the establishment of an abolition paper at Louisville, in the midst of a slave holding state; nor upon the exciting scenes which attended the removal of his press to Cincinnati. We notice him only in his military capacity. At an early stage of the Mexican war, he with many of his brave companions in arms having been captured, upon their liberation, a card was published by his men, dated Lexington, Kentucky, Oct. 20, 1847. The following is an extract:

"When Captain Henry made his escape, and the Mexican commander, excited by the event, gave orders for the massacre of the Americans, Captain Clay exclaimed, 'Kill the officers-spare the soldiers!' A Mexican major ran to him, presenting a cocked pistol to his breast. He still exclaimed: 'Kill me-kill the officers-but spare the menthey are innocent!' Who but C. M. Clay, with a loaded pistol at his head, and in the hand of an enraged enemy, would have shown such magnanimous self devotion? If any man ever was entitled to be called 'the soldier's friend,' he is. He was ever watchful and kind towards us, allowing every privilege that would be granted by our enemiesturned all orders and commands into advice and consolation; and upon our march to the city, would take turn by turn, allowing us to ride his mule, that we might stand the march of forty miles a daydivided the last cent of money he had with us, and resorted to every sacrifice to make us happy and comfortable. He disposed of his'mule, when he found it necessary - the only animal he had; his 
buffalo rug, his watch, and all his clothes but one suit, and supplied our wants. He not only acted in this manner towards those under his immediate command, but to all; and expressed his regret that he was unable to do more.

"We make no comments upon the character and conduct of Captain Clay. We state facts-we feel, but have no language to express our feelings."

\section{JOHN L. PERRY.}

Perhaps few professional men have experienced greater difficulties than Doctor Perry. Previous to commencing his studies, he was a journeyman printer. While thus employed, he won the regard of a benevolent physician of Albany, who aided him in the study of medicine. He was afterwards assisted by another medical friend, and eventually took his degree of M. D. He then, we believe, commenced on his own account at Saratoga; but having no funds, and being sadly discouraged by the lack of patronage, he having the misfortune to look young, he returned to the printing office, where he remained until his marriage with a very amiable lady. Matters then began to take a new turn. He resumed the practice of his profession at Saratoga, with increasing success, until he now enjoys an enviable reputation.

How truly has it been observed that love is inspiration. It encourages to great deeds, and developes the noblest faculties of our nature. Few men have flourished, who, were they to be candid, would not acknowledge the vast advantage they have experienced in the earlier years of their career, from the spirit and sympathy of woman. 


\section{JOSEPH GALES.}

Thousands who have for years, been daily readers of the Washington city "National Intelligencer," have perhaps, never formed a correct idea of the man from whose pen flow the statesman-like articles which fill the columns of that paper. From a political warfare of so many years, contending against powerful partizan opponents, it may reasonably be imagined, that Mr. Gales has been concentrated into a mere mass of political gunpowder, and that all the kindly sympathies of our nature have long been evaporated. Never was there a greater mistake. Instead of the sour-looking, razor-edge physiognomy of too many of those who are doomed to "nuake bread from brain," our subject is the very personification of good nature. He is just such a man as a wounded deer would run to for succor, or a stranger, robbed of his pocket book, would ask for a temporary loan. Short in stature, corpulent, and with hair whitened by the snows of time, he is the centre of a circle of grateful hearts who have never appealed to his purse in vain.

Mr. Gales, as has been set forth in italics, and large and small capitals hundreds of times, by the opposition presses, is an Englishman. His father, now deceased, once conducted a highly respectable paper in North Carolina. His son Joseph was a journeyman printer, and previous to coming to Washington, it is said he worked a week in Philadelphia. On looking over his work, there were so many errors, that he made a present of the composition to a fellow workman, on the condition that the latter would correct it. He then, with others, established the respectable paper which he still conducts. Of the character of the Intelligencer it 
is unnecessary to speak. Its immense circulation among men of both parties, is sufficient evidence of its standing.

Generous to a fault, the munificence of $\mathrm{Mr}$. Gales has frequently involved him in temporary pecuniary difficulties. But even at such times, his benevolent feelings would still predominate. We have heard that many years ago, the holder of an unpaid promissory note, unacquainted with the man, placed it in the hands of the sheriff, who served a writ upon Mr. Gales. The latter, accompanied by the officer, went to a friend across the street, and borrowed the money. But the next moment, one of his old workmen, in great distress, accosting him, Mr. Gales immediately handed him half the money he had just borrowed, and told the sheriff to take the remainder and "call again tomorrow."

It is said that many of his superannuated workmen have for a long period been supplied by him with a weekly allowance. He has a fine country residence in the vicinity of Washington. $\mathrm{He}$ is married, but has, we believe, no children. His partner, W. W. Seaton, Esq., has for many years, been mayor of the city of Washington, and is one of the regents of the Smithsonian institute.

Verging upon three score, it cannot be long before Mr. Gales will pay the debt of nature; but when that event shall occur, the flowers upon his grave will be watered with many tears. 


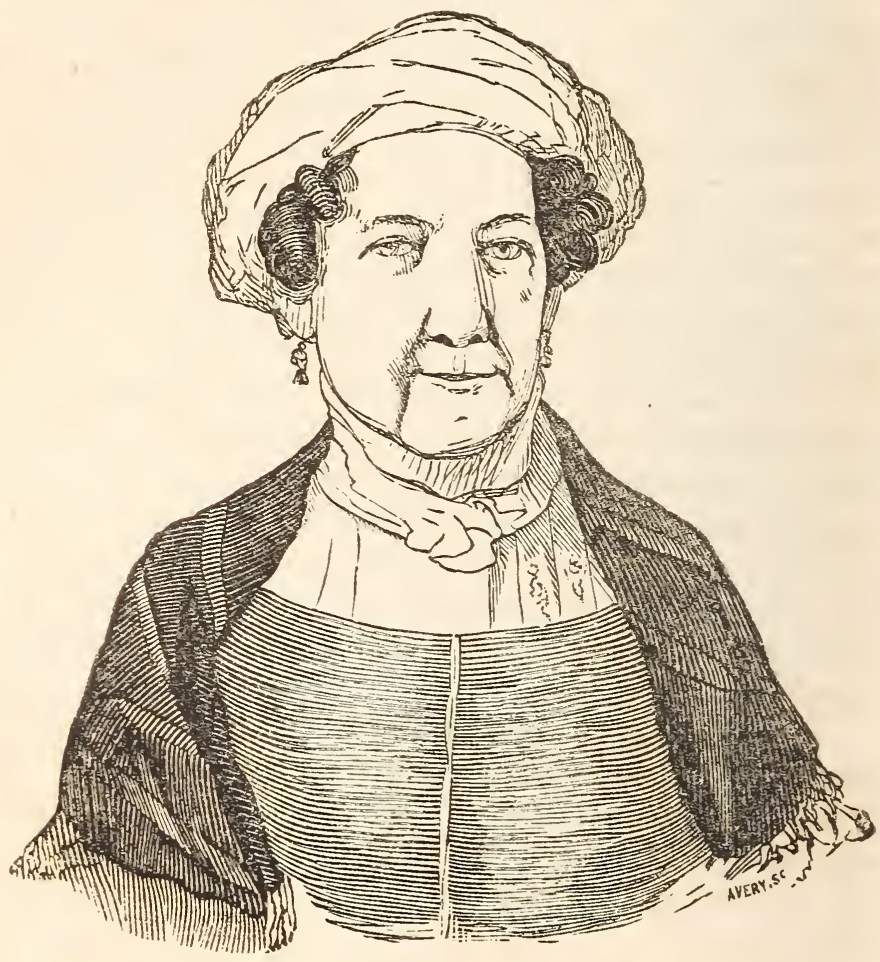

MRS. MADISON. 


\section{MRS. MADISON.}

This venerable and dignified lady, a "rose blooming in Alpine snows," now nearly eighty years of age, still resides at her hospitable mansion, in Washington city, where "lang syne" she was one of the most polished, elegant, brilliant and beautiful ladies that ever graced the social circle. Her manners have all the stateliness of "olden times," when she stood, the personification of grace, in the reception room of the presidential mansion-yet they sweetly harmonize with the changes of the present day. She has a full face, bright blue eyes, beaming with benevolence, and a somewhat florid complexion. Her house, says a gentleman who recently visited it, is a miniature museum. The greater part of her collection is still at her former residence, in Montpelier, Va.; but what has been removed here, well repays the visiter, aside from the gratification of seeing their renerable possessor.

It is well knowit that in addition to that of the president, the mansions of Mrs. Madison and ExPresident Adams, are thrown open for the reception of visiters, on New Year's day. Two winters ago, on one of these occasions, it is said that the venerable ex-president, on the expiration of the usual visiting hours, walked to the residence of Mrs. Madison, when he, there and then, in the good old republican style of other days, not only wished her a "happy New Year," but proved his sincerity by imprinting a kiss upon her matronly lips.

It was a beautiful incident, these two relics of an age gone by, thus meeting each other in the twilight of existence. 


\section{JAMES KENT.}

It has been truly said, that with energy, perseverance, and a well balanced mind, man may accomplish almost every thing attainable by human effort. What is it but well directed energy, that lifts man above man, and sets in motion the mighty and varied powers that heaven has granted himthat sets him beyond the reach of competition, even upon the topmost pinnacle of fame-a bright star whose name is spelt in diamonds, never to be dimmed, and never to be forgotten?

An illustrious exemplification of the truth of this remark is furnished by the life of the late Chancellor Kent, who, on Sunday evening, December 13, 1847 , at his residence in New York city, left a world which he has benefitted and adorned, for that blessed immortality which is the Christian's hope while on earth, and his reward through eternity.

James Kent, says the New York Tribune, was born on the 31st of July, 1763, in Fredericksburg, then part of Dutchess, but now of Putnarn county, New York, and was the eldest son of Moss Kent, a graduate of Yale college, Connecticut, who was admitted to the bar of Dutchess county in 1756 . His grandfather, Rev. Elisha Kent, a native of Suffield, Connecticut, was for thirty-six years minister of the Presbyterian congregation of Kent's parish in Dutchess county, and his brother, Moss, sat in the senate of this state, and in congress, and was for some time register of the court of chancery.

Mr. Kent was sent to school at Norwalk, when but five years old, and was placed under various instructors until he entered Yale college in September, 1777, more than seventy years since. From the precepts, and yet more the example, of those 
pious puritans, among whom his early years were passed, he acquired that simplicity of character and purity of morals which he preserved through life.

In July, 1779, New Haven was invaded by the British forces, the college broken up, and the students dispersed. In his exile, young Kent met with Blackstone's Commentaries, read, admired, and, at sixteen, determined to be a lawyer. He finally left college with high reputation; studied law with Egbert Benson, attorney-general of New York; was studious, temperate, and a water-drinker, indulging in none of the fashionable pleasures or dissipation of the times. An enthusiastic admirer of Nature's charms, the love of reading was his ruling passion. He was cheerful, lively, and communicativeyoung, ardent, active, and persevering-his mind was early stored with useful knowledge, and the morning of his life gave promise of the noonday brilliancy of his remarkable career.

In April, 1787, he was admitted, at Albany, a counsellor of the supreme court-in 1790, and again in 1792, elected to the legislature by the people of his native county. From the purest motives, and believing its policy the best for his country, he joined the federal party, became the steadfast friend of Jay, Hamilton, and others of its leaders, to whose political principles and usages he steadily adhered, until, in 1819, it ceased to exist.

After failing to be elected to congress by a few votes, he removed, in 1793, from Poughkeepsie to New York, was appointed professor of law in Columbia college, and delivered a course of lectures the year following. In 1796, he was appointed a master in chancery--there were then but two of them, and next year called to fill the office of recorder of New York. In 1798, he ascended the supreme court bench as one of the judges, and removed his residence to Albany, where he commenced the practice of delivering a written, argumentative opinion, 
supported by legal authorities, in every case of sufficient importance to become a precedent for the future. Thus commenced that series of recorded judicial decisions which have enriched the jurisprudence of New York, and proved alike useful to the legislator, the judge, and the codifier.

Judges Kent and Radcliffe revised the statutes of our state in 1800. In July, 1804, the former was appointed chief justice of the state, and continued to preside in the supreme court until his appointment as chancellor, in February, 1814. His legal opinions, delivered while in the supreme court, are contained in sixteen volumes of well known and highly appreciated reports.

As chancellor, which high office he filled till 1823, he is understood to have displayed to great advantage these excellent business habits, and that promptitude which marked his career through a long and invaluable life. A few favored lawyers had, before his time, monopolized chancery business-he threw its doors wide open to the profession-and was unwearied in his efforts to despatch the causes brought under his cognizance.

By the constitution of 1821 , the judges were removable from office at sixty years of age; and, on July 31, 1823, he, having reached that period, retired, after hearing and carefully deciding every case that had been brought before him. The mernbers of the bar in New York and Albany took that occasion to bear ample testimony to his worth and usefulness, and to acknowledge the benefits which society had derived from his learning, wisdom and assiduity. In 1824, he became a second time law professor in Columbia college, and in 1826 appeared the first volume of his inestimable Commentaries on American Law, which were concluded in four volumes in 1830, and have been extended and improved by him, with great care, from that period to this. 
He was elected president of the New York Historical society in 1828, and was an original member of the Literary association of Yale college, formed in 1780, under the name of the Phi Beta Kappa society. In 1821, he represented Albany county in the state constitutional convention. He was a distinguished ornament of that learned and patriotic body, and steadily adhered to the opinion that with a constituency of freeholders, owners and cultivators of the soil, the unincumbered possessors of happy homesteads, the liberties of the country would be safest. In 1785, he married a sister of Gen. Theodorus Bailey, a lady now nearly eighty years old, and who survives him, after enjoying over three score years of uninterrupted domestic felicity. His farnily consisted of two daughters and one son, the learned and well known Judge Kent, who resigned the office of circuit judge here some years since, and more recently gave up his professorship at. Cambridge, that he might cheer the latter days of his venerated and excellent father by his company and personal attentions.

He was an exemplary Christian, a steadfast and affectionate father, a tender husband, an ardent patriot, and a true lover and defender of his country's rights. So highly are his works esteemed abroad that the lord chief justice of England, Baron Denman, wrote to Judge Kent, some years since, to acknowledge the indebtedness of the legal profession throughout the world to him for his able commentaries. 


\section{OTIS ALLEN BULLARD,}

Was born at Howard, Steuben county, New York, on the 25th of February, 1816. His parents came from Massachusetts, and were among the earliest settlers of Steuben county. His father was a farmer of good repute. When the latter died, Otis was but fourteen years of age, and was apprenticed to the business of wagon making and sign painting, those branches being frequently united, in many of our villages. His love of the fine arts was first awakened, by the arrival of a portrait painter in that place. Eager to obtain some knowledge of the art, Otis exerted himself to the utmost to raise the ways and means, and applied for instruction; but the artist refused to disclose any of his professional secrets. At that period Otis was eighteen years of age, and the productions of this painter were the first oil paintings he had ever seen. Ever afterwards, his mind was fixed upon painting, and although the way did not then appear, an artist he was determined to become. With this view he desired to leave his trade, for the purpose of obtaining instruction in some of the distant cities; but, at the earnest entreaty of his mother, who could not bear the idea of parting with him, he consented to remain. All his spending money was laid out in books, but he searched in vain for any which gave information on painting.

At this juncture, a friend of his, a young physician, patiently waiting, like many others, for gray hairs, to entitle him to confidence, agreed "to sit for his likeness." Otis was in his glory, as, with a painter's pencil, odds and ends of brushes, and the premises all to himself and his "subject," he com. menced his first portrait. It was, we presume, with 
some such feeling as that of an orator, making his debut, ; or of a general, about to fight his first battle. The portrait was declared to be excellent, and to his gratification it was pronounced greatly superior to those painted by the professional artist. All the people in the village declared it was like life itself; and in truth there was no fear of his falling into the difficulty of a certain artist, who, having painted a horse, thought it necessary, for the information of people not judges of the fine arts, to inscribe underneath the animal, "This is a Horse."

When of age, Mr. Bullard visited Massachusetts and Connecticut, where he found friends who gave him the requisite instruction. He then commenced business, as a portrait painter, at Hartford, where he met with good success. During several subsequent years, he painted portraits in Massachusetts, and in the western part of the state of New York.

In 1841, he married the eldest daughter of A. A. Olmstead, Esq., and, since the winter of 1843, he has made New York city his permanent place of residence.

Recently, his attention has been principally directed to illustrations of the manners and customs of American life, and to historical compositions. Among his latest productions are, "Judith in the tent of Holofernes," "Horse Trade," "Sam Slick," and the "Last Blanket."

He is at present engaged upon several pieces of stirring incident in our own revolutionary history.

In conclusion, we may safely say, that if he con. tinue his hard study and close application, there is no danger that the American school of painting will lose aught at his hands. 


\section{THOMAS RITCHIE.}

"A fine Virginia gentleman, All of the olden time."

The annexed outline sketch of Mr. Ritchie, although copied from a portrait taken when he was a younger man, will yet be recognized as a faithful delineation of his amiable physiognomy.

It is scarcely necessary to refer to the past history of this veteran editor, who, for so long a period, so ably conducted the Enquirer, at Richmond, Virginia, where, surrounded by his family, perhaps no man was ever more beloved and respected.

Upon the retirement of Messrs. Blair \& Rives, from the Globe, at Washington, Mr. Ritchie, with his business partner, Major Heiss, purchased the establishment, and continued the paper, under the name of the Union.

As generalissimo of the democratic party, Mr. Ritchie has had full employment for his energies, not only in looking after the enemy, but in reconciling sectional difficulties among his own forces. We will venture to say, that could he have formed but a faint idea of the boisterous nature of the elements over which he was called to preside, he would have pondered long before leaving his former post. "Peace! it is peace that the pure heart ever longs for; and in many spots fancy teaches us to believe it rests - the village, in its mantle of green treesthe cottage, with its humble thistle and curling smoke" - and even in the palace-but it seldom hovers over the chair of a political editor! 


\section{J. DANFORTH.}

This well known artist, is a native of Hartford, Connecticut, from whence he removed to New York city, in 1824. In 1826, with a view to his professional improvement, he went to London, where he closely pursued his studies in the various galleries and schools of art. He also visited the continent, with the same object in view, devoting a portion of his time to engraving. In addition to numerous plates of a private character, were several for the English annuals, which he executed in a style that could not be surpassed by any artist of that country. Perhaps the admiring readers little thought that the artist was an American, or they would have held up their hands in astonishment, exclaiming, "How can such things be?" One or two others, of a larger size, were commenced, but were left unfinished, with the intention of returning to England to complete them; among them was a large plate from a picture of Leslie's, in the possession of Lord Essex.

After an absence of eleven years, Mr. Danforth, with a mind laden with the treasures of rich experience, returned to the United States.

Since that time, however, owing to a profitable connection with an establishment for bank note engraving, Mr. Danforth has been unable to undertake any new work. It is understood, however, that it is his intention shortly to enter upon a more congenial employment-that of engraving a series of American subjects, from the lamented Washington Allston's pictures and outline compositions. The latter, for several years before his death, was very solicitous to procure the services of our artist, and wrote to him many times on the subject, when Mr. 
Danforth was in Europe. On his return, the request was again pressed, which resulted in an agreement to commence the work as soon as other engagements would permit. But, although every facility and encouragement was offered, by a number of Boston gentlemen, who subscribed liberally to the amount of $\$ 10,000, \mathrm{Mr}$. Danforth has hitherto been prevented from devoting his attention to it. It is to be hoped, however, that these noble productions of American genius, now appreciated in the old world, even more highly than in this country, will be clothed in an imperishatle form.

\section{THOMAS JEFFERSON.}

This illustrious man affords an additional instance of the success of well directed energy. He was born at Albemarle, Virginia, on the 2d of April, 1745. At a very early age, he was left entirely to himself, with no friend or relative to whom he could apply for advice or instruction. Notwithstanding this difficulty, by his decision and energy of character, he soon secured the esteem of a great portion of the community among whom he resided. He graduated at William and Mary's college, and then studied law. While a student, he listened to the debate on Patrick Henry's resolution against the stamp act; and the difficulties with the mother country having already begun, he was henceforth a patriot and a politician.

In 1801, having previously held high offices of trust and honor, this friendless boy was elected President of the United States. Having served two terms, he retired to private life. He died in the 84th year of his age, July 4th, 1826, just fifty years from the declaration of independence. 


\section{GEORGE D. BEERS.}

The Chinese tell of one of their countrymen who had been making strenuous efforts to acquire literary information, but who, discouraged by difficulties, at length gave up his books in despair. As he returned to manual employment, he saw a woman rubbing a crowbar on a stone. On asking her the reason, she replied that she was in want of a needle, and thought she would rub down the crowbar till she had got it small enough. The patience of the aged female induced him to make another attempt, and he succeeded in attaining the rank of one of the three first men of the empire.

Perhaps no man has exercised more patience or overcome greater difficulties in the acquisition of knowledge than the Hon. George D. Beers, a son of the Hon. Cyrus Beers, late member of congress from New York. He was born at Hobart, Delaware county, New York, in the year 1812, and shortly afterwards removed with his parents to Delhi, in the same county. Here, owing to the limited means of the family, George, at a tender age, was required to perform severe labor. When he was nine years of age, his parents removed to Walton, a distance of about eighteen miles. And although the ground was covered with snow, and the weather very severe, George had to walk the whole distance, driving a cow before him. The nearest school being at Delhi, he subsequently, for many weeks, walked that distance every Monday morning, returning on Saturday. How few youths of the present day, place a proper value upon the facilities for education.

After residing in other portions of Delaware county, Mr. Beers removed with his parents to Ithaca. 
New York. He then, amidst very great difficultics, studied law, and in his twenty-first year, after an honorable examination, he was admitted to practice in the supreme court. He now resolved to visit the far west, with the idea of "growing up" with the country, but while in Michigan, he was attacked by the cholera, and for a long time his life was despaired of. He at length, with a sad heart, and without money or friends, commenced his journey homewards. The hardships he underwent, and the sufferings he endured, can only be appreciated by those who have had the misfortune to be placed in similar circumstances. He finally, more dead than alive, arrived at Ithaca, where he slowly recovered. He then, without books or money, being at least two hundred dollars in debt, opened a law office. Circumstances more discouraging can scarcely be imagined. But his motto was "patience and perseverance," and by slow degrees he rose in the confidence of the people, many of whom were astonished at the sound legal knowledge possessed by so young a man. By close attention to business, and an unswerving integrity, the sunshine of prosperity broke out upon him, and in a few years, he had entrusted to his care, many of the most important cases ever tried in the state. From poverty, he arose to the enjoyment of wealth, which was sweetened by the reflection that it was the fruit of his own labor. When he commenced practice, one of his rules was "not to speak fast, and never to lose his temper." Would that all other professional gentlemen would follow his example.

In the course of a few years, so popular did he become in the community among whom he resided, that the man who, when a little boy, drove a cow through the snow for eighteen miles, was elected to the New York state senate. Of his course while in that body, it is unnecessary to speak. It will be sufficient to say, that he acquitted himself to the 
entire satisfaction of the respectable portion of his constituency and to the people at large. In this life, however, sunshine and shade continually alternate, and a short time ago, during his absence from home, he suddenly lost two interesting children, making the third death in his family within a very short period.

When we behold the little one suffer for a short time, and then die, the mourning heart is sometimes oppressed by the thought that springs up from within: Why is it so-why are these innocents thus brought into being to suffer awhile, and then fall to sleep in death? That such a circumstance can be reconciled with the goodness of the Creator, to us is evident-his care is over them, unseen, but near, and well he knew what hour was best to call them home. Omniscience, penetrating the dark future, could see what would be the fate of the child were it permitted to live-he could see the circumstances in which it would be placed, and his purposes did not ordain that it should perform an active part in the economy of things; he therefore sent his angels to take its little hands, and lead it to smile on death, and then enter amid the cherubic host of heaven.

The spirit flies; and lost in raptures dreaming,

Through the blue brightness of yon starry dome,

Will fancy picture holy harp strings breathing

The songs of Zion in their blessed home.

Mr. Beers has for many years been an active member of the Presbyterian church at Ithaca. 


\section{JOHN CARLIN.}

This artist, a deaf mute from his birth, was born at Philadelphia, June 15, 1813. His parents were poor, but highly respectable. His paternal grandfather, a British artillery officer, was captured at Stony Point by the chivalric Anthony Wayne. After an exchange of prisoners, being disgusted with British injustice and cruelty, Carlin came to the very reasonable conclusion, that it would be much pleasanter to be his own captain. He accordingly deserted, and concealed himself in the woods of Pennsylvania. Here, amidst the embowered shades, he fell in love with, and finally married a fair quakeress.

\section{And oft they met}

When winds sighed soft around the mountain's brow, And summer flowers with moonlight dews were wet,

To breathe in some green walk their first young vow.

In July, 1820, the subject of this sketch was admitted to the Pennsylvania institution for the deaf and dumb, where the first germs of knowledge shot forth in his darkened mind.

He has no recollection of the period when he first manifested a taste for drawing, but sometime prior to his entrance into the school, he was accustomed to trace with chalk, fantastical figures upon the floor, and which his mother would quickly deprive of their immortality by the application of the mop.

On leaving the institution in 1826, with a refined taste and an ardent love of the arts, owing to the limited means of his father, our artist, to his great sorrow, was compelled for about two years, to toil for a scanty livelihood at house and sign painting. At the age of nineteen, as a matter of pure neces- 
sity, he commenced business on his own account, at Philadelphia. He constantly, however, deroted his spare hours to the study of the principles of drawing, and in copying on canvas, prints engraved from the works of the great historical painters.

After overcoming many difficulties, Mr. Carlin saved money enough to enable him, in 1838 , to visit the old world, where he longed to drink in, at the fountain head, the wondrous beauties of the old masters. But like many of his ardent contemporaries, to his great regret, he found that his funds were not sufficiently ample to meet unexpected but indispensable expenses, in so large a field of study. After spending some time in London, he proceeded to Paris, where he studied under the celebrated Delaroche.

While in France Mr. Carlin had the good fortune to be present at the two magnificent funeral processions of the martyrs of 1830 and of Napoleon. During his sojourn too, he saw numerous instances of the difficulties under which foreign artists labor, who go to Paris without having preriously studied the French language. On one occasion, in order to serve a young fellow countryman laboring under this disadvantage, Mr. Carlin acted in the capacity of translator of written communications between him and the French professor. The class thought it remarkably singular to see a deaf mute translating for a speaking person.

A worthy friend, deeply interested in the welfare of Mr. Carlin, and knowing that pecuniary difficulties prevented his journey to Italy, introduced him to a rich Virginia gentleman. The latter expressed a desire to facilitate the accomplishment of the cherished object, and bidding our artist to be of good cheer, promised to furnish him with a thousand francs per year for three years, during the prosecution of his studies in Italy. He also requested him to get ready in a few weeks. This, thought our 
artist, was good fortune indeed, and his soul glowed with bright anticipations. He immediately commenced the study of the Italian language, and he was congratulated by his friends upon his smiling prospects. Meanwhile the Virginian had been obliged to go to England, but he had apprised $\mathrm{Mr}$. Carlin that he would shortly receive such orders from agents in Italy as would enable him to proceed to that country. Week after week, however, passed away, and no order came. Hope, with her silver tongue, said it would come the next week, the next month, but it came not, although the expectant waited with an aching heart. At length, after waiting for more than a year, his spirits sank within him, and no pen can describe his anguish of soul. In his case was a powerful exemplification of the fact, that "Hope deferred maketh the heart sick." Under these circumstances, painting became an object of aversion, and Mr. Carlin returned without ambition, to the United States. Here he resolved to abandon his profession, but ex-Governor Seward, the late Col. Stone, and other sympathizing friends dissuaded him, and urged him still to paint. At length, after experiencing a severe struggle with poverty, he came to the conclusion that he would paint miniatures only, and that for a livelihood. This he soon found much more profitable than either historical or portrait painting, and in New York city, where he is permanently settled, he is now well patronized in this humble but beautiful art.

In December, 1843, he married Miss Mary Wayland, a former pupil of the New York institution for the deaf and dumb. They are blessed with two sweet children, who, contrary to what might have been the opinion of certain thick headed philosophers, are neither deaf nor dumb.

In addition to his artistical merits, Mr. Carlin is a poet of no mean pretensions, as his numerous published pieces well prove 


\section{ARPHAXAD LOOMIS,}

Was born at Winchester, Connecticut, on the 9th of April, 1798. His father was a farmer, in very moderate circumstances. Arphaxad was the fifth son, and from the time his father removed with his family to Herkimer county, New York, until his fourteenth year, he was accustomed to steady service on the farm. He enjoyed, however, the usual opportunities afforded to boys in the country, of attending the common school, and which he improved to good advantage. When fourteen years of age, his father hired him out as the teacher of a common school, seven or eight miles from home. He was then quite small of his age. His agreement was six dollars per month, and to "board round." He subsequently, for several successive years, taught school in the winters, and during the summers he attended the academy at Fairfield, Herkimer county, paying his tuition by his winter earnings. According to the common practice of that institution, he lived in his room, at the academy, upon his own food, a week's supply of which he was accustomed to carry from his father's house, a distance of four miles, every Monday morning. He also wore the home-made garments of his father's household. It was understood, however, that he was not to be a burden to the family, even to this extent, and accordingly, his winter's earnings were, with the exception of "tuition," and "bookmoney," regularly paid over to his father, as an equivalent for his supplies. He was very desirous of going through a collegiate course, but his resources would not permit the gratification of this ambition.

In 1818 , he entered his name as a student in a 
law office at Johnstown, Montgomery county. At the end of three months, however, his funds became exhausted, and he was compelled once more to commence teaching. Although he sometimes brooded in deep despondency over his want of means to prosecute his legal studies, he was determined not to "give up." Having heard that a teacher of his acquirements might probably find good employment at Watertown, Jefferson county, he borrowed ten dollars of his father, and on the 20th of December, 1818, he started on foot, with a knapsack on his back, over the bleak hills and frozen ground. Owing to the extreme cold, which happened to set in about that time, the journey proved a very severe one, and to that he attributes his impaired hearing.

At Watertown, he obtained employment in the district school. Here, also, he entered a law office, and pursued his legal studies. At the end of three months, he obtained sufficient law business to enable him forever to relinquish the school room, and to continue his studies without further interruption. He completed them at Sacketts Harbor, in January, 1825, and took his license as attorney at law. He spent the two succeeding years in practising in the office where he finished his course. A part of the third year was spent in a journey through the southwestern states, with a vague notion that he would locate himself in a new country, and "grow up with it." He visited Gen. Jackson, and saw all the lions in his way. He found the country, however, too "new" for his taste, and returned to his father's house, exhausted in funds, and in feeble health. After recruiting himself to some extent, he finally located at Little Falls, Herkimer county, his present residence. He there devoted himself to the practice of his profession, with considerable success.

In February, 1828, he was appointed surrogate of Herkimer county, which office he held until 1837. 
In the winter of 1834 , his name was sent to the senate, by Gov. Marcy, for the office of circuit judge; but, owing to an apprehension that his defective hearing would interfere with the proper discharge of the duties, the nomination was subsequently withdrawn. On that occasion he received complimentary letters from all the democratic senators, assuring him that nothing but the said impediment had induced them to advise the substitution of another person.

During the spring of the same year, Gov. Marcy appointed him on the commission, with Messrs. Elisha Litchfield and Eli Noore, to investigate the subject of mechanical labor in the state prisons; also, the prison policy and discipline. After a most laborious investigation, a report and bill, both drawn up by Mr. Loomis, were submitted to the legislature, in 1835, on which the law of the year was based. This had the effect of subduing the prevailing excitement for several years, when the continual disregard of the regulations, by the executive officers of the prisons, caused the mechanical interests in the state to renew the complaint.

In the fall of 1836, Mr. Loomis was elected a representative in congress, and took his seat at the first session under Mr. Tan Buren's administration. During the long session of $1837-8$, he was a menber of the committee on private land claims, and his labors were so severe as to seriously impair his health. The following session he served on the committee on public lands, where he also found that there was work to do. While on the latter committee, he strenuously exerted himself to prepare the way for the sale of lands to actual settlers only, and at a very moderate price, believing then, as now, that all other sales are detrimental to the public interest. He also exerted himself in favor of postage reform, and the regulation of the franking privilege, and with this object he introduced 
many resolutions of inquiry into the existing abuses, and which had the effect of hastening the subsequent action of congress on those subjects.

On the 1st of January, 18+1, Mr. Loomis took his seat in the New York legislature, as a representative of Herkimer county. Here, entertaining strong convictions of the great evils of a public debt, and thinking that he perceived a strong tendency to create debts, and in many cases from selfish motives, it occurred to him that these tendencies might be lessened, if not entirely obviated, by preventing any public debt, unless sanctioned by the direct vote of the people themselves. In addition to giving his views through the press, on the 14th of January, 1841 , he introduced a resolution to amend the constitution, so as to restrain the legislature from borrowing money, or creating any public debt, except to repel invasion, suppress insurrection, or to defend the state in war, unless authorized by a direct vote of the electors, at a general election. This proposition was approved by most of the democratic papers in New York, and other states. Many of the editors kept it at the head of their columns for months. Although the resolution was not carried, yet its frequent repetition by him, during succeeding sessions, resulted, in the convention of 1846, of which Mr. Loomis was an active member, in its adoption.

Of the arduous labors of Mr. Loomis, as chairman of the judiciary committee, in the legislature, and of his eminent services as a member of the convention, and which seriously injured his health, our limits will not permit us to speak. It will be sufficient to say, that a more devoted public servant cannot be found.

We have thus seen that this youth, who, in a severe winter, and with a sad heart, left his home, with his knapsack on his shoulder, to seek a situation as a teacher, by adhering to his motto of " ne- 
ver give up," has overcome formidable obstacles, become an eminent lawyer, and filled some of the most honorable offices in the country, with credit to himself, and to the entire satisfaction of his constituents.

\section{THURLOW WEED.}

The early history of the newspaper press in Albany, is involved in obscurity. From a paper furnished (by Joel Munsell, Esq., of Albany) to the committee of the late printers' festival, held at Rochester, it appears that the first printing presses in $\mathrm{Al}$ bany, respecting which any authentic information can now be gathered, was established by Alexander and James Robinson, who came from New York for that purpose, about the year 1770, which, until then, was the only place in the colony where printing had been introduced. Their paper, called the Albany Gazette, was continued but for a few years, as, in 1776, the publishers joined the royalists in New York; and on the evacuation of that city by the British, they took refuge in Nova Scotia, at Port Roseway, where Alexander died in 1784, aged 42.

In May, 1782, Messrs. Solomon Ballantine and Charles R. Webster published the first number of a paper called the New York Gazetteer, or Northern Intelligencer. The office file of this paper was destroyed by the great fire of 1793 , and the only copies known to exist, are a few scattering numbers, preserved by the Rev. E. Westerlo, and presented by his son, Rensselaer Westerlo, Esq. The advertisement issued by the publishers, was unique, both as a specimen of literature and typography. The following is an extract: 
" To the Inhabitants of the CITY of ALBANY, and the ADJA CENT COUNTRY round about.

The great usefulness and many benefits arising from a weekly NEWSPAPER are so obvious, and universally known, that they scarcely need to be mentioned.

It points out to the Poor Man where to go and lay out his Penny to the best Advantage.

It brings Customers to the Mechanic's Shop.

It crowds the Merchant's store with Chaps!" \&c., \&c.

In 1784 , the paper was enlarged, and the title changed to the Albany Gazette, published by $\mathrm{Mr}$. Webster alone. The first number contains an extract from the city ordinances, for regulating the ferry-the first item of which is:

"FOR TRANSPORTING EVERY PERSON ACROSS, EXCEPT A SUCKING CHILD, 2 COPPERS."

And further on, conspicuously inserted, is the following advertisement:

"WG A VERY LIKELY YOUNG WENCH FOR SALE. Inquire of Philip Cuyler."'

The first regular bookstore, says Mr. Munsell, of which I can learn any thing, was that of "William Falconer \& Co., No. 4 Court street, opposite the Dutch church;" although, at the same time, Mr. Webster, the printer, was dealing, in a small way, in books and stationery, as were also the principal merchants, whose stock consisted principally of Bibles and school books, which were fantastically arranged, in their advertisements, with "Red China Tea Pots, and Tobacco Boxes." For instance, Daniel Hale has these two lines in juxtaposition in his advertisement:

Blank Books, Psalms, and Spelling Books, Pewter Dishes, Basons, Plates and Mugs.

In 1788, Mr. John Barber commenced the publication of the Albany Register, as a republican paper, Mr. Webster having identified himself with the federal party. Another paper, called the Federal Herald, was also published during the year, by 
Claxton \& Babcock. In 1796, a third paper, called the Albany Centinel, was published by Loring Andrews. It was continued ten years, when it passed into other hands, and was called the Republican Crisis. The Crisis was afterwards published in 1807, by Isaac Mitchell, and in 1809, by Croswell \& Tracy. In 1809, the Balance took its place, by Harry Croswell, at the end of which year it was discontinued.

In the spring of 1809 , the Gazette began to report the proceedings of the legislature. In 1812, a new democratic paper appeared, in opposition to the Register, called the Albany Republican, by Samuel R. Brown. In 1s13, Mr. Jesse Buel commenced the publication of the Albany Argus, semi-weekly, at $\$ 3$ a year. It was the organ of the Tompkins division of the democratic party. At the end of the half year, the subscription was 4000 , being a thousand greater than that of any other paper in the state. The Argus was first published daily in 1825, by Croswell, Barnum \& Van Benthuysen.

The first daily paper, however, was the Daily Advertiser, which was commenced in 1815 , by Theodore Dwight, and was discontinued in 1845 .

It was in 1828, that Thurlow Weed, Esq., commenced the Albany Evening Journal, as the organ of the anti-masonic party in the state of New York. $\mathrm{He}$ is, we believe, a native of the state of New York; and, by a reference to the biography of the Hon. James Harper, it will be seen that Mr. Weed is the architect of his own fortune, he having, some thirty years ago, been a fellow journeyman printer, (in the office of Jonathan Seymour,) with the great publisher, in New York city.

In April, 1818, Mr. Weed was united in marriage with Miss Catharine Ostrander, by whom he has had several children.

A few years ago, Mr. Weed, for the benefit of his health, traveled through a considerable portion of 
Europe. His letters from abroad were replete with interest, and contained much valuable information.

The writer never, to his knowledge, saw $\mathrm{Mr}$. Weed, or had any correspondence with him; but he can with confidence assert, that as a citizen, the conductor of the Journal is highly respected by the community among whom he dwells.

Mr. Weed is probably fifty years of age, and it is really wonderful that in these days of high-pressure party excitement, a political editor should so long survive. There are but few roses mingled with the many thorns which bestrew his path. Like a man placed in the pillory, a party editor is made the butt of all sorts of people, and doomed to be struck by every missile; and, aside from the necessary labor and anxiety which must ever attend so responsible a station, he is ever liable to have his conduct misrepresented, and his motives impugned, without being allowed the privilege of vindicating his own character. If, says an able writer, you would live in quiet-if you would die in peace, at a good old age, smother the first buddings of ambition, and "shun all connection with the political press."

The editorial career of Mr. Weed has been one of almost unparalleled success, in the annals of newspaper printing, having enriched his publishers, and secured to himself, by the office of state printer, which he held during Gov. Seward's administration, a comfortable competence. He is now one of the proprietors, as well as editor, of the Journal. Unlike many others who have risen from obscurity tó honorable positions, Mr. Weed has a heart capable of sympathizing with the unfortunate, and may be justly called-“"The poor man's friend." 


\section{CYRUS BEERS.}

There are few more remarkable instances of the triumph of perseverance over difficulties, than that afforded by the career of the Hon. Cyrus Beers.

He was born at Newtown, Connecticut, on the 21st of June, 1786, and is the son of Hannah and David Beers. Owing to the poverty of the family, Cyrus never received any school education, except at short intervals, in the winters, previous to his tenth year. In addition to this, his father was one of that numerous class who exercise no government over their children, so that his son was left entirely to himself, which proved a great disadvantage to him in after life. At the age of twenty-five, Mr. Beers married Miss Phebe Gregory, a sister of Rice Gregory, M. D., of Hobart, Delaware county. He had previously opened a store at the latter place, in which he had invested the avails of the hard earnings of many years of patient industry, amounting, probably, to $\$ 4000$. In a few months after his marriage, however, he lost the whole of his property by fire, and, with the best years of his life gone by, had to commence the world anew. It was a sad trial, and one which would have prostrated the energy of many. But he was not the man to "give up the ship;" so in good earnest he set to work, and in about five years he had realized nearly the full amount of his loss. But his troubles were not over. Being tempted into a lumber speculation, which he prosecuted for a considerable period, he, by a course of events which no human foresight could have guarded against, not only lost his own, but several thousands more, which he had procured on credit, together with ten years of incessant labor 
and anxiety. In addition to this, the busy tongue of slander was at work, and he had to endure the scoffs and sneers of those who had escaped similar misfortune. Thus it is, instead of "mourning with those that mourn," and whispering the blessed words of sympathy to the troubled and cast down, man is ever ready to insult the unfortunate. But,

Hope reigns eternal in the human breast;

and yet a third time did Mr. Beers brace himself up against the storm. He obtained a situation as clerk, at a dollar a day, out of which, for some years, he managed to support his family and educate his children. The assertion of holy writ, that " diligence maketh rich," he found true as ever, and by degrees the sunshine burst from behind the dark clouds, and Mr. Beers became one of the wealthiest men in Ithaca, New York, where he has for many years resided.

In November, 1838, Mr. Beers was elected a representative in congress. While in that body, he was truly a working, instead of a talking, member. When he took his seat, he saw that there was a great want of "good listeners," and while others were quibbling about trifles, and talking by the hour, upon abstract questions, he joined himself to the "bees," and rendered essential service to the country, by bringing the fruits of his valuable experience to bear upon questions of vital importance to the working classes. His impaired health, however, induced him to decline a renomination. He is, we believe, an extensive land holder, and his time, of late years, has been entirely devoted to the management of his estates. His plans are all laid with skill, and pursued with energy, and he has ever displayed the most unwearied perseverance in pursuit of laudable objects, under difficulties which would have borne down many other men How true it is, that talent, when thus allied with 
patient energy and persevering industry, will not fail to insure ultimate success to its possessor.

Mr. Beers has two sons, the eldest of whom was very recently a member of the New York state senate-the other has obtained considerable celebrity as a financier.

\section{SOLOMON SOUTHWICK.}

Left, at the age of twelve years, a destitute orphan, without friends or resources of any kind, other than such as nature had bestowed upon him, in the inappreciable blessing of a sound and vigorous constitution, he commenced the work of self-education in the stern school of adversity, and progressed, step by step, with an unfaltering determination, and an unyielding energy, until he found himself in the higher walks of honorable usefulness.

Solomon Southwick was born at Newport, Rhode Island, on the 25th of September, 1773. His father was one of the earliest and most efficient champions in that gallant struggle for the rights of the colonists, which eventuated in the war of the revolution. His son, the subject of this sketch, commenced his career while yet a mere boy, as cook for a fishing company bound for Cape Cod. After enduring, for several months, the hardships and privations incident to such a station, he returned to Newport, and apprenticed himself to a baker, in his native town. He afterwards went as a common sailor, on board a coasting vessel, when he apprenticed himself in a printing establishment in the city of New York. From thence he was transferred, as a journeyman in the office of the Albany Regis- 
ter, then conducted by his brother-in-law, Mr. Barber. On the death of the latter, in 1808, Mr. Southwick succeeded to his interest in the paper. He continued in charge of the Register for nearly thirty years, during which period he held many honorable offices in the state. He subsequently took charge of the National Democrat. During the prevalence of the anti-masonic excitement, he established and conducted the National Observer, the prominent organ of anti-masonry. He was soon afterwards nominated as the candidate of that party, for the chief magistracy. Failing of success, however, and disgusted with the vexations of political strife, he withdrew from public life, and wisely sought happiness in the domestic and social circle. The remainder of his life was devoted to study and contemplation, to the welcome enjoyments of the family fireside, and to the dissemination of moral, religious, and intellectual truth.

Suddenly, in the midst of his usefulness, and in the full maturity of his intellectual powers, he was arrested by the hand of death, on the 18th of November, 1839. He was attacked by an affection of the heart, which, in about fifteen minutes, terminated fatally. 
? 


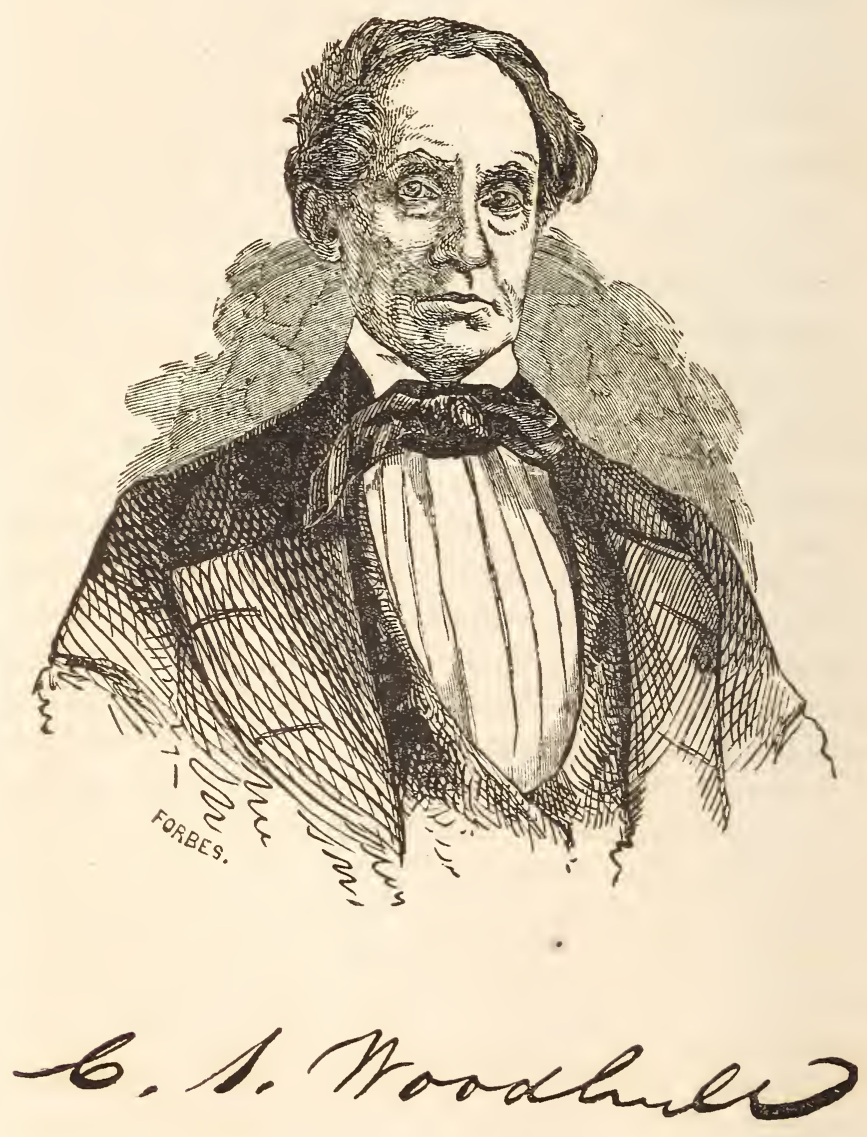




\section{CALEB S. WOODHULL,}

Is a resident of the city of New York, and a distinguished member of the bar of that city. He was born on the 26th of February, 1793, at Miller's Place, a beautiful village in the town of Brookhaven, Long Island. Of the family from which he is descended, a passing notice will here be given.

It being one of the purposes of this work to record and illustrate such ancestral reminiscences of the biographical subject, as will be gratifying to the descendants, and interesting to general readers-it will not, therefore, be out of place, if a few pages be devoted to a narrative sketch of Mr. Woodhull's ancestors, who have attained a high social positionand some of them distinguished historic mentionin the annals both of this country and Great Britain; and of whom a geneological record has been preserved, registering their line of descent from the time of William the Conqueror. In this countrywhere no law perpetuates titled or ancestral distinctions to a privileged few, where there is no nobility, except for those who win and maintain it by their own efforts; where no honors are hereditary, but belong only to those who are successful in the free strife to attain them-it will not be supposed that any one would claim consideration for himself, in consequence of the merits of those who have preceded him. Here, where the accident of birth does not confer office or power, he who may have passed through life with honors from his fellow men, must have risen to his position by virtue of his own merits and talent. Whether born of obscure or eminent parents, every person must be the architect of his own fortune. An humble origin is no bar to one's elevation in life-neither does distinguished 
birth secure to one either wealth, honor, or respect. In giving, then, an account of the ancestors of the subject of this memoir, no other object is held in view than that of illustrating the deeds of one who was a prominent actor in the early scenes of the American revolution-of rescuing from oblivion some of the untold events of our history, and of placing on the convenient and permanent record of print, a family chronicle; which, whatever of interest it may possess for the general reader, will also be of inestimable value to the very numerous and highly respectable living connexions and descendants, of the ancestry thus preservingly chronicled.

From a register of the family, it appears that the original progenitor of the Woodhulls was Walteras Flanderemis, who accompanied William the Conqueror, in his invasion of England, in the year 1066. It is probable, as his name would seem to indicate, that he was a Flemish soldier, and also that he was a person of some consideration, for his son Walter was made baron of Wahull. The estates and title of the barony regularly descended from father to son, until John, in the sixth generation, dying without issue, was succeeded by his sisters-first Rosea, and then Agnes-the latter of whom, having been married to Robert Bassingham, left her son John as heir, who became baron of Wahull. In the seventeenth generation, the inheritance fell in a collateral branch of the family, whose name was Nicholas Wodhull, and who changed the title to that of the baron of Wodhull. Thenceforward the succession continued in the line of the Wodhulls.

The first American ancestor, of the family in this country, was Richard Wodhull, a great-grandson of Nicholas, the twenty-second baron of Wodhull, who lived at about the close of the sixteenth century. Richard Wodhull was born at Therford, Northamptonshire, Sept. 13, 1620. His zeal in the 
cause of English liberty induced him to join the party of Cromwell, whose probable downfall, or at least uncertain fate, may have had an influence in causing him to leave his country, and to seek the security and freedom of an abode in the western world. The precise time of Mr. Wodhull's arrival in this country is not known; but, in 1655 , or 1656 , he appears as one of the original purchasers and settlers of the plantation of Setauket, on Long Island. This plantation, which extended across the island, was, on the possession of New York, by the English, in 1664, called Brookhaven, while the name of Setauket was confined to the village of the first settlement. It is supposed that he arrived in this country in 1648 , and his name was associated with the settlers of Jamaica. In 1659, Setanket sought the protection of the general court of Hartford, which appointed Mr. Wodhull the first of two magistrates over the plantation. His skill in the art of surveying, and his knowledge of the principles of law, and legal forms of business, rendered his services particularly valuable to the colonists, and his name is found associated with all the more important transactions of the town. He was entrusted to purchase the southern part of the town, on behalf of the people. A letter is now in possession of his descendants, written to him, in 1687, by his kinsman, Lord Crew, bishop of Durham, who gives some account of the relatives he had left behind him. He died in 1721, aged eighty-eight. His name was Nicholas Wodhull. Lord Crew also presented to him the crest and arms of the family, whose heraldic signs are emblematic of a long catalogue of chivalric virtues. Michael Wodhull,-an ingenious writer, and the translator of Euripides, was educated at Brazen Noze college, and died at Therford, his native place, in 1816 , at the age of seventy-six.

Mr. Wodhull died at Setauket, in 1690, leaving his eldest son Richard heir, who was also a magis- 
trate. His other son, Nathaniel, who died without issue, and his daughter Deborah was married to Capt. John Lawrence, of Newtown.

The second Richard was married to Temperance, daughter of Rev. Jonah Fordham, of Southampton. During his life time the orthography of the name was changed to that of Woodhull. He died in 1699, leaving his children, Richard, Nathaniel, John, Josiah, Dorothy and Temperance. John settled at Wading river, and had issue-John, whose children were, James, Josiah, John and William; the latter of whom married Elizabeth, daughter of Phillips Roe.

The third Richard married Mary, daughter of John Homan, of the same town, and died in 1767, leaving Richard, Mary, John, Nathan, Stephen, Henry, and Phoebe. Mary was married to Jonathan Thompson, and Benjamin F. Thompson, author of the History of Long Island, is their grandson.* Nathan married Joanna Mills, and died a merchant, at Setauket, in 1804, leaving Nathan, $\mathrm{Na-}$ thaniel, David, Sarah, and Phoebe. Nathan graduated at Yale college, in 1775 , at the age of twentythree. He married Hannah, daughter of Stephen Jagger, of Westhampton, and settled as a farmer at Southold. Subsequently he studied theology, and was ordained in that parish, in April, 1785, but removed, in 1789, to Newtown, where he died, pastor of that church, in March, 1810. Nathaniel married Rebecca, daughter of Joseph Brewster, and their children were, Nathan, Samuel, Richard, Rebecca, and Hannah. David married Irena, daughter of Rev. Noah Wetmore, and died at Newtown. Sarah was married to Selah Strong, a merchant, of New York, and their children were, Benjamin, James,

* To the very excellent work of Mr. Thompson, which is an invaluable contribution to the history of New York, and of our country, we are indebted for the princioal materials of the sketch of Mr. Woodhull's ancestors. 
Henry, Julia, Anne, and Charlotte. Phoebe was married to Jacob Van Brunt, and their children were, John and Sarah. Stephen, fourth son of the third Richard, married Hannah, daughter of Abraham Cooper, of Southampton, and their children were, John, Cooper, Hannah, and Sarah. Of these, John married Catharine Smith; Hannah was married to Ebenezer Smith; and Cooper married Sarah, daughter of Dr. Gilbert Smith.

The fourth Richard married Margaret, daughter of Edmind Smith, of Smithtown, and was a very useful man, having, as had also his ancestors, filled during the greater portion of his life, the office of magistrate. He died in 1788, leaving Susanna, Richard, Mary, Adam, and Abraham. Mary was married to Amos Underhill, and their daughter Margaret to Oliver Coles. To Abraham was devised most of his father's estate at Setauket. He was for many years a magistrate, and from 1799 to 1810 , first judge of the county. During the revolution, a secret correspondence was for a long period carried on between him and Major Tallmadge, for the purpose of affording important aid and information to Gen. Washington. He was married first to Mary, daughter of Obadiah Smith, of Smithtown; and second, to Lydia Terry. He died in 1826, leaving Elizabeth, Mary, and Jesse; the latter of whom died in 18t0, leaving the original ancestral estate at Setauket, to his son, who is still the occupant.

The fifth Richard married Sarah Miller, of Miller's Place, and died in 1774, leaving Richard, Sarah, Dorothy and Julia.

The sixth Richard M. Woodhull, was a merchant in the city of New York, where he died. His only son, Maxwell Woodhull, is a lieutenant in the navy.

General Nathaniel, a distinguished actor in the scenes of the revolution, was a great-grandson 
of the first American ancestor. His father, Nathaniel, was the second son of the second Richard, and he settled upon lands devised to him at Mastic, in the south shire of Brookhaven. He married Sarah, daughter of the second Richard Smith, of Smithtown, and died in 1760, leaving Hannah, Temperance, Nathaniel, Dorothy, Sarah, Richard, Ruth, Jesse, Juliana, Deborah, and Ebenezer. Of these, Jesse and Ebenezer settled in Orange county, New York, where they left families of children. Richard, born in 1729, graduated at Yale college, in 1752 , and was for several years tutor in that institution. He had a high reputation for his attainments in classical learning, and was particularly distinguished in the department of mathematics. His adoption of the theological opinions of the Rev. Robert Sandeman, led to his separation from the college. He married first, Elizabeth Mix; and second, Rebecca Carr, of Boston. His only daughter was married to Jehu Brainard, Esq., of New Haven. He died in 1797.

General Nathaniel Woodhull was born at Mastic on the 30th of December, 1722. His early life was passed with his father, in the cultivation of the farm, which he afterwards inherited, and his education was adapted to fit him for the active duties of life. He was married, in 1761 , to Ruth, daughter of $\mathrm{Ni}$ coll Floyd, and sister of Gen. William Floyd.

During the French war, as it is termed, he entered the army, and, having received the commission of major, in the provincial forces of New York, he was engaged under Gen. Abercrombie, in his daring assault on Ticonderoga, in the year 1758. On the 27th of August, a combined attack on the fort was made both by land and water, and an important command of the forces, in boats, was cornmitted to Major Woodhull, with orders to receive the fire of the fort without returning it, until he should have approached to within close quarters. This order 
was executed with bravery and skill, and contributed materially to a reduction of the fort, which soon surrendered with its large armament and stores, and nine armed vessels of war. The following year he was actively engaged in the campaign, and in 1760 was promoted to the rank of colonel, commanding the third regiment of New York provincials. In the same year he marched under General Amherst against Montreal; and, on the final reduction of Canada, and the capitulation of the French general on the 8th of September, he returned with his troops to New York, and retired to private life, on his farm at Mastic.

Col. Woodhull was not suffered to remain long in the quiet shades of his retirement. He was soon called forth to take an active part in the eventful scenes of the contest now begun between the colonies and Great Britain. In December, 1768, the assembly of New York passed an unaninıous resolution, that no tax could or ought to be imposed on the colonists, except by their own consent; that the privileges of the legislature could not be annulled, abridged, or suspended, and that they had a right to consult with the other colonies, in defence of their own liberties. In consequence of this bold position, the governor, Sir Henry Moore, dissolved the assembly, on the $2 \mathrm{~d}$ of January, 1769. This arbitrary act aroused the spirit of the people, and an election for new members took place in the spring of that year, at which Col. Woodhull and William Nicoll were returned from the county of Suffolk. For the following six years, during which the colonists acknowledged the royal authority, Col. Woodhull remained a member of that body, and was constant in his devotion to the rights of the people, and his opposition to the encroachments of British usurpation.

Col. Woodhull was next elected a member of the convention which met in the city of New York, on 
the 10th of April, 1775-6, to choose delegates to the continental congress.

On the 22d of May, in the same year, the first provincial congress of New York assembled in the city of New York, and, from the time of its organ. ization, practically asserted and maintained its right to the entire sovereignty, and in effect suspended the royal authority. Col. Woodhull was a member of this body, and was at the head of the Suffolk delegation. On the 22d of August, the militia of the colony having been organized by the congress into brigades, each of which to be commanded by a brigadier-general and a major of brigade, Col. Woodhull was appointed brigadier-general of the brigade composed of the militia of Suffolk and Queens county. On the 28th of the same month, he was elected president of the congress. This body not deeming itself clothed with power to erect a new form of government, entirely independent of all foreign control, in accordance with the request of the continental congress, on the 31st of May, 1776 , called on the electors to choose a new congress, or give to the present one enlarged powers. The new powers were given, and the second provincial congress assembled at White Plains, on the 9th of July, when Gen. Woodhull was again chosen president. In the continental congress, the New York delegation, fettered by instructions given twelve months previously, when a hope of reconciliation was yet cherished, had been unable to vote for the declaration of independence. Accordingly, the first act of the provincial congress was an unanimous adoption of the declaration on behalf of the people of New York. On the next day the congress assumed the title of "The Representatives of the State of New York." The convention was soon after transferred to Harlem, and on the 10th of August, General Woodhull obtained temporary leave of absence, in order to attend to some affairs 
at horne. Abraham Yates was made president pro tempore, during the absence of Mr. Woodhull.

Gen. Howe having landed on Long Island, on the $22 \mathrm{~d}$ of August, and two regiments of the Long Island militia, under Cols. Smith and Remsen, being within the lines at Brooklyn, the convention, on the 24 th, ordered Gen. Woodhull, with one-half of the Suffolk regiment and the militia of Queens county, to advance into the western part of the latter county, and deprive the invading foe of supplies, by removing the cattle and grain in the vicinity, and thus compel the British to abandon the island. These orders were immediately conveyed by express to Gen. Woodhull, who at once repaired to Janaica, which place he reached on Sunday, the following day. Without delay he apprized the convention of his arrival, and awaited the assembling of the troops he was to command. But he was doomed to meet with delay and disappointment. The convention was fully aware of the insufficiency of the force he might be able to raise. The inhabitants of Suffolk county, capable of bearing arms, were almost entirely occupied in preventing or resisting depredations along their extensive line of exposed coast. In Queens county, a majority of the people were tories, and in the preceding year, by means of arms obtained from the Asia man-of-war, had prevented an election of delegates to the provincial congress; and a military intervention, under authority of the continental congress, had been established, to deprive the tories of their weapons, and to secure to the whigs the freedom of election. Such being the condition of the country, but few troops could be-raised, notwithstanding the resolutions of the convention required the officers of Queens county, to call out all the militia of that county, together with the troop of horse; and, if necessary, to call on the troop of horse in Kings county to join them. Accordingly, on the 26th, the day after his 
arrival at Jamaica, Gen. Woodhull having mustered his troops, had obtained but one hundred men from Suffolk, and forty from Queens county, and but fifty of the troops of horse from Queens and Kings county. With this command, small as it was, he did not hesitate to advance immediately, and attempt, with such unequal means, the execution of his orders. The convention, aware of the inefficiency of this force, had, on this day, applied to Gen. Washington to allow the regiments of Cols. Smith and Remsen, to join their brigade under Gen. Woodhull. Gen. Washington replied that he would give immediate orders to that effect; and, on the same day, the 26th, this answer was communicated to Gen. Woodhull, by the convention, with the expressed anticipation that the letter and the reinforcement would reach him at the same time. Under the supposition that the two regiments had joined him, the convention gave him instructions to take an advanced position, "for preventing the incursions and depredations of the enemy." It has been supposed, however, that these instructions did not reach him until the following day, after the battle of Long Island, when he had retired to $\mathrm{Ja}$ maica. The promised regiments were not sent to Gen. Woodhull; Washington and his officers subsequently decided that they could not safely be spared from the lines. Gen. Woodhull was not, however, made acquainted with this change of determination.

He accordingly advanced with his small command, and momentarily anticipating reinforcements, approached to within about six miles of the enemy's camp, and to within two miles of some of his scouts of light horse. On the following day, he had succeeded in driving back about eleven hundred cattle, and had placed a line of guards and sentinels extending from the north to the south of the island to prevent the return of the cattle, and to 
cut off the communication of the tories with the enemy. On the morning of this day, the $27 \mathrm{th}$, the enemy gained the battle of Long Island, and parties of his horse making incursions into the country, General Woodhull found it necessary to retire to Jamaica with his force, reduced to less than one hundred men.

Though, on the morning of the 2sth, his force was reduced to ninety men, and constantly diminishing, and though he had abandoned all hope of the reinforcements, on account of the interruption of the communication by the enemy, still, actuated by a high sense of honor. and in accordance with the ideas of military obedience which he had formed in the strictest school, Gen. WVoodhull resolved to maintain his post, and, as far as possible, carry into execution the orders of the convention. Accordingly, on this morning he succeeded in getting back within his own lines three hundred more cattle; and, if pressed by the enemy, was intending to drive them, together with those assembled on the preceding day, back into the woods, as he retired. Still, he resolved not to make a final retreat until he should have heard from the convention. He therefore sent his troops back to a position four miles east of Jamaica, to await further orders, while he himself remained in the village till afternoon, in momentary expectation of a message from the convention, to which he had sent a messenger for instructions, whether to return and take his seat as president of that body, or to remain in his command. On this day he dined at Jamaica, with Mr. Hicks, mayor of New York, and then, with one or two companions, set out to join his troops. A shower of rain coming up, they took shelter at Carpénter's tavern, two miles east of Jamaica. While here, a squadron of British dragoons, and a party of infantry, piloted by a tory named John Cornwall, approached the tavern, when the inmates fled, and 
concealed themselves in a corn field and under the barn. Gen. Woodhull, with the hope of reaching his command, sprang for his horse, which was under the shed, and, while in the act of unhitching the bridle, was taken by Lieut. Huzzy, of the dragoons. He immediately surrendered his sword; when this officer roughly commanded him to say: "God save the king!" The general replied: "God save us all!" On which this brutal lieutenant cowardly and cruelly attacked him with his swordseverely wounding him in the head, and mangling one of his arms from the shoulder to the wristand would have slain his prisoner, had not another officer, said to have been Major Delancey, arrested his savage violence. It is a singular circumstance, that this squadron was commanded by Major Crew, the general's nearest relative of the English branch of the family; and that in consequence of the barbarous treatment of Gen. Woodhull, he is said either to have resigned his commission in disgust, or to have obtained leave to return to England.

The general was taken to Jamaica, where his wounds were dressed; and on the next day, together with eighty other prisoners, of whom Colonel Troup, of New York, was one, was confined in a vessel at Gravesend, which had been used to transport live stock for the arny. Through the intercession of an officer, more humane than the others, he was removed to a house in New Utrecht, where he was allowed to receive medical attendance. $\mathrm{He}$ now sent for his wife, with a request that she should bring all the money which she could procure; which he afterwards distributed among the suffering American prisoners. Soon afterwards he suffered amputation of the arm, which issued in a mortification, that terminated his life, September 20 th, 1776 , in the fifty-fourth year of his age. His remains were removed by his wife, and interred at his residence, in Mastic. He left only one child, 
who was married first to Henry Nicoll, and afterwards to the late Gen. John Smith.

Gen. Woodhull was as much distinguished for his private and domestic virtues, as for the zeal and talents displayed by him in the cause of his country. His death spread a gloom over the state, and the inhuman treatment he received, aroused a strong spirit of indignation, and served to alienate still more the people from a country whose officers were capable of such acts of cruel barbarity.

Caleb S. Woodhull is the grandson of John Woodhull, the second son of the third Richard Woodhull. John married Elizabeth, daughter of William Henry Smith, of Mastic, and, in 1740, settled at Miller's Place, where, fifty-four years afterward, he died, at the age of seventy-five, leaving nine children, William, John, Caleb, Merrit S., Henry, James, Elizabeth, Gilbert, and Jeffrey. Caleb, Henry, and Gilbert, the latter of whom was a merchant in New York, died without issue.

William became a clergyman, married Elizabeth, daughter of William Hedges, and was settled at Chester, New Jersey, where he died, leaving Temperance, Mary, Mehetable, William, Jeremiah, Elizabeth, John, Hannah, Henry, and Caleb.

His brother John married Miss Spofford, of Philadelphia, and was settled first as the minister of Lancaster, Pennsylvania; and next at Freehold, New Jersey, where he died; leaving Spofford, John and Gilbert.

His brother James, who was a merchant in New York, married Keturah, daughter of Selah Strong, by whom he had Selah S., (who became a clergyman, and one of the professors in the theological seminary, New Brunswick, New Jersey, where he died,) and Elizabeth, who was married to George Griswold, merchant of New York. His sister Elizabeth was married to Samuel Hopkins; and the youngest brother, Jeffrey, married Elizabeth Davis, 
and died in 1839, leaving William, Elizabeth, and Smith.

Merrit S., the fourth son of John, was the father of Caleb S. Woodhull. He inherited the patrimonial estate at Miller's Place, and became an extensive agriculturist. For many years he was a justice of the peace and magistrate, and such was his love for peace among his neighbors, that it was his usual practice first to officiate as arbitrator or peace-maker between the contending parties, and then to issue process only when all efforts at reconciliation had entirely failed. He died of typhus fever, after an illuess of eight days, on the 29th of November, 1815, at the age of sixty-seven. His widow, whose name was Mary, and the daughter of Samuel and Hannah Davis, of Brookhaven, survived him many years, and died on the 26th of March, 1840, at the age of eighty-three.

Caleb S. Woodhull, their third son, was born in 1793, and received the rudiments of his early education at the village school, in Miller's Place. He afterwards studied with the Rev. Herman Daggett, who resided at Middle Island, in the town of Brookhaven, and with him pursued a course of classical studies, preparatory for college. From thence, in 1808 , at the age of fifteen, he entered the freshman class of Yale college, then under the presidency of the late Dr. Dwight, and in 1812, graduated with the honors of his class.

After leaving college, Mr. Woodhull took charge for a few months, of the village school in which he received the first principles of his education. In 1814, he commenced the study of law, in the city of New York, with George $W_{\gtrless}^{\tau}$. Strong, a lawyer of great eminence, whose brother, the late Thomas $\mathbf{S}$. Strong, of Brookhaven, first judge of the county of Suffolk, was the father of the Hon. Selah B. Strong, now one of the justices of the supreme court of this state. Mr. Woodhull was admitted to practice in 
1817 , and he has pursued the profession of the law to the present time.

His professional studies were interrupted at their commencement, by the events of the late war with Great Britain. In the fall of $1 \mathrm{S14}$, the city of New York was threatened with an invasion, by the cooperation of the enemy's forces, advancing in two columns-one by the way of Long Island sound, and the other by the way of Sandy Hook. On this occasion he entered the service of his country, as a private, in the militia, and was engaged on a tour of arduous duty, for the term of three months, during the remainder of the campaign. He still continued in the militia service, until after the war, and held various commissions, chiefly in the general staff, until 1830, when, tired of the idle parades in time of peace, and convinced of the utter inutility of the militia system, as then conducted, he resigned his commission. At that period he recommended and urged the reorganization of the militia substantially in accordance with the system which has recently been adopted.

Mr. Moodhull is attached to the whig party, and has exercised an important influence in the councils of his political friends. At the charter election of the spring of 18.36 , he was chosen to represent the second ward in the common council, and was continued by his constituents a member of that body for eight successive years. For the first three years he was a member of the board of assistant aldermen, for two of which he was chosen president of that body. In 18.39, he was chosen a member of the board of aldermen, and was annually reëlected to that office for five years in succession. In the year 1843, when his party was in power, he was chosen president of the board of aldermen, and of the common council, and, during the absence of the chief executive, was the acting mayor of the city during that year. 
Mr. Woodhull was, during nearly the whole period of his membership of the common council, chairman of the law committee, and in this capacity many of the most important affairs of the city came before him for especial examination, and many measures of serious import were either defeated, or recommended and carried into effect, by his influence. Among these was one, in 1840, proposing compensation to the members of the common council. He reported against this measure, and it was lost. At the same time, he recommended the reorganization of distinct executive departments, a measure of vital importance to the welfare of the municipal government, and one whose adoption both parties have since repeatedly urged. Another measure of the utmost consequence to the sitizens, was effected by Mr. Woodhull. It had become the practice of the city government, in violation of the city charter, to introduce improvements or changes in regard to streets, public squares, and other matters, involving heavy expenditures, to be paid by taxes, and specific assessments on estates, supposed to be benefitted, without the knowledge of the proprietors, some of whom had been overwhelmed with ruin. A resolution to arrest this practice, and require notice of contemplated improvements to be published, was introduced by David Graham, Esq. This resolution having been referred to the law committee, Mr. Woodhull made a very able report on the subject, and, by the aid of his efforts, the present system was established-resulting in the greatest benefit to the city.

In $1844, \mathrm{Mr}$. Woodhull was chosen by the friends of Mr. Clay one of the presidential electors for this state, and he received the highest number of votes given, with the exception of Hon. John A. Collier, who was one of the electors at large.

In politics, the views of Mr. Woodhull are broad and libesal, and he was never known to betray the 
confidence of his friends, or forfeit the respect and esteem of his political opponents. While in the common council, he was regarded, on both sides, more as an impartial judge than as the advocate of a party. His talents, sound judgment, and integrity of purpose, have secured to him the highest confidence of his political friends, who have repeatedly urged him to accept of nominations to higher positions, which his professional engagements and love of retirement have induced him to decline.

Mr. Woodhull, in 1919, married Lavinia Nostrand, who died within a few months after her marriage. In 1830, he married Harriet, daughter of Abraham Fardon, of the city of New York. By this marriage he has three children-two sons and one daughter.

Mr. Woodhull had four brothers and one sister. The eldest, John, to whom was devised the patrimonial estate at Miller's Place, was an active and enterprizing farmer. He held, for many years, the office of brigadier-general, and died July 21 st, 1837.

His widow now resides on the estate of her late husband, and has recently much improved and ornamented the adjoining grounds.

Samuel Woodhull, the next in age, was a merchant in the city of New York, and died May 17th, 1834, on his return passage from Europe-whither he had been for the benefit of his health-on board the ship Bristol.

Charles, the fourth brother, was a farmer, residing in his native village.

His sister Maria was married to Samuel Hopkins, a wealthy farmer, in the town of Brookhaven, where she now resides.

Albert Woodhull, the youngest, is the leading partner in the firm of Woodhull \& Minturn, in the city of New York, who are proprietors of the well known Liverpool line of packets, to which belong the splendid ships, Queen of the West and Constitution. 


\section{WILLIAM SAWYER.}

There are few men more respected for their sterling virtues, than the Hon. William Sawyer, member of congress from the fifth congressional district of Ohio. He was, during a considerable portion of his life, a blacksmith. He was not, however, one of that class who, while working with their hands, neglect their heads. On the contrary, when wielding the ponderous hammer, the mind of Mr. Sawyer was employed in deep reflection, and he acquired a habit of accurate and thorough investigation. He was not satisfied with superficial attainments, but explored the foundation and first principles of every thing. His leisure hours were spent in reading the lives of eminent men, both of ancient and modern days, and he observed the astonishing acquirements which they made by the ardent attachment and intense industry with which they cultivated science. He saw that it was by no secret magic that they attained to distinction and favor-but that it was by patient, untiring perseverance. In thus contemplating the character of these men, and their eager love of learning, he made no inconsiderable proficiency in many branches of practical knowledge.

Mr. Sawyer does not attempt to figure as an orator. When he speaks, you hear plain common sense. In his speeches there are no rhetorical flourishes, but he strikes home at once.

It is worthy of note that Andrew Kennedy, another practical member of congress, was once an apprentice of Mr. Sawyer's. May such men be multiplied. 


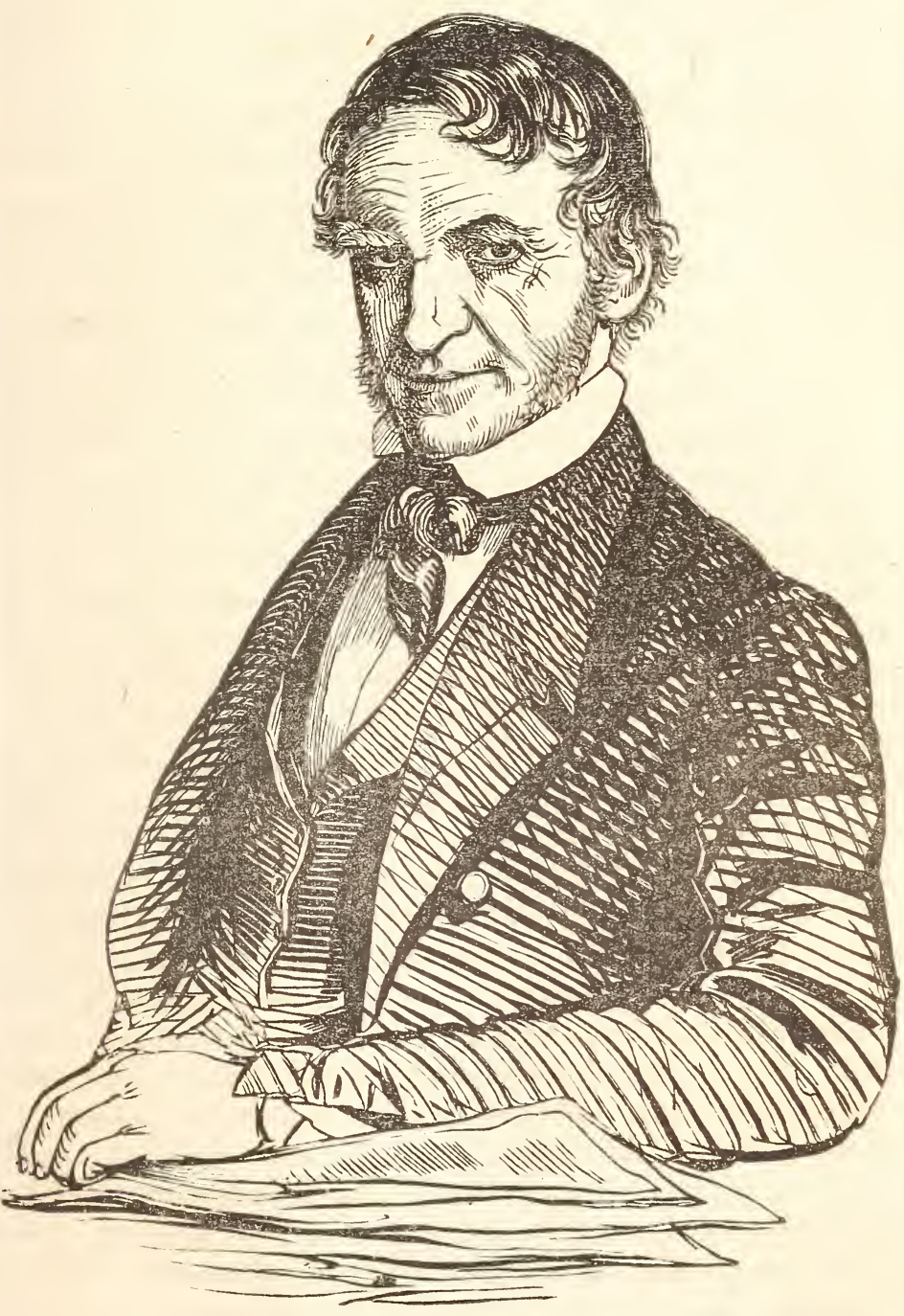

WILLIA M A W Y R . 



\section{JOHN BANVARD.}

There was, says Howitt, a young lad of fifteena fatherless, moneyless youth-to whom there came a very extraordinary idea, as he was floating for the first time down the noble Mississippi. He had read in some foreign journal that America could boast the most picturesque and magnificent scenery in the world, but that she had not yet produced an artist capable of delineating it. On this thought he pondered and pondered till his brain began to whirl; and as he glided along on the smooth surface of the river, gazing with wonder and delight upon the ever varied and beautiful shores, the boy resolved within himself that he would take away the reproach from his country-that he would paint the beauties and sublimities of his native land.

Some years passed away, and still John Banvard - for that was his name-dreamed of being a painter. What he was in his waking, working moments, we do not know; but, at all erents, he found time to turn over and over again the great thought that haunted him, till at length, ere he had attained the age of manhood, it assumed a distinct and tangible shape in his mind, and he devoted himself to its realization. There mingled no idea of profit with his ambition; and, strange to say, we can learn nothing of any aspirations he may have felt after artistical excellence. His grand object, as he himself informs us, was to produce for his country the largest painting in the world. He determined to paint a picture of the beautiful scenery of the Mississippi, which should be as superior to all others, in point of size, as that prodigious river is superior to the streamlets of Europe-a gigantic idea! which 
seems truly kindred to the illimitable forests and vast extent of his native land.

We will now say something of his eventful and romantic life; which, with its hardships, disappointments and privations, had fitted him for the accomplishment of his herculean undertaking. He was born in the city of New York, where he received a good education, and is descended from an old French family. His grandfather was driven out of France by the bloody sword of persecution, during one of the revolutions of the country, and fled to Amsterdam, in Holland. From thence he sailed to America, bringing with him little else but the heraldic honors of his family, for the Bon Verds (corrupted by the patois of the country to Banvard) were of highly respectable lineage. The coat of arms patented the family by the government, with the large antique silver seal, is now in possession of Rev. Joseph Banvard, brother to John, who is pastor of the Harvard Street church, Boston. Our hero showed the bent of his genius at a very early age. Being of delicate health in childhood, he was unable to enjoy the active, out-door sports of other boys; and, accordingly, he amused himself by drawing and painting, for which he exhibited decided talents, by becoming quite an accomplished draughtsman while yet a mere lad.

While his more favored brothers were in the open air, at play, he sometimes would be in his room projecting some instrument of natural science-a camera obscura, or natural microscope. He once came very near losing his eyesight, by the explosion of a glass receiver, in which he was collecting hydrogen gas. His room was quite a laboratory and museum. He constructed a respectable diorama of the sea, having moving boats, fish, and a naval engagement. He saved the pennies that were given him, not spending them in toys, or sweetmeats, as most youths would, and bought some 
types for a wooden printing press, of his own construction, and printed some handbills for his juve. nile exhibitions, which were quite genteel specimens of typography. The child was truly the father of the man in this, as in so many other cases, but he had much to pass through before the promise of the boy could be developed in the accomplishments of the man, as the sequel will show.

Young Banvard evinced a great taste for poetry, at which he early began to try his versatile genius. He wrote some very pretty verses when he was about nine years of age. He has continued occasionally to amuse his leisure hours in this way up to the present time-and several of his poetical productions have recently appeared in the newspapers. His poem of the White Fawn, which he recites to his audiences, in illustration of a scene in his beautiful picture of the Mississippi, certainly stamps him a poet of no ordinary abilities.

When Banvard was about fifteen years of age, his family met with a severe reverse of fortune. His father lived just long enough to see his property, collected by frugal industry and perseverance, swept away from him by the mismanagement of an indiscreet partner, and his family turned houseless upon a pitiless world. John then went to the west, poor and friendless, and far away from his mother, brother and sisters, and those he held dear. He arrived at Louisville, Kentucky, sought employment, and procured a situation in a drug store-but this did not suit his taste. Instead of making pills, his employer would often find him with a piece of chalk or coal, sketching the likenesses of his fellow clerks upon the walls of the rooms, where they were putting up medicines. His employer told him he thought he could make better likenesses than he could pills. John thought so too, and so "threw physic to the dogs," and left the druggist.

The next we find of Banvard, he is in the vil- 
lage of New Harmony, on the Wabash river, where, in company with three or four other young men, he "got up" some dioramic paintings, fitted them up for public exhibition, in a flat-boat which they built for the purpose, and started off down the Wabash, with the intention of "coasting" that river into the Ohio, and so down the Mississippi to New Orleans-thus exhibiting to the sparse populatirn of the wilderness, specimens of the fine arts, at the same time replenishing their exhausted funds. This proved to be a very unfortunate speculation. The capital of the company gave out before they were able to complete their plans, and they left port with their boat in an unfinished condition, calculating to finish it with their first proceeds, they having invested their last few dimes in a supply of bacon, corn, meal, and potatoes-but fate conspired against them. The river was low, and none of them had ever descended the Wabash; consequently, they were ignorant of the channel, lodged on the sand bars, and hung on the snags until they exhausted their scanty supply of provisions. They at length found themselves fast on a sand bar, and down to their last peck of potatoes at the same time. They labored hard all day to get out of this predicament, but without success; and, having roasted their last potatoes, they went to bed, or, rather, to bench, for their money gave out before they had procured bedding, and they had to content themselves with the softest plank of their seats for their slumbers. Next morning they were up before the sun, with their spirits refreshed by a night's repose, but without any breakfast; they jumped into the water, with their rails went stoutly to work again, to force their boat over the bar. Over exertion, together with being in the water too long without food, brought a severe fit of ague upon Banvard. The bar upon which they were fast was called the Bone bank bar, as immediately oppo. 
site, on the shore, the bank of the river was full of organic remains. Some of the large bones were then protruding out of the side of the bank, in full view. As Banvard lay on the soft sand of the bar, as it was more comfortable than the hard plank of the boat, his head burning with the fever, and his limbs racked with pain, he looked at these gloomy relics of an antediluvian race, and felt as though his bones would soon be laid with them. But at sunset the rest of the company got the boat over the bar, took Banvard aboard, and landed in the woods, all nearly exhausted. Food was as scarce here as it was upon the bar, and all hands went supperless to bed. Next morning they started early, not intent on exhibiting specimens of the fine arts, but on obtaining something to eat, as by this time they were nearly half starved. But the contrary winds landed their luckless craft on Wabash island, which was uninhabited. Here, fortunately, they found some pawpaws, and they all feasted voraciously on them, except Banvard, who was too sick to eat any thing, and who lay upon one of the benches burning with a violent fever. Next day they sent their handbills down to the village of Shawneetown, which was in sight, about seven miles ahead, informing the inhabitants that something would be "exhibited" in the dioramic line that evening, at their wharf-and so there was; for as the company approached the wharf with their boat, no doubt with high expectations of a good supper, they observed a large audience awaiting their arrival. But the exhibition turned out different from what was expected. The boat lodged on a ledge of rocks about half a cable's length from the shore. The men from the boat got out a line to the people on the wharf, who pulled with the same eagerness that the half starved company on board pushed and pried with their poles. But fate, regardless of the philosophy of action and reaction, as well as of the 
interests of the fine arts at Shawneetown, held the boat fast, and the audience went away without a sight of the paintings, and the artists to sleep again without a supper. That night the swells from a passing steamer lifted the boat from the rocks, and set it afloat down the river; and when those on board awoke in the morning, they found theinselves hard aground again, on the Cincinnati bar, eight miles below Shawneetown. The boat was got off with but little trouble, and they landed in a settlement. Here they were very liberal in their terms, as money was scarce, and they wanted to make sure of something to eat. A bushel of potatoes, a fowl, or a dozen of eggs, were good for an admission to their interesting exhibition. That night, after they got through exhibiting their paintings, they had a luxurious supper. Fasting so long appeared to have done Banvard some good, for it starved the fever out of him; he found, as we often do, that adversity has its blessings, and in a few days he was entirely well.

The adventurers continued on with their boat, stopping at the settlements along the shore, and "astonishing the natives" with their dioramas. The boat was not very large, and if the audience collected too much on one side, the water would intrude over their low gunwales into the exhibition room. This kept the company, by turns, in the unartist-like employment of pumping, to keep the boat from sinking. Sometimes the swells from a passing steamer would cause the water to rush through the cracks of the weather-boarding, and give the audience a bathing. Banvard says they made no extra charge for this part of the exhibition, although it was not mentioned in the programme.

Money being scarce, they were compelled to receive truck and trade for admissions, such as onions, potatoes, eggs, \&c., \&c. It was no unusual 
thing to see a family coming to witness the "show boat," the father with a bushel of potatoes, the mother with a fowl, and the children with a pumpkin a-piece, for their admission fees. On a certain night, while they were exhibiting, some rogue let the boat loose, and it drifted off several miles down the stream with the unconscious spectators, who were landed in a thick cane brake, about two miles below. They were obliged to make their way home as best they could.

At Plumb point the boat was attacked by a party of the Murrell robbers, a large organized banditti, who infested the country for miles around; and here Banvard came near losing his life. Several pistol shots were fired at him; but, being in the dark, none of them took effect, although several lodged in the deck of the boat, within a few inches of him. After a desperate resistance, during which one of the robbers was shot, the boat was rescned. During the encounter, one of the company received a severe wound in the arm from a bowie knife, but the rest escaped unhurt. Mr. Banvard continned with the boat until it arrived at the Grand Gulf, where he obtained a commission to paint some views. He had found the receipts of the floating expedition to be more potatoes than dimes-more eggs than dollars-so he sold out his interest and left.

After this, he engaged in painting at New Orleans, Natchez, and subsequently at Cincinnati and Louisville, and was liberally rewarded. Not content, however, he executed a very fine panorama of the city of Venice, and exhibited it in the west, with considerable success. He finally lost this painting by the sinking of a steamer, upon which it was being transported to the city of Nashville. Having accumulated, by his art, a little capital, we next find him as the proprietor of the St. Louis museum, which he had purchased. But here fate 
frowned again upon his efforts. He remained in St. Louis just long enough to lose all he had previously earned, and then left for Cincinnati, where he fared little better. He then procured a small boat and started down the Ohio river, without a dime, and living several days upon nuts, which he collected from the woods. His next stopping place was a small town, where he did some painting, and sold a revolving pistol, for which he had given $\$ 12$ in St. Louis, for \$25. With this capital he bought a larger boat, got some produce aboard, which he retailed out along shore-then sold his concern for $\$ 50$. Having now a little capital, the young artist made several very successful speculations, and managed to make, during this Quixotic expedition, several thousand dollars. With the capital thus accumulated, he commenced his grand project of painting the panorama of the Mississippi.

For this purpose, he procured a small skiff, and descended the river to make the necessary drawings, in the spring of 1840 , and the first sketch was made just before he became of age. Had he been aware, when he commenced the undertaking, of the vast amount of labor it required, he would have shrunk from the task in dismay-but, having commenced the work, he was determined to proceed, being spurred on to its completion, perhaps, by the doubts of some of his friends, to whom he communicated his project, as to its practicability, and by the assertions of some foreign writers, that "America had no artists commensurate with the grandeur and extent of her scenery." The idea of gain never entered his mind when he commenced the undertaking, but he was actuated by a patriotic and honorable ambition, that Arnerica should produce the largest painting in the world.

One of the greatest difficulties he encountered, was the preparatory labor he had to undergo, in making the necessary drawings. For this purpose 
he had to trarel thousands of miles alone in an open skiff, crossing and recrossing the rapid stream, in many places over two miles in breadth, to select proper points of sight from which to take his sketch; his hands became hardened with constantly plying the oar, and his skin as tawny as an Indian's, from exposure to the rays of the sun and the vicissitudes of the weather. He would be weeks together without speaking to a human being, having no other company than his rifle, which furnished him with his meat from the game of the woods or the fowls of the river. When the sun began to sink behind the lofty bluffs, and evening to approach, he would select some secluded sandy cove, overshadowed by the lofty cotton wood, draw out his skiff from the water, and repair to the woods to hunt his supper. Having killed his game, he would return, dress, cook, and from some fallen $\log$ would eat it with his biscuit, with no other beverage than the wholesome water of the noble river that glided by him. Having finished his lonely meal, he would roll himself in his blanket, creep under his frail skiff, which he turned over, to shield him from the night dews, and with his portfolio of drawings for his pillow, and the sand of the bar for his bed, would sleep soundly till the morning; when he would arise from his lowly couch, eat his breakfast before the rays of the rising sun had dispersed the humid mist from the surface of the river-then would start fresh to his task again. In this way he spent over four hundred days, making the preparatory drawings. Several nights during the time, he was compelled to creep from under his skiff where he slept, and sit all night on a log, and breast the pelting storm, through fear that the banks of the river would cave upon him, and to escape the falling trees. During this time, he pulled his little skiff more than two thousand miles. In the latter part of the summer he reached New Orleans. The yel- 
low fever was raging in the city, but unmindful of that, he made his drawing of the place. - The sun the while was so intensely hot, that his skin became so burnt that it peeled from off the back of his hands, and from his face. His eyes became inflamed by such constant and extraordinary efforts, from which unhappy effects he has not recovered to this day. His drawings completed, he erected a building at Louisville, Kentucky, to transfer them to the canvas. His object in painting his picture in the west, was to exhibit it to, and procure testimonials from, those who were best calculated to judge of its fidelity-the practical river men-and he has procured the names of nearly all the principal captains and pilots navigating the Mississippi, freely testifying to the correctness of the scenery.

Banvard was a self-taught artist - no-he had a teacher. He went not to Rome, indeed, to study the works of hands long since passed away; but he studied the omnipresent works of the One Great Living Master!-Nature was his teacher. Many a time, at the close of a lovely summer's day, after finishing his solitary evening meal, would he sit upon some lonely rock, near the margin of the noble river, when all was still, save the sweet chant of the feathered songsters of the adjacent forest, or the musical ripple of the eddying waters at his feet, and watch the majestic bluff as it gradually faded through the gray twilight from the face of day into the darker shades of night. Then would he turn and study the rising moon, as it peered above the opposite shore, ascending the deep blue ether high in the heavens above, casting its mellow light over the surrounding landscape, and gilding the smooth surface of the river with its silvery hue. It was then and there he studied Nature in its lonely grandeur, and seized those glowing moonlight scenes which now adorn his canvas, so vividly too 
as if painted with a pencil dipped in the silvery beams of the living moon itself.

During the time this undaunted young man was transferring his drawings to the canvas, he had to practise the most rigid economy, lest his money should give out before the picture was completed. He could not afford to hire a menial assistant to do the ordinary labor about his paint room; and when the light of day would recede from the canvas upon which he was at work, instead of taxing relaxation when the night came, he would be found grinding his colors or splitting his wood for the ensuing day. Still, with all these self-denials and privations, his last cent was expended long before his last sketch was transferred to his last piece of can vas. He then endeavored to get credit for a few pieces of this material, from the merchant of whom he had purchased the principal part for his painting, and with whom he had expended hundreds of dollars while speculating on the river, but in vain. Still, not discouraged, he laid his project aside for a time, and sought other work. Fortunately, he obtained a small job, to decorate regalia for a lodge of Odd Fellows, and with a light heart went cheerfully to work to earn the money which would purchase the material to complete his picture. With the avails he procured the needed canvas.

At last his great project is finished! The Mississippi is painted! and his country now boasts the largest painting in the world! But the trials of our persevering artist were not all passed. The history of the first exhibition of this wonderful production is curious, and furnishes another illustration of the necessity there is, never to despair. The gas company of Louisville, before they would put up fixtures for him, compelled him to deposit double the price of such fixtures in their bank. To raise this amount, he gave a piece of philosophical apparatus to a society in the city, provided they bought 
fifty tickets in advance. They agreed to this, as they desired the apparatus very much, as it was worth twice the amount they gave for the tickets. The city authorities also ordered him to pay a tax for exhibiting his work - a work of which they ought to have been proud, and which would not only reflect honor upon the city, but make it noted throughout the civilized world.

The first night he opened his great picture for exhibition in Louisville, not a single person thought it worth while to visit it. He received not a centthe night was rainy. The artist returned to his room with a sorrowful heart; he sat down upon a box and looked at the blank wall, where, but a few days before, with high spirits and a cheerful heart, he had put the finishing touch to his task of long years of toil and hope. His heart almost sank within him; but he did not despair. The next day he sallied out among the boatmen by the river, and gave them tickets; telling them they must see it; that it was their river he had painted. At night the boatmen came, and with them a few of their friends. When they saw the accuracy of the painting, they were delighted, and their wild enthusiasm was raised as one known object after another passed by them. The boatmen told the citizens it was a grand affair; that it was correctly delineated, and its accuracy could be relied upon. Finally, the public became convinced that the picture was really worth looking at, and then they rushed to see it by hundreds.

The great artist left the city and went to Boston, the Athens of America, where his beautiful painting was duly appreciated. The senate and house of representatives of Massachusetts honored the artist by passing a series of highly complimentary resolutions on his wonderful production. Admiring thousands upon thousands visited it, many coming hundreds of miles - from the remotest parts of New 


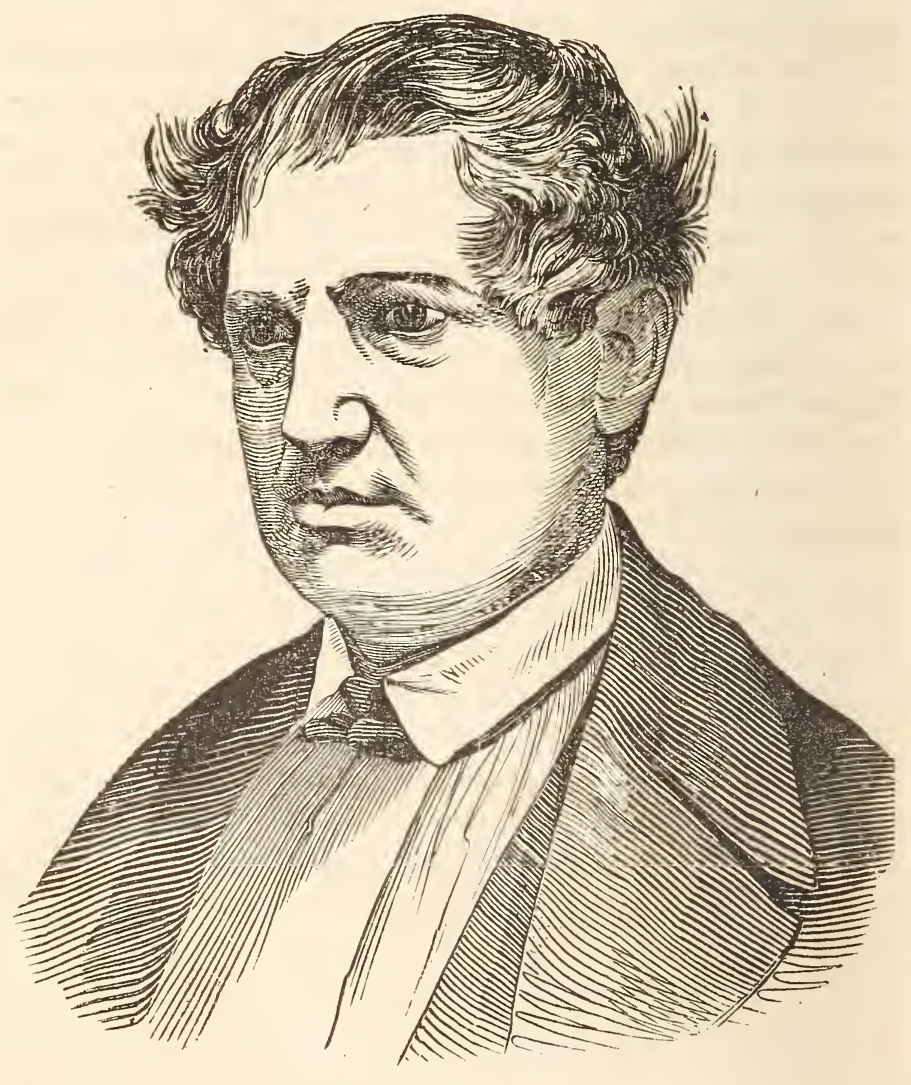

JAMES CONNER。 
England - to view this wonderful production. Indeed, so great was the desire to see it, that the rail road companies ran express trains from adjacent towns into the city for the accommodation of the eager throngs who wished to view the greatest achievement of individual enterprise upon record. And now our persevering young artist is justly reaping a golden harvest, having already made a fortune, realizing fifty thousand dollars during the first seven months' exhibition in Boston alone; and at the present time his great work is attracting large audiences in New York city.

The fame of the artist is his country's property. His genius and enterprise will be honored, as Gov. Briggs beautifully remarked, so long as the great Father of Waters, and its numerous tributaries, continue to pour their flowing tides into the great ocean.

\section{JAMES CONNOR.}

This person, who has been for many years at the head of a large type foundry in the city of New York, and who holds an honorable office in the county, was once a poor friendless, errand-boy in a printing office. Although, since his arrival at manhood, he has had many reverses, yet by struggling manfully he always came off victorious. With truth has it been said, that the early frowns of Fortune are the best security for her final smiles. 


\section{SAMUEL RATHBONE.}

A sketch of the Rathbone family, whose mem bers are found in Albany, New York, Buffalo, and other cities, would fill a volume. They are of Saxon origin, and their ancestors, men of great wealth and high standing, continued to reside in Liverpool, England, for more than three hundred years. Their American ancestor, a younger brother, named John Rathbone, emigrated to this country with the "pilgrim fathers," about the year 1620, and finally settled at Newport Rhode Island. His descendants are very numerous, and have settled in many portions of the United States.

The Rev. John Rathbone, father of the subject of this memoir, was born at Stonington, Connecticut, Jan. 26, 1729. He subsequently settled at Ashford, Windham county, in the same state. He was in the ministry 73 years, and died at Willington, August 2, 1826, aged 97 years. His eldest son, John Rathbone, a wealthy merchant of the state of New York, died there March 13, 1843, aged 91 years, leaving three sons and eight daughters. His son, John Rathbone, died at Albany, Aug. 13, 1842, aged 65 years, and was buried in the city of New York. He was also very wealthy.

Alanson Donglass, the grandson of the Rev. John Rathbone, above named, was a banker, and president of the Troy bank.

Samuel Rathbone, the subject of our sketch, is the youngest son of the Rev. John Rathbone. He was born at Stonington point, New London county, Connecticut, July 1, 1776. He married Miss Mary Turner, eldest daughter of Isaac Turner, Esq., a merchant of that county, on the 13th of April, 1800, by whom he has had ten children. 
In 1802 , he went into business as a merchant at Hartford, Connecticut. He subsequently removed to Charlemont, Franklin county, Massachusetts, where he was postmaster, and magistrate, until 1816. He afterwards conducted. his business in the cities of New York and Albany, for many years.

In June, 1841, he removed to Buffalo, his present residence.

A son, Henry A. Rathbone, is a banker in the city of New Orleans. Another son, Isaac T. Rathbone, is a member of the senior class at Yale college.

His eldest son, James, became a merchant in New York city, and died at Buffalo, Aug. 17, 1943, aged 41 years. Another son, Samuel, wa's educated at New Brunswick college, New Jersey, became a lawyer, and died in New York, Nov. 6, 1ऽ34, in his 25 th year.

The Rev. Valentine W. Rathbone, a brother of our subject, died at Bellingham, Massachusetts, May 12,1813, aged 52 years. Another brother, the Rev. David Rathbone, died at Lawrenceville, Pennsylvania, August 12, 1823, aged 60 years. They, as well as their father, the Rev. John Rathbone, were all clergymen of the baptist denomination. 


\section{ISAAC E. HOLMES.}

This gentleman, who has for so long a period been the popular representative in congress of the Charleston district of South Carolina, was born in that city on the 6th of April, 1796. He is a man of great energy, but is moved only by strong impulses. When fully aroused, a more complete transformation cannot be imagined. The eyes, which a moment before were almost without expression, now flash with the fires of the soul; and the man who appeared too indolent for the slightest exertion, enchains his audience by the beautiful imagery in which his sublime ideas are clothed. He is full of earnestness, and speaks as if he expected to convince.

As chairman of the committee on naval affairs, he has introduced many important measures relating to that branch of the service.

$\mathrm{Mr}$. Holmes is not one of those who, while they are extremely tenacious of their own rights, forget those of others. The following incident will serve as an illustration: Some sessions ago, during one of the "abolition scenes" in the house of representatives, a disposition was manifested to deprive Mr. Adams of his right to reply. Mr. Holmes, although opposed to the views of the ex-president, indignantly demanded that justice should be done. He succeeded. Lord Morpeth, who was upon the floor, approached Mr. Holmes and said: "That is magnanimous. That is the way we do things in our country!"

Mr. Holmes is married, and has we believe several children. 


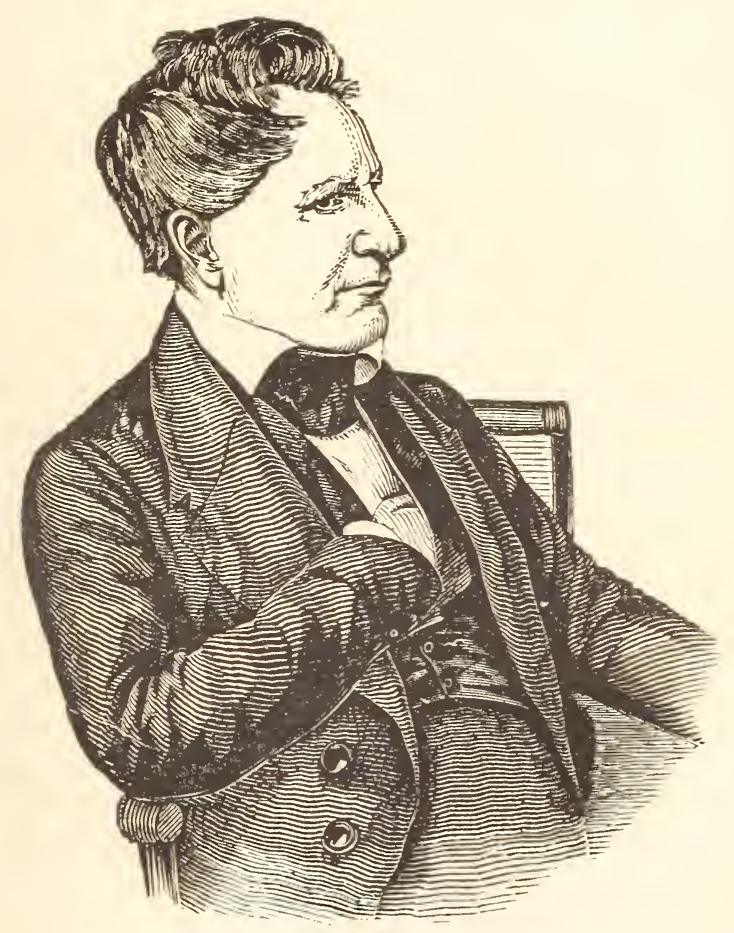

O E torms 



\section{ALANSON FISHER.}

This artist, a member of the National Academy of Design, was born at New Haven, Termont, on the $3 \mathrm{~d}$ of April, 180\%. In 1815, after a lingering illness, which reduced him to poverty, his father died, leaving a widow with eight children, to buffet with the storms of the world, a duty which she well performed. Alanson was the roungest child, and when only ten years of age, left home to procure his own living. After four years of hard labor on a farm, he went to New York city, for the purpose of learning a trade; but this being injurious to his health, he abandoned it, and in 1825 removed to Middlebury, Connecticut. He there engaged himself to a sign painter, and for whom he made several drawings. His employer praised them extravagantly; but, being poor, was unable to do much more. This mode of payment not being sufficiently substantial, he left and apprenticed himself to a machinist. This trade he was learning rapidly, when the failure of his employer once more threw him upon the world. He subsequently opened a small shop on his own account, but it proved a failure, and he lost his all. He was then compelled to return to the practical details of the trade. Having by this time had a plentiful share of the dark shades of life, he made that change which generally gives to its stern realities a lighter glow. In other words, in 1832 he married. But the little children soon began to grow up like olive branches around his table, so that his expenses soon began to exceed his means. In this dilemma, in spite of many discouragements, he commenced the business of portrait painting. For his first portrait he received only two dollars and a half; but he took heart, and by 
degrees, after a series of unexampled privations and sufferings he has now obtained no mean celebrity as a painter. In 1837, he was elected an associate of the National Academy of Design. He still resides in New York city.

\section{MORDECAI M. NOAH.}

In presenting an outline sketch of the cheerful physiognomy of this veteran editor, let not the reader suppose that we are so presumptuous as to attempt his history. To do justice to one who has not only been a military officer, a consul and a judge, but who has edited more newspapers than any other man in the Union, would require a volume.

The Major was born in the city of Philadelphia, on the 19th of July, 1785. He is, therefore, in his sixty-third year-but Time deals so leniently with those born to look on the bright side of things, that he has the appearance of a much younger man. While many of his editorial brethren have fallen, at the stern summons of death, the Major still lives and laughs, gathering the roses from among the thorns of life.

He has been so long accustomed to activity, that on the day when he shall resign the editorial chair, he may safely commence writing his epitaph.

He still resides in New York city, where we believe he publishes the Messenger.

$\mathrm{He}$ is an Israelite, and married a dark eyed daughter of Jerusalem, named Jackson. 


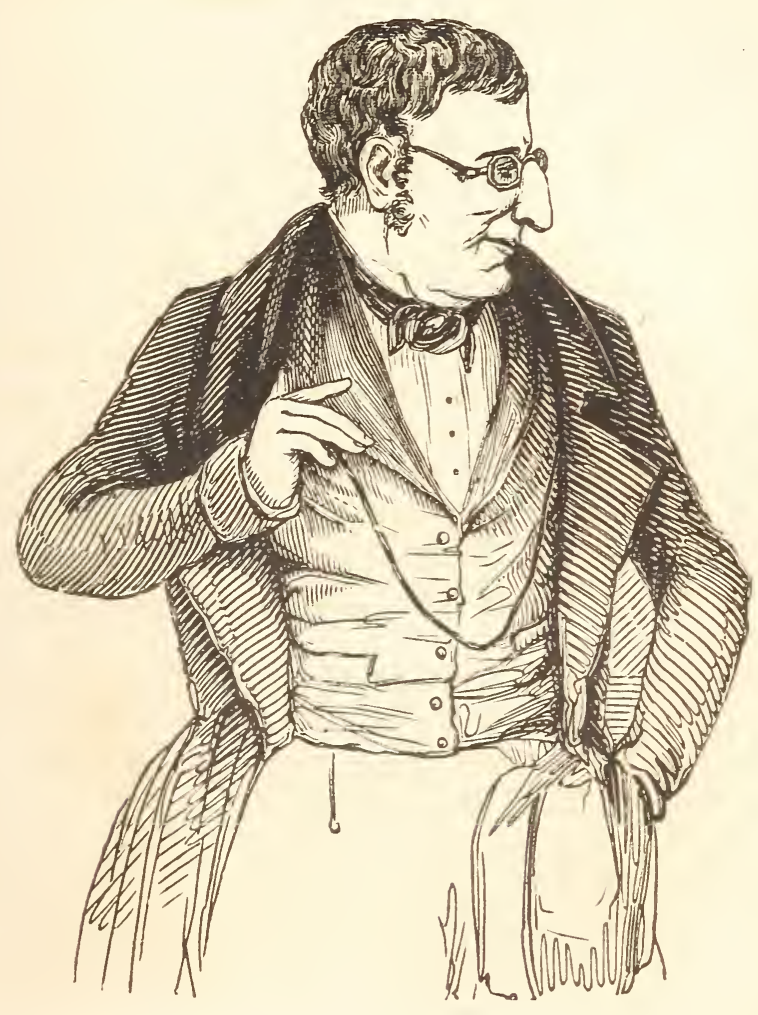

M. M. NOAH. 



\section{T. ADDISON RICHARDS.}

Mr. Richards was born in the city of London, in 1821. His father, the Rev. William Richards, left England with his family in 1831, and soon afterwards settled in Georgia, where he has since re sided.

During his school days, Addison's hours of recreation were passed in rambling in the fields and woods, after wild flowers, and in transferring to paper their forms of grace and beauty. In due time it was his ambition to seize the nobler attractions of nature in the ever varying landscape. His earliest production of any consequence, was a volume entitled, The American Artist, or Young Lady's Instructor in Flower Painting. It was highly complimented by the press, and a very large edition was sold. When this work appeared he was pursuing his studies, both literary and artistic, at Baltimore, with no other aids than what he was able to pick up from careful observation and from intercourse with fellow students, supporting himself meanwhile by industry in other channels. In 1839 he returned to the south, and opened a drawing school in Augusta, Georgia, where he taught with great success for the three following years. The seasons of vacation were passed in rambles through the picturesque regions of that state, in the collection of materials for a projected volume, illustrative of Georgia scenery. In these journeyings he was accompanied by his brother, W. C. Richards, Esq., to whose charge the editorship of the work was committed. It subsequently appeared under the title of Georgia Illustrated, and was liberally and extensively patronized. In addition to the beautiful sketches, many of the topographical articles were 
contributed by the subject of our notice. These pictures have since appeared in Graham's Magazine, and other periodicals. Notwithstanding its liberal patronage, the proprietors found the work too expensive to be continued with any hope of profit. The feature of landscape illustration was, however, retained in the Orion, a new work with which it was followed. This was an elegant monthly magazine of literature and art, of great typographical beauty. On the publication of the fourth volume, the Orion passed into other hands, and was soon afterward discontinued. Among the numerous literary contributions to its pages, by Addison, were The Trysting Rock, The Village Postmaster, Margaret Donaldson, Mauvaise Honte, Locomotion, etc. $\mathrm{He}$ has subsequently contributed to several other periodicals of high standing. But our purpose is to speak of him as an artist.

It was during the publication of the last volume of the Orion that he took up his abode in Charleston, South Carolina, as a portrait painter. He remained in that city, meeting with tolerable success, until the fall of 1844 , when he resolved to establish himself permanently in the city of New York, where he has since resided, laboring with increasing success and patronage.

His time is now devoted to landscape painting, in which department he is best known, and in which his reputation will ultimately lie. 


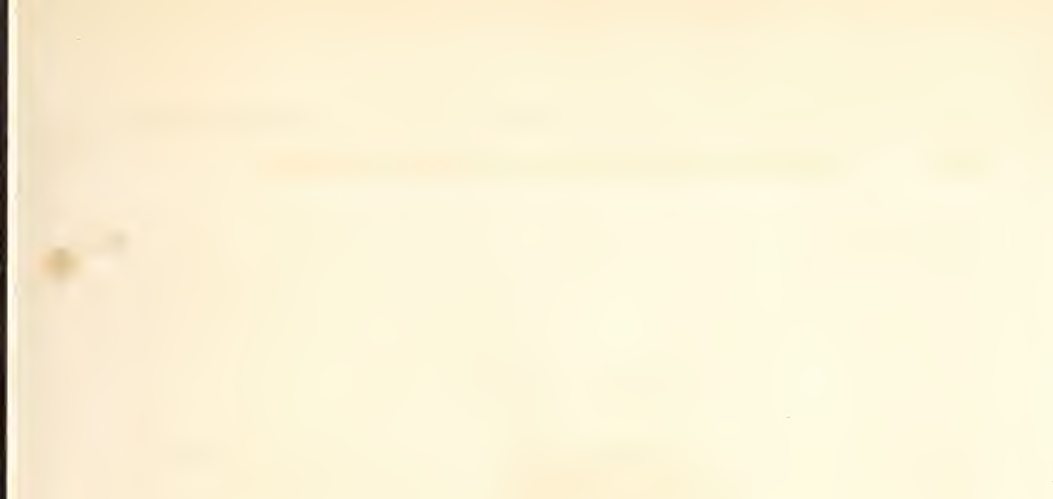
. 


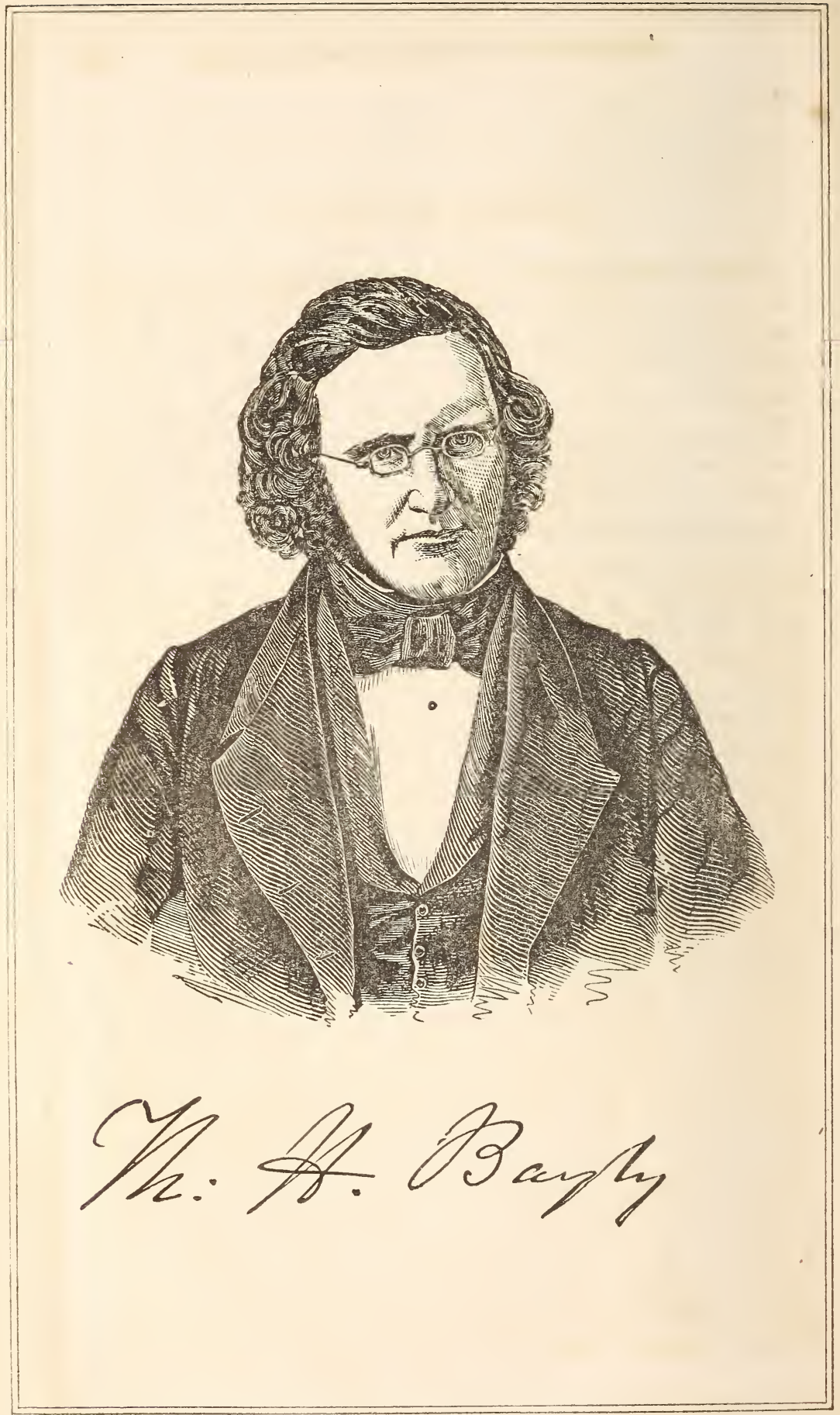




\section{THOMAS H. BAYLY.}

This distinguished gentleman was born in the county of Accomac, Virginia, on the 11th of December, 1810. He is the son of Col. T. M. Bayly, and on the maternal side, the grandson, of Gen. John Cropper, a brave officer of "the revolution. The ancestors of Judge Bayly, emigrated to this country from England in 1666, and settled on the estate on which the judge at present resides. Having graduated at the University of Virginia, where he studied law, our subject, in 1830, commenced the practice of his profession, in which he rapidly rose to distinction. In 1836 he was, by a large majority, elected by the legislature to fill the vacancy occasioned by the death of Gen. S. E. Parker. In 1841, Judge Upshur having been appointed secretary of the navy, Gen. Bayly was elected his successor by a very large majority of the legislature, many of whom were politically opposed to him. On resigning his seat in that body, the members of both houses, without distinction of party, gave him a grand entertainment at the Exchange hotel. He held his judicial office two years, to the entire satisfaction of the circuit, as was fully attested by the universal sentiment of regret on his resignation. In 1844, on the appointment of Mr. Wise as minister to Brazil, Mr. Bayly, at a great sacrifice of taste and interest, yielded to the urgent solicitations of his friends, and was, by a large majority over a whig opponent, elected to congress, in which body he has to the present time continued to add fresh laurels to those previously won. Distinguished for logical acumen and a forcible nervousness of delivery, he ranks among the very first class of debaters. With a refined classical taste, and the courtesy of 
the true Virginia gentleman, he commands the respect of all parties. In May, 1837, Gen. Bayly was united in marriage with Miss Evelyn May, a very amiable lady, the daughter of Judge John F. May, of Petersburg, Virginia. They have one daughter of whom they have every reason to be proud.

\section{OLIVER EVANS.}

Oliver Evans, the "Watt of America," was born at Newport, Delaware, in 1756. His parents were farmers. At the age of fourteen, Oliver was apprenticed to a.wagon maker. Even at that period, was manifested his ardent desire for knowledge. His master, an illiterate man, observing his apprentice employing his leisure evenings in study, through motives of parsimony, forbade him using candles; but young Evans was not to be discouraged, for collecting, at the close of each day, the shavings made from his work, he would take them to the chimney corner, and by their uncertain light, pursue his evening studies! Yet this poor boy subsequently invented many wonderful machines, among which was "Eructor Amphibolis," a steam carriage, being the first application, in America, of steam power to the propelling of land carriage. He died on the 21 st of April, 1819. 


\section{ELI WHITNEY.}

Seventy years ago, says the American Literary Magazine, in a country village of Massachusetts, the "meeting-house" bell was ringing on a Sunday morning; and grave-faced farmers, with their matronly wives and healthy children, were assembling for "meeting." Out from a plain parallelopiped of a house, before which stood a few stiff trees, came a family, dressed in their best suits in honor of the day, and proceeded with reverent steps to the house of God. The father did not, as was his custom, stop to fasten the front door of the house, through which they had issued; for one of his children, a boy of twelve, had complained of illness that morning, and had been left at home. One, however, who could have looked into the front room of that house, where sat the boy, would have seen the symptoms of illness disappearing fast, as the sound of the retreating footsteps of the family came less and less distinctly on his ear. Carefully watching from the window, he sees the last of the party pass from his sight; and then, with his face red with excitement and the consciousness of trespassing on forbidden grounds, he steals on tiptoe into the adjoining room. There hangs the object of his curiosity, to examine which he has feigned illness-his father's watch-a stout, old, silver timepiece, whose constant, careless tickings have long bewitched the boy's brain with the desire to understand their secret. The old watch seems to tick louder as the little fellow approaches it. He takes it down hastily from the nail where it hangs, opens it and peers in among the wheels which he has so longed to see. His eye, though unpractised, understands at a glance how cog moves $\operatorname{cog}$ and wheel turns wheel, 
from the barrel to the scapement, which now drops off the seconds less loudly as he holds the watch in his hand. But this is not enough; he must look more closely. He takes a little knife from his pocket, and handling it with the skill of an old workman, soon has the watch in pieces. All its delicate parts are lying before him, and the watch ticks no longer. Till this moment, in the eagerness of his curiosity, he has thought of nothing but the curious machine before him; but now, in the stillness of the room, the recollection of his stern father comes over his mind, and he almost shudders to think what he has done. "Meeting" must be half over; and, if he would escape detection, the watch must be put together uninjured before the family return. There is no time to be lost. Skilfully his little fingers arrange the intricate machinery, and put wheel after wheel into its place. But it is slow and nice work, especially for a boy's clumsy hands; and before it is done the sunshine in the room tells that the hour of noon has nearly arrived, and that the long sermon must be nearly finished. At last, however, the task is completed, just as the boy sees the foremost of the returning congregation; and with the joy of escaping detection, and the greater joy of understanding the machinery, he hangs the watch up in its place; and returning to the other room, takes his seat to await the arrival of the fami!y, with his hands full of the Bible and his head full of cog-wheels.

The boy was Eli Whitney the inventor of the invaluable cotton gin!

\section{NOTE.}

The notices of Gen. CASs and Col. Johnson arf unavoidably deferred until our next volume. 


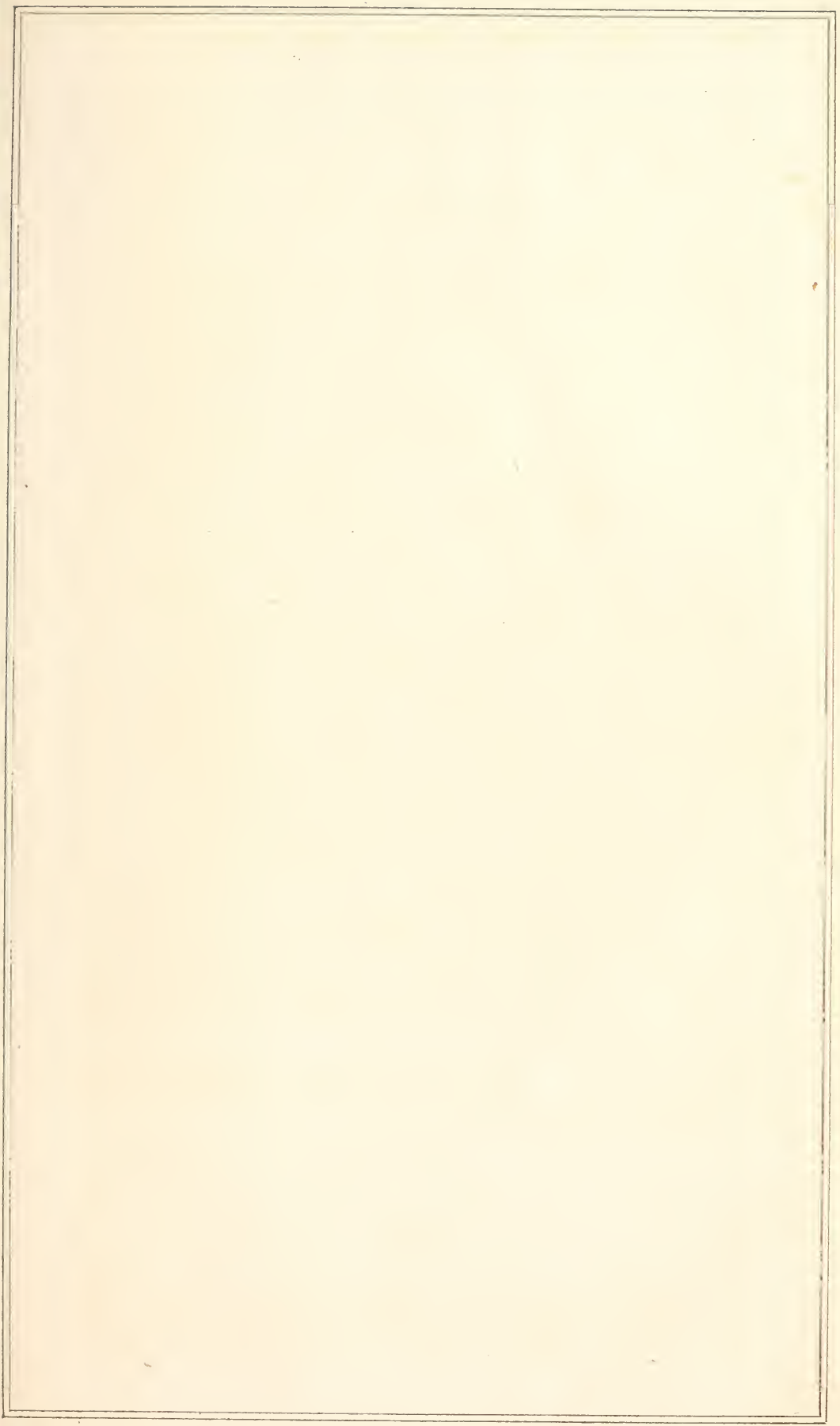





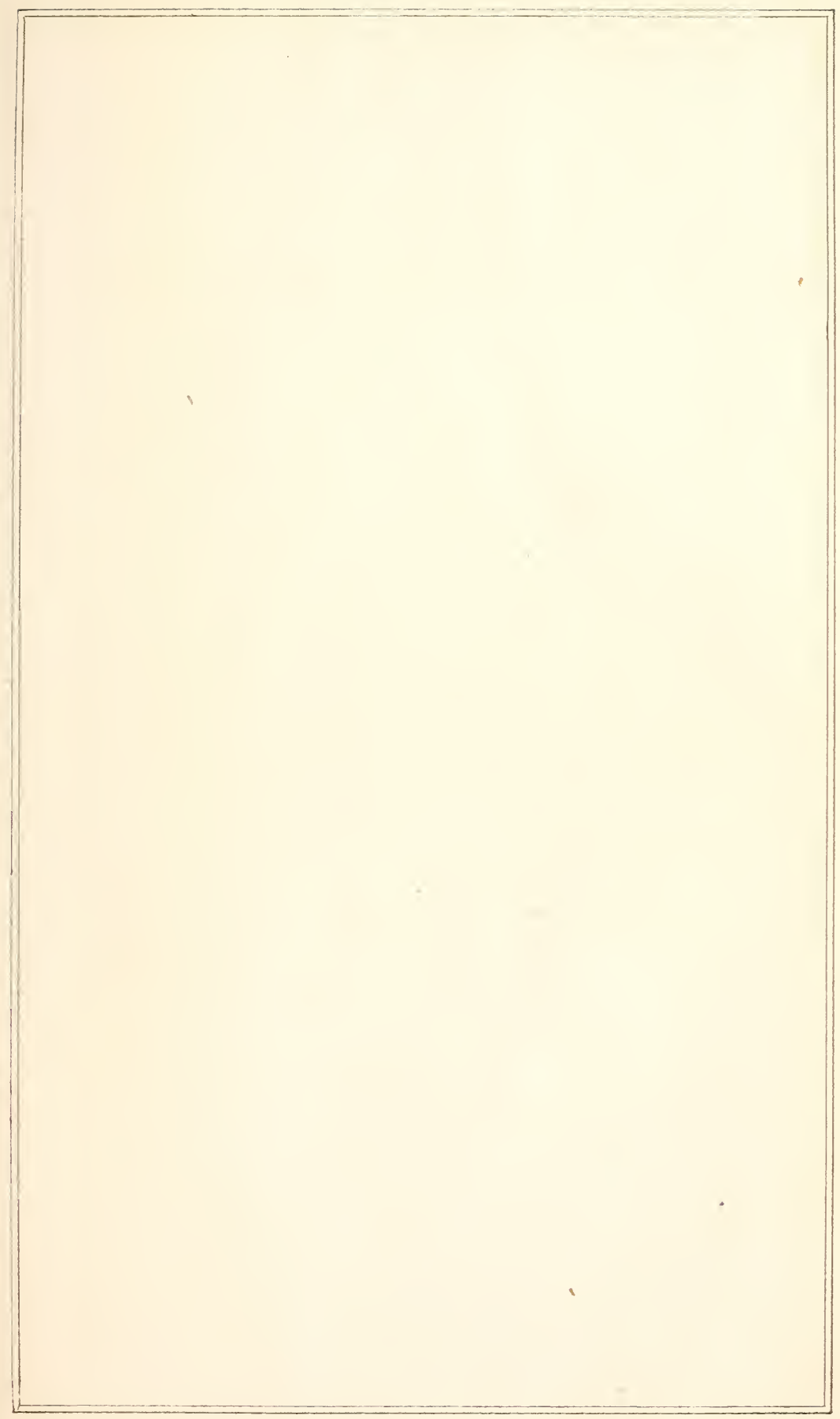





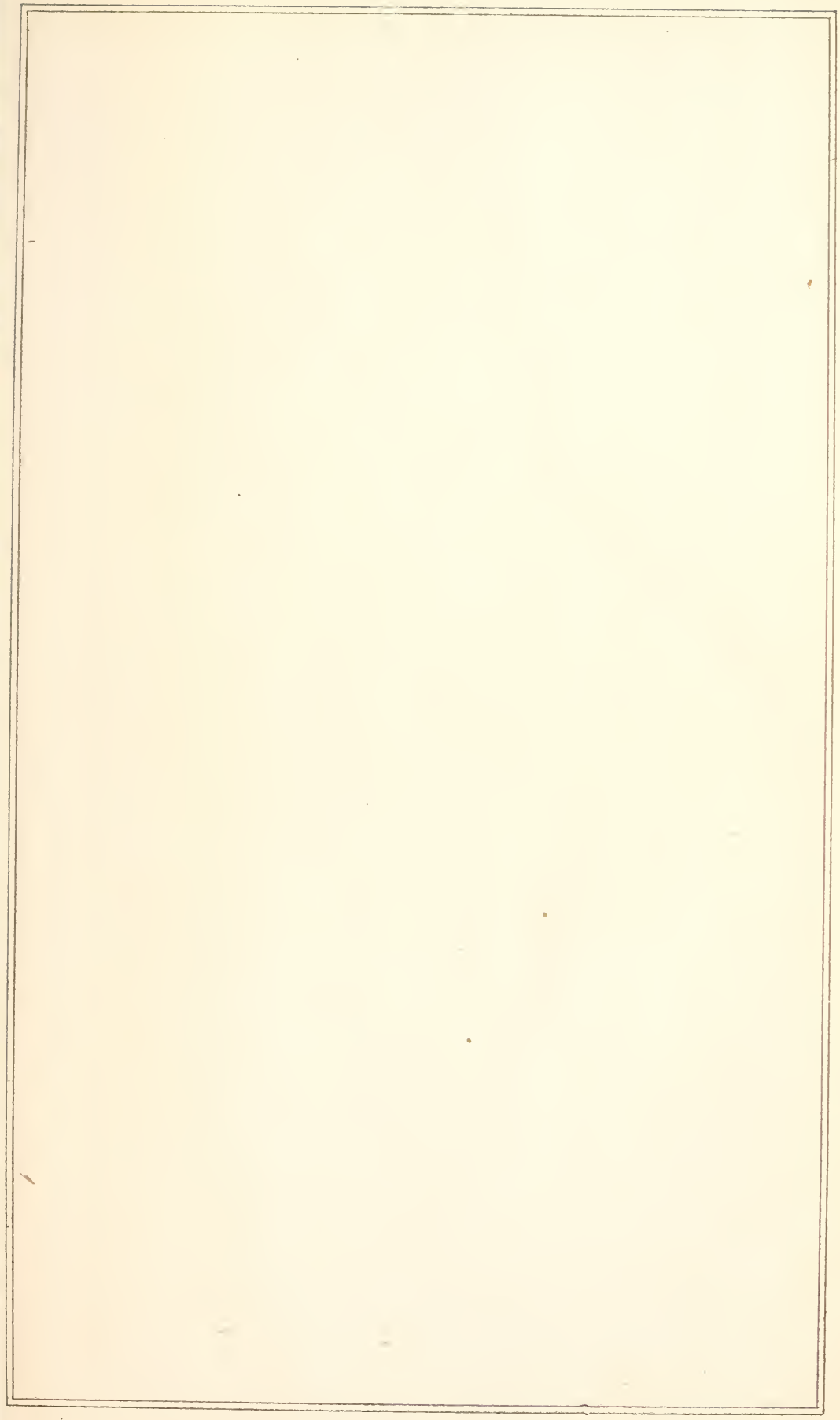




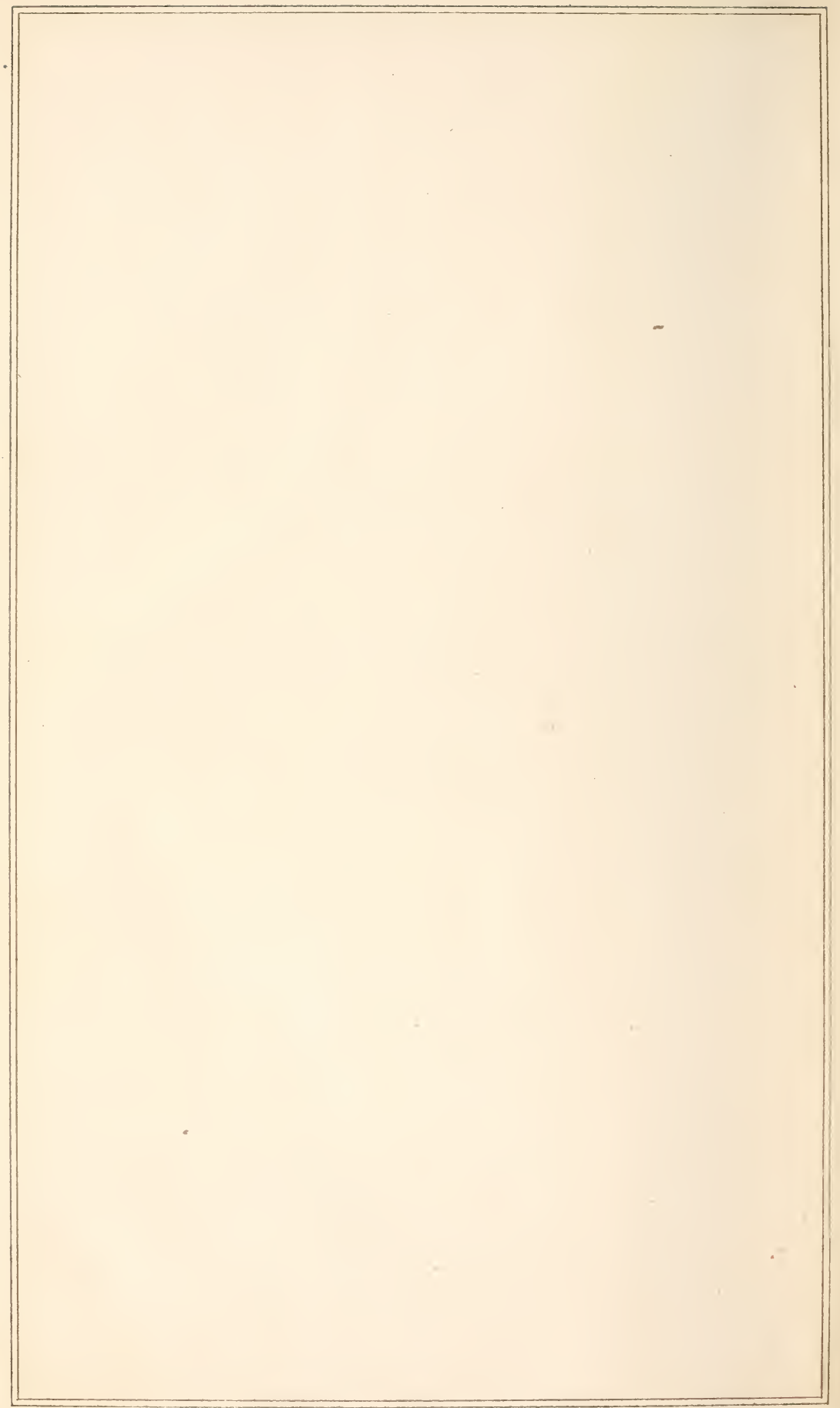




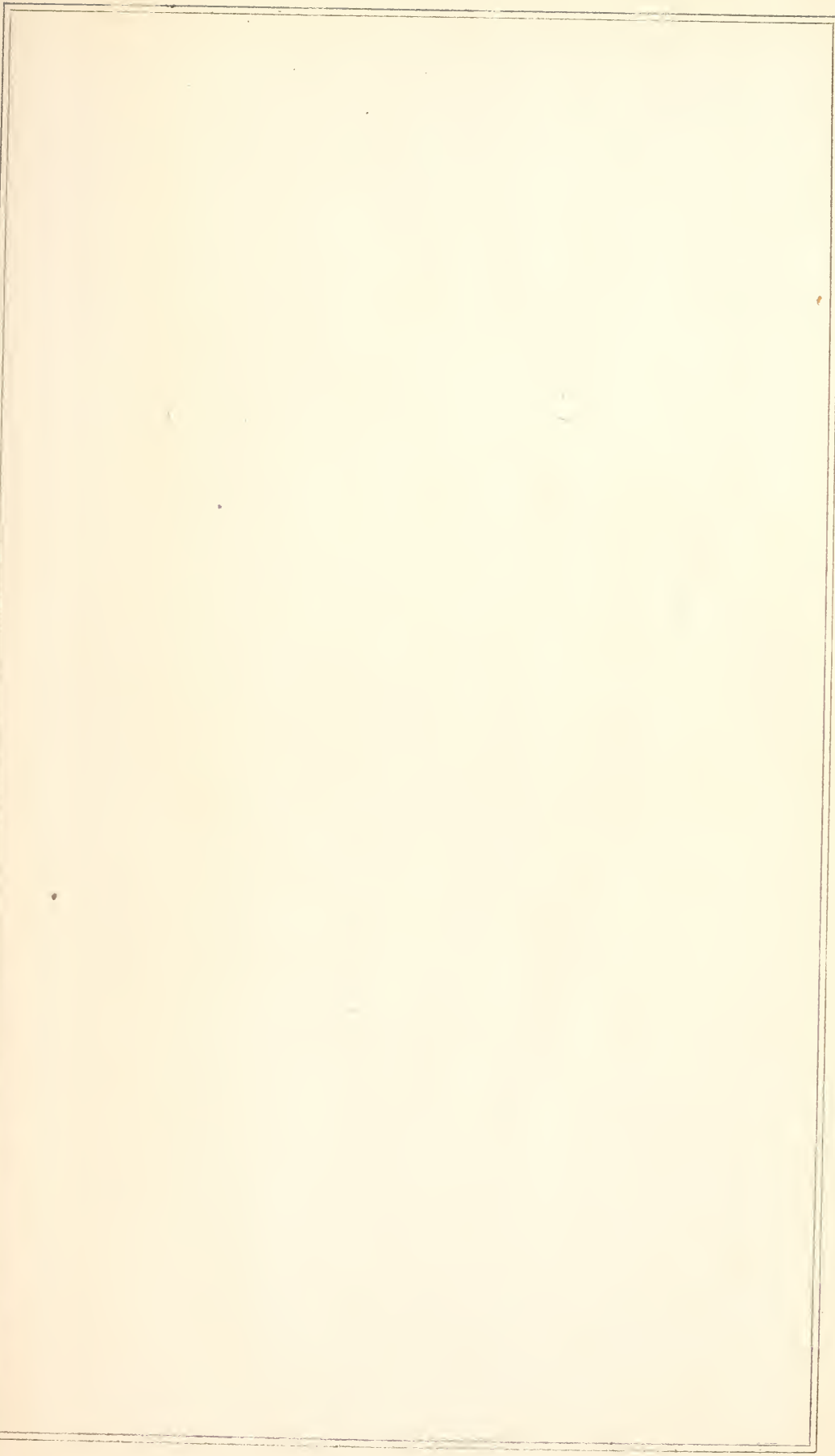




$H_{1}+40 a+62$

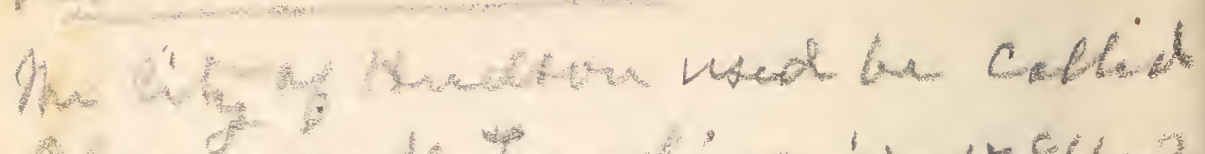

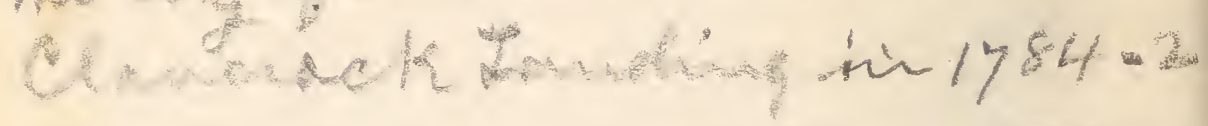

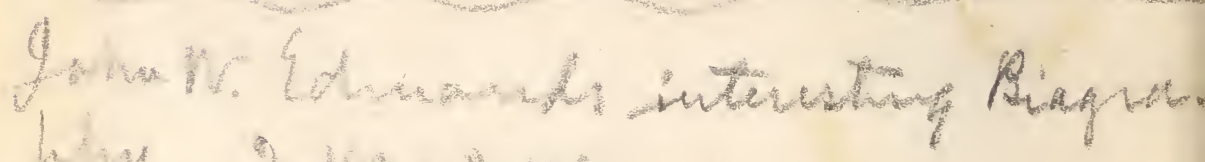

Why $240-246$

Sath Roat $24 y-2$ B

quintiang if y

$$
\text { twate turanh } 174
$$


र के ?

- 



SMITHSONIAN INSTITUTION LIBRARIES

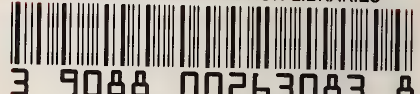

3 908в व0263083 \&

The Americag CT219.H94

The American biographical sketch book. 